$$
\text { UNIVERSIDADE DE SÃO PAULO }
$$

FACULDADE DE FILOSOFIA, LETRAS E CIÊNCIAS HUMANAS DEPARTAMENTO DE LETRAS CLÁSSICAS E VERNÁCULAS PROGRAMA DE PÓS-GRADUAÇÃO EM LETRAS CLÁSSICAS

O PANEGÍRICO, DE ISÓCRATES: TRADUÇÃO E COMENTÁRIO (versão corrigida) 
UNIVERSIDADE DE SÃO PAULO

FACULDADE DE FILOSOFIA, LETRAS E CIÊNCIAS HUMANAS DEPARTAMENTO DE LETRAS CLÁSSICAS E VERNÁCULAS PROGRAMA DE PÓS-GRADUAÇÃO EM LETRAS CLÁSSICAS

O PANEGÍRICO, DE ISÓCRATES: TRADUÇÃO E COMENTÁRIO (versão corrigida)

São Paulo 2014 
UNIVERSIDADE DE SÃO PAULO

FACULDADE DE FILOSOFIA, LETRAS E CIÊNCIAS HUMANAS

DEPARTAMENTO DE LETRAS CLÁSSICAS E VERNÁCULAS

PROGRAMA DE PÓS-GRADUAÇÃO EM LETRAS CLÁSSICAS

\section{O PANEGÍRICO, DE ISÓCRATES: TRADUÇÃO E COMENTÁRIO}

(versão corrigida)

André Rodrigues Bertacchi

Dissertação apresentada ao Programa de Pós-Graduação em Letras Clássicas da Faculdade de Filosofia, Letras e Ciências Humanas da Universidade de São Paulo para obtenção do título de Mestre em Letras Clássicas. Orientador: Prof. Dr. Adriano

Machado Ribeiro

São Paulo 
In memoriam patris 


\section{AGRADECIMENTOS}

Sou grato, em primeiro lugar, a minha família, que me apoiou durante todo o tempo de realização deste mestrado, fazendo o possível e o impossível para me ajudar. Nas dificuldades pelas quais passamos durante esses três últimos anos, não pude deixar de pensar que eu fui poupado das tarefas mais difíceis, para que pudesse, com o máximo de tranquilidade possível, dedicar-me a este mestrado; nada mais justo, portanto, que ele abra com o agradecimento à minha família.

Gostaria também de agradecer ao meu orientador, Prof. Adriano Machado Ribeiro; a ele devo muito mais que a competente (sem, contudo, nunca deixar de ser bem-humorada) orientação deste mestrado: foi nas suas aulas noturnas de sexta-feira, em meu último ano de graduação, que eu realmente comecei a aprender a língua grega e tive meu primeiro contato com Isócrates, tentando traduzir o Contra os Sofistas e o Elogio de Helena;

A minhas tias Maria Cecília, Regina e Stella, pelo amor e incentivo;

À CAPES, gostaria de agradecer pela bolsa a mim concedida, a qual foi-me de grande auxílio, após minha decisão de abandonar meu emprego para me dedicar integralmente à pesquisa;

Aos professores Marcos Sidnei Pagotto-Euzébio e Marcos Martinho dos Santos, pela leitura atenta e pelos valiosos comentários feitos em meu exame de qualificação e ainda mais por sua participação na minha defesa de mestrado, levantando problemas e questões que me auxiliaram ainda mais em enriquecer este trabalho. Também gostaria de agradecer aos professores Christian Werner, Paula da Cunha Corrêa, Paulo Martins e Adriano Scatolin, pelo auxílio prestado em diversas ocasiões;

A Eduardo Onishi e família, pelo incentivo e amizade;

A Tiago Jorge Tavares, pela camaradagem;

A todos meus alunos, sobretudo a Bárbara da Costa e Silva, Tiago Bentivoglio e Matheus Treuk, por terem-me ensinado mais do que eu a eles;

Aos meus colegas do PPG em Letras Clássicas, especialmente aos “isocráticos” Júlio de Figueiredo Lopes e Ticiano Curvelo, que, tendo me antecedido no estudo de Isócrates, forneceram-me valiosas 
lições e subsídios bibliográficos para a realização da minha pesquisa. A Pedro Baroni Schmidt, agradeço a simpatia e o entusiasmo pelo estudo das línguas clássicas, e pela dedicação com que exerceu o cargo de representante discente, guiando o caminho para mim e o Ticiano, que o sucedemos nessa tarefa. Merecem menção especial ainda minha colega Caroline Evangelista Lopes, não somente pela seriedade de seu trabalho, mas pela gentileza com que sempre me socorreu nos muitos momentos de apuro, e também Artur Costrino, amigo desde a graduação em latim e que me enviou de Londres um texto de que eu necessitava para a dissertação;

Je suis obligé aussi envers tous les amis que j'ai rencontrés en France, pendant mon sejour à l'École Normale Supérieure de Paris, parce qu'ils ont contribué à faire cette expérience inoubliable pour moi. Je dois surtout remercier, pour la gentillesse et amitié avec lesquelles ils m'ont reçu: Sylvain Cabanacq, Délphine Rodolphe, Alexandra Fricker, Clotilde Nouët et Émilie Douguet. Lena Smirnova, Dinara Podgornova, Lin Shumai, Iztván Fazakas, Anastasia Stasienko et Flora Mangini figurent parmi les plus intélligentes, aimables et amusantes connaissances que j'ai faites à l'occasion, et je remercie chacun d'eux pour les moments que nous avons passés ensemble et pour les maintes choses qu'ils m'ont apprises. Merci! 


\title{
RESUMO
}

Este trabalho propõe a tradução do discurso Panegírico, de autoria do ateniense Isócrates. A versão vem acompanhada de notas, que visam a fornecer um breve comentário das passagens mais importantes do texto. Um estudo introdutório, cujo primeiro capítulo pretende discutir algumas questões propostas pelo texto, tratando de sua composição, do tratamento dos fatos históricos e um breve relato das principais interpretações modernas do Panegírico. O capítulo seguinte aborda o problema dos bárbaros no Panegírico e como o retrato de Isócrates dos povos não gregos visa a reforçar as propostas feitas pelo autor em seu texto. Na parte final do estudo, examina-se a relação desse texto com obras precedentes tratando das mesmas questões que o Panegírico.

Palavras-chave: Isócrates; Panegírico; prosa grega do IV século a.C.

\begin{abstract}
This work proposes to translate the Panegyricus, a speech by the Athenian Isocrates. Endnotes have been added, in order to comment the most important passages in the text. In addition, an introductory study is included to clarify the some points of the text, such as the problems posed by the composition of the text, its treatment of the historical facts and a brief review of the main modern interpretations of the Panegyricus. The next chapter discusses the role which the barbarians play in the Panegyricus and how Isocrates' portrait of the non-Greek peoples serves the propositions advanced by the author in his text. The final part of the study examines the relation of the Panegyricus with texts treating the same questions.

Key-words: Isocrates; Panegyricus; Greek prose of the IV century BC.
\end{abstract}




\section{SUMÁRIO}

\section{Estudo introdutório}

1 - Do Panegírico $\quad 8$

2 - Gregos e bárbaros no Panegírico 36

3 - O Panegírico e os discursos Olímpicos 44

Tradução

Prefácio à tradução $\quad 58$

$\begin{array}{ll}\text { Texto } & 59\end{array}$

$\begin{array}{ll}\text { Tradução } & 93\end{array}$

$\begin{array}{ll}\text { Notas à tradução } & 129\end{array}$

$\begin{array}{ll}\text { Bibliografia } & 148\end{array}$ 


\section{1 - Do Panegírico}

\section{a) Sobre a composição}

Quanto à data em que foi escrito o Panegírico, comentadores, a partir do séc. XIX, defenderam que a apresentação do discurso ao público deu-se no verão de 380 a.C. ${ }^{1}$ A evidência em favor desse juízo, segundo eles, é a menção ao cerco de Flionta pelos espartanos (126), que, iniciado em 380 a.C. e tendo final no ano seguinte, é referido por Isócrates como ainda em curso. De acordo com esse argumento, portanto, o Panegírico situar-se-ia cronologicamente no intervalo de 380-379 a.C., mesmo período em que ocorreu a centésima edição dos Jogos Olímpicos. Com efeito, um panegírico, como indicado em seu título, ${ }^{2}$ é um discurso pensado para ser pronunciado em uma panegíria, ${ }^{3}$ e os comentadores consideraram que, para determinar o momento de sua primeira apresentação ao público, bastava encontrar a panegíria que coincidisse com a data acima indicada.

Naturalmente, tal conclusão implicava que o Panegírico tivesse sido pronunciado in loco por Isócrates, ${ }^{4}$ ou ao menos que suas primeiras cópias em livro tivessem sido divulgadas durante o festival, ${ }^{5}$ algo que nossa ignorância quanto às circunstâncias de publicação dos discursos isocráticos

\footnotetext{
${ }^{1}$ Wilamowitz-Moellendorff: 1985, vol. II, p. 380; Jebb: 1876, vol. II, p. 150; Mathieu: 1956, vol. II, p. 5.

${ }^{2}$ Não há dúvidas de que esse título foi atribuído pelo próprio autor, e não por algum gramático antigo ou copista durante a transmissão manuscrita (como talvez seja o caso do Sobre a Paz, assim denominado nos manuscritos

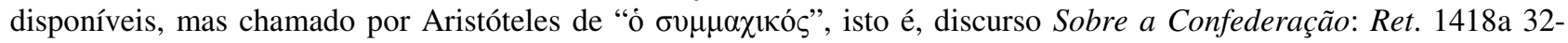

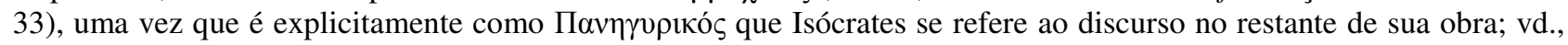
por exemplo, o Filipe $(9,84)$ ou o Panatenaico (172).

${ }^{3}$ As panegírias eram os grandes festivais pan-helênicos, a exemplo dos Jogos Olímpicos. Para Maiores detalhes, vd. 4043 deste estudo.

${ }^{4}$ Wilamowitz, provavelmente seguindo o juízo de alguns gramáticos antigos (Fláv. Filóst. Vida dos Sof. I, 17, 2; Men. Sobre os Disc. Epid. 391, 4; Pseudo-Plut. Vida de Isóc. 387b), considerava que Isócrates realmente pronunciara o Panegírico para a multidão reunida em Olímpia, embora o tivesse feito a contragosto ("Isokrates wollte den seinen [panegyrikos] freilich nicht selbst halten, aber er tat doch so...": 1985, vol. II, p. 380). Tal hipótese se originava da concepção muito particular de política que o comentador atribuía a Isócrates e a seu discurso, classificado como "escrito político de ocasião" ("politische Gelegenheitsschrift". ibid., p. 384), isto é, voltado a alcançar, tal como as falas dos oradores em assembleia, um objetivo político momentâneo, no caso, a criação de uma nova aliança marítima das poleis gregas sob o comando de Atenas (vd. a última seção deste capítulo, p. 30-35).

${ }^{5}$ Blass refere-se a essa hipótese: "Pode-se [...] imaginar que Isócrates intencionalmente publicou seu discurso durante o período de um festival olímpico - o ano 380, no qual ele provavelmente foi publicado, era ano de Olimpíada - e que, em Olímpia, ele imediatamente difundiu exemplares do discurso." ("Man kann [...] sich denken, dass Isokrates mit Absicht seine Rede zur Zeit einer olympischen Festfeier veröffentlichte - das Jahr 380, in welchem sie wahrscheinlich erschien, ist ein Olympiadenjahr - und dass er in Olympia alsbald Exemplare verbreiten liess”. 1874, vol. II, p. 229).
} 
nos impede de afirmar. É questionável, portanto, o uso que esses primeiros comentadores modernos fizeram da informação cronológica fornecida pelo parágrafo 126, ao associá-la imediatamente a um momento específico em que o Panegírico teria sido apresentado a seu público, ignorando uma característica essencial da obra de Isócrates, que é o fato de ela ter sido composta visando à leitura. Pois, além de passagens presentes nos discursos isocráticos explicitando que sua composição se dera por meio da escrita, quando Isócrates se refere especificamente ao Panegírico no restante de suas obras, muitas vezes o faz com alguma expressão que evidencia seu caráter escrito, ${ }^{6}$ fornecendo uma indicação a seus leitores de que o discurso se diferia daqueles que por acaso se ouvissem em um evento público.

Pouco difere em substância dessa primeira hipótese, ademais, a consideração de que o autor teria reservado a publicação do texto para os dias em que aconteciam os Jogos Olímpicos de 380 a.C., pois ela ignora as especificidades da publicação de manuscritos na antiguidade, a qual certamente não se dava de maneira uniforme em um momento preciso do tempo, como talvez pudesse acontecer com o livro impresso. É nos atentando à dimensão escrita da obra isocrática, pois, e de como os manuscritos eram divulgados na antiguidade, que tentaremos examinar a possível indicação de uma data, tal como fornecida pelo parágrafo 126 do discurso.

Se considerarmos outros autores contemporâneos, não podemos dizer que suas práticas diferissem da de Isócrates. Os discursos supérstites de Demóstenes, Ésquines ou Andócides, por exemplo, dificilmente podem ser pensados como registros fiéis das falas por eles pronunciadas em algum espaço público: mesmo que seus textos se apresentassem como discursos anteriormente declamados, sua fixação pela escrita não excluía que pudessem ser feitas adaptações ao novo meio ou mesmo revisões, corrigindo eventuais problemas que impediram a aceitação das propostas feitas pelo orador. Sendo assim, para esses autores, a escrita incidia sobre o discurso apresentado

Mas poderíamos mesmo acreditar que Isócrates tivesse redigido de antemão o Panegírico e, já com o discurso completo, o fornecesse aos vendedores de livros, para que dele fizessem cópias e assim o comercializassem durante os jogos? Parece absurdo, mas é o que somos obrigados a admitir, se concordamos com a afirmação de que a publicação do Panegírico se deu em um evento específico.

${ }^{6}$ Ant. 55, 57, 87; Fil. 11, 85; Ep. Fil. II 6. 
oralmente, instrumento de atuação política na Atenas democrática, a fim de prolongar as posições por ele adotadas e estender seu efeito para além das assembleias e tribunais onde primeiro foram reveladas ao público. ${ }^{7}$

Em Isócrates, por outro lado, esse procedimento tornava-se mais claro, uma vez que o autor afirmava nunca haver publicamente pronunciado seus discursos, mas, ao contrário, que toda sua obra consistia de textos escritos, ${ }^{8}$ os quais visavam exclusivamente à leitura, mesmo quando tais textos mimetizavam a fala dos oradores em um espaço público. ${ }^{9}$ Mas essa escolha do autor pela escrita para tratar de assuntos de "interesse da Grécia, de reis e das poleis"10 tornou-se um obstáculo à boa compreensão da obra isocrática para os comentadores modernos.

$\mathrm{Na}$ Atenas democrática, com efeito, que abria seus espaços de governo para todos os cidadãos, a fala era o principal meio de atuação política, e as decisões sobre a administração da polis deveriam necessariamente passar pela sanção nas assembleias públicas, onde poderiam ser defendidas ou atacadas por qualquer um dos participantes. Nessas condições, o alcance de um texto escrito seria bastante reduzido, ainda que a escrita tivesse um papel fundamental na organização das

\footnotetext{
${ }^{7}$ É provável que, ao divulgarem um livro supostamente contendo o texto de um discurso por eles declamado, esses autores não fizessem uma transcrição do que anteriormente eles haviam falado. Nesses casos, não se tratava apenas de corrigir eventuais falhas que houvessem comprometido o sucesso de uma primeira apresentação do discurso à audiência, mas pode-se mesmo supor a inexistência prévia de texto que contivesse as palavras pronunciadas na ocasião: segundo o testemunho de Alcidamante (Contra os Escritores de Discursos Escritos), seria de pouca utilidade ao orador ter um roteiro detalhado de tudo o que seria dito, não somente pela dificuldade em se memorizar tamanha quantidade de informação (sendo preferível preparar de antemão apenas os argumentos a serem utilizados na ocasião, e não decorar palavra por palavra o que se pretendia dizer: 18-21), mas sobretudo porque o orador poderia adaptar o discurso à resposta da audiência (22-23). Tal prática opunha-se, talvez, à logografia, pois o discurso, composto por um profissional, deveria ser decorado por aqueles que encomendavam o discurso, que depois o pronunciariam diante do público (pode-se pensar que Platão, no Fedro, alude a tal prática, quando retrata o personagem título do diálogo a portar um livro contendo o discurso previamente recitado por Lísias, conhecido logógrafo, para que pudesse decorá-lo); mesmo aí, porém, não podemos ter certeza de que o discurso fosse recitado tal como o logógrafo o ensinara a seu cliente, sendo possíveis mudanças de última hora, também de forma a melhor adaptar o texto à recepção pela audiência. ${ }^{8}$ Panat. 12; Fil. 81-82 e 25-26; Ep. a Dion. (I) 2, 9-10; Ep. Mit. (VIII) 7.

${ }^{9}$ Uma diferença importante entre a escrita a fala como veículos de propostas políticas era, particularmente na Atenas democrática, a questão dos oponentes. Ao falar nas assembleias e, principalmente, nos tribunais, um cidadão podia ter a certeza de que seus argumentos seriam questionados por outro orador, a defender teses contrárias. Na escrita, no entanto, mesmo que supostamente reproduzindo a fala pronunciada em uma ocasião anterior, os oradores poderiam reformular negativamente a atuação de um adversário em um debate público.

${ }^{10}$ Panat. 11: “...já que falhei na atividade política, refugiei-me em filosofar e trabalhar e escrever o que pensava, escolhendo tratar não de coisas de pouca importância nem dos contratos privados nem das coisas que alguns outros

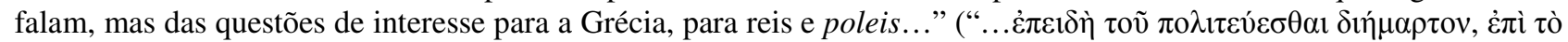

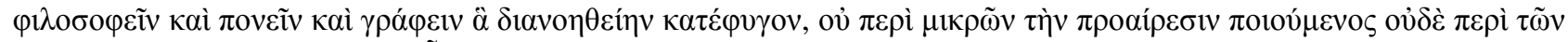

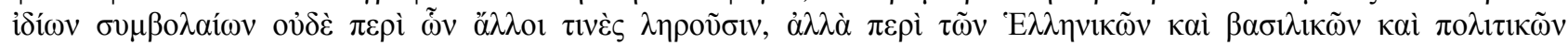
$\pi \rho \alpha \gamma \mu \alpha \dot{\tau} \omega v \ldots .$.$) .$
} 
poleis, sobretudo ao permitir a fixação das leis, geralmente inscritas em pedra, para que fossem vistas por todos.

Assim, nas passagens em que o autor justifica sua maneira muito particular de participação na vida pública, ele explica que a escolha da escrita não foi voluntária, mas consequência de não possuir uma voz suficientemente forte nem bastante ousadia para encarar as grandes multidões presentes nas assembleias e tribunais. ${ }^{11}$ Não temos meios de confirmar a veracidade dessas afirmações, mas parece claro que elas fazem parte de uma estratégia de Isócrates para valorizar seus textos como peças tratando das questões públicas, em detrimento da fala, retratada como causa das más condutas na política da Atenas contemporânea. ${ }^{12} \mathrm{O}$ modo como Isócrates retrata os oradores nesses trechos, com efeito, guarda evidentes semelhanças com as censuras à política ateniense feitas por autores contemporâneos.

O quadro da oratória ateniense à época encontrado na Constituição de Atenas de Aristóteles, por exemplo, apresenta uma forte reprovação dos discursos apresentados pelos oradores em assembleia, destacando os gritos e as ofensas, lançados contra seus oponentes, com que eles pretendiam chamar a atenção da audiência para suas propostas. ${ }^{13}$ Da mesma forma, Isócrates diz recusar-se a falar nas assembleias, por não ter "a ousadia capaz de ser útil diante do vulgo, nem sofrer os abusos e insultos junto aos que vêm e vão das assembleias". ${ }^{14}$ Heilbrunn, com efeito,

\footnotetext{
${ }^{11}$ Fil. 81: “...eu, mais do que todos os cidadãos, nasci com uma natureza inapta à política...” (“...દ่

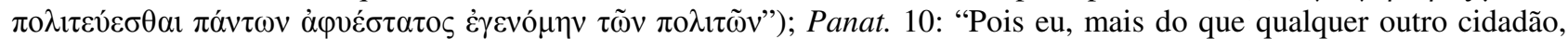
nasci carente das duas coisas que têm o maior poder entre nós [atenienses]: uma voz adequada e atrevimento" ("Ov́t $\omega$

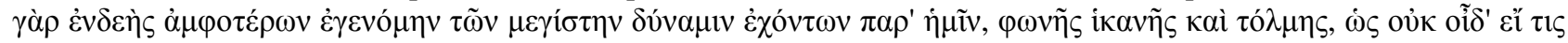

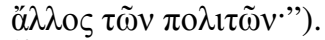

${ }^{12}$ A democracia ateniense se caracterizava por uma grande abertura política, a possibilitar a todos os cidadãos o direito de participação nas assembleias e tribunais. Ao mesmo tempo, contudo, homens treinados na composição de discursos se valessem de sua habilidade para persuadir a audiência e conseguir vantagens pessoais.

${ }^{13}$ Const. Aten. 28, 3: "Após Péricles morrer, [...] liderou o povo Cleão, filho de Clianeto, que parece ter sido o que mais corrompeu o povo com a impetuosidade de sua fala, e foi o primeiro a falar sobre a tribuna gritando, lançando

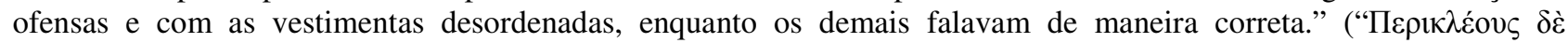

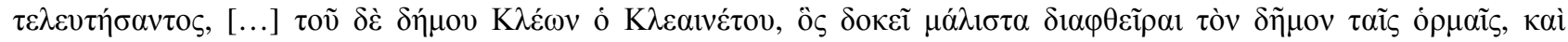

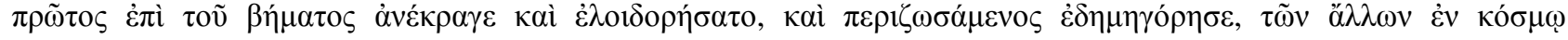
$\lambda \varepsilon \gamma o \dot{v} \tau \omega v . ")$.

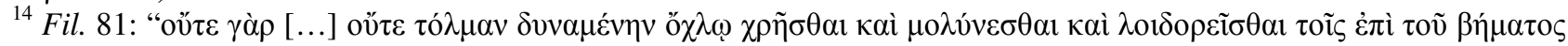
$\kappa \cup \lambda ı v \delta o v \mu \varepsilon ́ v o เ \varsigma . . . "$. Deve-se ainda notar que, embora Isócrates afirme não partilhar da ousadia dos oradores, devido a sua condição única como professor, ele afirma falar "mais asperamente" ("thrasyteron") que qualquer general orador ou homem público em geral.
} 
demonstrara que a ousadia ("tolma") necessária a se dirigir a rude audiência das assembleias era qualificada nos escritos de Isócrates como um vício próprio à democracia, revelando a oposição do autor ao sistema político de sua polis. ${ }^{15}$

Essa recusa dos espaços públicos de deliberação em Atenas é um topos, de emprego comum entre autores de período. Donald Lateiner, por exemplo, defende que a passagem inicial do Contra Eratóstenes (XII), quando Lísias diz nunca antes ter falado em uma assembleia, não se devia a sua condição de meteco em Atenas ou ao exercício da logografia, como defendido por outros estudiosos; tratava-se, segundo o comentador, de uma estratégia empregada por Lísias para afastar de si a imagem de indivíduo litigante, que frequenta os espaços públicos para obter vantagens pessoais. ${ }^{16-17}$ Longe de constituir um caso excepcional, contudo, a declaração de Lísias de nunca ter frequentado um tribunal encontra eco em muitos dos exemplares do corpus de oradores áticos. Platão, com efeito, também usa desse expediente em seu fictício discurso de defesa de Sócrates; mais surpreendente, porém, é encontrar

Em contrapartida, as desvantagens de uma voz fraca tornam-se um símbolo de virtude, pois, ao mesmo tempo em que proporciona o pretenso afastamento do corrompido espaço da oratória

\footnotetext{
${ }^{15}$ A associação da democracia com a tolma é particularmente perceptível no Nícocles 21, em que, tendo assumido a voz do tirano de Salamis, o autor procede a uma comparação da monarquia com outras formas de governo: "Homens nessa forma de governo se ocupam dos assuntos públicos como algo alheio, enquanto os monarcas os tratam como questões de interesse particular. E os democratas se servem dos conselhos mais ousados, enquanto os reis escolhem, dentre todos, os mais sensatos. E, nas outras formas de governo, honram-se os que sabem falar em meio à multidão, mas, nas

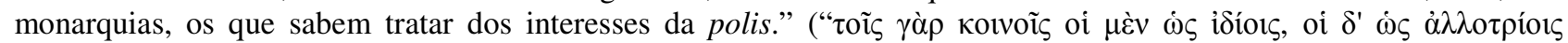

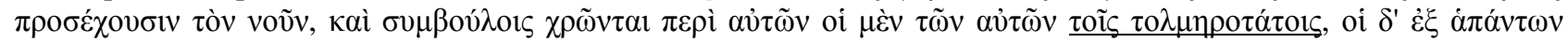

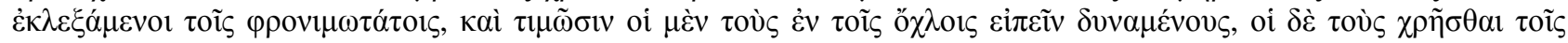

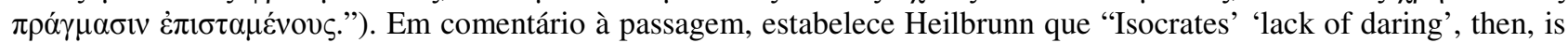
not so much an admission of weakness as it is an accusation of the Athenian democracy. [...] The propensity of democracies to employ 'daring' rather than 'prudent' citizens is a serious flaw; daring is a vice rather than an ornament of democracy. The criticism falls into a conservative tradition which finds Athenian democracy wanting because of its recklessness and lack of restraint, and champions 'moderate' government..." (1975, p. 157-58).

${ }^{16}$ Lateiner: 1982, p. 4 "Eagerness for litigation was a charge constantly brought against one's prosecutor. The man who is sophron and dikaios, moderate and just, will avoid such entanglements whenever possible...".

${ }^{17}$ Essas eram censuras lançadas por críticos da democracia contra a forma de governo de Atenas como um todo, embora estivessem estritamente associadas com os tribunais, onde oradores treinados conseguiam convencer os juízes a prejudicar um inimigo político ou a garantir-lhes ganhos financeiros, mesmo que indevidos, em litígios sobre a herança de um parente, por exemplo. Uma das formas de Isócrates para reforçar seu èthos de afastamento dos espaços públicos, portanto, era propor discursos sobre temas importantes, relativos aos problemas das poleis e da Grécia, dizendo ele não tratar de contratos particulares (vd., por exemplo, o Panegírico 4).
} 
pública, ela determina a dedicação exclusiva de Isócrates à sabedoria e educação, ${ }^{18}$ configuradas como o verdadeiro exercício da política. Assim, a escrita afirma-se na obra do autor como um meio privilegiado de participação na vida pública, e Isócrates reclama para seus discursos um estatuto superior à fala dos oradores nos espaços públicos, pois, enquanto esses utilizam da oratória para conseguir vantagens particulares, o autor declara o fazer pensando no bem comum. ${ }^{19}$

As passagens em que Isócrates trata de sua escolha pela escrita não nos fornecem dados biográficos confiáveis, mas são na verdade parte de uma estratégia de modelação do seu próprio $\bar{e}$ thos, pela qual o autor valoriza sua atividade pedagógica e de compositor de discursos como a verdadeira prática política. Tal estratégia, com efeito, não era estranha a Isócrates, que, na Antídose, afirmara que o meio mais eficaz de persuadir a audiência era cultivar a boa reputação entre os concidadãos:

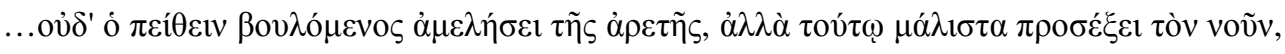

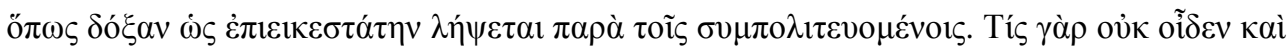

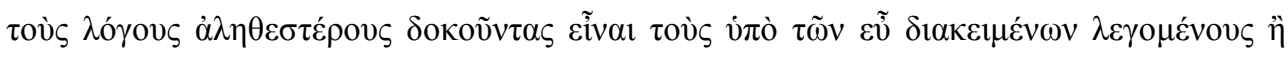

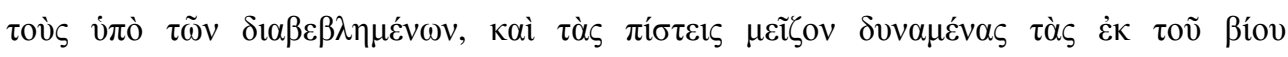

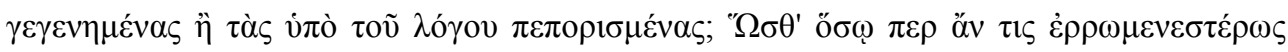

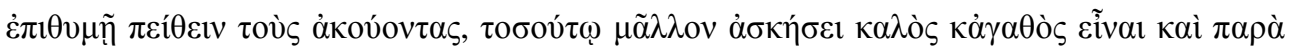

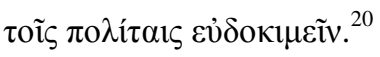

...o que deseja persuadir não descurará da virtude, mas, mais do que qualquer outra coisa, ele se atentará a ela, a fim de transmitir o máximo possível uma reputação de homem justo a seus concidadãos. Pois quem desconhece que os discursos que são reputados como mais verdadeiros são os que são falados por quem se porta bem, e não por aqueles que são difamados, e que as evidências mais convincentes advêm da vida dos que discursam e não são fornecidas pelo discurso? De forma que, quanto mais fortemente se deseje persuadir os ouvintes, tanto mais deverá se esforçar em ser bom e nobre e adquirir uma boa reputação entre os cidadãos.

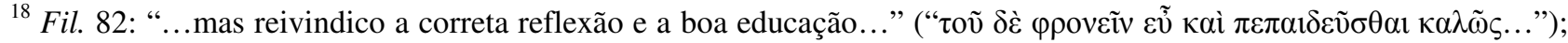
Panat. 11: “...porque não tive sucesso na vida pública, refugiei-me em filosofar, em trabalhar e em escrever minhas

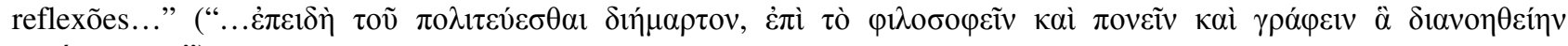

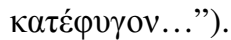

${ }^{19}$ Panat. 12: "Ora, todos sabem que muitos dos oradores ousam pronunciar-se publicamente em virtude não do que é

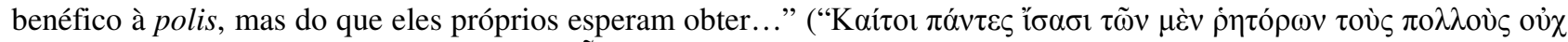

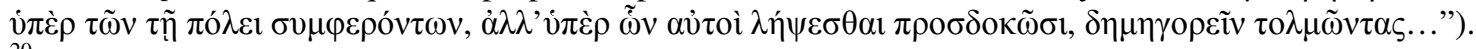

${ }^{20}$ Antíd. 277-78.
} 
A aproximação dessa passagem com a Retórica aristotélica é natural, uma vez que a obra descreve um expediente semelhante ao de Isócrates, o argumento ético. ${ }^{21}$ Tal como na Antídose, Aristóteles afirmava que, nos discursos públicos, o meio mais eficiente de se convencer a audiência não eram os argumentos relativos às questões em discussão, uma vez que a retórica trata do que é contingente e que, portanto, sobre aquilo que não se é possível chegar a uma certeza indubitável. ${ }^{22}$ Dessa forma, por não terem completa segurança das propostas que lhes eram feitas, não raro os ouvintes aprovavam aquelas que eram pronunciadas pelos homens que mais lhe parecessem confiáveis.

Mas, se as duas exposições guardavam semelhanças entre si, é preciso notar, contudo, que Aristóteles e Isócrates divergiam em um ponto central, pois o primeiro prescrevia que a opinião favorável da audiência deveria resultar tão somente da exposição do caráter do orador em seu discurso. ${ }^{23} \mathrm{Na}$ Antídose, por outro lado, afirmava-se que a boa reputação entre os concidadãos advinha, sobretudo, de suas condutas e da vida pregressa daquele que falava. A boa reputação, porém, ao menos no caso do próprio Isócrates, também era moldada por seus discursos, e as constantes referências que o autor fazia a seu afastamento dos espaços públicos visavam à construção de uma imagem de cidadão exemplar entre seus concidadãos.

Considerando o procedimento de Isócrates e quais as implicações da escolha pelo autor desse meio como forma de intervir na política de seu tempo, pois, podemos agora prosseguir na análise da datação proposta pelos estudiosos para o Panegírico. Como dissemos acima, alguns comentadores se apressaram em estabelecer a data inferida a partir do parágrafo 126 como o momento em que o discurso teria sido divulgado ao público. Mas, ainda que tivéssemos alguma evidência a suportar tal hipótese, é menos importante determinar o momento preciso em que o discurso apareceu pela

\footnotetext{
${ }^{21}$ Ret. 1356 a $4-13$.

${ }^{22}$ Ret. 1356a6-8: "Confiamos mais facilmente e mais rápido nas pessoas honestas, em todos os assuntos em geral, e quando não se é possível ter um conhecimento preciso, mas há espaço para a dúvida, essa confiança é completa.” (“тoĩ

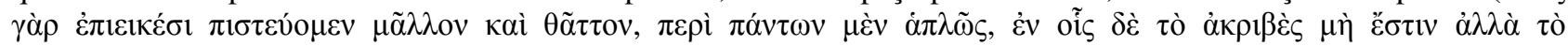
$\grave{\alpha} \mu \varphi 1 \delta o \xi \varepsilon \tilde{\imath} v, \kappa \alpha i ̀ ~ \pi \alpha v \tau \varepsilon \lambda \tilde{\omega} \zeta . ")$.

${ }^{23}$ Ret. 1356a8-10: "É necessário que isso [a persuasão pelo ēthos] aconteça por meio do discurso, e não por causa da

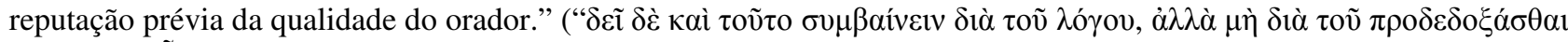

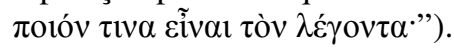


primeira vez, se considerarmos o modo de difusão, na antiguidade, dos textos escritos. Nada impediria, por exemplo, que o Panegírico sofresse alterações mesmo depois de publicado ou que, antes de sua divulgação para um público maior, versões prévias do texto fossem apresentadas aos alunos da escola de Isócrates, e, a partir dos comentários então feitos, o autor corrigisse o texto do discurso. Ao menos esse procedimento deveria fazer parte dos métodos de ensino utilizados por Isócrates, ${ }^{24}$ já que, em duas ocasiões, ${ }^{25}$ ele diz ter submetido aos alunos obras suas, as quais só publicou após deixar-lhes claro o valor desses escritos.

A composição, assim, poderia coligir passagens compostas em diferentes períodos, o que alguns comentadores afirmam ter acontecido com o Panegírico, como modo de resolver uma inconsistência na data aparentemente indicada pelo discurso: ${ }^{26}$ o parágrafo 141 refere-se a Evágoras correntemente resistindo aos avanços do rei persa, em 380 a.C., portanto, segundo a datação acima; isso contrasta, porém, com o testemunho de Diodoro da Sicília, que afirma ter o rei cipriota sucumbido em 385 a.C., ${ }^{27}$ alguns anos antes da suposta redação do discurso. É verdade que Diodoro nem sempre era cuidadoso ao reproduzir os dados encontrados nessas fontes primárias, tendo sido apontados pelos estudiosos da história grega diversos erros em sua narrativa; dessa forma, alguns comentadores consideraram que a divergência das datas do Panegírico com aquela apontada por Diodoro resultava de uma confusão desse último, que adiantara a queda do tirano em alguns anos, quando, na verdade, ela teria acontecido após 380 a.C. ${ }^{28}$

\footnotetext{
${ }^{24}$ Esse uso corresponde à tarefa que Isócrates atribui ao professor no Contra os Sofistas de "fornecer em si mesmo tamanho exemplo, de modo que os assim formados e capazes de imitar parecerão falar de maneira mais elegante e

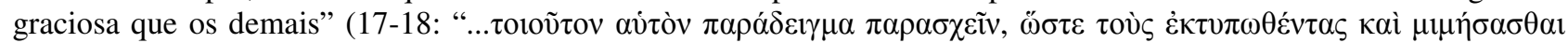

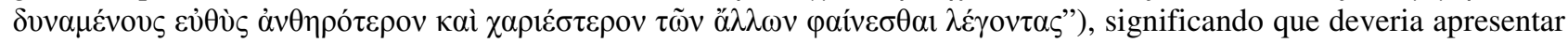
seus próprios discursos para que os alunos imitassem e, a partir deles, produzissem suas próprias composições.

${ }^{25}$ Panat. 200-65; Fil. 22-23. Nas duas passagens, o autor aparece lendo os respectivos discursos aos discípulos, que apresentavam seus elogios ou suas objeções aos textos, em discussões que precediam a divulgação dos textos ao público fora do círculo pessoal do autor.

${ }^{26}$ Não é o caso, porém, de se falar de duas "edições" diferentes, uma de 385-84 e outra de 380 a.C., como faz Engel (De Tempore quo divulgatus sit Panegyricus, Gymn. Programma, n. 4, 1861, apud Mathieu: 1956, vol II, p. 5; Blass: 1874, vol. II, p. 230), pois pequenas alterações poderiam ser feitas ao longo dos anos, sem que elas implicassem em versões definitivas para a publicação, como o conceito moderno de edição dá a entender.

${ }^{27}$ Bibliot. XV, 8 .

${ }^{28}$ Hipótese referida por Blass (1874, vol. II, p. 230).
} 
Essas observações a respeito da datação do Panegírico, porém, somente tem sentido se se admitir que Isócrates partilhava do mesmo rigor cronológico que seus comentadores modernos e que ele estivesse interessado em nos fornecer um retrato preciso dos eventos concomitantes à composição do discurso. Não seria, porém, mais coerente com os objetivos do autor uma maior liberdade na apropriação dos eventos históricos, relatando-os da forma que melhor se adequassem aos argumentos de seu discurso? O próprio uso da escrita, de fato, parece corroborar tal juízo, pois, não estando restrito à audiência encontrada em algum evento público, um texto escrito seria acessível a muitos leitores em épocas diferentes, para os quais pouco importava uma eventual imprecisão no ordenamento cronológico dos fatos relatados, mas a consistência de seu uso dentro das propostas defendidas por Isócrates. Dessa forma, para um grego que lesse o discurso, pouco importava se Evágoras tivesse resistido além do período de sua publicação ou tivesse sucumbido antes, uma vez que seu reino estivesse sobre o domínio persa. Ainda assim, porém, o episódio forneceria um exemplo de resistência ao rei Artaxerxes, contra o qual Isócrates dirigia seu discurso, e dessa forma contribuía para os objetivos desejados pelo autor com sua composição.

Esse caso torna mais clara a maneira como Isócrates tratava os eventos históricos, adquirindo uma função exemplar, na qual os feitos pregressos tornavam-se modelos para os que liam o discurso. O uso exemplar dos fatos do passado, de fato, não era um expediente exclusivo de Isócrates, sendo encontrado em autores contemporâneos. De forma que podemos atribuir uma importância menor à data do parágrafo 126 do discurso, sendo ela não uma indicação precisa de determinado período, mas apenas consequência do relato de eventos que, por acaso, são cronologicamente próximos.

O Menéxeno, de Platão, é prova disso. A obra consistia quase que integralmente em um discurso recitado pelo usual protagonista platônico, Sócrates, e contém um flagrante anacronismo: a menção à Paz de Antalcidas, acordada em 387 a.C., ${ }^{29}$ por Sócrates em seu discurso (245 d-e),

\footnotetext{
${ }^{29}$ Sobre a Paz de Antalcidas, vd. abaixo p. 27-29.
} 
entrava em conflito com a morte dessa figura histórica em 400 ou 399 a.C. O Menéxeno, nesse aspecto, de forma alguma representa uma exceção na obra do filósofo, uma vez que Platão não era muito rigoroso com a ordenação cronológica dos eventos por ele referidos, sendo encontrados numerosos os anacronismos em seus diálogos. ${ }^{30}$ Sendo assim, não surpreende outro notável anacronismo encontrado nesse discurso: a referência a Aspásia, de cuja autoria seriam as orações fúnebres pronunciadas por Péricles ${ }^{31}$ e que Sócrates afirma ter-lhe ensinado, na véspera do encontro com Menéxeno (236b), o discurso que ele pronunciaria. Embora não disponhamos de nenhuma evidência quanto a sua morte, é razoável pensar que ela não sobrevivesse até 387 a.C., data a partir da qual o Menéxeno deve ter sido composto, uma vez que ela deveria ter cerca de trinta anos em 429 a.C., quando morreu Péricles.

Dessa forma, a impossibilidade de circunscrever o Menéxeno a um momento preciso no tempo é apenas o corolário de uma série de omissões e liberdades no relato histórico recitado por Sócrates: quando ele trata da expedição ao Egito (241e), por exemplo, não menciona seu desfecho desastroso, já que os atenienses terminam como prisioneiros do persa Megabizo; ${ }^{32}$ tampouco no episódio histórico conhecido como "Guerra de Arquidamo" (431-421 a.C.: 242c), quando se ignoram as insurreições nas poleis da Trácia e da Calcídia, e a tomada de Anfípolis pelo comandante espartano Brasidas.

\footnotetext{
${ }^{30}$ Para citar apenas um exemplo, o Fedro apresenta uma situação difícil de ser conciliada com um momento histórico preciso: entre 415 e 403 a.C., o personagem que dá nome ao diálogo estava no exílio, por conta de sua participação na destruição das estátuas de Hermes. O diálogo, portanto, deveria ter ocorrido entre 403 e 399 a.C., data mais tardia para a morte de Sócrates; tal hipótese é descartada, contudo, porque há indicações no texto que fazem referência a Sófocles e Eurípides como ainda vivos (268c), e ambos os tragediógrafos morreram antes do retorno de Fedro, em 406 a.C. Tampouco seria possível situar sua conversa com Sócrates em um momento anterior a 415 a.C., pois Lísias, o qual Fedro diz, no início do diálogo, ter acabado de ouvir discursar, chegara a Atenas de sua Sicíla natal somente em 412 a.C. Como nota Nehamas, em sua introdução ao diálogo: "In fact, there doesn't seem to have been a time when this meeting between Phaedrus and Socrates could have occurred." (Nehamas; Woodruff: 1995, p. xiii).

${ }^{31}$ Qualquer que fosse a influência de Aspásia sobre Péricles, deve-se notar que, ao menos na posteridade, os gregos acreditavam ter Péricles atacado Samos, em 440 a.C., apenas para agradar sua concubina, como relata Plutarco na Vida de Péricles (24-25). É mesmo possível que o Menéxeno tenha contribuído para o surgimento desse rumor, ao caracterizar como servil a relação de Péricles para com Aspásia. Nesse caso, pode-se atestar o sucesso do diálogo em levantar a suspeita contra o político ateniense, uma figura histórica que não contava com a simpatia de Platão e que já havia sido alvo de ataques em outros diálogos, como no Górgias, em que é identificado com o tipo de homem público que o antagonista Cálicles deseja se tornar (515c-16d).

${ }^{32}$ Tuc. Hist. I, 109-10.
} 
A inconsistência cronológica do relato platônico, porém, não devia ser relevante para os leitores. De fato, pronunciar seu discurso fúnebre, Sócrates se apropria dos fatos históricos, mas os apresenta de uma maneira favorável a seu objetivo, que é o de louvar Atenas. Nesse quadro, os eventos adquirem significado justamente por serem tópicos dos quais se poderia extrair um elogio da polis.

A partir dessa análise, podemos concluir que os fatos do passado assumiam a função de paradeigmata nos discursos de Isócrates; resta-nos questionar qual era o significado desses exemplos, e como se dá esse uso no Panegírico. Quanto ao significado dos paradeigmata na obra de Isócrates, um exame do restante da obra do autor nos ajuda a melhor compreender essa questão. No Contra os Sofistas, com efeito, o autor inclui, entre as tarefas do professor, "fornecer em si mesmo tamanho exemplo, de modo que os assim formados e capazes de imitar parecerão falar de maneira mais elegante e graciosa que os demais". ${ }^{33}$ Como referimos anteriormente em nota, ${ }^{34}$ essa prescrição de Isócrates poderia ser estendida à prática do autor em sua escola, na qual seus discursos provavelmente eram usados como modelos para os alunos.

Embora a passagem em questão discuta o aprendizado da oratória, não se pode limitar o caráter exemplar que Isócrates imprimia a sua obra meramente à composição de discursos, pois tal interpretação iria contra justamente o que diz o Contra os Sofistas: no parágrafo 12, com efeito, o autor critica o esquematismo de alguns de seus rivais, que "não se dão conta de que trazem, como paradigma de assuntos criativos, uma arte rígida". ${ }^{35}$ A palavra "arte" (technē) aí encontrada não se referia apenas à disciplina característica desses professores, mas também englobava um de seus instrumentos de ensino, as technai. ${ }^{36-37}$ Embora também tivessem em comum a função de servir aos

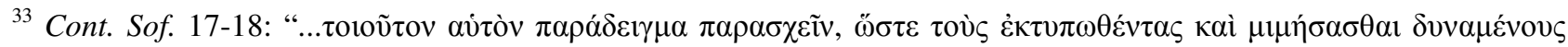

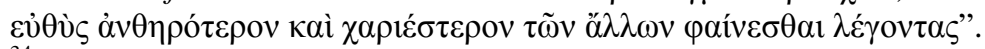

${ }^{34} \mathrm{vd}$. acima nota 24 deste capítulo, p. 15.

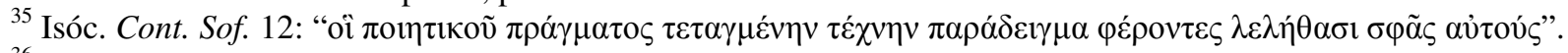

${ }^{36}$ Seguimos aqui a tese de Thomas Cole (1991, p. 71-94). Defende o estudioso que as technai eram discursos modelares servindo ao aprendizado da oratória, tendo a forma de um discurso fictício apresentado a um tribunal ou em uma assembleia, mas consistindo em sua maior parte nos argumentos aptos ser utilizados em tais ocasiões. O fundamento para essa posição encontra-se nas Refutações Sofísticas (183b35-184b8), de Aristóteles, em que o filósofo descreve o ensino retórico de seu tempo consistindo basicamente na imitação de modelos fornecidos pelos professores: "davam
} 
estudantes como modelo na composição de seus próprios discursos, as technai se distinguiam dos textos isocráticos pela sua rigidez (tetagmenē): os exemplares supérstites do que hoje supomos serem technai eram discursos fictícios de pequena extensão, consistindo quase que apenas em argumentos a defender determinada posição e, devido a sua simplicidade, esses discursos podiam ser facilmente utilizados por um estudante ou um leigo, que, quando lhes fosse necessário discursar em uma ocasião pública, adaptariam os argumentos lá encontrados. ${ }^{38}$ Ainda que úteis no aprendizado da composição de discursos, esses textos não eram comparáveis à educação (paideia) oferecida por Isócrates, e desconsiderava, por exemplo, a adequação (prepon) dos argumentos à situação em que seriam empregados. ${ }^{39}$

No Contra os Sofistas, ademais, Isócrates censurava os tipos de ensino concorrentes por sua negligência em relação às obrigações éticas do professor. $\mathrm{O}$ autor, é verdade, negava ser capaz de tornar seus alunos mais justos, se esses não possuíssem uma natureza adequada a isso; essas afirmações, porém, tinham, em primeiro lugar, a função de refutar as críticas geralmente endereçadas aos professores de oratória, a saber, que seu ensino corrompia os estudantes e os tornava maus cidadãos. Assim, logo adiante no Contra os Sofistas, Isócrates também diz que seus

[aos alunos] discursos - uns consistindo de perguntas e respostas; outros, retóricos - para memorizarem...” (“ $\lambda$ ó $\gamma o v \varsigma$

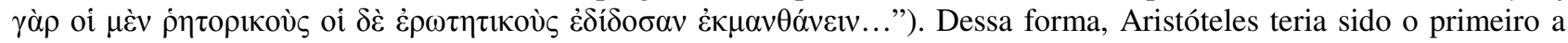
tratar da retórica de uma perspectiva técnica, escrevendo um tratado, isto é, uma obra em que a disciplina era exposta segundo categorias abstratas.

Uma passagem do Fedro, porém, parece contrariar o testemunho das Refutações Sofísticas: Sócrates, em 266d-268a, procede a uma pequena história da retórica. Nesse inventário, as inovações de cada um dos expoentes da disciplina são arroladas segundo categorias abstratas, indicando talvez que os primeiros professores de oratória não se utilizavam exclusivamente da imitação de discursos, mas possuíam algum tipo de teoria a respeito do que ensinavam.

A natureza das technai, portanto, ainda é uma questão polêmica entre os estudiosos. Sem qualquer pretensão de resolver definitivamente a querela, gostaríamos de observar que as duas teses sobre as technai não são mutuamente exclusivas, sendo possível que, nos séculos V e IV a.C., tanto os discursos modelares quanto os tratados sobre oratória fossem igualmente denominados technai. Mas, no caso dos discursos, ao menos, contamos com textos que podemos classificar como technai - as Tetralogias, de Antifonte; enquanto, no caso dos tratados, não se dispõe de exemplo seguro desse gênero de escritos antes de Aristóteles (a data da Retórica a Alexandre permanece desconhecida). Por esse motivo, é conveniente adotarmos neste trabalho o entendimento de Cole, uma vez que a descrição de tais escritos pelo estudioso corresponde ao que Isócrates diz a seu respeito no Contra os Sofistas.

${ }^{37}$ No parágrafo 19 do mesmo Contra os Sofistas, o autor faz referência aberta às technai, ao mencionar "os que

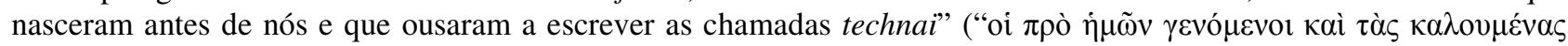

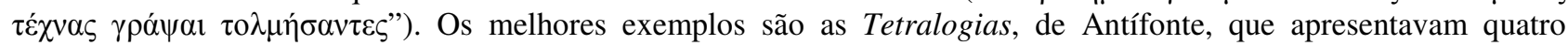
discursos sobre uma mesma questão judicial, sendo dois da defesa, os dois restantes da acusação.

${ }^{38}$ Cole: 1991, p. 71-94. Para maiores detalhes sobre as technai, vd. p. 54 et seq. deste estudo.

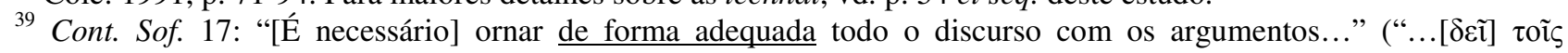

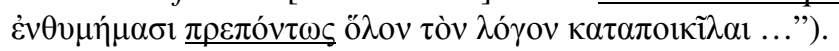


alunos adquirem, mais rápido que a eloquência (rhētoreia), a justiça, explicitando as preocupações que o autor tinha em mostrar que formava bons cidadãos. ${ }^{40} \mathrm{~A}$ formação ética e política dos alunos, portanto, era uma das tarefas do educador, e seus discursos, também utilizados na educação dos jovens, deveriam fornecer exemplos adequados da conduta como cidadão. Dessa forma, torna-se claro que, quando Isócrates prescreve que o orador deve fazer de si mesmo um exemplo para seus alunos, essa afirmação não está tão somente limitada à composição de discursos, mas abrange a conduta que seus alunos devem apresentar.

Discursos como o Para Nícocles e o Nícocles, por exemplo, prestavam-se a fornecer exemplos para seus leitores, o primeiro direcionando a boa conduta dos governantes, o outro, a dos súditos. Do mesmo modo, poderíamos pensar que o Panegírico como um paradeigma endereçado aos homens que governam a Grécia. Nos parágrafos 170-72, com efeito, Isócrates censura os homens que detêm o poder nas poleis, por se ocuparem de questões de pouca importância, negligenciando os verdadeiros problemas da Grécia, isto é, o autor critica os líderes gregos de guerrearem entre si, quando deveriam se unir para derrotar os persas. A passagem oferece a Isócrates nova oportunidade para se usar do topos de seu afastamento da política ativa, pois, face à insensatez dos governantes, diz o autor, ele é obrigado a abandonar sua vida tranquila para indicarlhes a correta resolução dos problemas da Grécia. Para os nossos objetivos, porém, o importante dessa passagem é a delimitação que ela faz do público que Isócrates desejava atingir com seu discurso.

Por óbvio, tal indicação não implica que o discurso estivesse restrito aos governantes da Grécia e que o autor o tivesse composto pensando exclusivamente nesses homens, assim como o Filipe, embora se referisse de modo explícito ao monarca macedônio, certamente não estava

\footnotetext{
${ }^{40}$ Cont. Sof. 21: "Ora, os que desejam obedecer as prescrições dessa filosofia serão auxiliados de modo muito mais

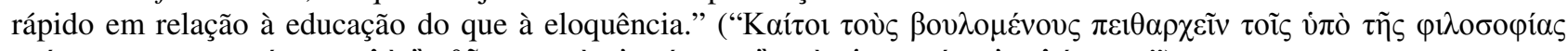

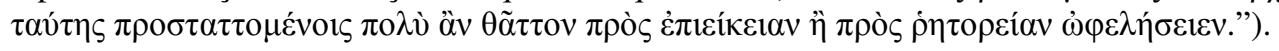


limitado a ele, sendo lido pelo usual público de Isócrates. ${ }^{41}$ Podemos pensar que essa menção ao público feita por Isócrates, pois, era também uma estratégia do autor, no caso, para reforçar a inserção política do discurso, um exemplo aos governantes da Grécia. Mas o paradeigma do Panegírico não estava restrito a eles, uma vez que, um pouco adiante, o autor novamente refere-se ao público do discurso, dessa vez dividido entre "aqueles capazes de agir" e "aqueles que discutem discursos". 42

Essa nova divisão do público do Panegírico coloca em evidência outro tipo de leitor, um que, como Isócrates, embora não seja capaz ele mesmo de agir (não tendo o poder político para formar a coalizão entre os gregos), pode, por meio de seus discursos, induzir os homens que governam a Grécia a decidir corretamente. Como condição, Isócrates afirma que esses homens devem parar de "escrever a respeito da fiança e acerca das outras futilidades de que agora se ocupam, e tentar competir com este discurso e investigar como falarão melhor do que eu a respeito dos mesmos assuntos." A referência aos discursos aos quais esses homens se dedicam pode ser aproximada das technai, em razão de seu conteúdo judicial, uma vez que Aristóteles, no início da Retórica, afirma que os compositores desse tipo de escrito haviam se dedicado sobretudo ao gênero judiciário, ignorando completamente o gênero deliberativo, embora esse último fosse mais útil (1354b22-29). ${ }^{43}$

No Panegírico, mais de uma vez Isócrates contrapõe de forma crítica seu discurso aos textos de caráter judicial usualmente utilizados no ensino da oratória. No proêmio do discurso (11), ponto de comparação é a elocução, o autor censurando a elocução demasiado simples dos textos judiciais,

\footnotetext{
${ }^{41}$ Quanto ao Filipe, é duvidoso mesmo que o discurso tenha sido lido por essa figura histórica, uma indagação que pode ser estendida às epístolas atribuídas a Isócrates (a autenticidade desses textos ainda é assunto de debates entre os estudiosos), todas elas individualmente endereçadas a tiranos ou a seus filhos.

${ }^{42}$ Paneg. 188: "E vós não deveis ir embora como se fossem simples ouvintes, mas aqueles capazes de agir devem mutuamente exortar-se a tentar reconciliar a nossa cidade e a dos lacedemônios, e os que discutem os discursos devem parar de escrever a respeito da fiança e acerca das outras futilidades de que agora se ocupam, e tentar competir com este

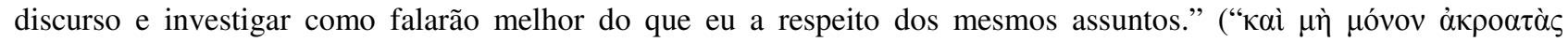

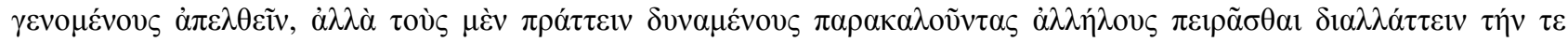

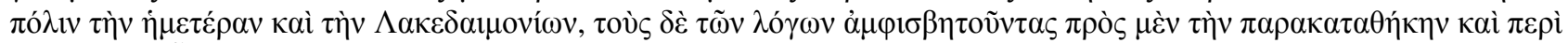

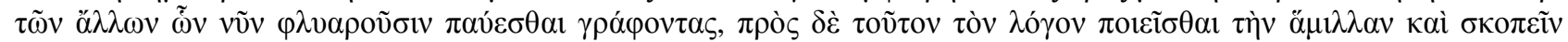

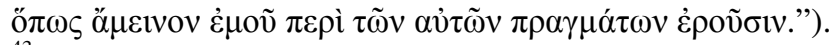

${ }^{43} \mathrm{Se}$, como Thomas Cole afirma, as technai eram discursos servindo de modelos para os alunos, poderíamos classificar os discursos de Lísias, servindo também eles para o aprendizado da composição de discursos, de technai?
} 
ao mesmo tempo em que diz que seus discursos são “extremamente elaborados”. Certamente o esquematismo e aridez característicos das technai eram resultado de seu uso por leitores não especializados como fonte de argumentos para o uso em tribunal ou em outra instância pública, uma vez que tanto a urgência da situação quanto o público essencialmente leigo não permitiam uma leitura mais cuidadosa, exigindo uma escrita que pudesse ser rapidamente entendida e adaptada para uma variedade de casos diferentes. A elocução muito particular que Isócrates procura desenvolver no Panegírico, por outro lado, pode ser entendida como uma forma de selecionar uma audiência específica (como a dos alunos que frequentavam sua escola), a qual disporia de ócio para examinar com vagar e discutir as propostas feitas pelo autor no discurso. ${ }^{44}$

No final do discurso (188), Isócrates volta a fazer referência aos textos judiciais, mas, dessa vez, o critério pelo qual o autor os julga é sua utilidade como instrumentos políticos. O autor inicia a passagem com o autor declarando que não conseguiu atingir o objetivo prometido no início do discurso. ${ }^{45}$ Não se deve, porém, atribuir a tais afirmações um valor confessional, como se Isócrates realmente, ao chegar ao final do Panegírico, percebendo que o discurso não seria o suficiente para convencer seus contemporâneos a se unirem em uma campanha contra a Pérsia, exortasse seus leitores a fazê-lo. Pelo contrário, trata-se de uma estratégia discursiva muito sutil, pela qual o autor deixa entrever a função modelar que ele queria imprimir em seus discursos. Um dado importante dessa passagem é a referência que se faz ao público leitor do discurso, dividido em duas classes diferentes segundo sua participação na vida pública: aqueles que levam uma vida pública ativa, participando das assembleias e demais instâncias públicas; e aqueles, que, a exemplo do próprio

\footnotetext{
${ }^{44}$ A leitura de textos isocráticos pelos alunos de sua escola é encenada em dois textos do autor. No Filipe, Isócrates descreve o processo pelo qual teria passado o discurso antes de ser mostrado ao público (17-23), o autor lendo-o um esboço prévio a seus alunos, que faziam críticas e sugeriam ao professor se ele deveria publicá-lo ou não. De forma mais demorada, a última seção do Panatenaico exibe o mesmo procedimento, dessa vez apresentando a discussão do autor com um de seus alunos (199-265).

${ }^{45}$ Paneg. 14: "Quanto a mim, porém, se minha fala não estiver à altura do assunto, da minha própria reputação e do tempo - não só o que gastei com o discurso, mas também de todo o tempo de minha vida -, recomendarei que não haja nenhuma desculpa, mas, ao contrário, o riso e o desdém, pois não há nenhuma de tais coisas que eu não mereça sofrer,

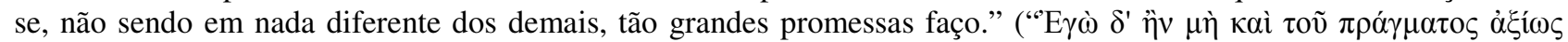

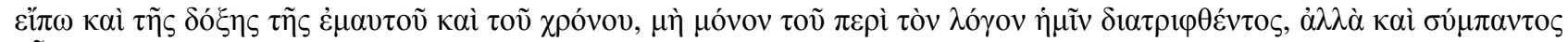

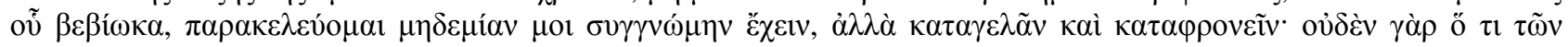

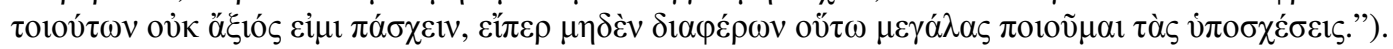


Isócrates, não tomam parte de forma direta na política, mas, escrevendo discurso e educando os demais cidadãos, influenciam no governo das poleis. Aos últimos, o autor insta a desistir de tratar da fiança, um dos tópicos característicos dos discursos judiciais.

Assim, ao abordar um problema de importância para toda a Grécia, Isócrates tratava uma questão que possivelmente teria um interesse geral para todos os gregos, "a qual, se corretamente resolvida", diz o autor, "nos livrará das guerras mútuas, da presente desordem e dos maiores males"; ${ }^{46}$ as technai, em comparação, eram em geral vistas como tendo um alcance bem mais restrito, pois dedicadas a litígios sobre a vida privada de particulares, aparentemente sem qualquer impacto para o resto da população. ${ }^{47}$ Os tribunais, de fato, não somente se prestavam à obtenção vantagens pessoais, mas também permitiam que se perseguissem inimigos políticos, ${ }^{48}$ não sendo de todo injustificada a má fama que os atenienses atribuíam aos frequentadores habituais desses espaços.

Mas os últimos parágrafos do Panegírico, além de revelarem a atitude de Isócrates para com os discursos que ele considera opostos aos seus, permitem-nos vislumbrar como o autor concebia sua própria produção escrita, e mesmo qual o impacto que ela poderia ter na política contemporânea. O autor decide terminar o discurso de forma um tanto surpreendente: após as declarações no início do Panegírico de que o discurso superaria todos os demais compostos sobre o

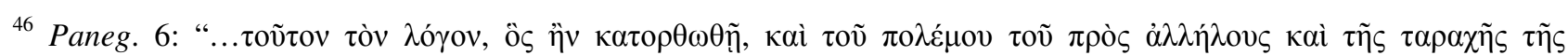

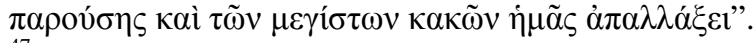

${ }^{47}$ Pelo menos esse é o entendimento de Aristóteles, que, em um trecho da Retórica referido acima (p. 22), estabelece com base na utilidade para a polis a superioridade dos discursos deliberativos sobre os judiciários: "...é o mesmo o método da oratória pública e o da judicial, e mais belo e mais digno de um cidadão se ocupar dos discursos de

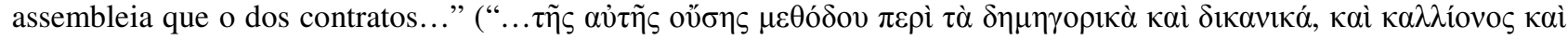

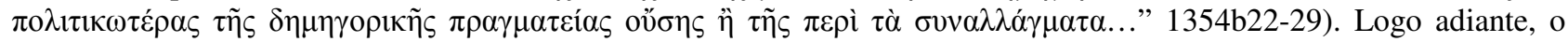
filósofo explica seu desapreço pela oratória judiciária pelo fato de ela estar sujeita aos subterfúgios e truques, uma vez que os juízes nos tribunais decidem sobre eventos que lhes são alheias e permitem que os oradores falem sobre questões alheias ao caso; nas assembleias, por outro lado, os cidadãos deliberam sobre questões que são de seu próprio interesse, havendo pouco espaço para que o orador saia fora do tema.

${ }^{48}$ No Contra Timarco, por exemplo, Ésquines processa o político ateniense Timarco de prostituição masculina, mas é provável que tal acusação fosse apenas um pretexto para cassar os direitos de um dos maiores opositores da política prómacedônica. Timarco, com efeito, já havia levado ao tribunal o orador, em um julgamento que quase lhe custou a vida, por sua participação no acordo de paz com Filipe da Macedônia em 346, considerado como prejudicial a Atenas.
} 
mesmo tema e a exortação para que, se não cumprisse o que fora prometido. ${ }^{49}$ Não se deve, por óbvio, atribuir a tais afirmações um valor confessional, como se Isócrates realmente, ao chegar ao final do Panegírico, percebesse que o discurso não seria o suficiente para convencer seus contemporâneos a se unirem em uma campanha contra a Pérsia e então exortasse seus leitores a fazê-lo. Pelo contrário, trata-se de uma estratégia discursiva muito sutil, pela qual o autor deixa entrever a função modelar que ele queria imprimir em seus discursos.

Ao contrário, Isócrates desafiava esses homens a superar o discurso que então liam, compondo também eles sobre a união dos gregos e a guerra contra os bárbaros. Dessa forma, o autor fazia uma referência a seu próprio método de ensino, estabelecendo o Panegírico como um modelo na composição de discursos, mas um modelo que se tornava guia da conduta ética e política de seus leitores e que, em última instância, poderia resolver os problemas da Grécia.

b) erga

As liberdades que Isócrates toma quanto aos fatos históricos não se limitavam a sua ordenação cronológica, mas elas também se faziam presentes na seleção de determinados eventos para serem incluídos no discurso e no modo como esses eventos são narrados. A proposta inicial do Panegírico - "aconselhar a respeito da guerra contra os bárbaros e a concórdia entre nós mesmos [os gregos]", ${ }^{50}$ significando a organização de uma pan-helênica contra o Império persa -, é o ponto em torno do qual Isócrates articula a narrativa histórica por ele desenvolvida, moldando os fatos do passado de acordo com sua adequação a tal objetivo. Dessa forma, para argumentar quanto à necessidade de união entre os gregos e ao fim das dissensões internas na Grécia, o autor expõe os

\footnotetext{
${ }^{49}$ Paneg. 14: "Quanto a mim, porém, se minha fala não estiver à altura do assunto, da minha própria reputação e do tempo - não só o que gastei com o discurso, mas também de todo o tempo de minha vida -, recomendarei que não haja nenhuma desculpa, mas, ao contrário, o riso e o desdém, pois não há nenhuma de tais coisas que eu não mereça sofrer,

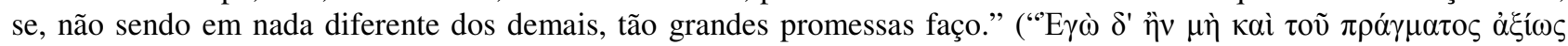

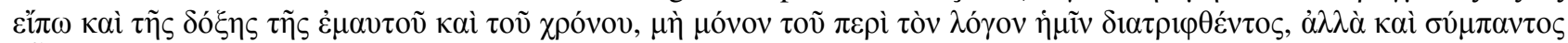

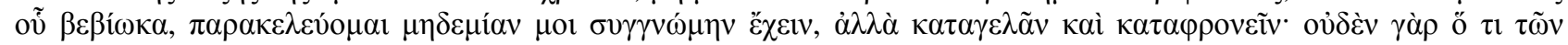

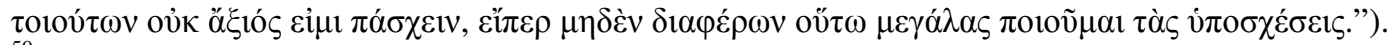

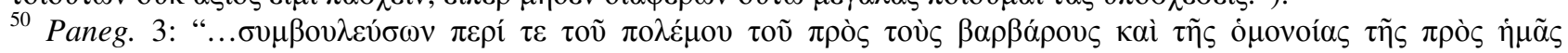
av̉ioùs...".
} 
diversos conflitos que aconteciam no período em que se insere o discurso, enquanto a incursão grega à Ásia é retratada tanto como um ataque preventivo contra os grandes inimigos dos gregos quanto como uma maneira de recuperar as poleis gregas na Jônia presentemente sob a posse do rei persa.

Embora não possamos estabelecer uma data precisa para a apresentação do discurso ao público, vimos que, ao descrever eventos supostamente simultâneos à composição do discurso, o autor ancora o relato do Panegírico em um intervalo temporal mais ou menos determinado, as primeiras décadas após a Guerra do Peloponeso. Vai-se permitir aqui tratar dos erga, ou seja, das questões históricas que Isócrates aborda em seus argumentos, a partir de outros relatos contemporâneos a ele ou de historiadores modernos, de forma que, com a contraposição do relato do autor a outras fontes, possamos aclarar as especificidades da exposição dos eventos do passado no Panegírico.

Ao proceder a nosso inventário dos fatos relatados pelo Panegírico, convém estabelecer uma fonte histórica com a qual possamos comparar a narrativa que Isócrates faz em seu discurso, e a escolha natural para essa posição é a obra de Xenofonte As Helênicas, o único tratado historiográfico contemporâneo que cobre o período do texto isocrático e que também chegou até nós em sua integralidade. Nossa decisão de limitar o relato desta seção a basicamente apenas esta obra deveu-se não tanto a autoridade de Xenofonte como fonte histórica, mas sobretudo ao fato de que as Helênicas abrangem o mesmo período tratado no Panegírico, ${ }^{51}$ fornecendo-nos um retrato que, embora se possa questionar sua fidelidade, é ao menos largo o bastante para que possamos colher informações a respeito de eventos referidos no discurso de Isócrates. ${ }^{52}$ Nossa exposição, ademais, estará restrita aos eventos próximos ou concomitantes ao período em que o discurso se

\footnotetext{
${ }^{51}$ A obra de Xenofonte se inicia exatamente no mesmo momento em que termina a de Tucídides, em 411 a.C., e chega até 362 a.C., na batalha de Mantineia. Fragmentos existem de outras obras a cobrir o mesmo período, a doxografia conservada de Teopompo e uma obra anônima, encontrada em um papiro na cidade egípcia de Oxirrinco, geralmente referida como Helênica de Oxirrinco, esta última sendo geralmente considerada fonte para Diodoro da Sić́lia nos anos posteriores a 386 a.C.

${ }_{52}$ A respeito de um episódio específico narrado no discurso - "a marcha dos dez mil" -, utilizaremo-nos também de Xenofonte, mas de outra de suas obras, a Anábase (vd. p. 29-30 deste trabalho).
} 
situa, pois eles oferecem casos em que podemos comparar com a exposição de autores contemporâneos à de Isócrates, e daí depreender o modo como o autor modela sua história. ${ }^{53}$

Comecemos, pois, a tratar um dos temas inicialmente propostos por Isócrates em seu discurso, a concórdia helênica. Para reforçar a necessidade de união entre os gregos, o autor então retoma os recentes conflitos entre na Grécia, enfatizando os problemas que resultaram dessa inimizade. No centro desses conflitos estavam Atenas e Esparta, as maiores potências militares helênicas, as quais anteriormente disputavam o domínio da Grécia. Naquele momento, Esparta, como consequência da vitória na Guerra do Peloponeso, possuía um maior poder militar, mas a primazia espartana não trouxe paz à Grécia, pois as principais poleis viam com desconfiança sua política expansionista, ${ }^{54} \mathrm{o}$ que mais tarde tornar-se-ia motivo para a eclosão de novos conflitos: em 395 a.C., ou seja, nem dez anos após a vitória definitiva sobre os atenienses, as outrora aliadas dos espartanos Corinto e Tebas juntaram-se às suas antigas inimigas Atenas e Argos para combater Esparta, em um evento que a historiografia denominou "Guerra de Corinto". 55

A guerra durou oito anos, e não se pode dizer que seu desfecho tenha sido vantajoso para nenhuma das principais antagonistas: Atenas não conseguiu recuperar sua antiga posição de controle sobre a maior parte da Grécia; Esparta, por outro lado, embora viesse a manter a

\footnotetext{
${ }^{53}$ Quanto aos eventos mais longíquos no passado, como as súplicas dos heraclidas ou de Adrasto, que não serão tratados nesta seção, deve-se apenas destacar que, longe da rubrica de mitologia, ele são apresentados como eventos históricos que propiciam paradeigmata para a atuação contemporânea a Isócrates.

${ }^{54}$ Após a vitória na Guerra do Peloponeso, Esparta tentou expandir sua influência política para todas as partes do Mediterrâneo, fixando em regiões de interesse governos que lhe fossem favoráveis. Assim, além de mover-se ao leste, estabelecendo uma oligarquia em Samos, foi de grande importância para a política espartana o avanço para o norte, com a ocupação da ilha de Tasos e da Tessália pelo estratego Lisandro. Tal presença espartana certamente provocou descontentamento entre os tebanos, que habitavam ao sul dessa região. A oeste, na Sicília, depois de repelir a expedição ateniense, Esparta assegurara sua posição com o auxílio dado ao tirano Dionísio, indo contra os interesses dos coríntios, que haviam fundado Siracusa e que se opunham à tirania que lá fora instalada. Ademais, há indícios de que Esparta travara contato com os egípcios, procurando estabelecer também uma aliança ao sul. Para maiores detalhes, vd. Hornblower: 2011, p. 219-25.

${ }^{55}$ Xenofonte (Hel. III, 5, 3) e o historiador de Oxirrinco (McKechnie; Kern: 1988, p. 88-95) atribuem a causa imediata da Guerra de Corinto à disputa entre duas regiões da Grécia central, a Fócida e a Lócrida. Esse conflito local, porém, sem grande importância para a política grega como um todo, foi apenas um pretexto para que as ex-aliadas aceitassem romper pacto de paz que haviam feito entre si. Deu-se que a faç̧ão antiespartana em Tebas, desejosa da guerra, convenceu os fócios a invadir a Lócrida, tradicional aliada dos tebanos, pois isso os forçaria a intervir na guerra; os espartanos, por outro lado, viram no apelo subsequente que os fócios lhes fizeram a oportunidade entrar em guerra com Tebas e assim puni-la por não ter apoiado Esparta no final da Guerra do Peloponeso, quando essa desejava a destruição de Atenas.
} 
preeminência entre os gregos mesmo depois da guerra, teve comprometida sua ambição de expandir seu domínio para além do Peloponeso.

O tratado firmado em 387 a.C. entre os persas e os espartanos, conhecido como "Paz do Rei" ou "Paz de Antalcidas" (nome do estratego lacedemônio responsável pelas negociações), marcou o fim da Guerra de Corinto. ${ }^{56}$ A guerra, com efeito, ocasionara o acirramento dos conflitos entre as principais poleis gregas; para solucionar esse problema, os espartanos asseguravam, por meio do tratado, a autonomia das poleis na Europa, alegando que assim a Grécia estaria livre das dissensões internas.

A autonomia inscrita na letra do tratado, porém, não garantira a efetiva paz entre as poleis gregas. De fato, as lutas internas entre os gregos não cessaram com o aparecimento da Paz de Antalcidas, e foram os espartanos, desejosos por punir as poleis aliadas que não lhes ofereceram apoio durante os tempos de guerra, os primeiros a violar os termos da paz que eles próprios haviam estabelecido. ${ }^{57}$ A represália de Esparta iniciou-se logo após firmado o acordo, em 385 a.C., e teve como vítima inicial Mantineia, porque, durante a Guerra de Corinto, seus habitantes forneceram suprimentos a Argos, contra a qual, porém, guerreavam ao lado de Esparta. Como garantia de que não seriam outra vez traídos, os espartanos então exigiram de seus relutantes aliados a derrubada das muralhas que protegiam Mantineia, e os mantineus, tendo se recusado a cumprir tal ordem, deram, pois, motivo para os espartanos atacá-los. ${ }^{58}$ Algum tempo após a investida contra Mantineia, seguiram-se os cercos a Olinto e Flionta, iniciados em 382 e 381 a.C. respectivamente, outra vez reafirmando a inutilidade do tratado no que se refere à promoção da paz entre os gregos.

\footnotetext{
${ }^{56}$ O texto da Paz de Antalcidas é reproduzido por Xenofonte nas Helênicas: "O rei Artaxerxes considera justo que as poleis da Ásia pertençam a ele e, das ilhas, Clazomene e Chipre, mas concede às demais poleis gregas, tanto às pequenas quanto às grandes, a autonomia, exceto Lemnos, Imbro e Sciro. Essas, como antes, pertencem aos atenienses. Eu guerrearei, junto àquele que desejar essas coisas, por terra, por mar, com minhas naus e meus recursos, contra quem

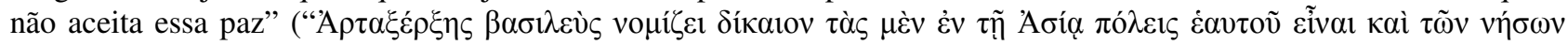

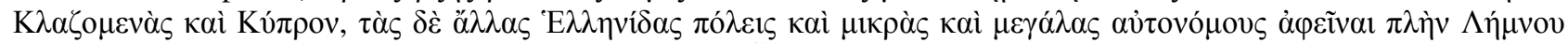

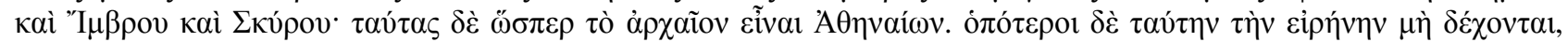

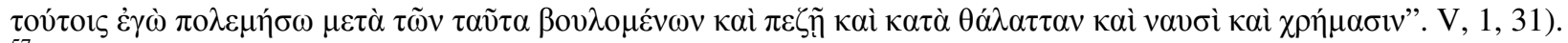

${ }^{57}$ Xen. Hel. III, $2,1$.

${ }^{58}$ Xen. Hel. V, 2, 3.
} 
Mas, se a Paz de Antalcidas é alvo de críticas por não ter sido capaz de fazer cessar as dissensões internas na Grécia, é principalmente pelo tratamento dado aos bárbaros que o acordo é condenável para Isócrates. Pois, sendo uma tentativa de apaziguar a longa hostilidade entre a Grécia e a Pérsia, a Paz de Antalcidas reservava ao rei Artaxerxes II o papel de mediador no acordo, cabendo a ele velar pela paz interna na Grécia. A participação dos persas no acordo foi imposta pelos espartanos como uma forma de alcançar o fim da guerra que lutavam contra o Império; em troca do apoio do rei persa, Esparta concordava em abrir mão das poleis gregas na Ásia, antigo objeto de disputa entre medos e gregos. ${ }^{59}$

Naturalmente, a ocupação das poleis gregas por seus antigos inimigos, os persas, era motivo suficiente para os gregos repudiarem o tratado, mas ultraje maior ainda era sancionar a incursão persa na Grécia, a mesma que um século antes eles haviam tentado invadir, com o pretexto de assim garantir a segurança dos gregos, não sendo surpresa, pois, o tratamento fortemente crítico que Isócrates reserva ao acordo (115-120). ${ }^{60}$

Se os recentes sucessos dos persas tinham feito reavivar a memória das tentativas de ataque à Grécia empreendidas no início do século V a.C., despertando entre os gregos o medo de serem

\footnotetext{
${ }^{59}$ Localizada no sudeste da Ásia Menor, a Jônia estava sujeita aos perigos de ter uma vizinhança composta por tribos nômades e grandes civilizações guerreiras, tendo sido, em diversas ocasiões, alvo dos ataques de povos vindos do leste. Alternando períodos de liberdade com a submissão a povos bárbaros, como os cimérios ou lídios, essa região se encontrava, no início do século V a.C., sob o domínio dos persas; nessa época, o jônio Aristágoras lança um apelo aos gregos do continente para ajudá-los a expulsar os invasores e, tendo conseguido o apoio de Atenas, empreende uma revolta contra o império. A revolta jônia, mesmo com um sucesso apenas temporário (as poleis asiáticas conseguiram manter-se livres somente por pouco mais de cinco anos, de 498 a 493 a.C.), tornou-se um importante episódio dentro da história grega, pois, ocorrendo um pouco antes das invasões persas à Grécia continental, representou um primeiro exemplo de uma união helênica contra a tirania dos bárbaros, estabelecendo assim um precedente para a resistência dos gregos durante as Guerras Médicas.

${ }^{60}$ A Paz de Antalcidas, porém, é referida de forma mais favorável no discurso Sobre a paz: "Afirmo, pois, que é necessário fazer a paz não somente com os quios, ródios e bizantinos, mas com absolutamente todos os homens, e fazer valer os acordos, não esses que alguns recentemente têm esboçado, mas aqueles que firmados entre o rei e os lacedemônios, ordenando que os gregos fossem autônomos e que guarnições se retirem de poleis alheias e que cada um governe a sua própria polis. Pois não encontraremos disposições nem mais justas nem mais vantajosa para a polis do

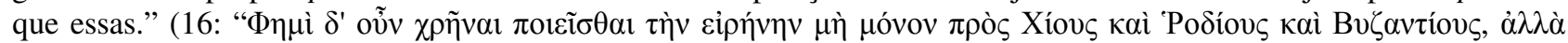

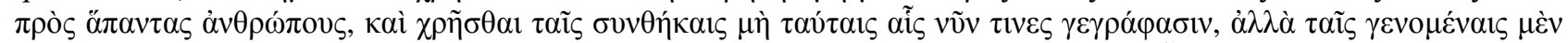

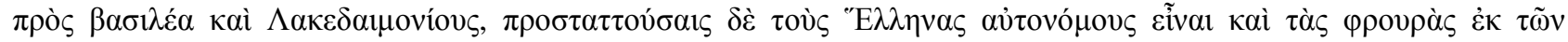

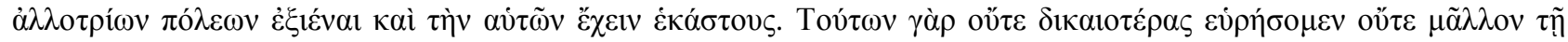
$\pi$ $\delta \dot{\lambda \varepsilon 1} \sigma v \mu \varphi \varepsilon \rho o v ́ \sigma \alpha \varsigma$."). A mudança de postura de Isócrates poderia, portanto, ser creditada ao período dito de guerra social na Grécia: ainda que a datação desse texto seja um ponto controverso entre os filólogos, pode-se afirmar com segurança que o discurso Sobre a paz foi composto depois da desastrosa dissolução da Segunda Confederação Marítima, em 357 a.C., quando as poleis aliadas voltaram-se contra Atenas, sendo que Isócrates não mais podia culpar os espartanos ou qualquer outra polis além da sua própria pelas dissensões entre os gregos.
} 
novamente alvo de uma invasão, os fracassos do rei Artaxerxes II em reprimir insurreições em seu império alimentavam a esperança da conquista helênica da Ásia. O Panegírico cita, por exemplo, as revoltas no Egito e em algumas satrapias a leste como prova da fraqueza do rei e de que era aquela a hora de atacar, antes de os persas pudessem se organizar e melhor resistir a uma incursão helênica. Mais importantes para os argumentos de Isócrates, porém, foram os episódios de resistência protagonizados por gregos no continente asiático, sede do poder do rei: em 399 a.C., tropas lideradas pelo soberano de Esparta Agesilau II (144) conseguem importantes sucessos na Ásia Menor, ocupando territórios anteriormente sob a posse de Artaxerxes.

De especial relevância para o Panegírico, pois, foi a retirada dos dez mil soldados gregos na Pérsia, em 401 a.C. $^{61}$ Para entender tal fato, é necessária uma breve digressão. Após a morte do rei persa Dario II, o trono é legado ao primogênito Artaxerxes; a sucessão, porém, é contestada por Ciro, filho mais novo do rei, que então pretende depor seu irmão. Sendo um tradicional aliado de Esparta, o sátrapa rebelde recorre a essa polis para ajudá-lo na sua empreitada de tomar o império para si, e prontamente é atendido pelas autoridades espartanas, que, além de sua frota, cedem-lhe o estratego Clearco para liderar a tropa de cerca de dez mil mercenários gregos contratados por Ciro. A batalha decisiva dá-se em Cunaxa, ao norte da Babilônia, na qual a superioridade das tropas de Ciro sobre os inimigos é insuficiente para garantir-lhes a vitória, já que a morte de seu comandante na ocasião resolve a disputa pelo trono em favor de Artaxerxes II.

É a partir desse momento que começa o retorno dos gregos da Pérsia, aventura registrada na Anábase por Xenofonte, que foi um dos participantes da campanha de Ciro. Nessa obra, com efeito, o historiador narra que, não obstante enfrentarem a oposição de todo o império persa, esses soldados tiveram sucesso em cruzar a Ásia e chegar ilesos ao Mar Negro, limite do império, onde estavam a salvo das tropas persas. Para muitos gregos, a lição dada pela fuga dos dez mil é que era possível uma campanha vitoriosa na Ásia, sobretudo quando o rei enfrentava oposição interna por

\footnotetext{
61 "Dez mil" é como a historiografia geralmente se refere a este episódio, embora as fontes primárias expressem discordâncias quanto ao exato número dos participantes da expedição (o Panegírico, por exemplo, fala não de dez, mas de seis mil homens). Para maiores detalhes, vd. nota 55 à nossa tradução (p. 144).
} 
conta de sua controversa ascensão ao trono. Já há muito tempo, a fundação de colônias nas bordas do mundo grego servia ao propósito de resolver conflitos internos, deslocando uma parte da população em discórdia para terras despovoadas; dessa forma, na Ásia, os gregos poderiam se aproveitar dos recursos naturais do outro continente, ao mesmo tempo em que aliviavam as tensões internas que opunham os gregos na Europa.

Em suma, ao configurar os eventos históricos dentro do Panegírico, Isócrates esboça um quadro ao mesmo tempo de dissensões internas entre os gregos e de ameaça de uma nova invasão bárbara, fazendo dessa o momento oportuno para um discurso que convocava uma campanha panhelênica contra a Ásia.

\section{c) Fortuna crítica}

O Panegírico pode claramente ser dividido em duas partes principais: precedida pelo proêmio (1-19), em que Isócrates explicita os objetivos do seu discurso, a primeira seção vai do parágrafo 20 ao 128 , e aí se reconhece uma série de tópicos que são também encontrados nos supérstites dos discursos fúnebres; não é surpreendente, pois, que essa seção esteja dedicada a Atenas, especificando o papel que a polis deveria ter na campanha contra a Ásia e descrevendo o passado de glórias de Atenas e pelos muitos benefícios que ela prestou aos demais gregos. Apenas no parágrafo 133 (após uma breve passagem de transição, unindo as duas seções) que Isócrates retorna à proposta anunciada no proêmio como objetivo principal de seu discurso, exortando os gregos a se unirem em uma expedição contra a Ásia. Fechando o Panegírico, os parágrafos 187 a 189 renovam os apelos de que os gregos devem se reconciliar e fazer a guerra contra os bárbaros.

Naturalmente, a ênfase que é dada à seção "ateniense”, na qual se advoga o direito de Atenas a comandar a cruzada pan-helênica proposta por Isócrates, parece trair um viés pró-ateniense do discurso, sendo que, durante muito tempo, o Panegírico esteve no centro de um intenso debate entre os comentadores, tentando saber se o discurso era realmente uma obra de caráter pan-helênico ou 
uma defesa dissimulada de Atenas e seu poder imperial. Os principais protagonistas dessa polêmica foram, de um lado, Werner Jaeger e, do outro, Ulrich von Wilamowitz-Moellendorff. ${ }^{62}$

Esse último defendia ser o Panegírico um panfleto político, dando voz às aspirações de um grupo de cidadãos em Atenas que desejava organizar uma coalizão marítima aos moldes da Confederação de Delos, e o fato de, dois anos após a publicação do discurso, ter se dado a fundação da Segunda Confederação Ateniense, agrupando uma série de poleis em torno de Atenas, era, para Wilamowitz, a prova definitiva da visada abertamente ateniense do discurso. ${ }^{63}$ Essa leitura do Panegírico, porém, tinha a desvantagem de, ao focar-se apenas em uma das grandes partes do discurso, ${ }^{64}$ desconsiderar sua segunda seção, na qual Isócrates tratava da campanha contra a Pérsia. $^{65}$

Jaeger, por outro lado, descartava a tese desenvolvida por Wilamowitz e Drerup: abordando o discurso de modo diferente, não mais de uma perspectiva histórica e política, mas agora a partir do desenvolvimento da paideia grega e das doutrinas pedagógicas da antiguidade, Jaeger situava a obra de Isócrates entre o esquematismo demasiado prático dos sofistas, visando preparar os jovens para o sucesso na vida pública sem, no entanto, preocupar-se com os fins éticos de sua arte, e a aridez do método desenvolvido por Sócrates e seus seguidores, o qual, pretendendo desenvolver uma

\footnotetext{
62 “Isokrates Panegyrikos 100-14”. in: Wilamowitz-Moellendorff: 1985, vol. II, p. 380-90; “Educação Política e Ideal Pan-helênico". in: Jaeger: 2003, p. 1095-110.

${ }^{63}$ Embora a documentação epigráfica esteja sujeita às mesmas suspeitas que se lançam contra as obras literárias, não deixa de ser interessante observar que a Segunda Confederação Ateniense, que explicitamente citava a defesa contra a tirania espartana nos documentos de sua fundação (Tod, M. N. Greek Historical Inscriptions, vol. II, 123), não coincidia exatamente com a proposta do Panegírico de uma união completa entre os gregos contra os bárbaros, uma vez que ela excluía a entrada de poleis sob o domínio persa (Usher: 1990, p. 20).

${ }^{64}$ Como corretamente observou Buchner (1958, p. 4), Wilamowitz centrou sua análise do Panegírico basicamente na seção em que Isócrates faz a defesa de Atenas, comparando o comando exercido por sua polis com o violento domínio espartano da Grécia (100-14). Escapa ao comentador, pois, que essa parte do discurso tinha a finalidade não de propor de novo o domínio que Atenas exercia sobre as outras poleis gregas durante a Confederação de Delos, mas apenas de provar que Atenas, quando esteve à frente dos gregos, não exerceu o comando de forma injusta (ou, ao menos, não tão injustamente quanto os espartanos presentemente o faziam). Dessa forma, não se pode dizer que essa parte do discurso não entra em contradição com o objetivo expresso por Isócrates no início do Panegírico de partilhar a chefia da campanha contra a Ásia entre Atenas e Esparta.

${ }^{65}$ Infelizmente, não nos foi possível o acesso ao artigo de Engelbert Drerup, outra importante contribuição ao debate sobre o Panegírico, a qual dava continuidade à leitura de Wilamowitz ([1895] Epikritisches zum 'Panegyrikos' des Isokrates. Philologus 54, p. 636-53), de forma que tivemos de nos contentar com o resumo que dele faz Masaracchia: "Engelbert Drerup, il quale rese ancora più rigida la tesi wilamowitziana com l'affermare che il progetto della guerra contro i barbari fu da Isocrate ereditato e adottato allo scopo di mascherare il vero e unico obietivo, la restaurazione dell'imperio ateniesi." (1995, p. 53).
} 
educação que tornasse os homens melhores, preconizava o afastamento completo da atividade política. Isócrates, herdeiro de ambas as posições, mas não adotando completamente nenhuma delas, propunha uma educação que formasse cidadãos moralmente bons e aptos para o exercício da vida pública. ${ }^{66}$ Para mobilizar os gregos, no entanto, seria necessário um "grande empreendimento comum, para o qual se deverão agrupar os Estados gregos, será a única coisa que poderá evitar a completa desintegração de Grécia, e com ela a ruína de suas partes". ${ }^{67}$ Dessa forma, para Jaeger, a campanha contra a Ásia tornava-se apenas um motivo, de que Isócrates se apropriara para propor a correta prática da política, a qual ele desejava ensinar aos gregos. ${ }^{68}$

Essas dificuldades, em grande parte, foram solucionadas pelo extenso comentário de Edmund Buchner ao discurso, em obra publicada no ano de $1958 .{ }^{69} \mathrm{O}$ comentador considerava serem duas as principais dificuldades postas pelo Panegírico, a primeira delas relativa ao significado de hègemonia, que, para muitos comentadores, designava a chefia da campanha pan-helênica proposta por Isócrates. A reiterada presença do termo na primeira parte do discurso, ${ }^{70}$ dedicada à exaltação de Atenas, pois, evidenciaria que o verdadeiro intuito de Isócrates ao compor o Panegírico era pleitear comando dos gregos para sua polis natal, visto que um dos propósitos centrais dessa seção é provar que são justas as pretensões atenienses à hegemonia. ${ }^{71}$

\footnotetext{
66 "Platão censurava a retórica por ensinar apenas meios de persuasão, sem ser capaz de apontar nenhuma finalidade, razão pela qual só servia para fornecer aos homens armas espirituais para a consecução dos seus objetivos contrários à moral. [...] Na sua orientação para a ideia pan-helênica viu Isócrates o caminho por onde se podia resolver também este problema. Tratava-se, por assim dizer, de encontrar um meio termo entre a indiferença moral da educação retórica anterior e o critério platônico que consistia em reduzir a política à ética e que praticamente nos fazia voltar as costas a toda a política. A nova retórica tinha de encontrar um objetivo que fosse eticamente defensável e suscetível, além disso, de aplicação política prática." (Jaeger: 2010, p. 1070)

${ }^{67}$ Jaeger: 2010, p. 1069.

${ }^{68}$ Para um sumário bastante equilibrado dessa polêmica e das posições dos principais envolvidos, vd. Masaracchia: 1995, p. 52-55.

${ }^{69}$ Der Panegyrikos des Isokrates: eine historisch-philologische Untersuchung; vd. bibliografia.

${ }^{70}$ Contam-se treze ocorrências da palavra entre os parágrafos 20-133 (20, 21, 22, 25, 37, 66, 71, 98, 99, 100, 103, 122 e

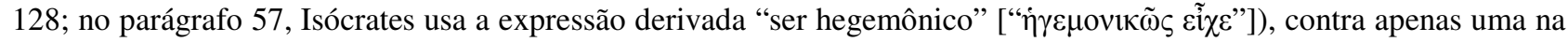
seção final do discurso (166).

${ }^{71}$ Paneg. 20: “...para que fique claro a todos que, no passado, a nossa cidade controlou com justiça o mar e que hoje ela

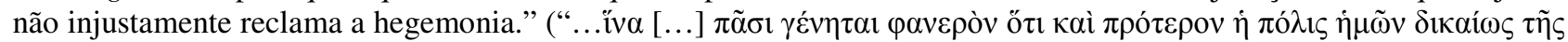

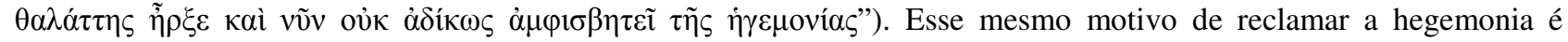

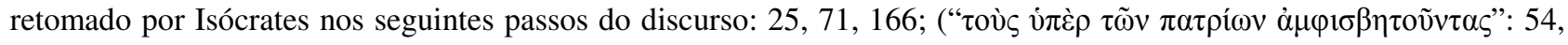
$68)$.
} 
O termo, contudo, aparece no proêmio do discurso (17), dessa vez associado não somente a Atenas, mas também a sua rival Esparta. Fato ignorado pelos demais comentadores, Buchner explica que, nesta passagem, hēgemoniai, em sua única ocorrência no plural em todo o discurso, significa não a liderança absoluta de uma única polis sobre todos os gregos, mas, ao contrário, o comando compartilhado entre as mais fortes entre elas: Isócrates diz que Atenas e Esparta deveriam partilhar ("dielesthai") a chefia da expedição, a primeira devendo estar à frente da frota de naus, enquanto a outra comandaria as tropas terrestres. De fato, esses eram papéis tradicionalmente atribuídos às duas poleis logo após a Guerra do Peloponeso, ${ }^{72}$ e o parágrafo anterior do discurso afirmava que a maior parte dos gregos já estava sob o domínio dessas duas poleis e que a disputa entre elas era o principal obstáculo para a concórdia helênica. Consequentemente, o termo passa a designar, na primeira seção do discurso, quando aparece estritamente relacionado às pretensões atenienses, o possível comando da polis sobre a ofensiva marítima da campanha contra à Pérsia; à Esparta, porém, estaria reservado um papel de chefia semelhante ao de Atenas, ao comandar as tropas terrestres na invasão contra a Ásia.

A segunda causa de confusão para Buchner estava relacionada à archē. Usualmente significando "império, domínio", o termo se referia, na seção ateniense do Panegírico, ao comando que a polis exerceu sobre a Grécia durante a maior parte do século V a.C., mas, ao contrário do que pensaram muitos comentadores, essa palavra não é usada por Isócrates para propor uma retomada do antigo poder ateniense. Assim, quando o autor inclui a palavra na passagem sobre o domínio de Atenas sobre os gregos (100-28), ele não propõe um novo domínio sobre a Grécia por Atenas, mas pretende apenas provar que foi justo o governo anterior da polis, exercido depois das Guerras Médicas. Para tanto, ele contrapõe o domínio ateniense com o de Esparta, provando que esse

\footnotetext{
${ }^{72}$ Atenas possuía a maior frota e, portanto, mantinha o controle militar sobre o mar, enquanto Esparta era o lar dos melhores contingentes terrestres.
} 
cometeu muito mais crimes, enquanto as aparentes violações de Atenas foram necessárias para manter a paz na Grécia. ${ }^{73}$

Por meio da análise cuidadosa de termos-chave ao longo do discurso, portanto, o comentador demonstrou que o Panegírico não poderia ser reduzido à aberta defesa de uma política expansionista de sua polis natal, ainda que o discurso mantenha um evidente viés pró-ateniense. Assim, o Panegírico, a despeito de seu evidente caráter político, não pode ser facilmente assimilado a uma proposta política limitada, como a defesa de uma nova aliança marítima ateniense. Buchner, contudo, a despeito de nos fornecer uma análise bastante precisa do significado das referências políticas no discurso, comete o mesmo erro que Wilamowitz, pois também ele, ao determinar o papel dos atenienses na campanha contra a Ásia, acabe por vincular o Panegírico a um objetivo político preciso. De forma semelhante, para Buchner, a importância do discurso, estando estritamente vinculada ao projeto de campanha contra a Ásia, também se esgotaria no momento de sua publicação, no qual essa proposta ganharia relevância.

Ademais, que o Panegírico propusesse uma partilha de poder entre Esparta e Atenas na campanha contra a Ásia não reduz a clara posição pró-ateniense do discurso. Pleitear o domínio do mar, deixando o comando das forças terrestres ao encargo de Esparta, com efeito, não pode ser simplesmente considerado como fruto de um inocente esforço de conciliação por parte de Isócrates. De fato, o poderio marítimo exercido por Atenas foi sempre visto como uma ameaça pelas demais poleis e, durante as Guerras Médicas, sua numerosa frota servia de apoio à pretensão ateniense de comandar a defesa marítima da Grécia, segundo nos relata Heródoto. Há, com efeito, um episódio das Histórias que é exemplar de como o domínio marítimo ateniense era percebido pelos demais gregos como tendo objetivos menos altruísticos que sua defesa da Grécia contra os bárbaros: narra o autor que, pouco antes da batalha de Artemísio, as outras poleis resistentes recusam-se a aceitar a chefia da frota helênica por um ateniense e afirmam que desfariam a aliança caso se insistisse nessa

\footnotetext{
${ }^{73}$ Buchner: 1958, p. 121-42.
} 
possibilidade (VIII, 2), provavelmente por temerem que Atenas, tão logo derrotasse os persas, aproveitar-se-ia de sua preeminência no mar para tentar controlar poleis mais fracas.

Não se pode negar que tal receio fosse infundado, uma vez que, por meio de sua numerosa frota, Atenas conseguiu impor sobre a Grécia uma política imperialista que durou quase setenta anos, e a Segunda Confederação Marítima prova que as ambições em reconquistar uma parte de seu antigo poder não tinham sido descartadas por muitos atenienses. Sendo assim, a proposta "panhelênica" do Panegírico não exclui o domínio de Atenas sobre as outras poleis nem que o discurso tivesse um objetivo hegemônico; pelo contrário, o justifica, uma vez que a defesa da Grécia contra os bárbaros era usado por Atenas para justificar seu domínio sobre as demais poleis. $^{74}$

\footnotetext{
${ }^{74}$ A solução de considerar o discurso como resultado de dois períodos diferentes de composição seria ainda defendida por alguns comentadores (como Usher: 1990), considerando que uma primeira versão do discurso teria sido composta em 390 a.C., ou seja, após a batalha de Cnido (392 a.C.), quando a derrota marítima dos espartanos prejudica suas chances de domínios sobre os demais gregos. A primeira grande seção do Panegírico, atancando os espartanos, pois, teria sido composta nesse periodo ("A starting-date around 390 B.C., which seems probable, coincides with a period of revival for Athenian imperial ambitions, when the idea of a Panhellenic expedition against Persia under the joint leadership of Sparta and Athens might have seemed realistic.") A Paz de Antalcidas, segundo essa linha de interpretação, marcou um segundo momento na composição do Panegírico, quando a aliança espartana com o Império Persa tornaria impossível a Atenas, ao menos em um futuro próximo, recuperar sua autonomia sobre a Grécia. De forma que Isócrates, nesse momento, teria abandonado o objetivo inicial do Panegírico de ser um panfleto contra os espartanos, agora convidados pelo autor a se aliar a Atenas contra os persas ("The King's Peace (386 B.C.) was in effect an agreement between Persia and Sparta which defined their respective spheres of influence. Sparta, far from contemplating alliances with other Greek states against Persia, used the ascendancy she had gained from the people to subdue her neighbours, and, in accordance with its terms, abandoned the Asiatic Greeks kinsmen.” Usher: 1990, p. 19). Essa leitura é uma versão da proposta de duas edições feita por Engel (vd. n. 26 da primeira seção deste capítulo, p. 15) e, embora as datas não coincidam exatamente, está sujeita as mesmas críticas feitas àquela teoria, de que as principais seções do discurso teriam sido o resultado de dois momentos distintos de redação. Não somente nossa ignorância sobre o processo de composição de Isócrates nos impede de fazer tais afirmações, mas caberia ainda questionar, se realmente adotássemos essa hipótese, a conveniência de se juntar dois discursos diferentes - um contra Esparta, outro contra os persas -, em uma só peça, advogando objetivos contraditórios.
} 


\section{2 - Gregos e bárbaros no Panegírico}

\section{a) A oposição entre gregos e bárbaros}

É importante notar, na proposta inicial do Panegírico, a estreita dependência que há entre os dois objetivos iniciais que Isócrates diz ter-lhe motivado a compor o discurso: para fundamentar seu apelo de união entre os gregos, o autor busca encontrar alguma característica comum partilhada por todos aqueles que se identificassem como helenos. ${ }^{1}$ Em meio a essa diversidade, no entanto, podemos encontrar na língua que todos eles igualmente falavam um primeiro elemento característico, possibilitando a comunicação entre eles. É verdade que os diferentes dialetos da língua grega antiga alertavam para a existência de grupos particulares dentro do povo heleno, dividido em três grandes grupos linguísticos, os jônios, os dóricos e os lésbio-eólicos, e ainda incluindo grupos regionais como os coríntios. ${ }^{2}$ A despeito dessas diferenças, porém, a língua ainda era o elemento comum a distinguir os gregos de todos os outros povos, como indica a palavra pela qual os helenos os designavam - "barbaros" - originalmente uma onomatopeia reproduzindo os grunhidos incompreensíveis com que os gregos ouviam os bárbaros se comunicarem. ${ }^{3}$

É justamente nessa alteridade, inicialmente linguística, estabelecendo a distinção dos gregos com os outros povos, que Isócrates encontrará o elemento comum a motivar sua cruzada panhelênica contra a Ásia. No Panegírico, com efeito, a relação entre esses dois povos é retratada como sendo a de um antagonismo absoluto, referindo-se o discurso à inimizade como a atitude mais natural dos gregos em relação aos bárbaros (echtra: 73, 157). O discurso apresenta a hostilidade em

\footnotetext{
${ }^{1}$ A "arqueologia" de Tucídides (I, 3) é testemunho de que os gregos tinham consciência de que, historicamente, não constituíam um grupo homogêneo, mas que, em tempos antigos, diversas populações ocupavam a Hélade, cada qual se identificando como um povo único e distinto, já que não possuíam um nome comum que as designasse (prova disso seria a épica homérica, que, ao designar os participantes das campanha contra Troia, o faz como argivos ou dânaos, sendo que a designação de "helenos" estava reservada apenas para os habitantes de uma pequena parte da Grécia: os companheiros de Aquiles). Segundo o historiador, a designação comum foi-lhes dada em razão do chefe de uma dessas tribos, Heleno, que, graças a seu crescente poder, garantiu a proteção aos ocupantes mais fracos da Grécia, e, com o tempo, todos também passaram, por assimilação, a ser chamados de helenos.

${ }^{2}$ Colvin: 2010, p. 200: "The history of Greek from the introduction of the alphabet until the Koine is the history of the dialects. In the Archaic and Classical periods the Greek language is an abstract notion in the sense that there was no standard language, but a collection of dialects that we think were mostly mutually intelligible."

${ }^{3}$ Chantraine: 1969 , p. 165: “ $\beta \alpha ́ \rho \beta \alpha \rho \varsigma$ désigne l'étranger en tant qu'il parle une langue étrange et balbutiante, que l'on ne comprend pas. [...] Il s'agit d'une formation fondée sur une onomatopée."
} 
relação aos bárbaros como resultado das injúrias que esses empreenderam contra a Grécia, a exemplo das tentativas de invasão à Europa pelas amazonas e trácios.

Mais significativo, porém, que, para ele, um dos objetivos da paideia fosse cultivar nos gregos esse afeto: assim, segundo Isócrates, os antigos cidadãos de Atenas e Esparta deveriam ser honrados porque eles tornaram seus descendentes "implacáveis adversários dos bárbaros", 4 preparando-os para, mais tarde, repelirem as invasões persas à Grécia. Do mesmo modo, Isócrates afirma que a grande reputação de Homero deve-se a ter ele "elogiado bem os que guerrearam contra os bárbaros" e que esse foi o motivo de obras suas serem ensinadas aos meninos, para que, "ao escutarmos muitas vezes seus versos, aprendamos a longa inimizade que temos contra aqueles homens, e para que desejássemos emular a virtude dos que fizeram campanha contra a Ásia e realizar as mesmas façanhas que aqueles homens." ${ }^{5}$ A associação entre paideia e o ódio aos bárbaros, ademais, é significativa, porque assim podemos melhor caracterizar a ênfase política que Isócrates atribuía à atividade de professor, uma ocupação que ele mesmo dizia ter exercido durante sua vida. ${ }^{6}$

Mas, assim como acima questionamos a unidade do povo helênico (o qual estava dividido seja pela geografia, seja pelos dialetos, não podendo ser automaticamente assimilado a um grupo homogêneo como nos quer fazer entender Isócrates), é mais justificado ainda que questionemos o uso que Isócrates faz de "bárbaro". Conforme dissemos anteriormente, o termo designava todo homem que não fosse grego, englobando as numerosas populações com as quais os gregos tinham contato. No Panegírico, porém, "bárbaro" é utilizado quase que exclusivamente como uma metonímia para um único povo: os persas. Masaracchia, como efeito, notou que, "[n]el corso del

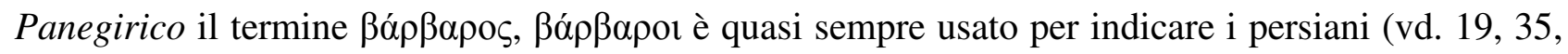

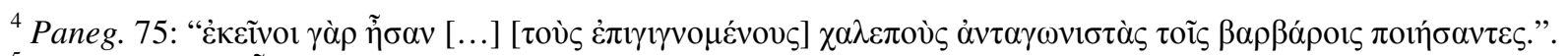

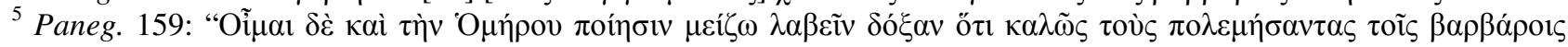

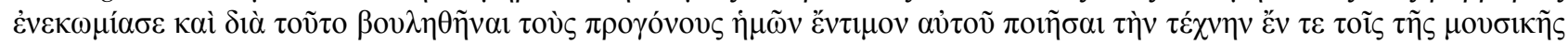

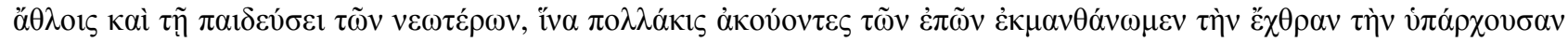

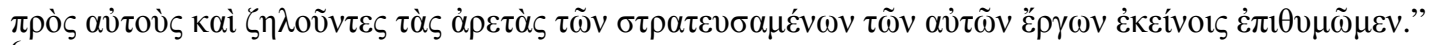

${ }^{6}$ Antíd. 193. vd. p. 13 et seq. de nosso estudo.
} 
$99,117,128,131,136,161,164,175,177,178,185)$. Sono rari i casi in cui esso designa popoli che si trovano fuori dell'imperio persiano."7

É natural a escolha que Isócrates faz dos persas como antagonistas dos gregos no Panegírico. Em primeiro lugar, porque a ameaça representada pelo império persa já havia motivado o fim das hostilidades na Grécia, havendo diversas ocasiões em que os gregos ignoraram suas diferenças e se aliaram para combater seu inimigo comum, representado pelo império persa. De fato, as tentativas de invasão da Grécia empreendidas por Dario e, mais tarde, por seu filho Xerxes, tiveram um papel relevante em sedimentar a solidariedade pan-helênica, forçando os gregos a cooperarem na resistência contra os persas. Mesmo com o fim das Guerras Médicas, o temor de novas agressões perdurou e motivou diversas poleis a se unirem para organizar alguma forma de defesa contra seus vizinhos a leste, um esforço que culminou na fundação da Confederação de Delos.

Esses ataques tiveram um profundo impacto no imaginário helênico. Até as Guerras Médicas, a Grécia era o palco de muitos conflitos, mas estes consistiam em dissensões entre os próprios gregos e seu alcance não ultrapassava o âmbito regional, não havendo, assim, uma potência que pudesse impor a todos os gregos seu comando. A situação muda radicalmente, porém, quando Dario decide empreender uma campanha contra a Europa, pois, naquele momento, os persas já dominavam grande parte da Ásia Menor e o Egito, sendo real o perigo de que, se vitoriosos, a Grécia fosse anexada a seu império. A consequência mais imediata para os gregos do surgimento do império persa era a perda da liberdade política, algo que os habitantes da Jônia, região grega no sudoeste da Ásia, já experimentavam. ${ }^{8}$

A questão da perda da liberdade era agravada pela organização política típica entre os persas, pois, para os gregos, o fato de que um único tivesse poder sobre tantos povos inclinava os persas à servidão, sendo eles um povo de escravos. É verdade que não faltavam, na Grécia, os tiranos, mas,

\footnotetext{
${ }^{7}$ Masaracchia: 1995, p. 57, em um número de ocorrências levemente menor do que as de Пદ́pбaı (67, 57, 140, 145, 146, 161, 168; Пєрбıкòs: 68, 158) no mesmo discurso.

${ }^{8}$ Para maiores detalhes, vd. a nota 59, p. 28, do primeiro capítulo deste estudo.
} 
quando comparados com os persas, os gregos viam a si mesmos como homens livres, de forma que o receio de tornar-se súditos de tal homem fortalecia a resistência dos gregos à dominação persa.

Alguns episódios relatados por Heródoto em suas Histórias - obra que trata das Guerras Médicas - são exemplares dessa oposição que os gregos faziam entre sua própria liberdade e a servidão entre os persas. Assim, no Livro VII, o comandante persa Hidanes tenta conseguir o apoio de Esparta ao império, dizendo as inúmeras vantagens que lhes adviriam dessa aliança; os espartanos rejeitam essa proposta, porém, com a seguinte afirmação: "Pois sabes bem o que é ser escravo, mas nunca experimentaste a liberdade, nem se é algo doce ou não. Pois, se a tivesses experimentado, nos aconselharias a lutar por ela não só com lanças, mas também com machados."9 Os atenienses também são tentados com a aliança à Pérsia, mas, do mesmo modo que os espartanos, eles se recusam a perder sua liberdade para os bárbaros: "Nós, de fato, sabemos que [o rei persa] é muito mais poderoso do que nós; não obstante, porque amamos a liberdade, a defendemos de todos os modos que formos capazes". ${ }^{10}$

Essa oposição entre a liberdade dos gregos contra a servidão persa é importante para o nosso objeto de estudo, porque ela será explorada por Isócrates como forma de fundamentar a campanha helênica contra Ásia no Panegírico. Os parágrafos 150-51, com efeito, procedem a uma descrição do império persa, lançando um olhar sobre a organização política que lhe é característica, na qual o poder sobre tantos povos estava confiado a um único homem:

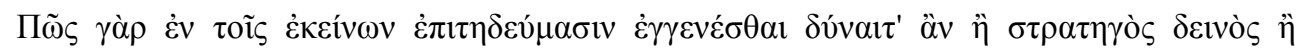

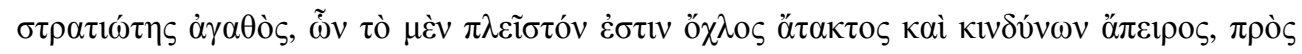

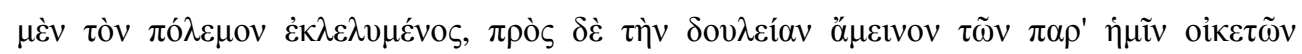

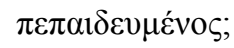

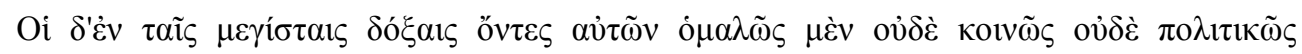

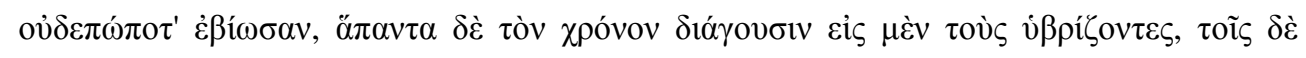

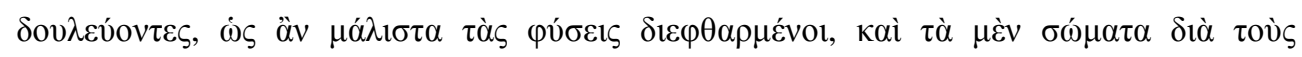

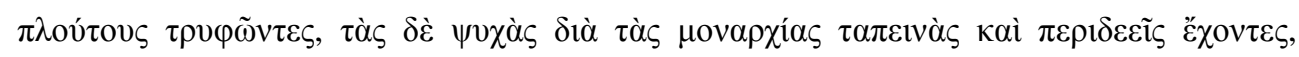

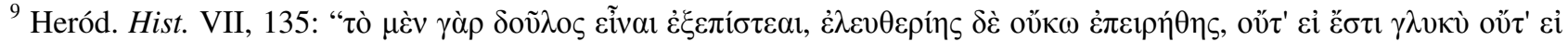

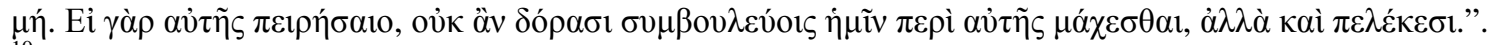

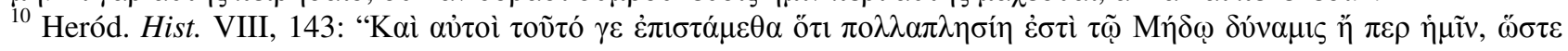

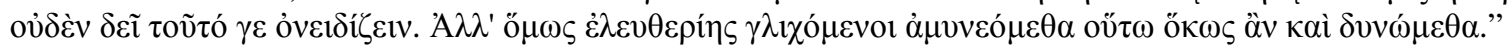




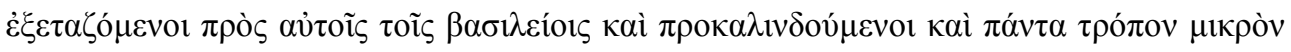

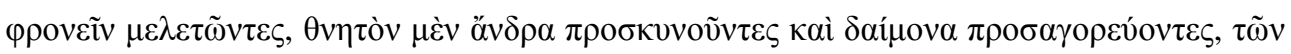

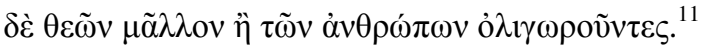

Pois como se poderia produzir um estratego habilidoso ou um bom soldado em suas instituições, cuja maior parte é uma multidão desordenada e inexperiente dos perigos, imprestáveis para o combate e melhor educada para a escravidão do que os nossos escravos domésticos?

Os de maior reputação entre eles, sem exceção, nunca viveram em igualdade nem como cidadãos, mas passaram todo o tempo sendo arrogantes com uns, mas escravos de outros, de modo que a natureza humana pode ser completamente corrompida, aos corpos por meio da riqueza tornando efeminados; tendo as almas, por meio do governo monárquico, submissas e amedrontadas. Perfilados em frente aos próprios palácios, prostram-se aos pés do rei e praticam todo tipo de humilhações. E obedecem a um simples mortal, dirigindo-se a ele como a uma divindade, mostrando maior desprezo pelos deuses que pelos homens.

Deve-se primeiramente notar que a passagem segue imediatamente após o relato de Isócrates sobre os recentes fracassos militares dos persas, citando as revoltas contra o rei nas diversas províncias e concluindo com a fuga dos dez mil gregos da Ásia, prova da superioridade helênica sobre seus inimigos. Em seguida, portanto, tenta-se dar uma explicação para as derrotas sofridas pelos exércitos do rei, a qual o autor encontrará no modo como os persas eram governados. Obviamente, esses revezes não eram sinal da fraqueza militar do império, cujo poderio assegurava a dominação sobre um vasto território, e os numerosos contingentes e recursos a sua disposição punham um obstáculo considerável a um ataque externo. Isócrates, porém, a fim de tornar mais atrativa sua proposta de ataque a inimigos tão fortes, atribui tais resultados à moleza ("malakia"), que o autor diz ser própria dos persas. ${ }^{12}$

A estratégia do autor aí consiste, portanto, em relacionar essa moleza à falta de liberdade entre os persas. Assim, se ao império faltam soldados competentes, isso é consequência da servidão absoluta a que eles estão submetidos, uma vez que, para os gregos, a guerra uma atividade nobre, sendo exercida pelos homens de maior distinção nas poleis. É importante observar que, na Grécia, o

\footnotetext{
${ }^{11}$ Paneg. 150.

${ }^{12}$ Paneg. 149: "Julgo, assim, que em absolutamente todos os lugares a moleza dos persas tem se mostrado." (" $\Omega \sigma \tau \varepsilon \mu$ oı

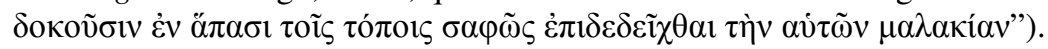


serviço militar era geralmente um encargo que advinha com a aquisição da cidadania, ${ }^{13}$ sendo um dos deveres do cidadão defender a polis da qual ele fazia parte.

As posições militares, ademais, não somente eram uma prerrogativa dos cidadãos, mas muitas vezes elas também eram sinais de nobreza e da participação nos estratos mais altos da hierarquia social. As poleis, com efeito, geralmente não empregavam seus próprios recursos para armar e treinar seus cidadãos, e os custos do treinamento militar dos meninos restavam a cargo da família. Naquele período, a preparação militar exigia, portanto, recursos bastante vastos, uma vez que a principal figura nas batalhas era o hoplita, o soldado de infantaria portando armadura pesada, tendo pouca importância militar os combatentes leves, seja na infantaria, seja na artilharia. Como afirma Sage, a preferência por esse tipo de formação poderia ser resultado não apenas de suas vantagens estratégicas, mas era uma maneira de manter o controle político nas mãos de um estrato da sociedade. ${ }^{14}$ Isso se torna particularmente claro pelo uso de cavalaria entre os gregos, uma posição de pouca utilidade na Grécia, devido a seu terreno montanhoso e acidentado, de forma que, em muitos casos, ${ }^{15}$ sua existência só se justificava como forma de introduzir uma posição aristocrática dentro dos exércitos, uma vez que o treinamento em equitação e era uma atividade particularmente custosa. $^{16}$

Retornando ao Panegírico, essa nobreza que a atividade militar adquiria entre os gregos, pois, contrastava com o tratamento a que o rei submetia "os de maior reputação entre eles" (150), os

\footnotetext{
${ }^{13}$ Sage relaciona a expansão da cidadania com a obrigação de prestar o serviço militar: "That government [polis] took the form first of an aristocracy which gradually expanded the limits of citizenship to include other property owners as well. The proportion varied from place to place, but in all instances it involved the obligation of military service." (Sage: 1996, p. xvi-xvii).

14 "The cost of the equipment for the hoplite limited the segment of the population that could fight. This may have been at least in part purposeful. It was an excellent method of limiting participation without explicit rules for doing so. There was little use of native light-armed troops until the late fifth and early fourth century except in a supporting role, and this may have had a political as much as a technical purpose given the typical equation between full citizen and warrior." (Sage: 1996, p. xviii)

${ }^{15} \mathrm{Na}$ Beócia e na Tessália, porém, o uso da cavalaria tinha maior utilidade, devido às vastas planícies e pastos que compunham sua geografia. Essas regiões, com efeito, eram famosas entre os gregos pelos seus cavaleiros (Tessália: Plat. Meno 70a5-b2, Leis 675d; Boécia: Tuc. IV, 72, Xenof. Hip. 7, 3).

16 "The nexus of birth and wealth that it [cavalry] represented meant that it kept the aristocratic connections with the horse that had been traditional. But it was of limited effectiveness on the battlefield. The physical limitations of the Greek horse, the absence of saddles and stirrups meant that it could not develop into a shock cavalry. Its role on the battlefield was secondary. It major employment was in reconnaissance and especially in the pursuit of infantry whose phalanx had been broken. Occasionally it could inflict heavy casualties on infantry in open order, but it could not ride down infantry in formation." (Sage: 1996, p. xviii).
} 
quais nunca haviam exercido a política, enquanto, na Grécia, essa era, em muitos casos, um privilégio das classes militares. Dessa forma, prossegue Isócrates, não somente a Pérsia não dispõe de bons soldados, mas é também incapaz de produzir bons comandantes (150). Podemos concluir, a partir da descrição que o autor faz do império, que a falta de bons comandantes entre os persas era causada pela subserviência que deviam mostrar diante de seu soberano, ao qual eles deviam mostrar completa obediência, tratando-o como um deus (151). Em contrapartida à humilhação diante de seu senhor, os comandantes persas tratavam com extrema crueldade os subordinados, deles fazendo maus combatentes.

Mas a diferença entre escravos e homens livres quanto à guerra é ilustrada de forma ainda mais clara por uma anedota relatada por Heródoto: conta o historiador que, quando os escravos dos citas se revoltaram, seus senhores tentaram dominá-los usando suas armas, mas que essa era uma estratégia ineficaz, já que a vitória não lhes seria benéfica, fazendo-os perder muitos de seus servos. Como solução ao impasse, um dos citas propõe que os combatentes abandonem as espadas e arcos, e peguem seus chicotes, pois, em suas palavras, "todo esse tempo, eles nos têm visto portando armas contra eles, e pensam ser semelhantes a nós e filhos de homens semelhantes a nós, mas, quando nos virem portando chicotes ao invés de armas, aprenderão que são nossos escravos e saberão que não podem resistir"; ${ }^{17}$ a proposta é aceita e os escravos são derrotados. Essa história é particularmente reveladora por estabelecer uma diferença entre os homens livres e escravos que determina o sucesso dos primeiros na guerra.

Importante também é notar que, no relato de Heródoto, a diferença entre os citas e seus escravos é congênita (“eles pensam ser filhos de homens iguais a nós”), e que, portanto, eles nunca conseguirão vencer seus senhores porque eles têm, usando uma terminologia isocrática, uma natureza ("physis") inadequada à guerra. Essa era, segundo Isócrates, uma das características a determinar o sucesso ou fracasso em alguma atividade, sendo, ademais, possível alcançar tais

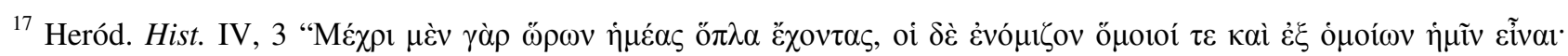

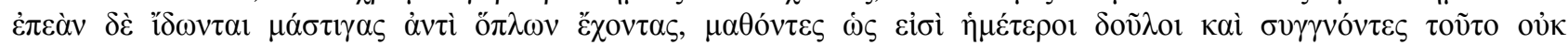

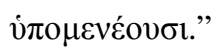


resultados também pela prática ("emperia") e pela educação ("paideia"). ${ }^{18}$ Sendo assim, é significativo nos parágrafos acima citados do Panegírico é o autor caracterizar a escravidão dos persas, responsável pela moleza deles na guerra, como efeito da paideia normalmente praticada no império. $\mathrm{O}$ autor, com efeito, utiliza, na descrição do império persa, três vezes termos relacionados à educação: os verbos trephō e paideuō aparecem no parágrafo 150, enquanto que o parágrafo 152, mais à frente menciona a paideusis recebida no império. ${ }^{19}$ Nessas passagens, por óbvio, Isócrates não se refere a um sistema formal de ensino, mas simplesmente ao meio em que os jovens persas eram criados e que, no caso, é causa de eles serem, segundo o autor, mais fracos que os gregos.

O paralelo que podemos fazer com essa passagem encontra-se nos parágrafos $75-82$, já mencionados anteriormente, nos quais se faz um elogio dos homens que viveram antes das Guerras Médicas, ou seja, os pais dos homens que derrotaram os exércitos invasores de Dario e Xerxes. Isócrates, pois, atribui à geração anterior os sucessos desses homens em batalha, pela preparação que eles deram a seus filhos. Assim como no caso dos persas, cujas práticas ("epitédeumata") faziam com que fosse impossível surgir qualquer guerreiro de valor no império (150), o autor não menciona o treinamento militar que os gregos receberam, mas considera que seus sucessos militares são devidos tão somente aos costumes ("êthe") nos quais eles foram educados que eles conseguiram a vitória (82).

Sendo assim, Isócrates estabelece a educação moral praticada entre os gregos como a causa de seus sucessos militares e de sua derrota sobre os persas, vinculando, portanto, a atividade que ele mesmo exercia ao sucesso nas guerras. Que o autor não mencione, em nenhuma dessas passagens, qualquer sistema pedagógico formal, ademais, não reduz a aproximação que podemos fazer entre esses dois trechos e a própria atividade por ele desenvolvida, uma vez que Isócrates rejeitava, em

\footnotetext{
${ }^{18}$ Contra os Sof. 17-18; Antíd. 186-92.

19 “...os que vão para o mar, chamados sátrapas, não desonram a educação de lá, mas permanecem nesses mesmos costumes, não sendo confiáveis para os amigos, mas agindo de forma covarde para com os inimigos.” (“...oi

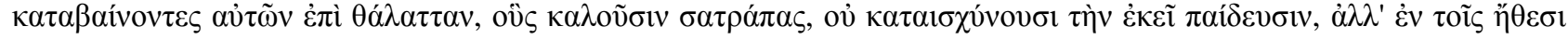

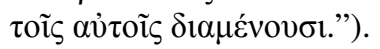


seus discursos, reduzir a educação a um conjunto de regras que deviam ser rigidamente seguidas, como no caso das technai escritas pelos sofistas. ${ }^{20}$

Mas essas passagens espelham também a concepção educativa de Isócrates por relacionarem a paideia à formação moral dos jovens, um dos objetivos que o autor desejava alcançar como professor. Com efeito, foi mostrado anteriormente que, para Isócrates, uma das tarefas do educador era fazer de si mesmo um exemplo moral para os alunos, de forma que eles pudessem modelar sua conduta de acordo com a do seu professor. ${ }^{21}$

Podemos aliar essa informação ao parágrafo 50 do Panegírico, no qual o autor afirma que é a paideia a principal característica distintiva dos gregos, mais do que a physis, ou seja, os laços de sangue comuns que por acaso haveria entre eles. ${ }^{22}$ Dessa forma, a educação, responsável pela identidade helênica dos gregos e, portanto, da diferença entre eles e os persas e demais bárbaros, determina sua superioridade sobre seus inimigos da Ásia, porque lhes confere os costumes que os tornam combatentes superiores na guerra. ${ }^{23}$

\section{b) As panegírias}

O intuito agregador do Panegírico transparece no próprio título do discurso, nomeado segundo as panegírias, os grandes festivais pan-helênicos. Esses eventos constituíam um dos marcos fundamentais para a construção de uma identidade helênica, ao oferecer uma ocasião para pessoas que se identificavam como gregas se encontrarem e reconhecerem os laços de uma herança comum por elas compartilhada. Vencia-se assim a dispersão geográfica entre os gregos, os quais, em

\footnotetext{
${ }^{20}$ Para maiores detalhes, vd. p 18 et seq.; p. 54 et seq.

${ }^{21}$ Cont. os Sof. 17-18; vd. o capítulo anterior, p.

${ }^{22}$ Paneg. 50: "ela [Atenas] fez com que o nome dos gregos parecesse não mais à raça, mas à inteligência pertencer, e fez com que sejam chamados de gregos mais os que partilham da nossa educação do que da natureza comum." (" $\tau$ ò $\tau \tilde{\omega} v$

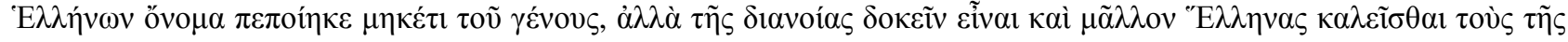

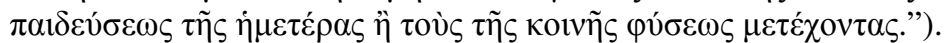

${ }^{23}$ Não se deve deixar de observar que os ataques lançados contra os bárbaros no Panegírico repercutem no tratamento que aí Isócrates reserva aos espartanos. Vimos, com efeito, na seção reservada aos erga (p.), que um dos fatores para a vitória espartana na Guerra do Peloponeso e o subsequente domínio lacedemônio sobre a Grécia foi a aliança com o Império Persa, que forneceu a Esparta os recursos necessários para a formação de sua frota. Atenas, por outro lado, conduziu, na maior parte dos séculos V e IV a.C., uma mais consistente política antibárbara. Dessa forma, nos parágrafos 100-114 do Panegírico, em que Isócrates procede à acusação do domínio espartano sobre a Grécia, a descrição do rude tratamento dos hilotas, os gregos originários do Peloponeso, mas reduzidos à escravidão pelos espartanos, repercute o tratamento dado aos cidadãos na Pérsia, escravos em sua própria terra.
} 
sucessivas ondas migratórias, estabeleceram uma intensa presença por todo o Mediterrâneo, estendendo os limites do mundo grego do Bósforo até o Egito, da Sicília e Península Itálica até a Ásia Menor. Por esse motivo, as quatro panegírias eram consideradas as datas mais importantes do calendário helênico, o qual os gregos consideravam ter tido início com o estabelecimento do primeiro desses festivais, os Jogos Olímpicos de 776 a.C. ${ }^{24}$

Os gregos não estavam separados somente pela geografia, mas a independência política com que se governavam também era um fator de desagregação: sem estarem submetidos à autoridade central de um estado soberano, que incluísse todos eles como membros de uma mesma comunidade, os gregos estavam divididos em unidades políticas autônomas, as poleis. Independentes umas das outras, não raro a disputa por território, recursos naturais ou mesmo o desejo de conquistar maior poder sobre os outros opunha os gregos entre si, havendo um permanente estado de tensão dentro da Grécia, sempre com o perigo de duas poleis rivais guerrearem entre si. Dentro desse quadro, as panegírias intervinham como um momento de paz entre os gregos. Durante os dias de celebração, era decretada uma trégua, portanto, para que eventuais conflitos não pudessem atrapalhar o afluxo a esses festivais, e não poderia haver melhor momento para apresentar um discurso aconselhando a concórdia entre os gregos do que os dias em que ocorriam os jogos: em nenhuma outra ocasião se poderia encontrar tão grande número de gregos reunidos em um mesmo lugar como nas panegírias, não surpreendendo que Isócrates, ao desejar lançar um apelo de união a todos os gregos, tenha escolhido nomear tal discurso de Panegírico.

Mas os Jogos Olímpicos adquiriram sua enorme importância não somente por imporem um intervalo aos constantes conflitos na Grécia e assim constituírem um espaço onde se poderiam apaziguar as eventuais inimizades; eles também operavam um mecanismo que reforçava a identidade helênica pela exclusão do que não fosse grego. Com efeito, não se pode negar que, mesmo antes das conquistas de Alexandre, havia um intenso contato entre gregos e bárbaros, sendo,

\footnotetext{
${ }^{24}$ A contagem retrospectiva das olimpíadas aponta para esse ano (a centésima edição dos jogos ocorreu em 380 a.C., e, já que eles eram realizados quadrienalmente, o primeiro festival deve ter sido realizado em 776 a.C.), embora não possamos estar certos dessa hipótese, uma vez que não restam evidências arqueológicas sobre a origem dos festivais. Para maiores detalhes, vd. Instone: 2007.
} 
por exemplo, bem conhecido o comércio realizado com os fenícios e egípcios (como parece provar Naúcratis, colônia grega situada no delta do Nilo, servindo de base para operações comerciais).

Interessante ainda para considerar a relação entre gregos e bárbaros é a tese proposta por Walter Burkert. ${ }^{25}$ Segundo o estudioso, a Grécia do período anterior às Guerras Médicas recebia uma série de profissionais oriundos da Ásia. Não se tratava de trabalhadores comuns, mas de especialistas, que tinham o domínio em disciplinas específicas: na medicina, na adivinhação e na música. Dessa forma, havia, naquela região do Mediterrâneo, um intenso tráfego de pessoas, que tivera uma importância muito grande no desenvolvimento da sociedade helênica, uma vez que eles não apenas prestavam serviços aos gregos, mas foram também seus professores, ensinando-lhes seus ofícios.

Segundo essa tese, pois, seria normal a presença em Olímpia desses viajantes, que, estando próximos ao templo no momento das celebrações, desviavam de seu caminho para assistir às festividades; participar das competições, porém, era uma honra reservada exclusivamente aos gregos. Heródoto, de fato, conta que, para competir nos Jogos Olímpicos, o rei macedônio Alexandre I fora obrigado a provar sua ascendência helênica, e que sua participação somente fora permitida após ele demonstrar que sua linhagem tinha origem no argivo Pérdicas, um descendente de Héracles $(\mathrm{V}, 22){ }^{26}$

Ainda que o Panegírico visasse exclusivamente à leitura, nunca tendo sido pronunciado por Isócrates nos Jogos Olímpicos, a associação que o autor estabelece com as panegírias é um dado significativo. Da mesma forma, ao compor um discurso denominado Areopagítico e ficticiamente situá-lo no conselho Atenas, o autor explicitava que aí trataria das questões internas da polis. Ao estabelecer um elo com as panegírias, porém, Isócrates não apenas determinava o assunto de que

\footnotetext{
25 Desenvolvida no livro Die orientalisierende Epoche in der griechischen Literatur und Religion (1984; vd. bibliografia).

${ }^{26}$ Séculos mais tarde, a aceitação dos romanos no mundo grego se dará pela participação de Roma nos Jogos Ístmicos, em 228 a.C. (Bandinelli: 1970, p. 26: "Finally, in 228, Romans were granted permission to compete in the Isthmian Games at Corinth - which meant, in effect, election to the closed society of those nations nurtured on Greek civilization.”). É verdade que, no século III a.C., os costumes helênicos já não eram uma exclusividade daqueles que se identificavam como tal, mas haviam sido adotados pelos povos conquistados por Alexandre; ainda assim, é significativo que as panegírias tivessem a autoridade para determinar quem era e quem não era grego.
} 
iria tratar em seu discurso, a saber, a união dos gregos e a guerra contra os bárbaros, mas também fornecia uma indicação da audiência à qual desejava que o Panegírico atingisse, isto é, todos aqueles que poderiam considerar a si mesmos como gregos.

Essa não era, porém, uma estratégia original de Isócrates, havendo demais discursos que aparentemente se situavam em uma panegíria para advogar a união dos gregos contra um inimigo comum, de forma que os comentadores estipularam, a partir da existência desses textos, que havia um gênero de discursos "panegírico" na antiguidade. Essa será, portanto, a questão que trataremos no capítulo seguinte. 


\section{3 - O Panegírico e os discursos Olímpicos}

Como atrativos aos visitantes, as panegírias ofereciam competições atléticas ou musicais, ${ }^{1}$ ao lado das cerimônias religiosas, relembrando a possível origem cultual desses eventos. ${ }^{2}$ Mas, junto a essas atividades, estudiosos da antiguidade presumem que as panegírias também acolhessem apresentações de oradores, ainda que as listas dos vitoriosos não contenham premiações para discursos (indicando que a oratória não fazia parte das competições oficiais desses jogos). Ainda assim, a suposta existência de discursos nas panegírias, pois, não poderia ser ignorado em um estudo sobre o Panegírico: ainda que não tenha sido apresentado ao público em tal ocasião, por mimetizar a fala dos oradores em um festival, o texto retomaria os tópicos e questões tratadas pelos predecessores de Isócrates.

Se essas suposições estiverem corretas, elas fornecem um subsídio importante para o entendimento do Panegírico, pois, mesmo que ele não tivesse sido realmente pronunciado em um festival, poderia haver uma relação com esses precursores, visto que assim Isócrates se apropriaria dos tópicos desenvolvidos pelos oradores nas panegírias para compor seu próprio discurso. Quando confrontamos as evidências a justificar tais juízos, porém, damo-nos conta de que elas nos dizem menos do que quiseram entender seus intérpretes na modernidade. Na verdade, não podemos ter certeza de que oradores se apresentavam regularmente nas panegírias, uma vez que as listas dos

\footnotetext{
${ }^{1}$ As competições musicais eram uma particularidade dos Jogos Píticos, celebrados em Delfos para honrar Apolo, divindade associada com a poesia; para maiores detalhes, vd. a nota 1 (p. 129) à nossa tradução.

${ }^{2}$ A origem das panegírias, para os gregos antigos, estava relacionada à ação de algum deus, Héracles, no caso dos Jogos Olímpicos e Nemeus; Apolo, nos Píticos; e Posseîdon, nos Ístmicos (vd. Davies: 2007, p. 66-67). Mais importante, contudo, é constatar que talvez os próprios jogos tenham nascido de cerimônias religiosas: Instone (2007, p. 75), em texto sobre as origens dos Jogos Olímpicos, sugere que, dentre os fatores determinantes para o surgimento do festival, estava a associação muito estreita entre o culto das divindades e a competição atlética. Como provas, há o registro de que, em alguns festivais do período clássico, atividades como corrida faziam parte das práticas religiosas do culto aos deuses: "Running is a feature of Greek festivals even when not part of formal athletics competitions. The Karneia festival had grape-runners, staphylodromoi: a runner is deliberately caught, success in the 'hunt' indicating success for the polis [...]; at the Oschophoria in Athens, a festival held in honour of Athena Skiras, there is evidence to suggest that ephebes raced from the temple of Dionysus to Phaleron, and the winner drank a fivefold cup of oil, wine, barley, cheese and flour." (ibid.). Embora essas sejam evidências tardias, elas são corroboradas pelo testemunho de Homero, que, no Canto XXIII da Ilíada, conta como Aquiles organizou um epitaphios agōn para honrar a morte de Pátroclo, descrevendo competições bastante similares àquelas dos jogos em Olímpia.
} 
vitoriosos não continham premiações para discursos, indicando que a oratória não fazia parte das competições oficiais desses jogos. ${ }^{3}$

Outra das evidências a apoiar tal juízo é o Hipias Menor, em que o personagem epônimo diz sempre ir aos jogos em Olímpia para fazer suas apresentações. ${ }^{4}$ A passagem, porém, não é suficiente para nos assegurar de que Hípias realmente se apresentava em Olímpia, já que não temos meio de verificar se tal informação tinha suporte factual ou apenas cumpria um papel dramático dentro do diálogo ao melhor caracterizar um de seus principais personagens. A comparação do diálogo com outros textos platônicos revela uma semelhança na descrição das personagens, o que nos faz duvidar do Hípias Menor como documento biográfico confiável. A pretensão de Hípias de poder falar sobre qualquer assunto que os ouvintes propusessem, por exemplo, tinha paralelo no Górgias, pois, nesse diálogo, a personagem que lhe dá título também desafiava sua audiência a lhe fazer qualquer pergunta, que ele seria capaz de responder de modo adequado (447c 7-8).

A caracterização desses personagens, de fato, dificilmente poderia ser considerada confiável, uma vez que Górgias, Protágoras e Hípias são aí apresentados como adversários de Sócrates, protagonista dos diálogos platônicos, que contesta as teses que eles propõem. De fato, ao descrevêlos como "sofistas", 5 o autor queria diferenciar esses homens, conhecidos professores em seu

\footnotetext{
${ }^{3}$ Ademais, as competições foram estabelecidas antes que a oratória fosse uma prática comum entre os gregos, de forma que seria improvável encontrar, nas panegírias, a contenda entre discursos.

${ }^{4}$ Plat. Hip. Men. 363d: : “...sempre vou à panegíria dos gregos em Olímpia, quando acontecem os jogos, de meu lar, em Élis, e no templo eu me apresento ao público, dizendo estar preparado para fazer uma demonstração sobre qualquer coisa que me queiram propor, e respondo a quem desejar o que quer que se pergunte...” (“...'О

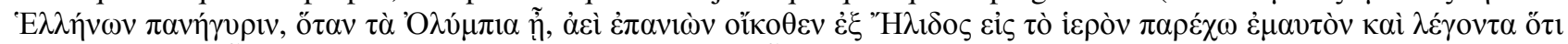

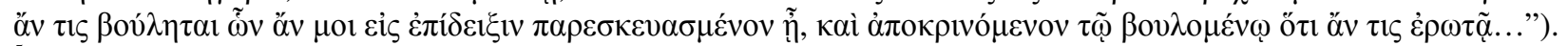

${ }^{5}$ A despeito de uma grande variedade de significados que lhe poderiam ser atribuídos, o termo "sofista" havia adquirido, no início do séc. IV a.C., um sentido mais estrito, designando certo tipo de profissional que se dedicava ao ensino. Segundo essa definição, pois, tanto Platão como Sócrates poderiam ser denominados pelos seus contemporâneos de "sofistas", uma vez que ambos preparavam, de alguma forma, os jovens atenienses para a vida adulta (é dessa forma, aliás, que Aristófanes se refere a Sócrates em sua comédia As Nuvens, na qual é um dos personagens). O fato de Platão nomear a sua disciplina de "filosofia" é também uma estratégia para diferenciar-se de pensadores pregressos cujas práticas poderiam ser identificadas às suas, além de servir para dissociar-se das críticas que eram geralmente feitas aos sofistas, já que essa designação passou a ter um sentido pejorativo no séc. V a.C., quando o termo estava relacionado a um profissional que cobrava altas somas para ensinar doutrinas extravagantes e moralmente condenáveis aos jovens (o Sócrates d'As Nuvens, por exemplo, treinava seus alunos na arte dos discursos, para que esses pudessem enganar seus credores e não lhes pagar as dívidas). Para maiores detalhes, vd. nota 3 à nossa tradução (p. 131).
} 
tempo, da "filosofia", palavra que Platão identificava com as práticas de Sócrates, ${ }^{6}$ de quem ele fora um seguidor na juventude, e do próprio ensinamento que ele desenvolvia em sua escola, em Atenas. Assim, sendo os defensores das ideias que Platão pretendia refutar, é razoável pensar que aqueles personagens fossem retratados deliberadamente de maneira desfavorável. Mais importante para o nosso estudo, contudo, é que a tipicidade do retrato de Hípias por Platão nos leva a descartar o diálogo como evidência sobre a apresentação de discursos nas panegírias.

Mas, além do Hípias Menor, dispomos de evidências adicionais, pois a antiguidade também nos legou dois fragmentos que se apresentam como parte integrante da fala de oradores a um público reunido nas panegírias. Do mais extenso entre eles, o Olímpico de Lísias, possuímos o proêmio, e, embora apenas a frase inicial do Olímpico de Górgias tenha-se conservado, o comentário que Flávio Filóstrato faz ao discurso nos informa sobre alguns aspectos do texto. Há ainda a menção, também por Filóstrato, de que Górgias pronunciou um discurso em Delfos, por ocasião dos jogos píticos, ainda que nada nos tenha restado desse texto. ${ }^{7}$

A primeira frase do discurso é tudo que temos do Olímpico de Górgias, conservada por Aristóteles na Retórica, ${ }^{8}$ além de uma breve paráfrase de uma de suas sentenças, por Clemente de Alexandria. ${ }^{9}$ Naturalmente, com evidência tão escassa, nos é impossível fazer qualquer comentário definitivo sobre o texto, ainda que possamos aí detectar alguma semelhança do trecho citado por

\footnotetext{
${ }^{6}$ Não sabemos, porém, se o próprio Sócrates classificava a si mesmo de "filósofo", e é bem provável que "filosofia" tenha adquirido uma designação específica apenas após sua morte, com Platão e Isócrates, que utilizaram o termo para designar a disciplina que eles próprios ensinavam.

${ }^{7}$ Vida dos sofistas I, 493: "Destacando-se também nas panegírias dos gregos, [Górgias] pronunciou o discurso Pítico do

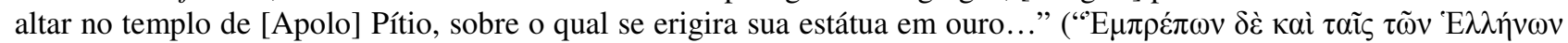

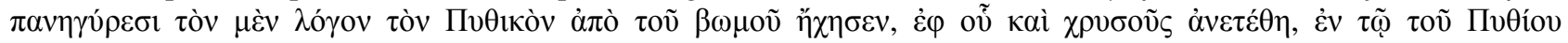

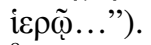

${ }^{8}$ Ret. 1414b 29: “...Górgias, no discurso Olímpico, [diz]: 'Por muitas razões são dignos de serem admirados, ó gregos',

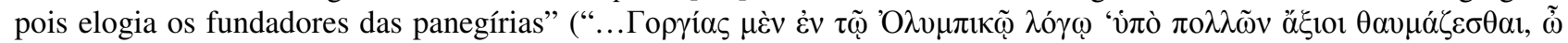

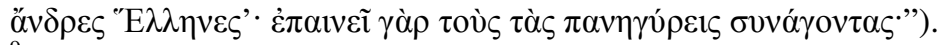

9 “...nossa 'luta', de acordo com Górgias, de Leontino, 'necessita de duas virtudes - sabedoria e coragem: da coragem, para enfrentar os perigos; da sabedoria, para descobrir o que está incógnito. Pois o logos, de acordo com o anúncio' nos

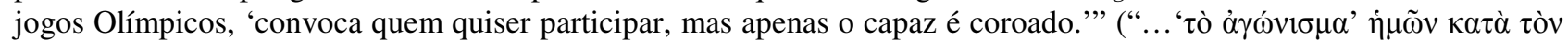

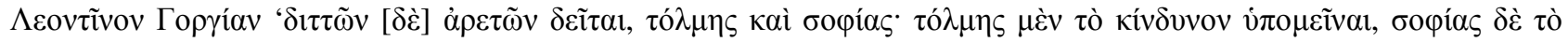

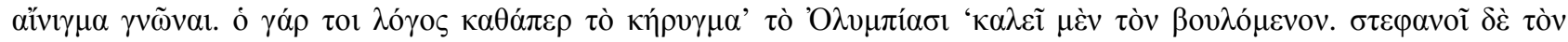

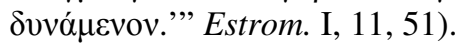


Aristóteles com a abertura do Panegírico. Nossa maior fonte de informação sobre o discurso, portanto, é o comentário de Filóstrato, que reproduzimos a seguir:

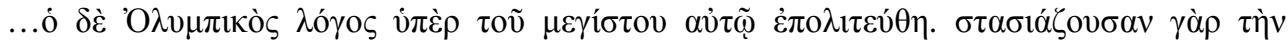

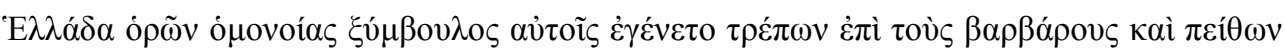

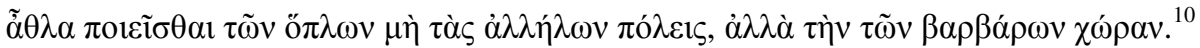

...o discurso Olímpico discute uma questão da mais alta importância política. Pois, vendo a Grécia em estado de dissensão interna, [Górgias] aconselhou a concórdia entre os gregos, exortando contra os bárbaros e persuadindo a tomar como prêmios não as poleis uns dos outros, mas a terra dos bárbaros.

O comentário de Filóstrato nos permite, portanto, estabelecer uma continuidade entre os discursos de Górgias e Isócrates, que igualmente tratam da concórdia entre os gregos, culminando em uma campanha contra os bárbaros. Também Lísias, em seu discurso Olímpico, aconselha uma proposta semelhante, ainda que este inclua, entre os alvos da campanha helênica, não somente os bárbaros, mas também um grego, o tirano Dionísio, de Siracusa. Sendo assim, não se pode negar que a composição dos discursos de Górgias, Lísias e Isócrates estivesse relacionada: o Panegírico, com efeito, faz uma indicação velada a seus predecessores, quando Isócrates diz que pretende superar o discurso de todos os sofistas que trataram das mesmas questões. ${ }^{11}$

É justificável, porém, a hipótese de que havia um gênero de discursos específicos para serem pronunciados nos festivais, tal como alguns comentadores chegaram a afirmar? A evidência que os próprios discursos nos fornecem a esse respeito está longe de ser conclusiva, e, embora haja uma evidente ligação entre os dois Olímpicos e o Panegírico, essa relação não é suficiente para supor a existência de um tipo de oratória própria às panegírias. Sendo assim, a Arte Retórica, atribuída a Dionísio do Halicarnasso (mas cuja autoria é correntemente contestada) fornece uma das únicas referências a um gênero de discursos especificamente voltado para ser pronunciado durante as

\footnotetext{
${ }^{10}$ Vida dos sofistas I, 493.

${ }^{11}$ Paneg. 4: "Não ignoro que muitos dos que professam ser sofistas se lançaram sobre este tipo de discurso, mas espero

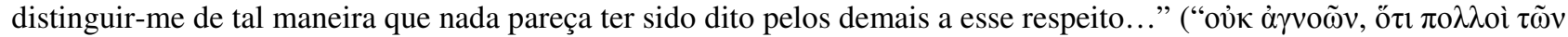

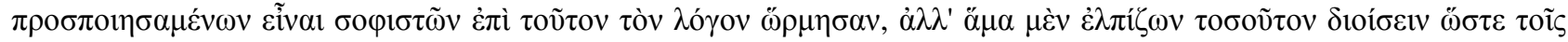

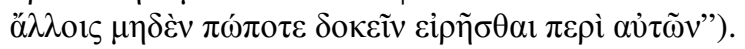


panegírias, ao tratar especificamente de um gênero panegírico. Após uma rápida apresentação das panegírias, o manual elenca os pontos obrigatórios que um orador, ao discursar em um festival, deveria abordar. George Kennedy sumariza os tópicos contidos na passagem da seguinte forma: "praise of the god associated with the festival, praise of the city in which the festival is held, praise of the contest itself and of the crown awarded, and finally, praise of the king or officials in charge". ${ }^{12}$

Essa descrição dos panegíricos, porém, contrasta com os textos de que dispomos supostamente pertencendo a esse gênero, pois, os elementos mais importantes desses textos não são os elogios à panegíria na qual eles estavam inseridos, mas as propostas de união dos gregos contra um inimigo comum. Na verdade, nos discursos de Lísias e Isócrates encontramos justamente a recusa dos tópicos elogiosos recomendados pela Arte Retórica: embora o Olímpico se inicie com uma exortação a Héracles, fundador dos Jogos Olímpicos, ${ }^{13}$ Lísias logo rejeita todo tipo de tópica de elogio - "tarefa de sofistas completamente inúteis e muito necessitados de garantir a subsistência" -, preferindo "aconselhar sobre os assuntos mais importantes, vendo a situação vergonhosa da Grécia, e que muitas de suas partes estão sob o controle do bárbaro e que muitas poleis foram destruídas por tiranos". ${ }^{14}$ O Panegírico é ainda mais enfático em negar aqueles que seriam os tópicos usuais de elogio, seus dois primeiros parágrafos contendo o contrário do que é prescrito pela Arte Retórica, isto é, não um elogio aos fundadores das panegírias, mas uma censura. $^{15}$

\footnotetext{
${ }^{12}$ Kennedy: 1963, p. 167.

${ }^{13}$ Lís. Olímp. 1: "Por variadas, numerosas e belas obras, homens da Grécia, deve-se lembrar Héracles, e em particular porque ele primeiro reuniu essa competição, em virtude de sua benevolência em relação à Grécia." ("A $\mathrm{A} \lambda \lambda \omega v \tau \varepsilon \pi \mathrm{o} \lambda \lambda \tilde{\omega} v$

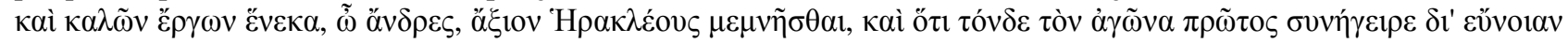

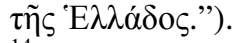

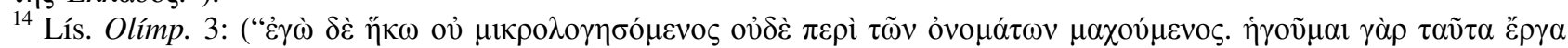

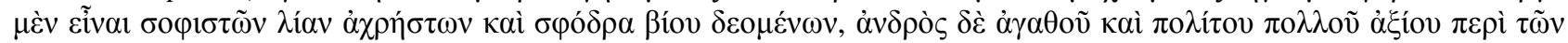

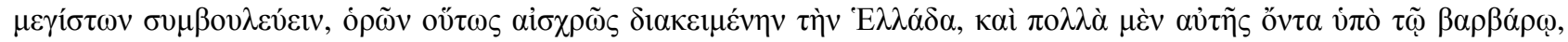

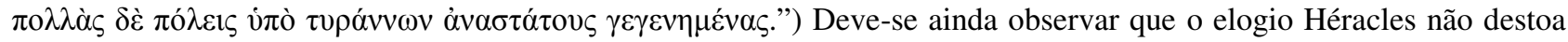
do propósito de concórdia helênica entre os gregos do Olímpico, uma vez que o herói criou os jogos Olímpicos por

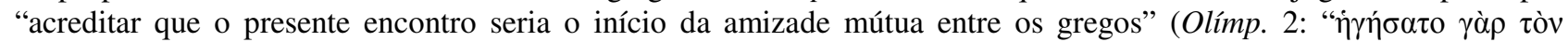

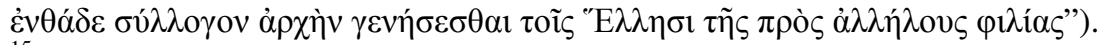

${ }^{15}$ Paneg. 1-2: "Muitas vezes me admirei que os que convocaram as panegírias e estabeleceram as competições atléticas tenham estimado os sucessos dos corpos merecedores de tão grandes privilégios, mas nenhuma honra tenham concedido
} 
Posteriormente, a qualificação "panegírico" será aplicada de forma genérica a discursos elogiosos, sem terem qualquer relação com as panegírias, a exemplo do Panegírico de Plínio, o jovem, dedicado ao imperador romano Trajano. ${ }^{16}$ É provável, porém, que esse título tenha sido adotado graças à celebridade do próprio Panegírico, que, com a perda do poder político de Atenas e a conquista macedônia sobre a Grécia no final do século IV a.C., teve sua inserção política esvaziada e passou a ser notado sobretudo como exemplo de discurso elogioso. ${ }^{17}$ Nesse sentido, a compilação retórica atribuída a Dionísio aborda o gênero panegírico, embora aí o termo ainda esteja relacionado aos festivais, enquanto no costume romano panegírico designasse tão somente o elogio de uma pessoa. É possível que o tratamento reservado ao gênero panegírico na obra, pois, tivesse uma finalidade pedagógica, expondo os tópicos de elogio próprios à ocasião para que os estudantes de retórica se exercitassem nesse tipo de discurso, mas o estado da Arte Retórica, provavelmente uma compilação de vários escritos oriundos de épocas diferentes, não nos permite fazer afirmações conclusivas a seu respeito. ${ }^{18}$

aos que se esforçaram duramente em sua vida privada em favor do bem público e que prepararam as próprias almas de tal forma que também aos demais pudessem ser úteis - é desses que seria razoável terem tido maior preocupação. Com efeito, mesmo se os atletas dobrassem a sua força, não haveria nenhuma vantagem para os demais; no entanto, se um só

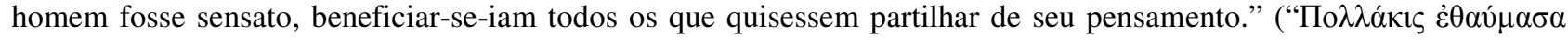

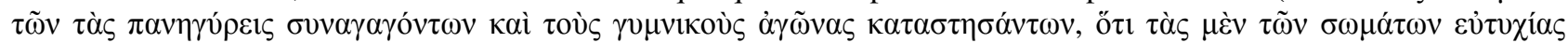

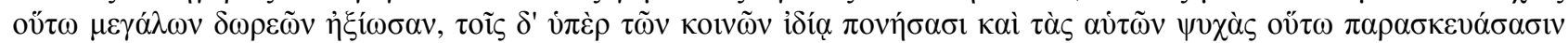

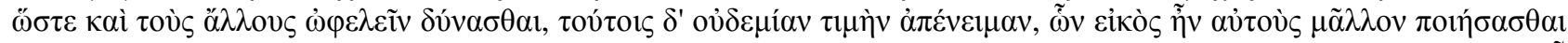

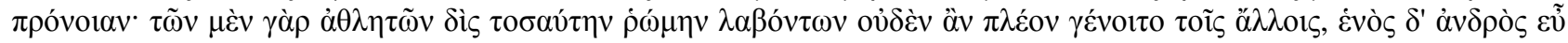

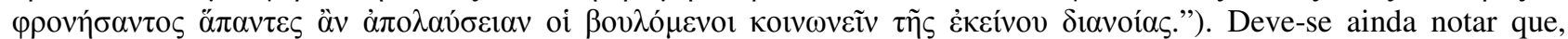
nesses dois primeiros parágrafos, Isócrates se utiliza da estratégia continuada de inverter as expectativas dos leitores, não somente por censurar quando outros elogiam, mas também usando o verbo thaumazō em um sentido diferente de seu predecessor, Górgias (vd. p. 56-57 deste estudo introdutório).

${ }^{16}$ Para maiores detalhes sobre os panegíricos romanos, vd. Rees: 2007, p. 136-48.

17 “...the specific name of panegyrikos logos is not recorded prior to the fourth century B.C.E. Gorgias' speech at the Olympic festival in 408 is referred to by Aristotle as an Olympikos logos (Rhet. 1414b 31) and Lysias' speech in 388 is traditionally titled Olympiakos [...], even though later commentators refer to both speeches as panegyrics. According to Liddell and Scott $(1940,1297)$ and data gathered from the Thesaurus Linguae Graecae database [...], Isocrates may have been the first to give a specific name to speeches given at such gatherings by naming his famous appeal for Hellenicity Panēgyrikos in 380 B.C.E. This was Isocrates' most famous composition and may well have popularized the use of the term to describe a particular type of speech." (Schiappa: 1999, p. 190).

18 "The Art of Rhetoric, attributed to Dionysius of Halicarnassus, is not by Dionysius and is not an art of rhetoric. It is a disparate assemblage of essays on a variety of rhetorical themes rather than a systematic treatise, and it contains the work of more than one rhetorician. These essays once circulated without any indication of their authorship. A scholion on chapter 10 infers from a cross-reference to a work On Imitation (364.24, cf. 373.22) that the author was Dionysius of Halicarnassus, and this conjecture was subsequently extended to cover the whole collection..." (Heath: 2003, p. 81). 
Restando claro que não havia, ao menos na época de Isócrates, um tipo de oratória característico das panegírias, resta questionar a suposição de que esses eventos acolhessem de forma regular a apresentação de oradores. Esse é um equívoco originado com os gramáticos e filólogos da antiguidade, que, ao nos oferecerem grande parte das informações de que dispomos sobre os discursos Olímpicos, situam sua apresentação nos Jogos Olímpicos. Os comentadores modernos aceitaram como verídicas tais informações, e sua única contribuição no debate acerca desses discursos foi tentar estabelecer a datação dos textos. Dessa forma, convencionou-se que Górgias pronunciou seu discurso em 392 a.C., tendo como base a datação do discurso de Lísias, 388 a.C., ${ }^{19}$ segundo Diodoro da Sicília (XIV, 109), que, em seu relato sobre os Jogos Olímpicos desse ano, retrata o autor apresentando o discurso à multidão. Tais discussões, porém, tornam-se menos relevantes para o entendimento desses textos, se considerarmos tratar-se de peças escritas, as quais, mesmo que supostamente reproduzissem uma fala anteriormente realizada em um espaço público, sofriam um processo de revisão, de forma que a serem adaptados a um modo diferente de transmissão. $^{20}$

Anteriormente, em nosso exame sobre a composição do Panegírico, apontamos para os graves erros de interpretação resultantes da tentativa de situar textos escritos antigos em um momento preciso no tempo. Cabe questionar, portanto, a validade dos testemunhos antigos sobre o suposto momento de apresentação dos discursos e, consequentemente, das datações que os filólogos modernos obtiveram a partir delas. Pode-se fazer a objeção de que autores como Flávio Filóstrato e Diodoro da Sicília, por terem escrito sobre esses discursos alguns séculos depois de sua composição, não são fontes confiáveis de informação. Pois é provável que os autores acima mencionados, sem dispor de qualquer dado relativo à apresentação do discurso, usassem informações presentes nos próprios textos para determinar as circunstâncias de sua apresentação. Essa hipótese resulta, portanto, de uma leitura apressada dos textos em questão, ignorando a

\footnotetext{
${ }^{19}$ Blass: 1887 , p. 59.

${ }^{20} \mathrm{Vd}$. nossas considerações a esse respeito na seção "composição" do primeiro capítulo de nosso estudo (p. 8-21).
} 
possibilidade de que Górgias e Lísias, ao mencionarem os Jogos Olímpicos, talvez não estivessem fazendo referência a uma apresentação nesse festival, depois preservada pela escrita, mas que os Olímpicos mimetizavam uma fala pronunciada durante essa ocasião.

O expediente de compor discursos fictícios, com efeito, não seria estranho aos autores, como provam os Epitáfios presentes nas obras de Górgias e Lísias. Epitáfios eram os discursos pronunciados em Atenas no sepultamento dos cidadãos mortos na guerra. Tratava-se de um evento especial, no qual a escolha do orador era feita pelo conselho da polis, e é provável que apenas cidadãos atenienses fossem admitidos a falar nessa ocasião, vedando-se a participação de estrangeiros como Górgias e Lísias, ambos de origem siciliana. ${ }^{21}$

Embora não possamos afirmar com a mesma segurança que Górgias e Lísias não tivessem declamado os Olímpicos durante os jogos, a análise dos testemunhos sobre sua apresentação deixa dúvidas quanto a essa possibilidade. Isso é mais claro no caso de Lísias, do qual possuímos não somente alguns parágrafos do discurso, mas também dois relatos sobre sua apresentação feitos por autores diferentes.

Como dissemos anteriormente, o texto supérstite do Olímpico nos foi conservado por Dionísio do Halicarnasso, em seu tratado Lísias. No breve comentário que precede a citação, o gramático sumariza a proposta principal do discurso, dizendo que Lísias o compôs como um ataque a Dionísio de Siracusa, tentando persuadir os gregos, reunidos em Olímpia para assistir aos jogos, a derrubar a luxuosa tenda que o tirano mandara construir para sua comitiva. ${ }^{22}$ Não é surpresa que Lísias tenha dedicado um de seus textos a acusar Dionísio, uma vez que a família do autor,

\footnotetext{
${ }^{21}$ Sobre a cerimônia de enterro dos heróis de guerra atenienses e o discurso que a acompanhava, vd. n. 32 a nossa tradução (p. 140).

${ }^{22}$ Dion. Halic. Lís. 29: "Há um discurso panegírico de sua [Lísias] autoria, no qual ele tenta persuadir os gregos, quando se realiza a panegíria em Olímpia, a retirar do poder o tirano Dionísio, a libertar a Sicília e a começar a irar-se imediatamente, despedaçando a tenda do tirano, ornada com ouro, púrpura e muitas outras riquezas. Pois Dionísio enviara emissários às panegírias trazendo um sacrifício ao deus, e preparou-se naquele lugar um magnífico e rico

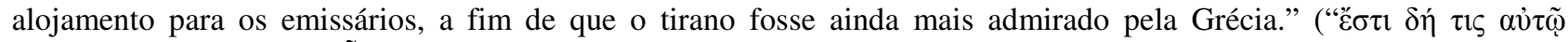

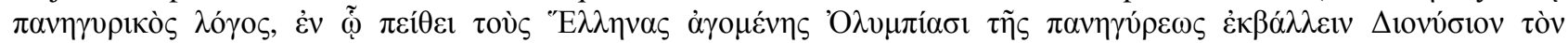

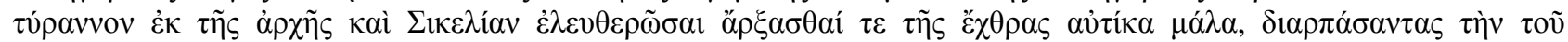

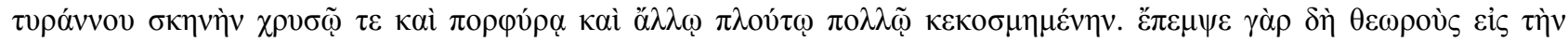

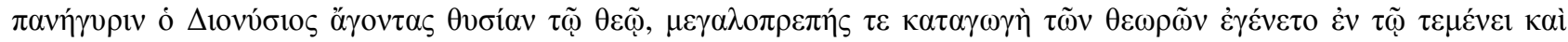

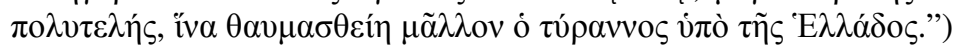


originária de Siracusa, fora obrigada a fugir de sua polis natal quando o tirano tomara o poder; não temos provas, porém, para supor que o autor tivesse apresentado esse discurso pessoalmente em uma das panegírias, como afirmara Diodoro e os comentadores modernos. ${ }^{23}$

É possível supor que um trecho hoje perdido do Olímpico contivesse a exortação para que os visitantes da panegíria colocassem abaixo a tenda da comitiva siracusana, uma vez que Dionísio do Halicarnasso, o qual provavelmente conhecia o texto em sua integralidade, refere-se a ela no comentário preliminar à citação do discurso. Ainda assim, não se pode considerar que tais expedientes fossem exclusivos de uma declamação e, portanto, prova de que Lísias tivesse apresentado o discurso em Olímpia antes de sua publicação, uma vez que a imitação da fala operada por textos escritos incluía endereços fictícios a uma audiência inexistente. A Antídose de Isócrates, por exemplo, utilizava-se amplamente desse recurso, quando o autor pedia a um inexistente oficial da corte que lesse a acusação (29) ou quando o autor reclamava do seu tempo para discursar, limitado pela clepsidra (320), mesmo que, logo no início do discurso, Isócrates tivesse afirmado que a Antídose visava exclusivamente à leitura. ${ }^{24}$

As evidências a esse respeito, ao menos, não são conclusivas. O testemunho de Dionísio do Halicarnasso, por exemplo, embora seja usado como fundamento para tal juízo, parece apontar para a direção contrária. Pois o gramático refere-se à suposta apresentação de Lísias em Olímpia não como dado biográfico, mas como hypothesis, isto é, como a premissa a partir do qual o orador poderia construir seu discurso. ${ }^{25}$ De forma que a associação do discurso aos Jogos Olímpicos não era indicativa de uma possível apresentação do discurso pelo orador, mas tratava-se de um topos, já utilizado por Górgias e do qual Lísias se reapropriou para lançar seu ataque contra um inimigo político. É Diodoro da Sicília que, a partir de uma leitura ingênua do Olímpico, considera que o

\footnotetext{
${ }^{23}$ Todos os comentadores consultados na realização deste trabalho, ao menos, não expressam qualquer dúvida quanto à apresentação do Olímpico ao público (Blass: 1887, p. 430-32; Gernet; Byzos: 2003, p. 201; Todd: 2000, p. 332); o único ponto de controvérsia entre esses estudiosos é a questão da data em que essa apresentação teria acontecido, se em 388 ou em 384 a.C.

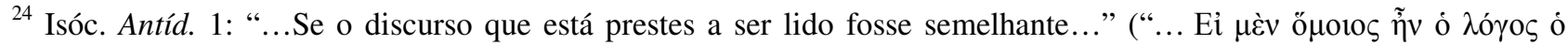

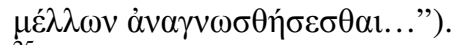

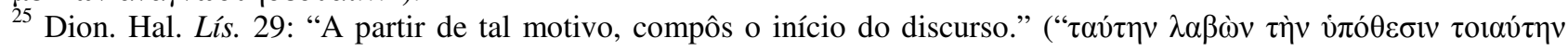

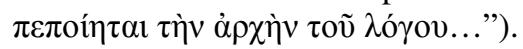


autor pronunciou o discurso durante os Jogos Olímpicos de 388 a.C. ${ }^{26}$ Dificilmente, porém, poderse-ia acreditar no relato do historiador, que retrata Lísias, com o texto casualmente em mãos quando os gregos decidem atacar a tenda de Dionísio, ${ }^{27}$ a ler seu discurso para a multidão enfurecida. ${ }^{28}$

Não está totalmente claro o motivo que levou os autores a recriar, em seus discursos, uma ocasião ficcional de apresentação, quando esses visavam tão somente à leitura, não à declamação. A partir dos próprios textos, porém, somados a informações de que dispomos sobre a prática de seus autores, podemos aventar algumas possibilidades de leitura para tais obras. Em primeiro lugar, pode-se interpretar a relação que esses discursos mantêm com as panegírias a partir da poesia. A apresentação de poetas e músicos, ${ }^{29}$ com efeito, era uma parte importante dos festivais na Grécia antiga. Os Jogos Píticos e Nemeus premiavam, além dos atletas, poetas e músicos, ${ }^{30}$ e parte considerável da poesia mélica anterior a Alexandre fora composta tendo em vista primeiramente a apresentação em festivais. ${ }^{31}$ Ademais, a poesia dramática grega também era pronunciada em festivais, na Ática, sendo ela um desenvolvimento da poesia coral apresentada nas versões mais antigas desses eventos. ${ }^{32}$ Os discursos de Górgias, Lísias e Isócrates, pois, ao vincularem-se a tais

\footnotetext{
${ }^{26}$ Diod. Sic. Bibl. XIV, 109: “Com efeito, Lísias, o orador, que então estava em Olímpia, exortava a multidão a não aceitar nos jogos sagrados os emissários egressos da mais ímpia tirania. Foi naquele momento em que ele leu seu

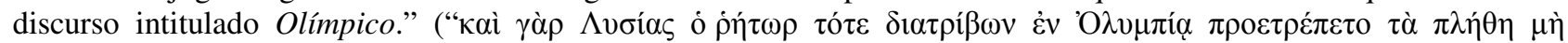

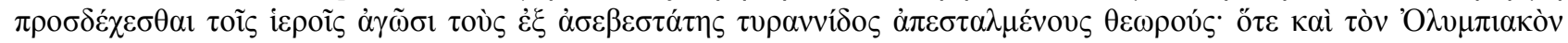

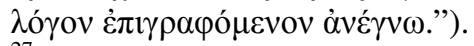

${ }^{27}$ Segundo nos conta o historiador, Dionísio havia, em um primeiro momento, despertado a admiração dos gregos pela suntuosidade da tenda que abrigava a comitiva siciliana, dos carros que iriam competir e também por ter trazido os melhores rapsodos. O tirano, no entanto, causou a ira da multidão ao ordenar que se lhe recitassem os poemas que havia composto, todos de péssima qualidade, segundo Diodoro. O saldo dessa aventura foi negativo para Dionísio, pois, além do ataque à tenda e da rejeição de seus poemas, ele perdeu os carros que enviara, destruídos durante a corrida, e o barco que retornaria sua comitiva afundou antes de chegar à Sicília (Bibliot. XIV, 109).

${ }^{28}$ Dessa forma, o relato de Diodoro contrasta com Alcidamante, dizendo que seria ridículo um orador se apresentar diante do público com um livro em mãos (Dos escritores de Discursos Escritos, 11).

${ }^{29}$ A separação da poesia e da música é um evento tardio no mundo grego, e muito da poesia grega antiga de que hoje dispomos, se não foi composta para ser cantada, era recitada com o acompanhamento de um instrumento musical (como no caso dos poemas homéricos, já que, em suas apresentações, os rapsodos também tocavam a forminge).

${ }^{30}$ Os Jogos Píticos tinham como fundador mítico Apolo, um deus que, além de outras atribuições, tinha uma relação muito próxima com a poesia. As Píticas 10 e 12 de Píndaro, por exemplo, são dedicadas aos vencedores dos concursos da flauta dupla e da flauta.

${ }^{31}$ Os exemplos mais impressionantes desses poemas são os dois Partênios do poeta espartano Álcman, compostos para serem cantados por um coro de virgens, talvez em uma das edições das Carneias, festival regional da Lacedemônia. Parte da dificuldade na compreensão desses poemas, com efeito, está relacionada às referências feitas à ocasião de performance. Ewen Bowie (1986, p. 27-34), ademais, estabeleceu que elegias longas, como os Esmirneus, de Mimnermo, foram compostas para participar das competições nos festivais.

${ }^{32}$ Dessa forma, as tragédias e comédias conservavam, como um resquício da antiga poesia coral da qual provavelmente advinham, o coro. Este cantava odes em um dialeto que se aproximava do dórico (embora contivesse elementos áticos),
} 
ocasiões por meio da escrita, pretendem-se como substitutos da poesia, sem, no entanto, estar limitada a uma ocasião específica como com a poesia.

Outra possível interpretação desses discursos é a de que eles fossem utilizados no aprendizado da oratória, ${ }^{33}$ ao fornecer modelos os quais os estudantes pudessem copiar no aprendizado da composição de discursos. Essa hipótese é particularmente adequada ao caso de Górgias, que sabemos ter atuado como professor e que provavelmente a composição de discursos entre seus ensinamentos. É verdade que o texto restante de seu Olímpico é demasiado escasso para se fazer qualquer afirmação conclusiva; ainda assim, se pudermos fazer uma aproximação com outros textos disponíveis desse autor, vemos que o uso pedagógico de discursos escritos era uma prática comum de Górgias.

O Epitáfio, em particular, exemplifica com perfeição essa tese, ao menos pelo pouco que o restante do discurso nos deixa perceber. Thomas Cole, com efeito, ao se deparar com a rígida sintaxe de sentenças antitéticas encadeadas umas após as outras característica do fragmento supérstite, ${ }^{34}$ argumentou que se tratava de uma technē, isto é, de um texto composto quase que somente por argumentos genéricos, que pudessem ser facilmente adaptados por um estudante de oratória na composição de seus próprios discursos ou por um leigo, quando fosse obrigado a se pronunciar em um evento público. ${ }^{35}$

reforçando a hipótese de que a poesia dramática ateniense tivesse origem nos cantos corais, tradicionalmente compostos em dórico. Como exemplo, podemos citar Píndaro, que, embora fosse natural de Tebas, onde se falava um dialeto da família lésbio-eólica, compusera suas odes corais em dórico.

33 "Retórica", no início do IV século a.C., ainda não designava uma disciplina estabelecida, o rhētōr, palavra da qual deriva, designando apenas o orador. Sendo assim, apenas com o diálogo Górgias, de Platão, que essa palavra aparecerá associada também ao professor de oratória, o qual é capaz de tornar seus alunos rhètores por meio de uma disciplina que lhe é própria, a retórica. Para maiores detalhes, vd. Schiappa: 1990.

${ }^{34} \mathrm{O}$ estudioso descreve as características do discurso de Górgias, considerado por ele o limite extremo do que era normalmente produzido na prosa ática no início do século IV a.C.: “...formality, harshness, syntactical regularity, grammatical precision, compactness, neglect of èthos, abstractness, and generality. [...] Attic prose of this period is a prose of abstractness and ideas: its aim is to free syntax of extravagance and irregularity; its couched in the general, abstract terms needed for its sweeping reorganization of inherited views, inclined to regard intrusions of the colloquial with suspicion." (Cole: 1991, p. 73-74).

35 "The public that Attic writers had in mind [...]: a public of speakers, or prospective speakers [...]. And the typical Attic text gives the impression of having been composed for 'practice and demonstration'. It is a model piece devoted to the sort of subject likely to come up for repeated discussion in political, judicial, or epideictic oratory and designed to be useful in as wide a variety of situations as possible." (Cole: 1991, p. 75). Sobre as technai, vd. ainda nossa discussão preliminar nas p. 18 et seq. 
Em sua análise do Epitáfio de Górgias, Cole distingue esse texto como o exemplo extremo da prosa ática do período, voltada para o aprendizado da oratória, e que teria como contrapartes as Tetralogias, de Antifonte, ou os Dissoi Logoi, de autor desconhecido. Esses textos apresentavam uma mesma situação de duas perspectivas diferentes (ou, no caso das Tetralogias, de quatro perspectivas diferentes), revelando seu caráter pedagógico, ao possibilitar que seu leitor dispusesse de argumentos nas duas situações possíveis de um discurso, ao defender ou atacar uma proposta. Isócrates também pretendia que seus discursos fossem modelos para os alunos de sua escola, como fica claro sua descrição das tarefas do professor no Contra os Sofistas que ele deve fazer de si mesmo um exemplo para seus alunos, ${ }^{36}$ uma afirmação que incidia diretamente sobre a prática discursiva, mas não se limitava a ela, devendo também ser um modelo de conduta moral para os alunos.

Ao contrário dos sofistas aí criticados, porém, o autor faz de seus discursos não apenas modelos oratórios, mas também exemplos políticos e éticos, a partir dos quais os alunos poderiam modelar sua conduta e tornar-se melhores cidadãos. Uma primeira diferença que detectamos, pois, entre os discursos de Isócrates e as technai anteriormente citadas seria o uso de uma elocução mais desenvolvida, abundante no uso de períodos e longas sentenças. ${ }^{37}$ Mas, de especial interesse para nós em tais escritos, seria a seleção de um assunto que tivesse importância para toda a Grécia, e não apenas de proveito particular, uma vez que as technai estariam demasiado vinculadas ao aspecto judicial da oratória, reproduzindo, com sua estrutura de argumento/contra-argumento, a duplicidade de funções própria aos tribunais, em que o orador deveria assumir necessariamente o papel de defensor ou acusador.

\footnotetext{
${ }^{36}$ Cont. Sof. 17-18: “...o professor [deve] ser capaz de fornecer em si mesmo tamanho exemplo, de forma que os assim formados e capazes de imitar parecerão falar de forma mais elegante e graciosa que os demais" “...

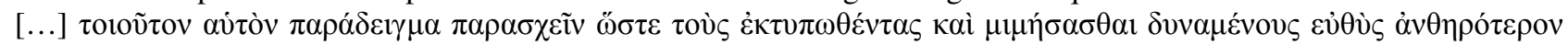

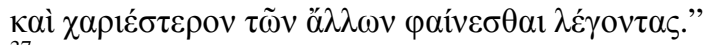

${ }^{37}$ Stephen Usher, em estudo estatístico sobre a obra do autor, conclui que, de todos os discursos de Isócrates, o Panegírico é aquele que contém o maior número das figuras de linguagem características do autor: "That Isocrates intended the Panegyricus to mark the high point of his mature epideictic style is reflected strikingly in the figures [...] Interpreted in terms of periodic structure, these figures imply great length and complexity, with an average of $41 / 2$ periods per page, but no excess of concatenated structure or tendency for periods to sag in the middle after the manner of the second example." (1973, p. 51).
} 
Como vimos no capítulo primeiro deste estudo, porém, Isócrates pretende claramente dissociar seus escritos dos modelos retóricos compostos por outros autores, dando-lhes um valor não somente de modelo para a prática oratória, mas principalmente como um exemplo para a conduta política. Nesse sentido, a proposta inicial do Panegírico já seria uma primeira e importante para distinguir o discurso daqueles textos voltados, até onde sabemos, apenas à oratória judicial.

Para concluir nosso estudo sobre o Panegírico, porém, gostaríamos de retornar à questão inicial deste capítulo - a de gênero, investigando qual a exata relação entre os textos de Górgias, Lísias e Isócrates. Como vimos acima, embora haja textos com os quais o discurso mantém uma relação muito próxima, as semelhanças de todos esses discursos não justificam os colocarmos sob uma categoria tão rígida de gênero retórico, e, ainda que não se possa afirmar que os discursos tardiamente entitulados de "panegíricos" constituíssem um gênero específico, os autores estabelecem uma relação com os predecessores que não se limitava apenas a retomar as mesmas questões antes propostas, mas em que a imitação de um modelo prévio pressupunha também sua emulação e superação.

O único trecho que temos comum aos três discursos é o proêmio; do Olímpico de Górgias, por exemplo, temos apenas duas citações por Aristóteles e Clemente de Alexandria. Ainda assim, a evidência existente nos permite estabelecer entre o início do discurso, uma vez que uma das partes supérstites do Olímpico de Górgias é a frase inicial, enquanto o Olímpico de Lísias conserva seu proêmio. Todos os três discursos se iniciam com a menção aos fundadores das panegírias, mas enquanto os Olímpicos fazem um elogio a esses homens, Isócrates prefere fazer o contrário de seus predecessores e censurar os fundadores das panegírias. Com efeito, Aristóteles notara que, em sua citação de Górgias, que o dito de abertura do discurso era o contrário do que dizia o Panegírico: "Isócrates, ao contrário, censura [os fundadores das panegírias], por terem honrado as virtudes dos corpos com dons, não tendo dedicado nenhum prêmio aos que são sensatos." ${ }^{38}$ Outra divergência

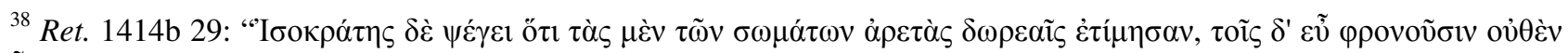

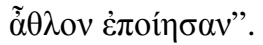


notável aparece no emprego do verbo "thaumazō". Presente em ambos os textos, Górgias o utiliza com o sentido de "admirar", enquanto no Panegírico ele adquire um sentido diferente - "admirarse", "espantar-se". 39

Os exemplos encontrados nesses dois textos tornam evidente a relação que Isócrates estabelecia entre seus próprios discursos e aqueles de seus predecessores, nos quais ele encontrava elementos usados na composição de seus próprios textos. Com efeito, tanto a proposta central da campanha contra a Pérsia quanto a ideia de associar esse apelo com uma panegíria não são ideias originais do autor, mas haviam sido usadas pelos seus predecessores; mas, ao retomar essas questões em termos semelhantes a Górgias e a Lísias, o autor se apropriava de elementos utilizados por outros autores, mas ao fazê-lo, invertia seu significado original, uma forma de se destacar de seus predecessores, revelando, nesse procedimento, o caráter antagonístico da oratória nos séculos V e IV a.C., quando os professores de oratória, para se provarem dignos de seus alunos, deveriam mostrar que eram superiores aos demais. Dessa forma, Isócrates, no Panegírico, reconhece que, antes dele, outros haviam se lançado sobre o mesmo tema; ainda assim, o autor pretende alcançar tamanha distinção, que fizesse esquecer todos os outros que antes também haviam proposto, tomando como cenário uma panegíria, uma campanha helênica contra os inimigos da Grécia. ${ }^{40}$ Que dos discursos de Górgias e Lísias restem apenas uns poucos fragmentos, enquanto o Panegírico sobreviveu até os nossos dias em sua integralidade, pode ser considerado uma irônica confirmação das pretensões que Isócrates expressa nesse discurso.

\footnotetext{
${ }^{39}$ Buchner: 1958, p. 16.

${ }^{40}$ Paneg. 3-4: "Não ignoro que muitos dos que professam ser sofistas se lançaram sobre este tipo de discurso, mas

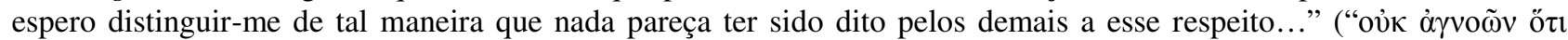

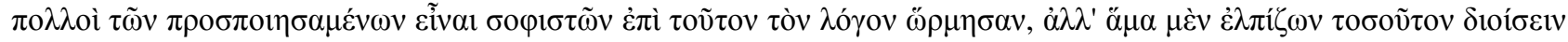

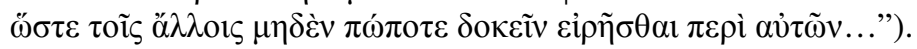




\section{PREFÁCIO À TRADUÇÃO}

A tradução do Panegírico apresentada a seguir é a primeira feita em língua portuguesa ${ }^{1}$ e guarda, portanto, a grande responsabilidade de introduzir ao público lusófono essa obra, um dos mais importantes discursos do autor. A principal finalidade de nossa tradução, pois, é a de fornecer ao leitor de língua portuguesa um texto confiável, no qual ele possa apreender as principais questões tratadas pelo Panegírico, de forma que, ao verter o texto para o português, nossa principal preocupação foi a de mantermo-nos o máximo possível próximos das palavras de Isócrates. As longas sentenças de Isócrates, porém, mostraram-se um desafio à tradução, de forma que, para não perder a legibilidade e a clareza próprias do texto grego, por vezes fomos obrigados a sacrificar a sintaxe característica do autor.

As notas têm o objetivo de providenciar um comentário ao discurso, que, se não é exaustivo, ao menos tenta expandir as referências de Isócrates, comparando-lhes com escritos de outras fontes ou do próprio autor, dando assim uma visão mais ampla sobre as passagens comentadas. Tendo esse intuito, pois, não tememos ser, por vezes, demasiado extensos, o que não acreditamos ser motivo de censura em um trabalho acadêmico.

O texto utilizado na tradução foi o de Mandilaras, resultado da edição mais recente da obra do autor e publicado em 2003 pela Bibliotheca Teubneriana, coleção geralmente utilizada pela crítica especializada como base de seus comentários para autores antigos. As poucas discordâncias que tivemos com o editor, anotadas abaixo, resultaram da comparação com o aparato crítico ou do cotejo com o texto editado por Georges Mathieu para a coleção Belles Lettres.

\footnotetext{
${ }^{1}$ Ao menos até onde pudemos verificar, não existem outras versões do texto em português. Os lusófonos, com efeito, são carentes de versões dos textos isocráticos (um problema que, infelizmente, não se limita a esse autor, faltando-nos traduções de obras fundamentais da antiguidade), e as únicas traduções de Isócrates que pude encontrar são aquelas feitas por Maria Helena Ureña Prieto (A Nícocles, Areopagítico e Sobre a paz; vd. Prieto: 1989), Júlio Lopes Rego (A Demônico, A Nícocles, Nícocles e Evágoras; vd. Rego: 2011) e Ticiano Curvelo Estrela de Lacerda (Contra os Sofistas e Elogio de Helena; vd. Lacerda: 2011), estes dois últimos, meus colegas no Programa de Pós-Graduação em Letras Clássicas.
} 


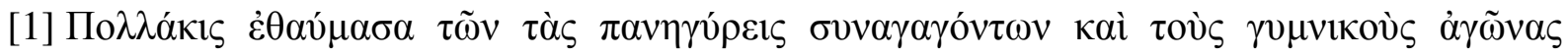

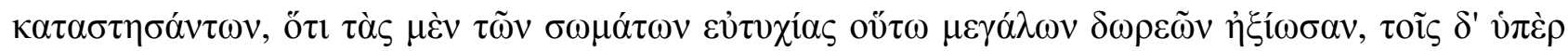

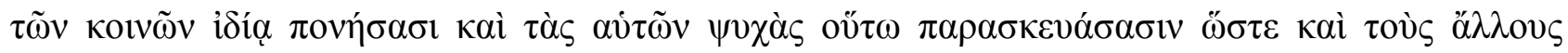

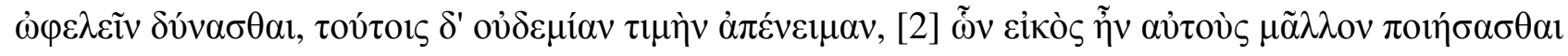

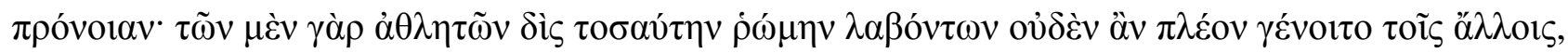

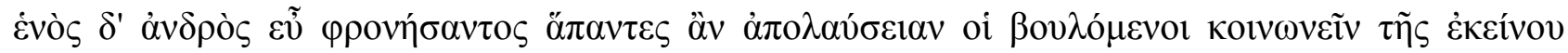

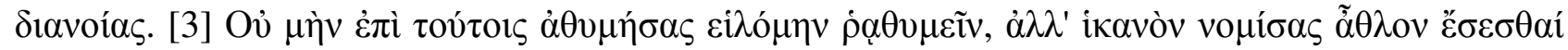

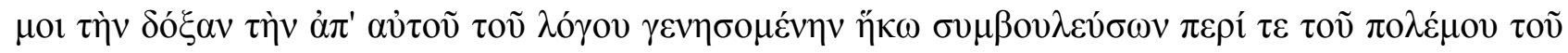

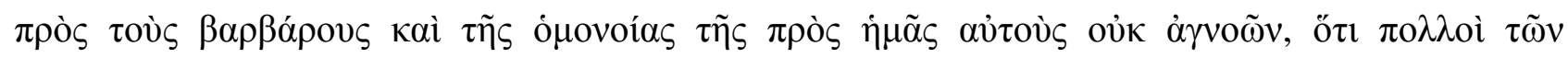

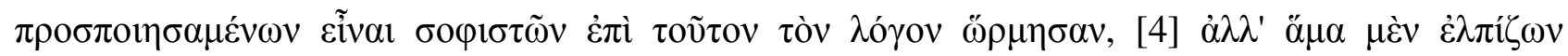

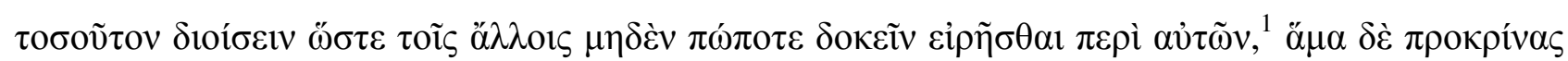

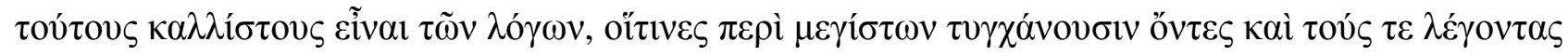

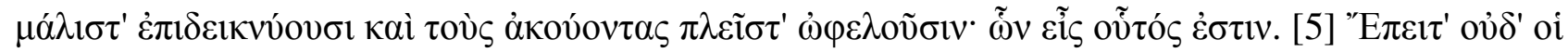

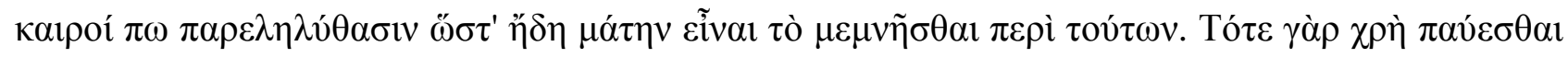

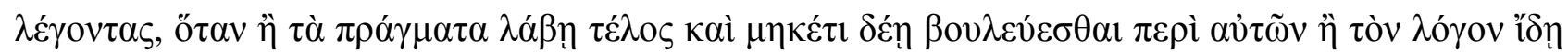

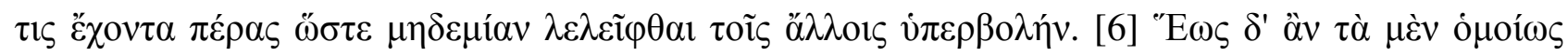

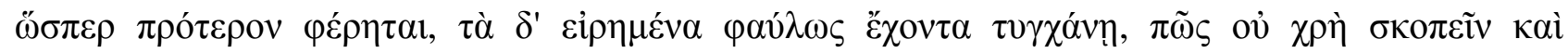

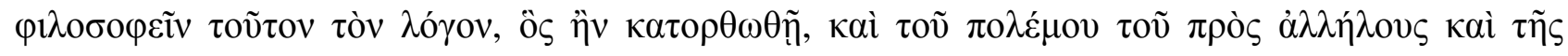

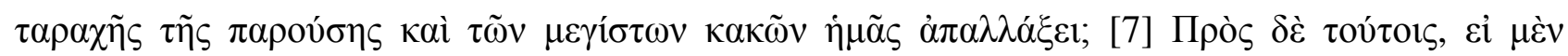

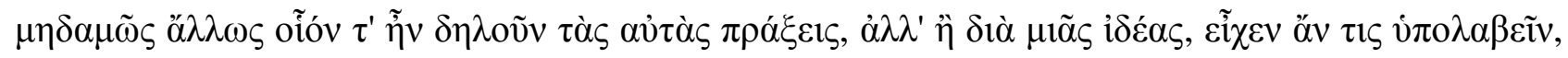

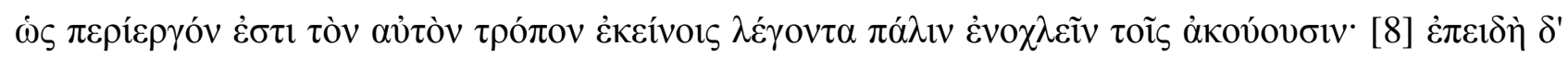

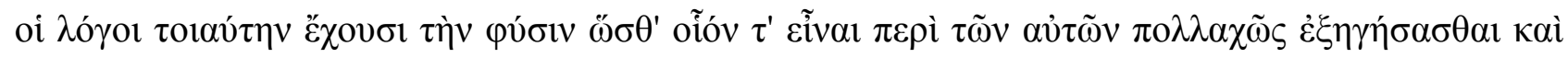

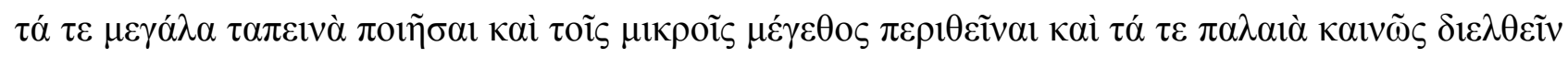

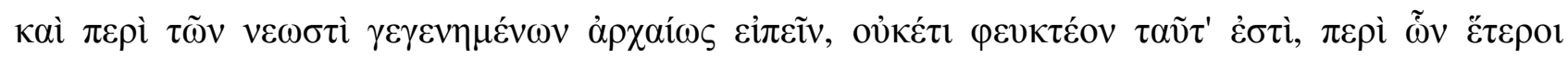

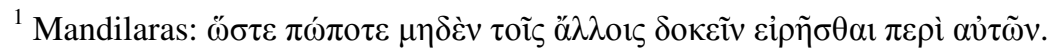




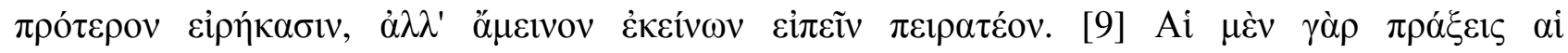

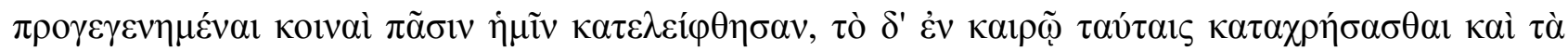

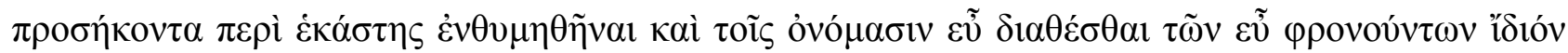

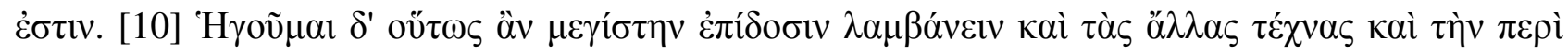

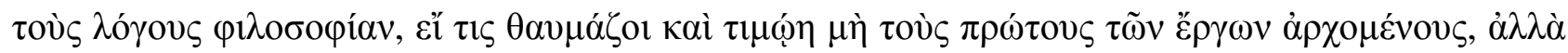

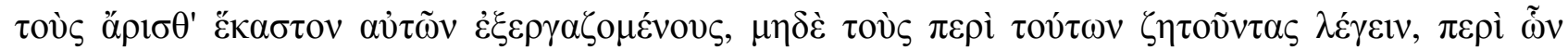

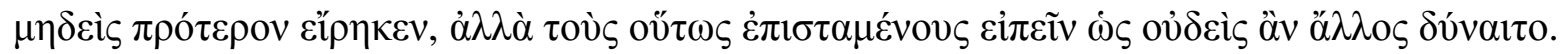

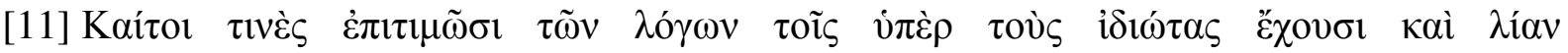

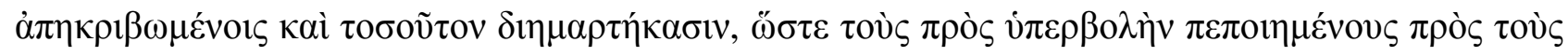

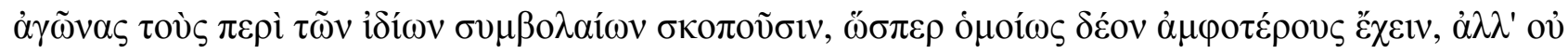

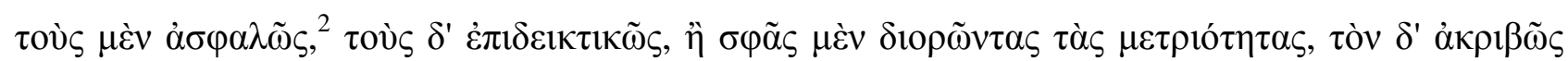

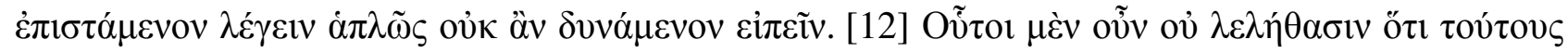

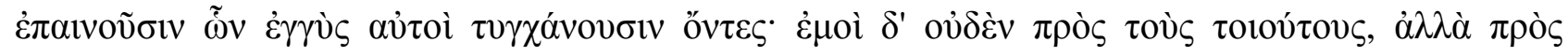

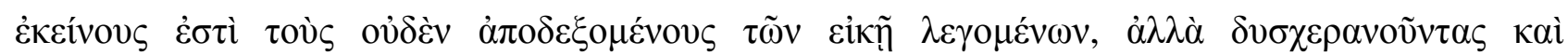

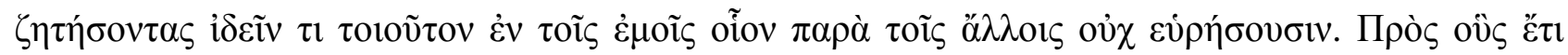

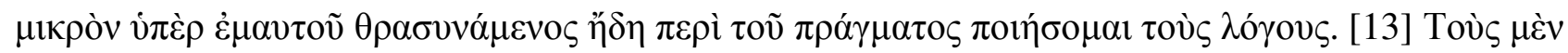

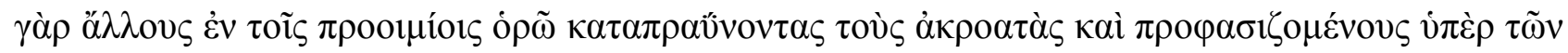

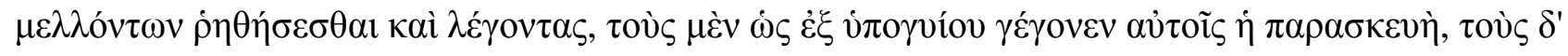

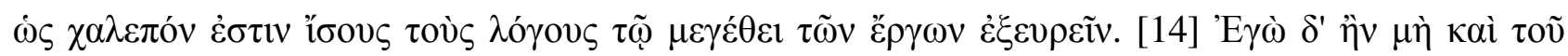

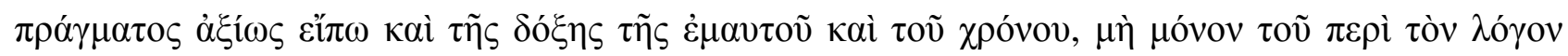

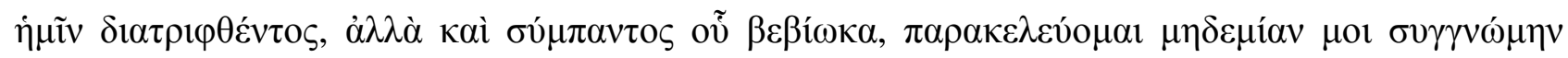

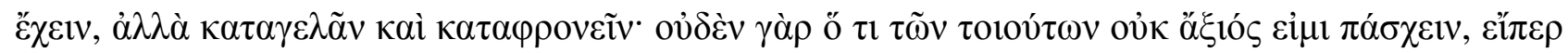

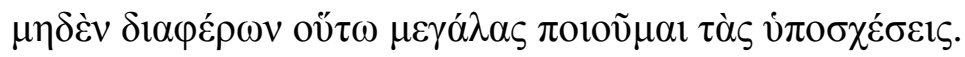

\footnotetext{
${ }^{2}$ Conjectura de Valckenaer para $\dot{\alpha} \sigma \varphi \alpha \lambda \tilde{\omega} \varsigma$, encontrado nos manuscritos.
} 


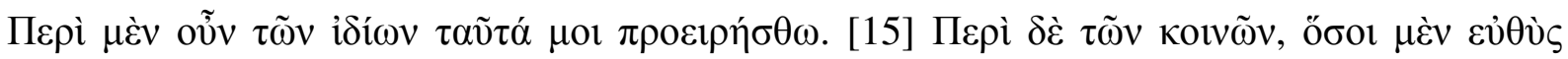

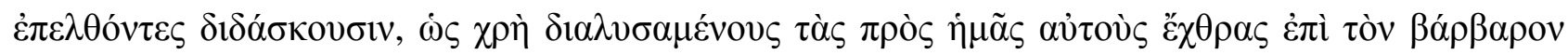

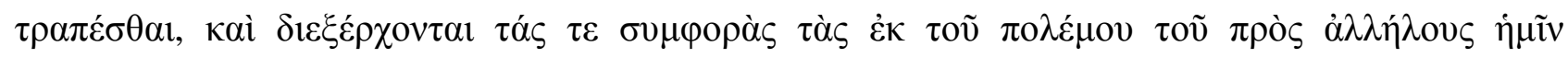

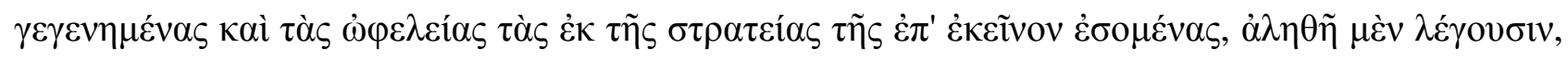

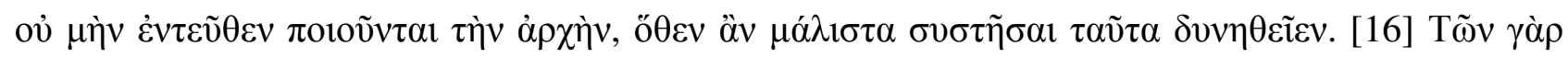

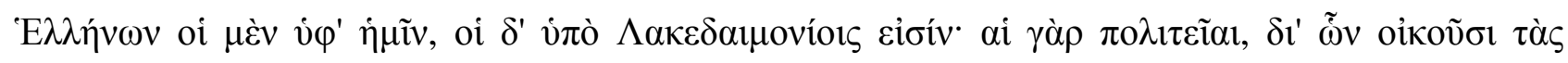

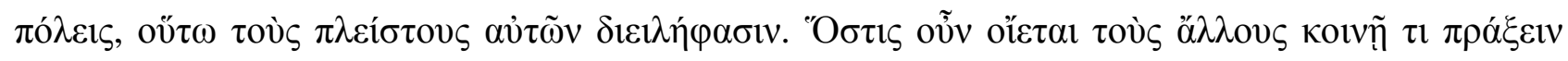

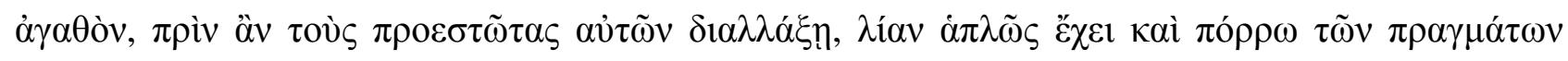

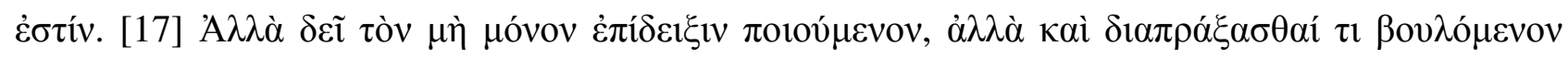

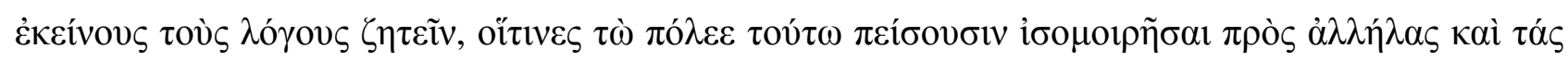

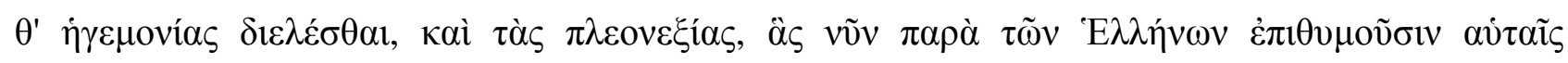

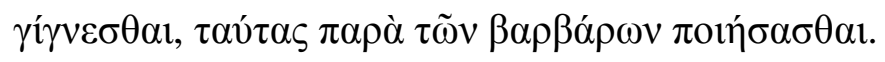

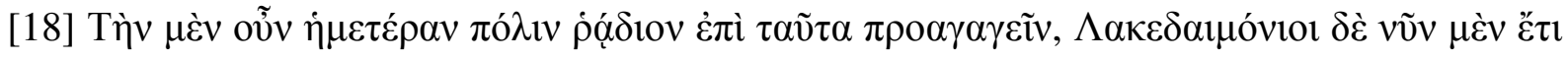

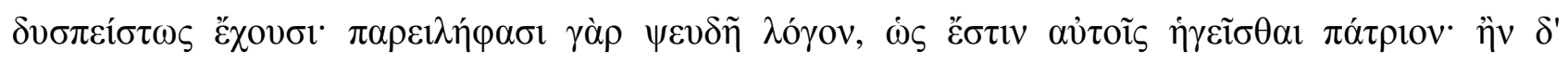

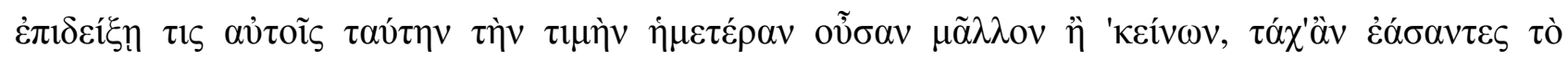

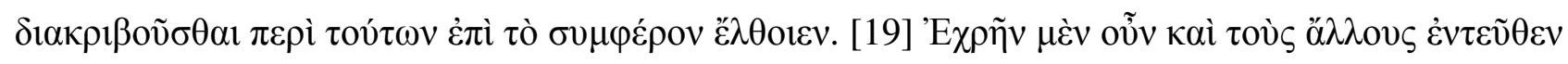

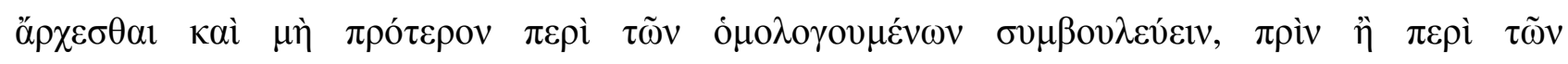

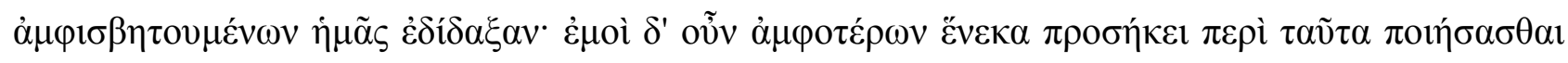

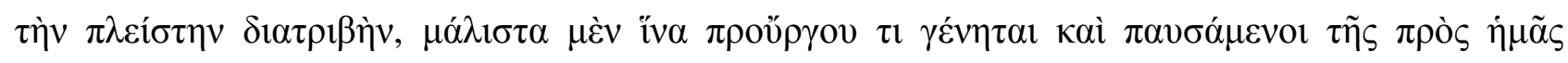

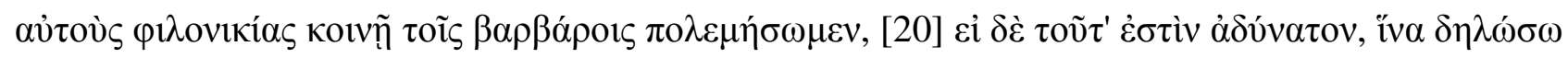

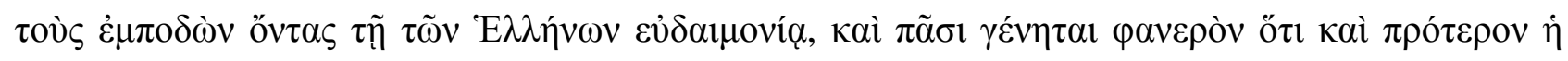

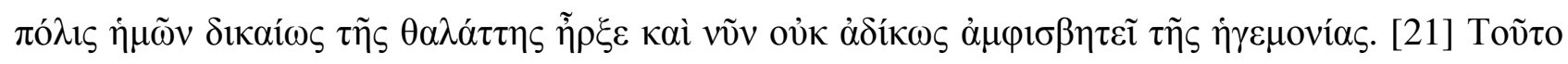

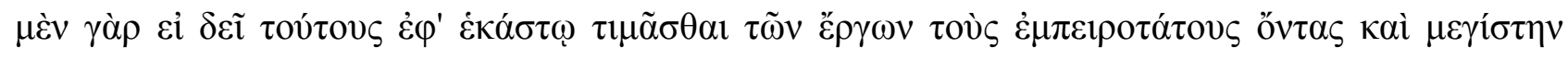

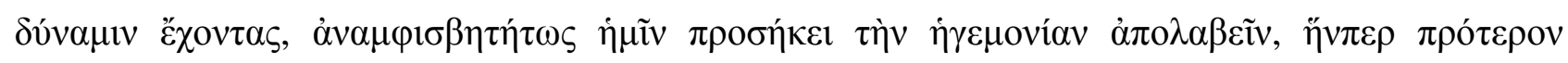

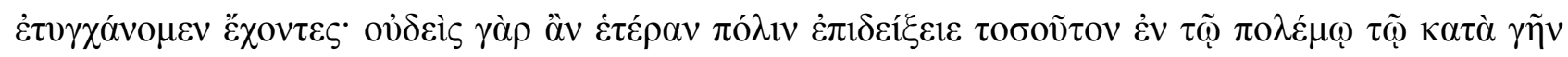




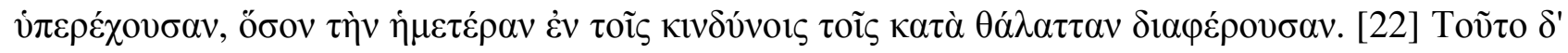

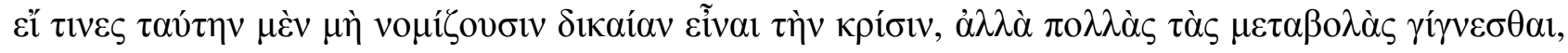

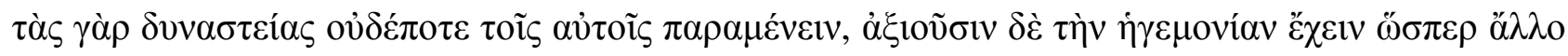

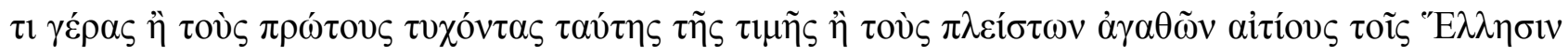

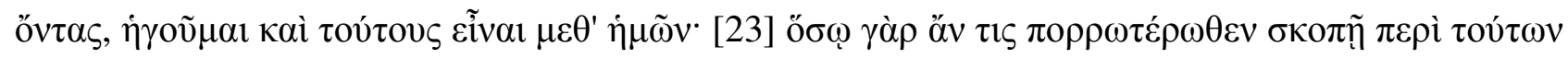

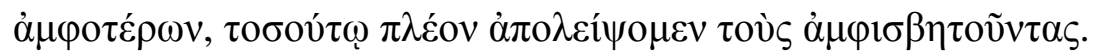

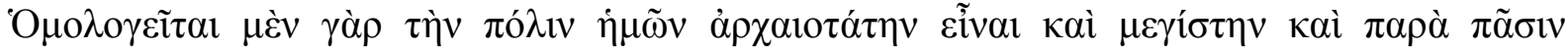

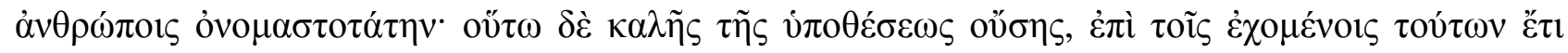

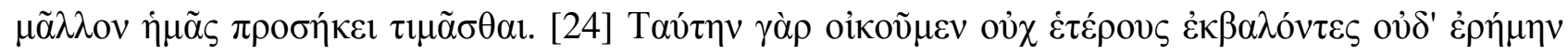

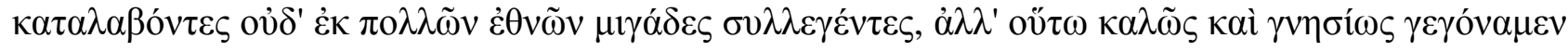

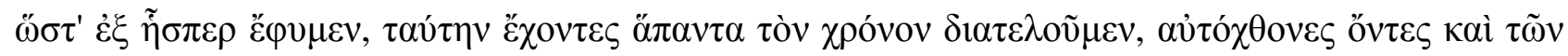

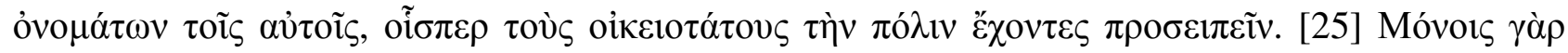

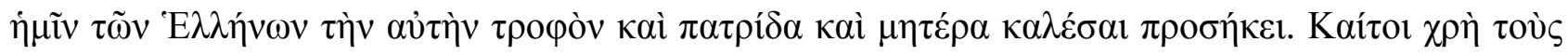

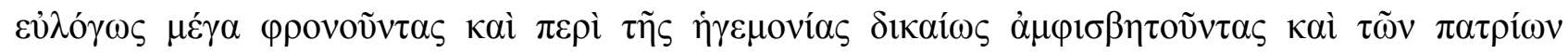

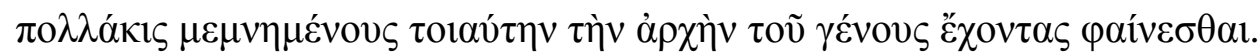

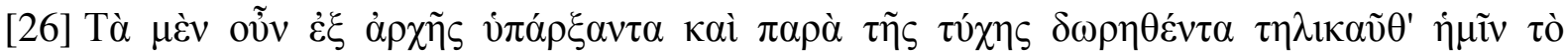

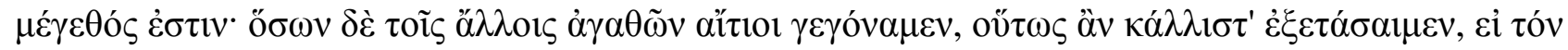

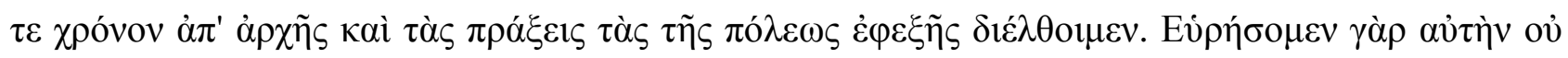

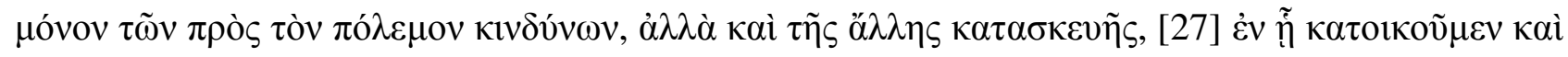

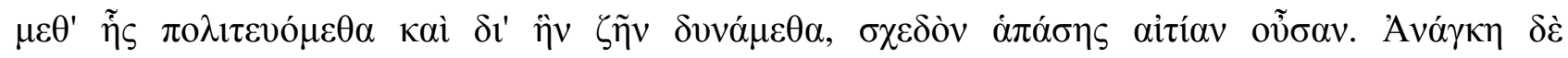

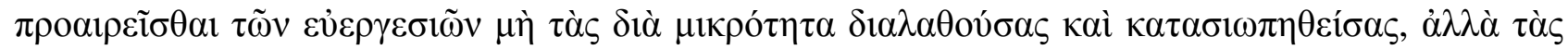

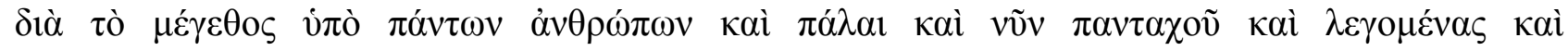
$\mu \vee \eta \mu о v \varepsilon v o \mu \varepsilon ́ v \alpha \varsigma$.

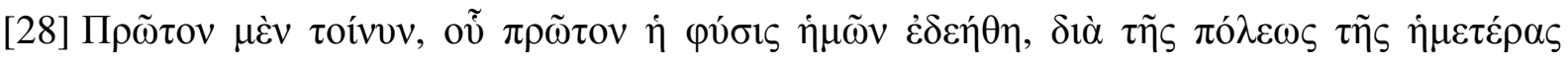

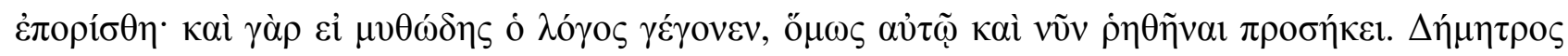




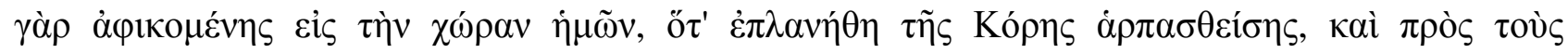

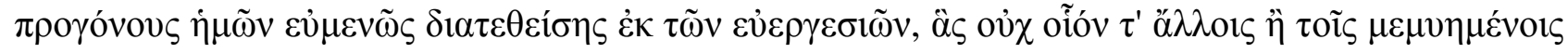

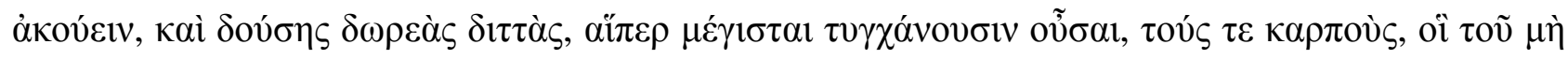

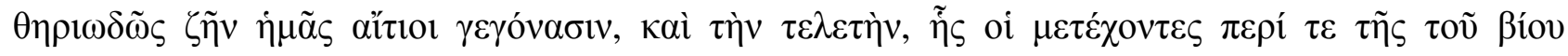

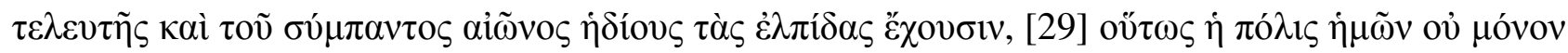

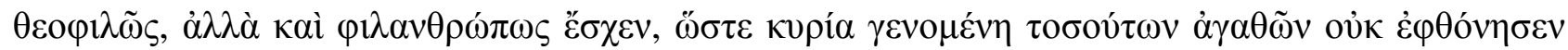

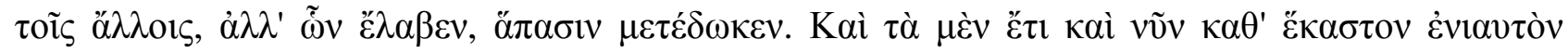

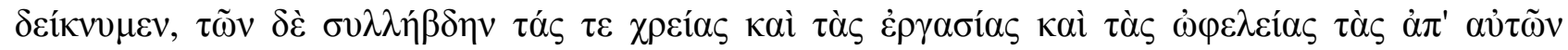

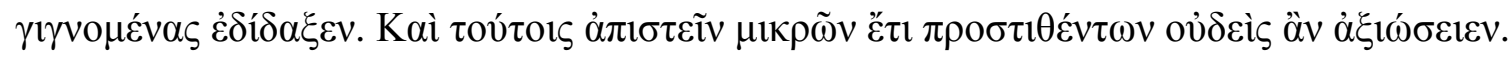

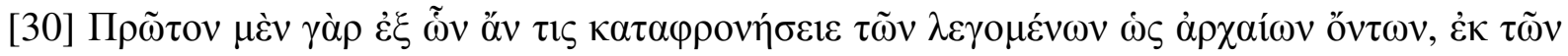

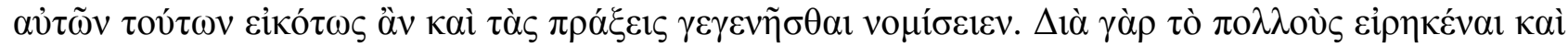

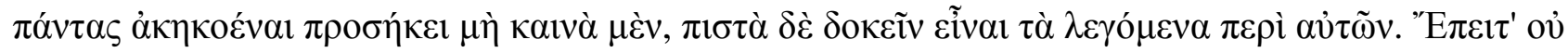

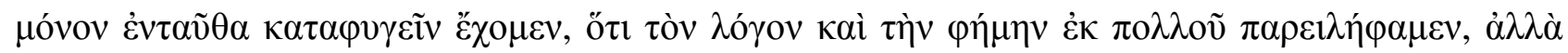

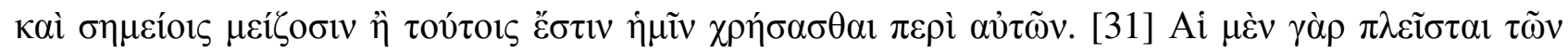

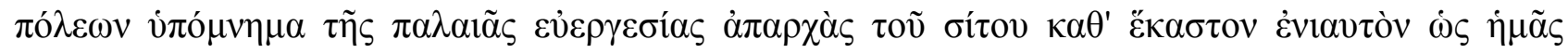

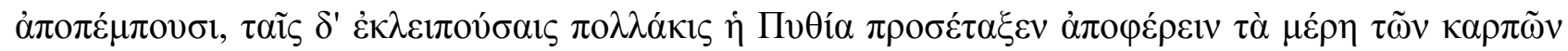

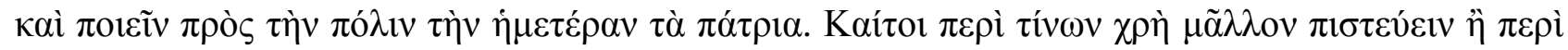

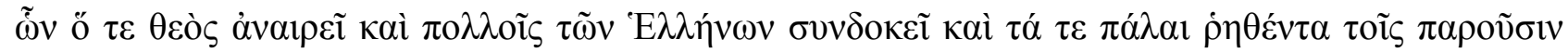

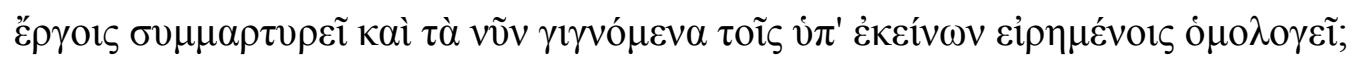

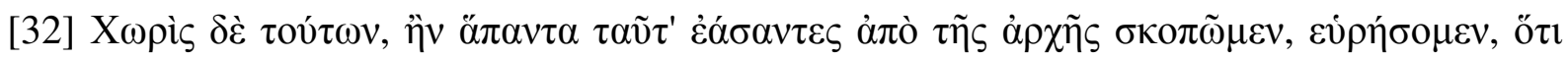

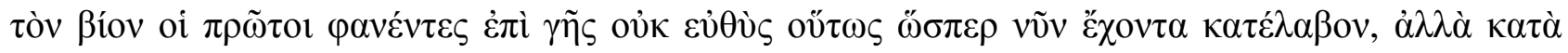

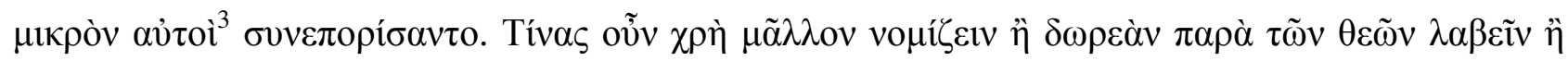

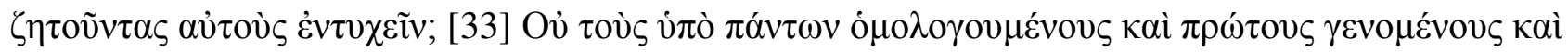

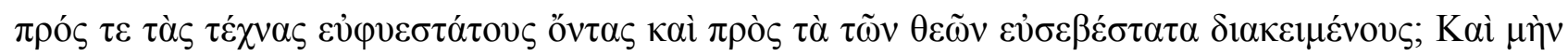

\footnotetext{
${ }^{3}$ Mandilaras: $\alpha$ $\tau o \tilde{c}$.
} 


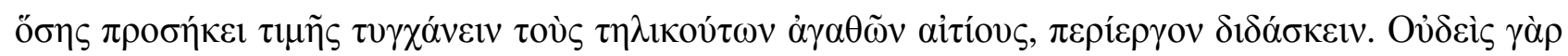

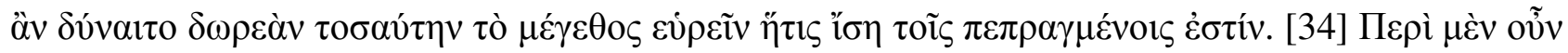

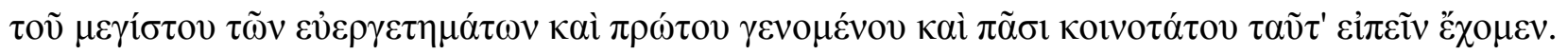

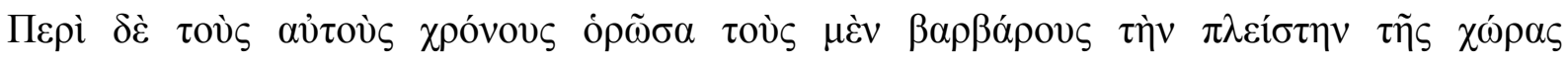

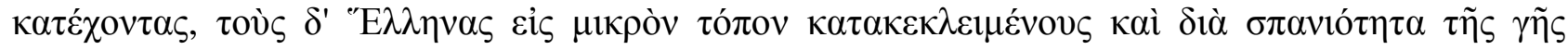

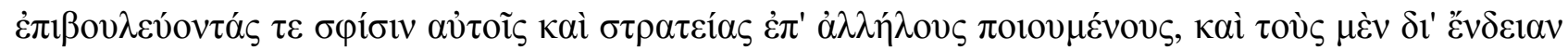

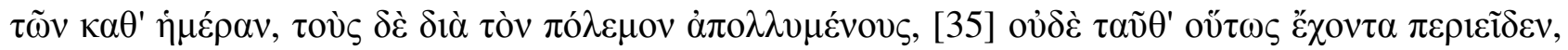

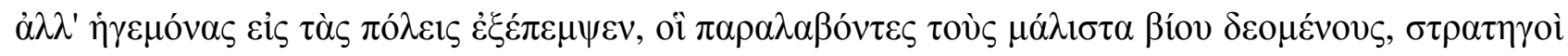

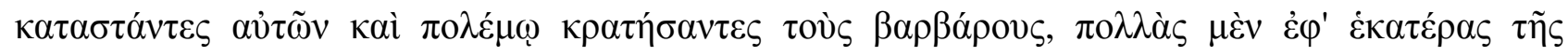

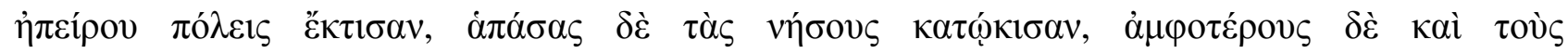

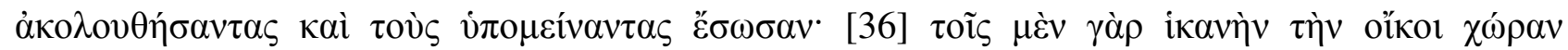

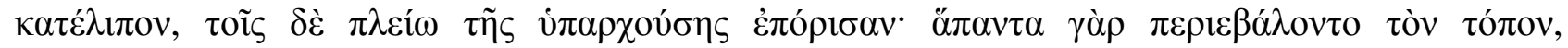

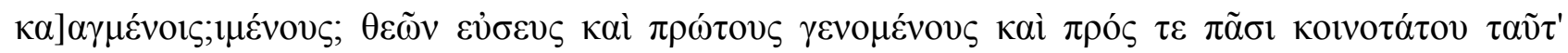

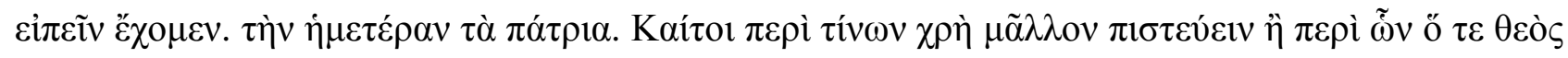

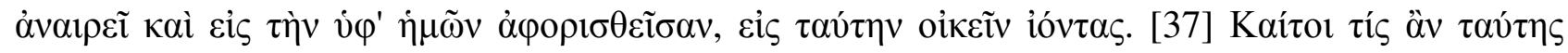

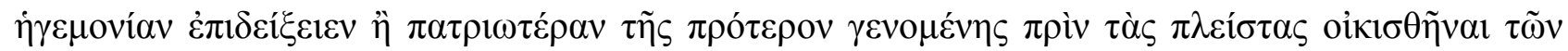

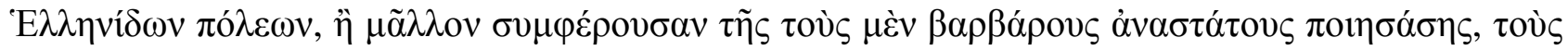

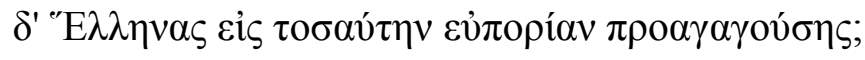

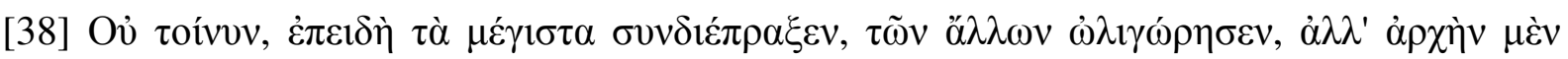

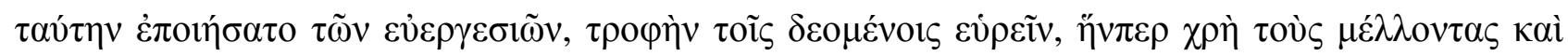

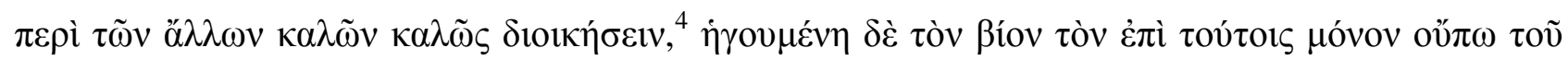

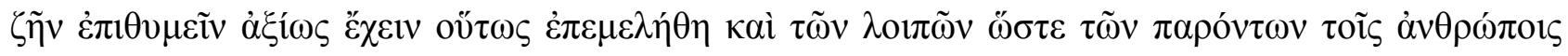

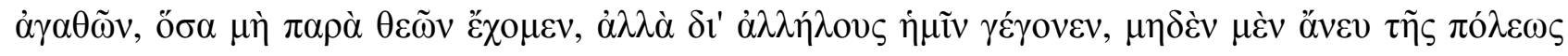

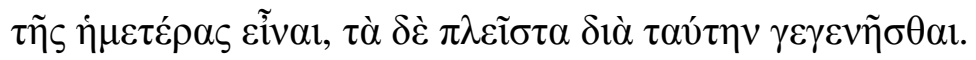

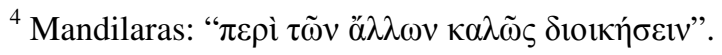




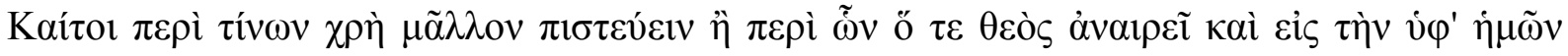

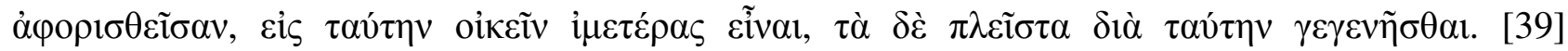

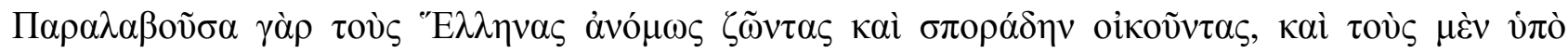

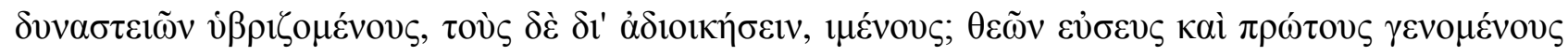

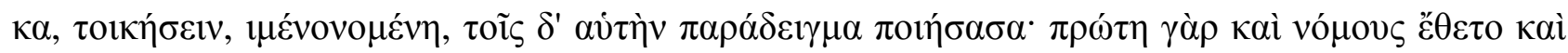

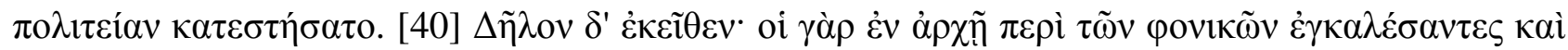

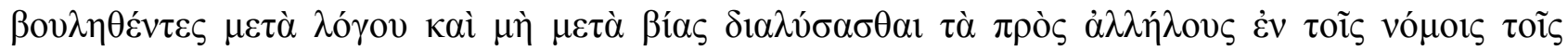

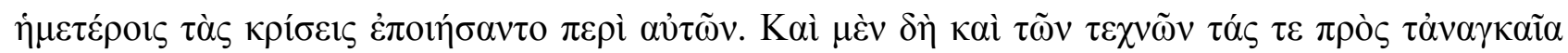

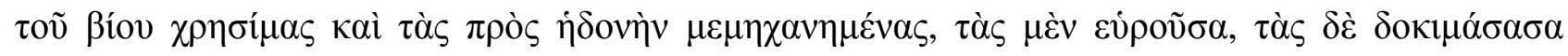

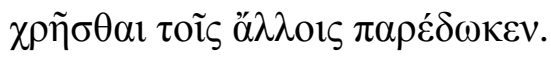

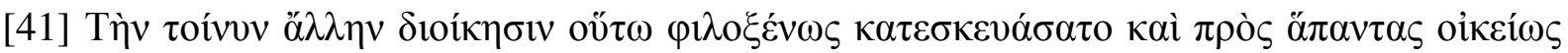

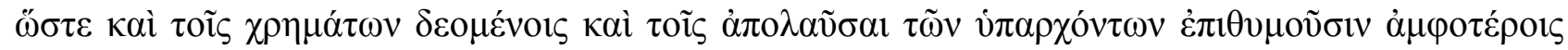

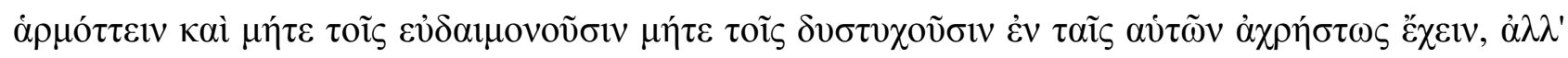

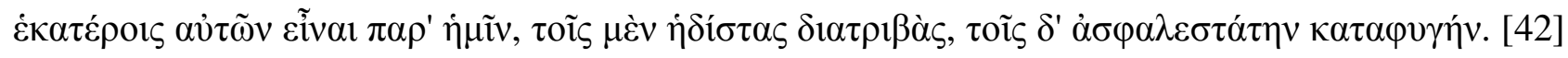

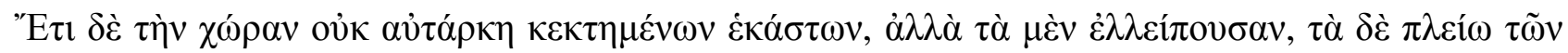

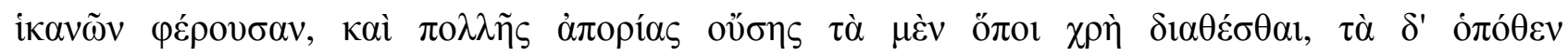

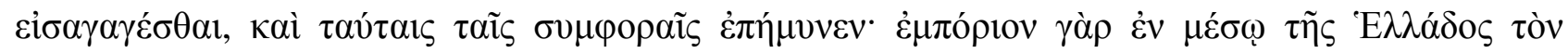

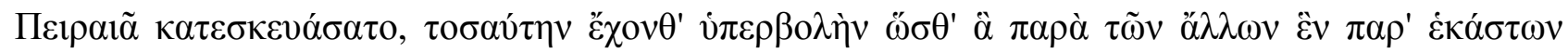

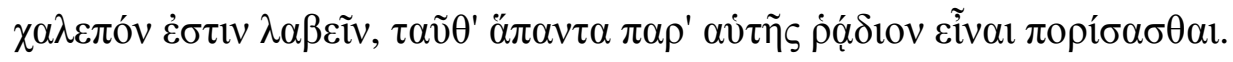

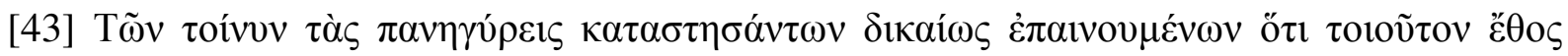

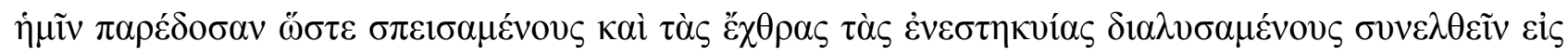

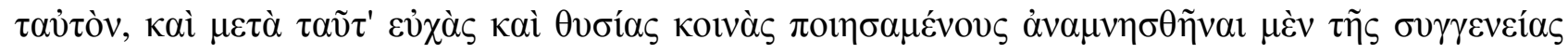

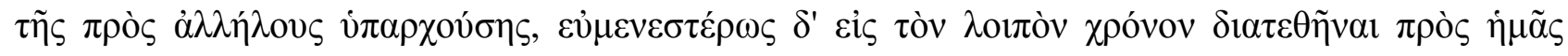

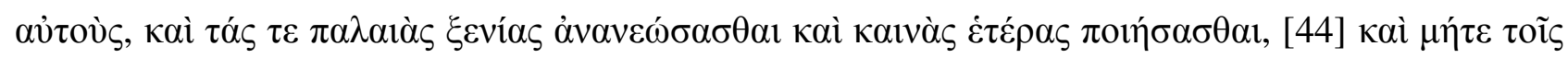

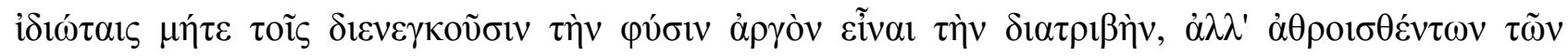




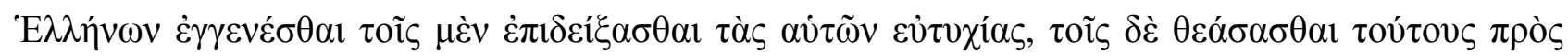

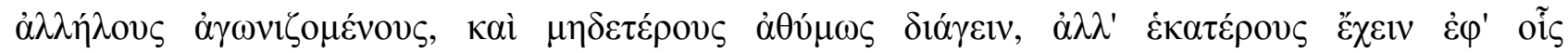

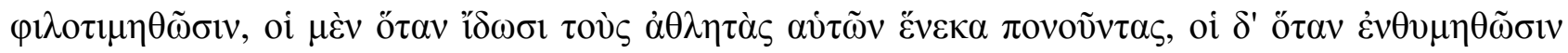

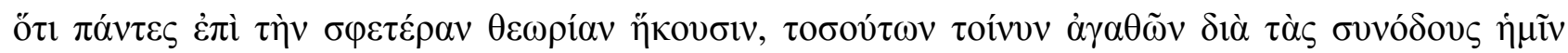

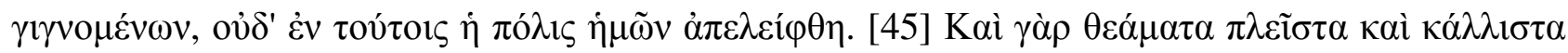

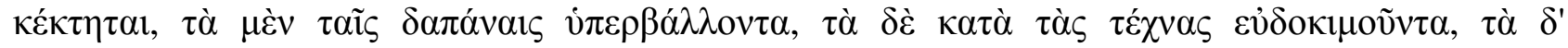

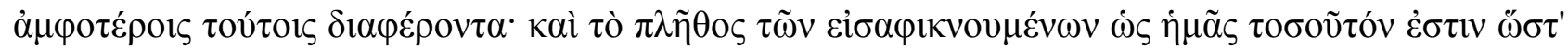

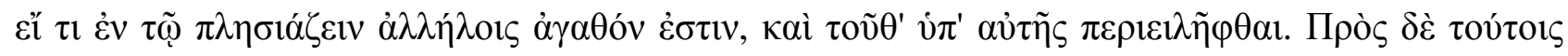

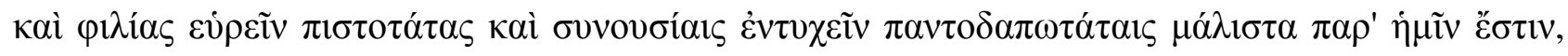

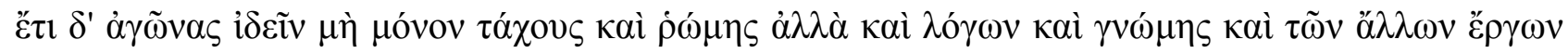

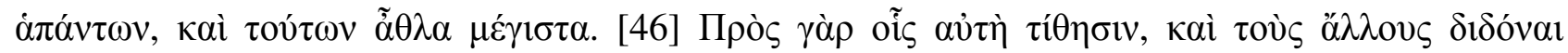

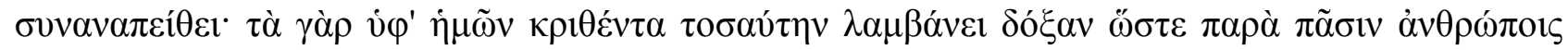

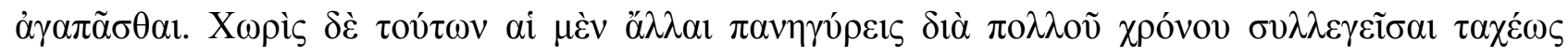

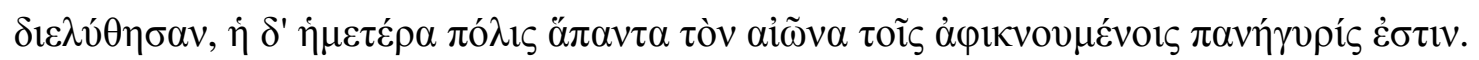

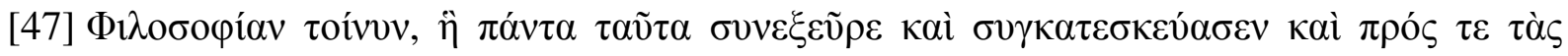

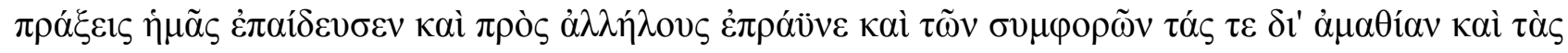

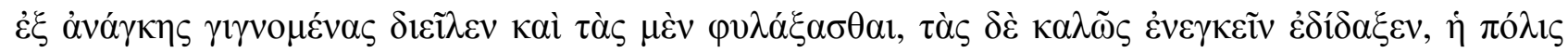

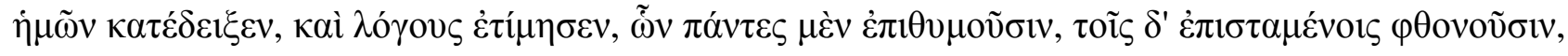

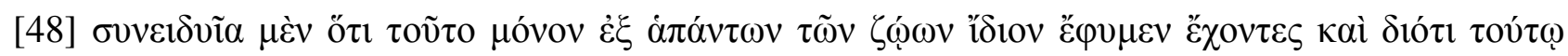

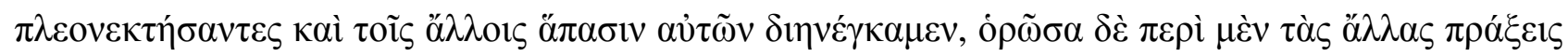

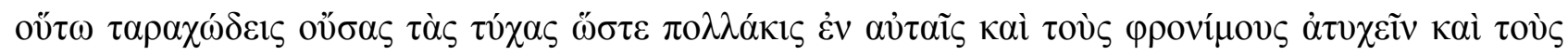

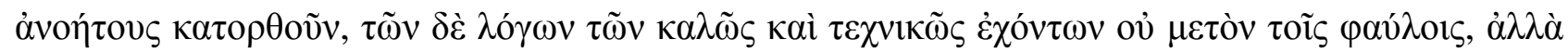

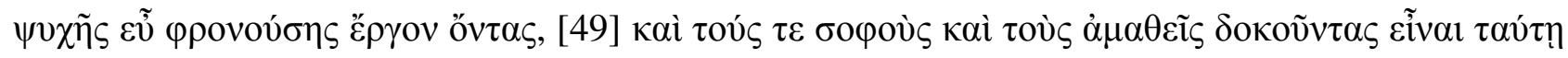

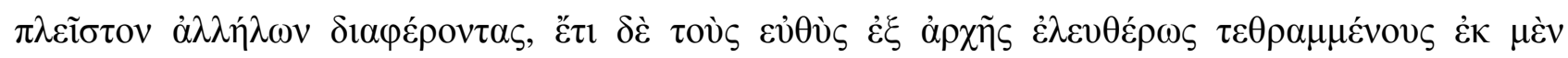

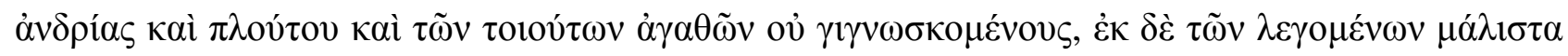




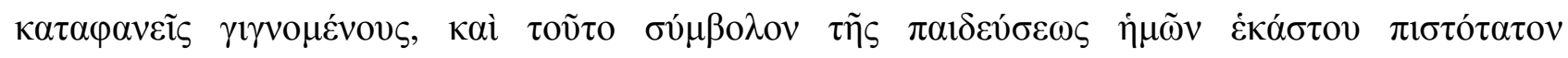

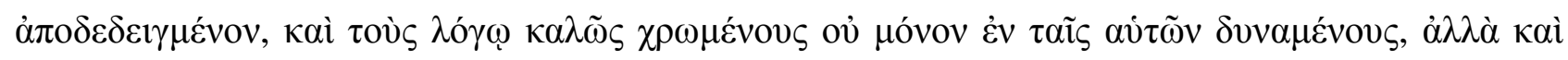

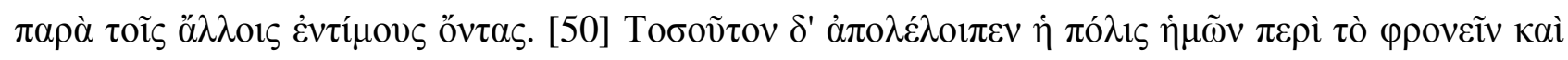

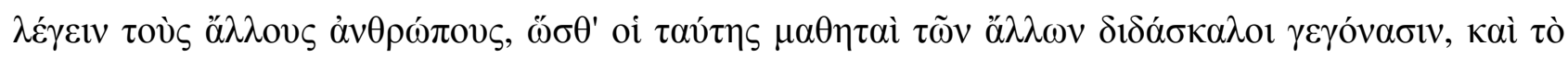

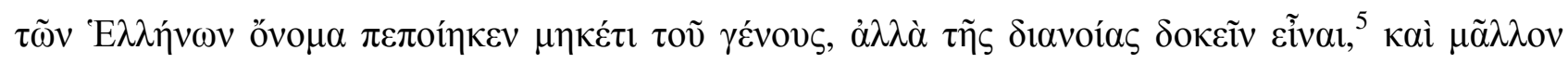

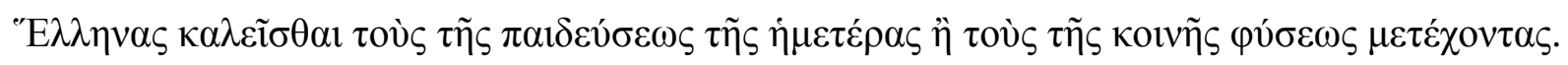

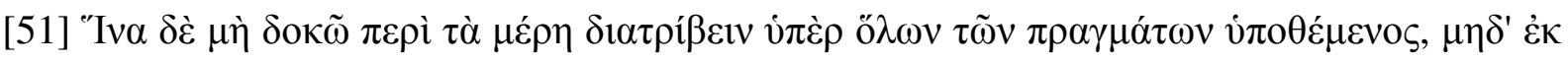

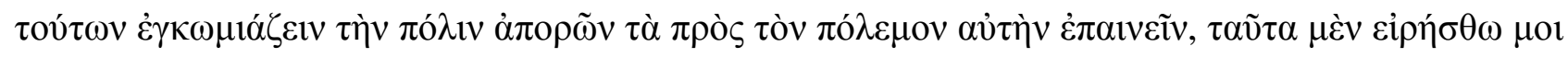

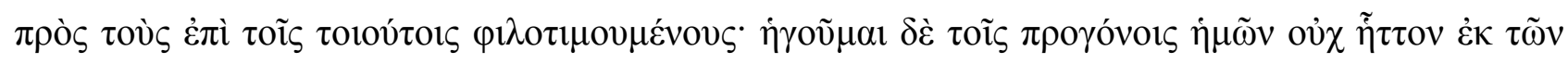

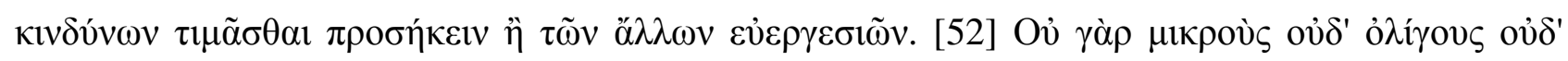

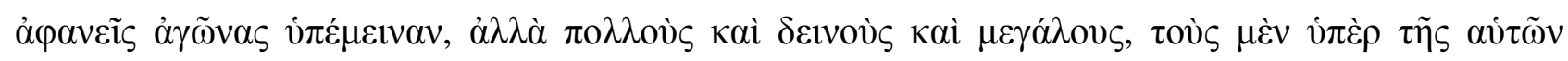

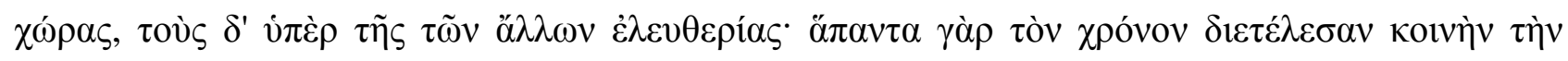

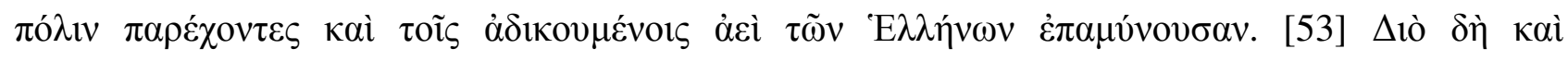

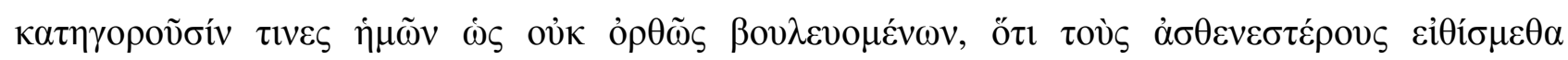

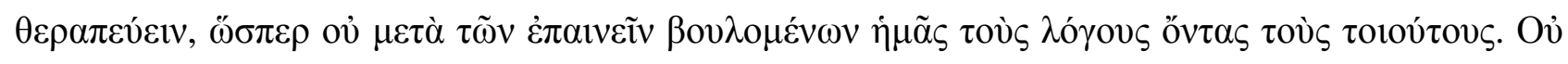

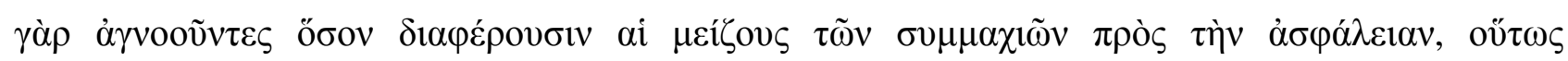

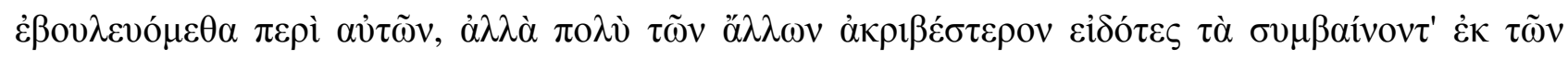

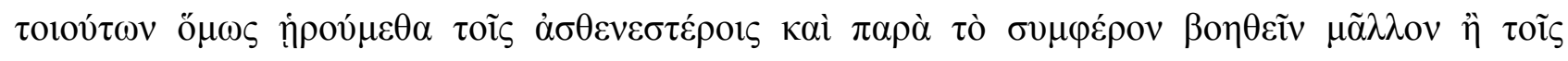

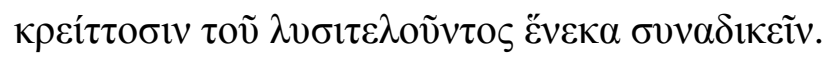

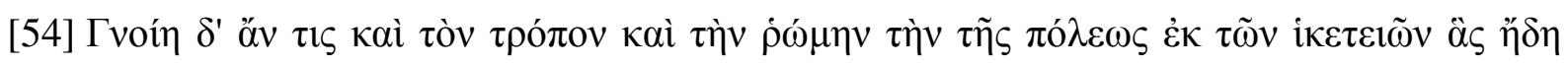

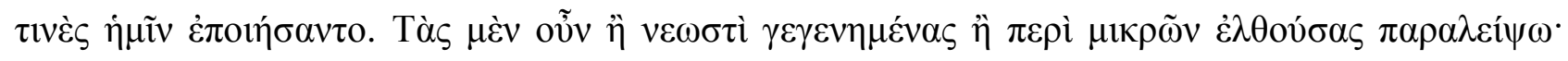

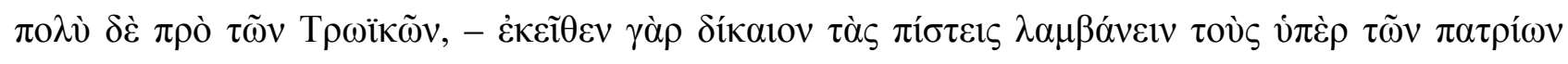

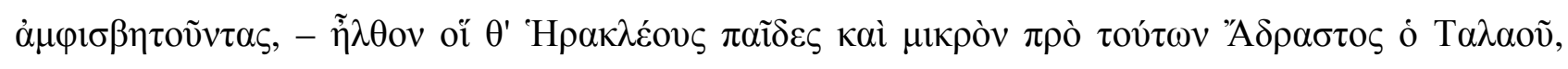

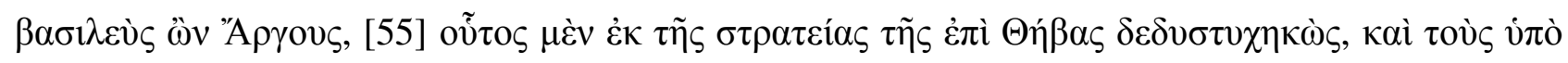

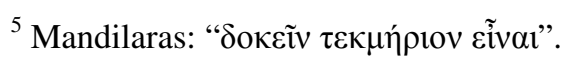




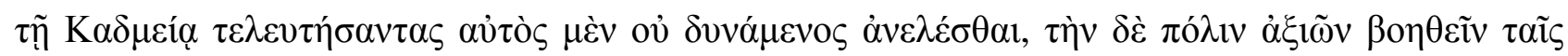

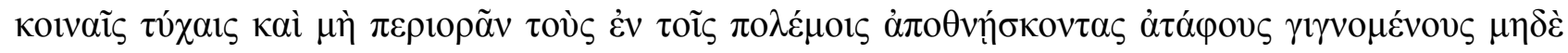

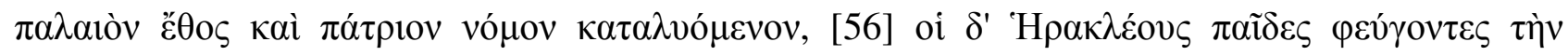

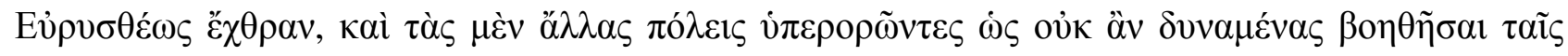

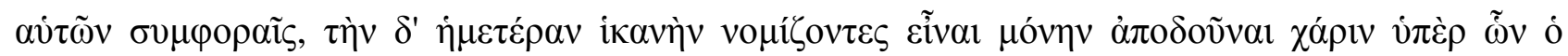

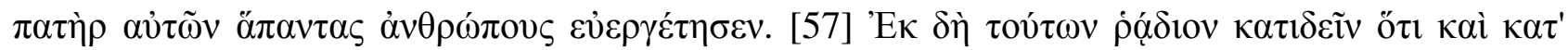

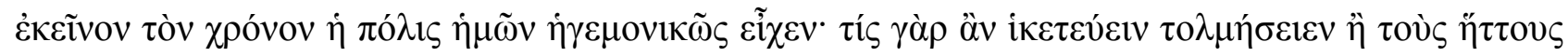
$\alpha$

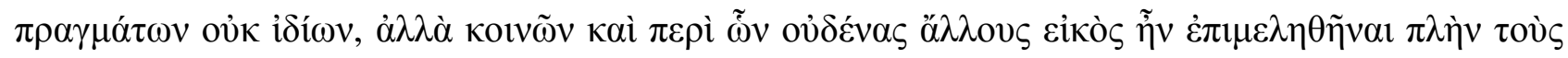

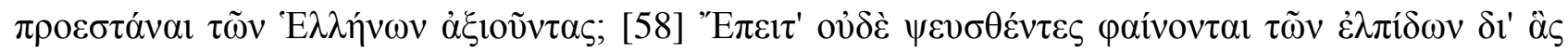

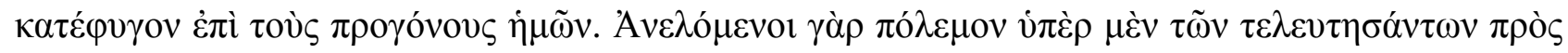

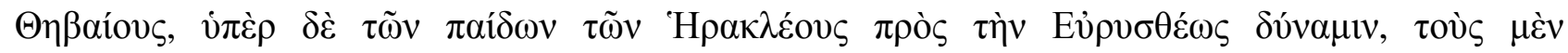

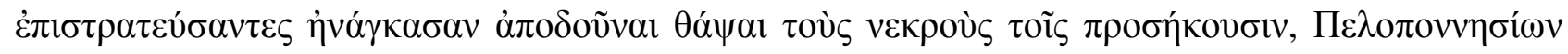

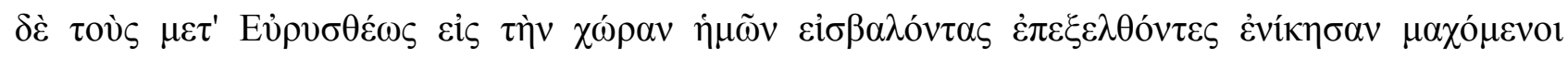

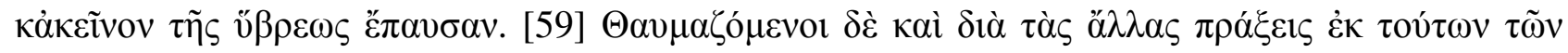

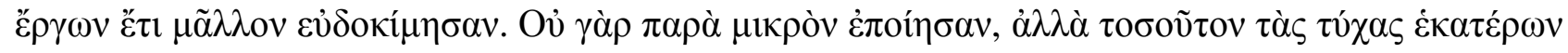

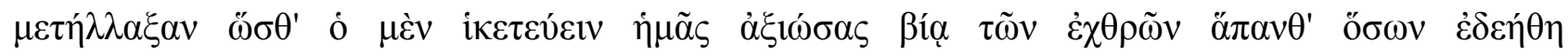

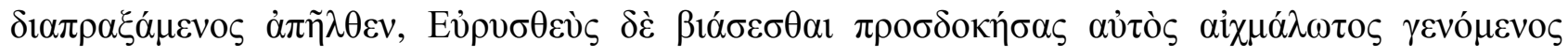

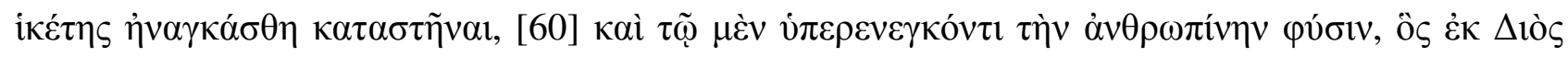

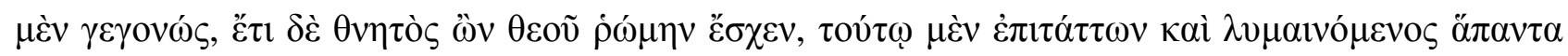

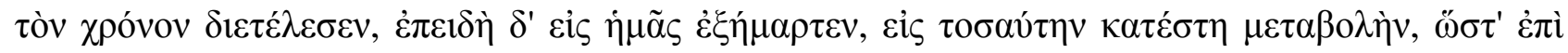

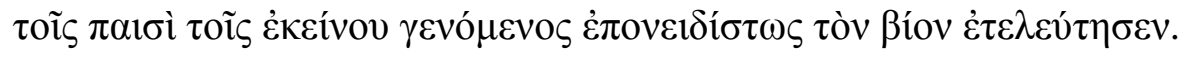

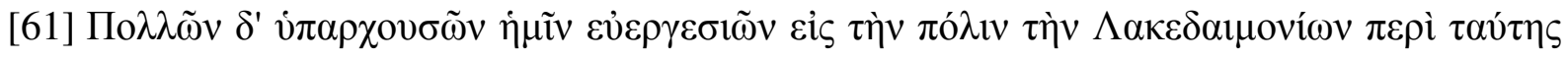

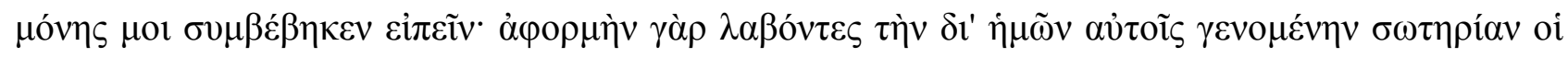

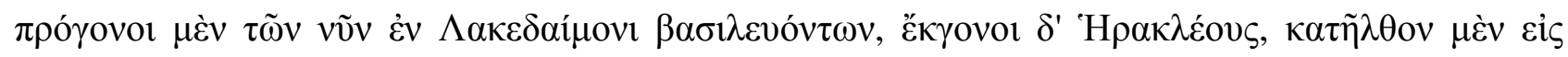




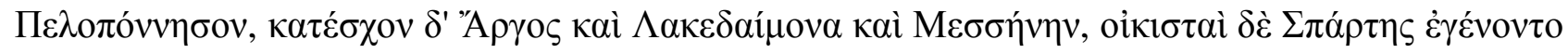

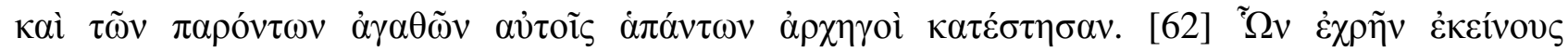

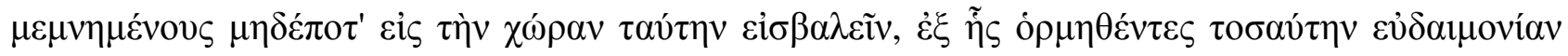

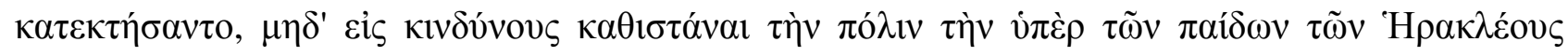

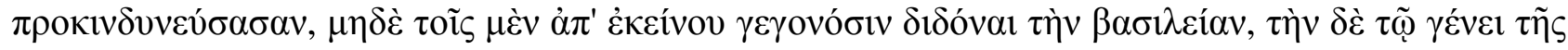

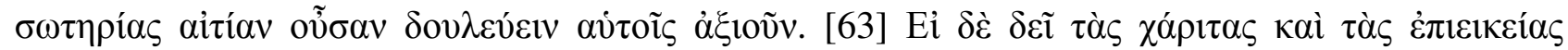

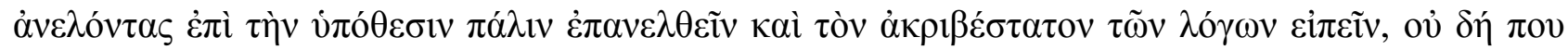

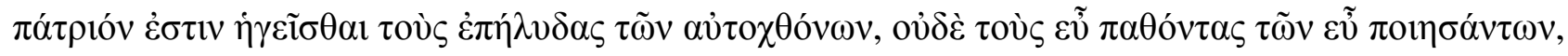

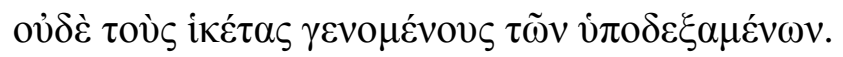

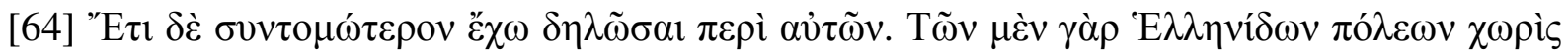

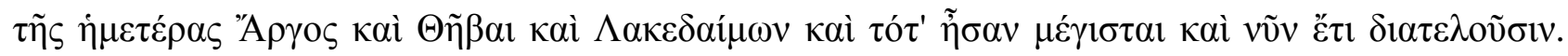

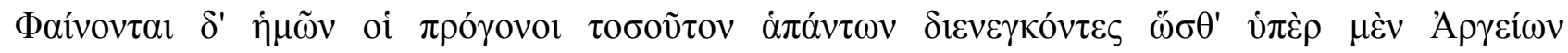

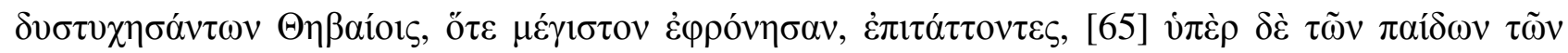

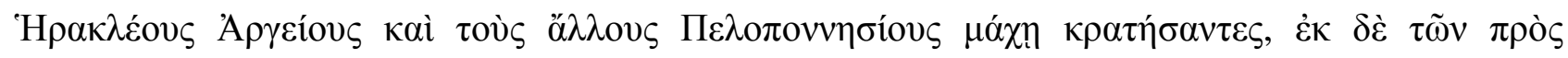

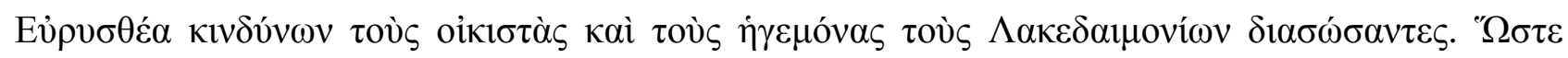

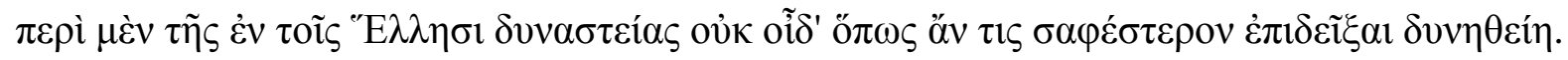

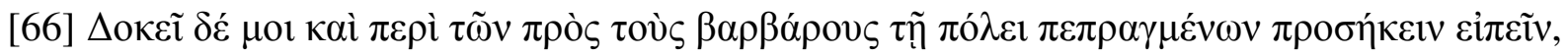

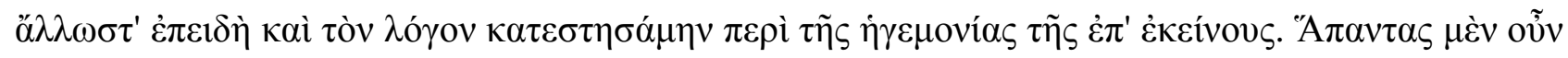

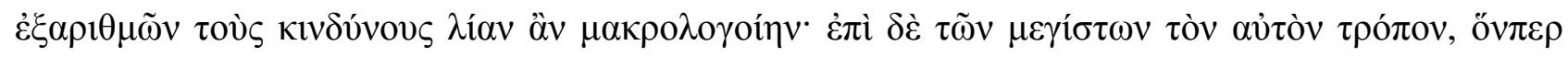

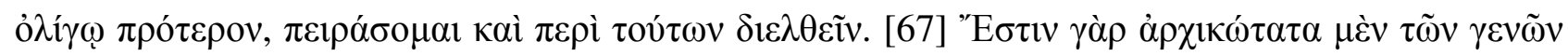

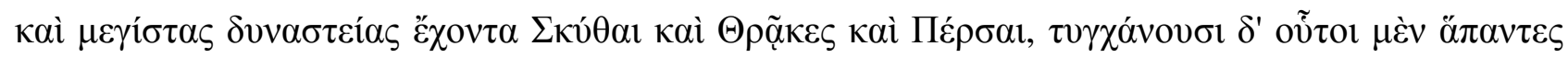

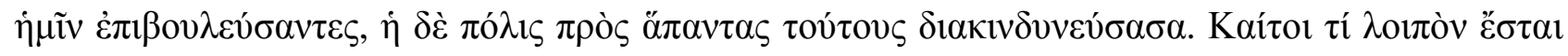

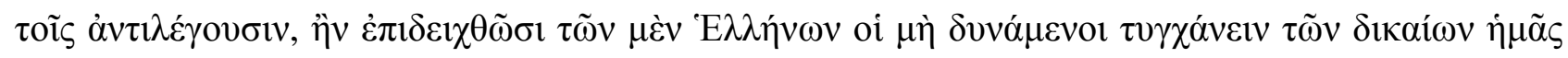

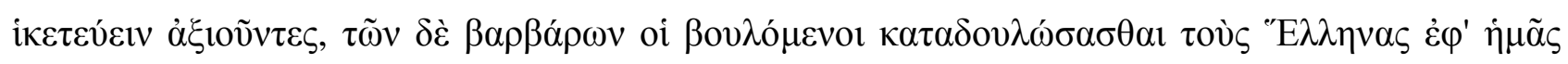

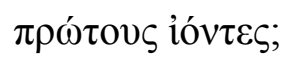




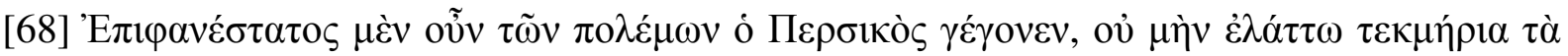

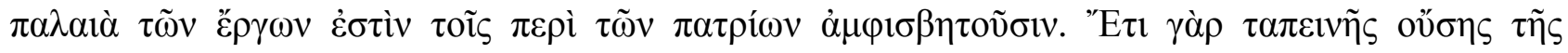

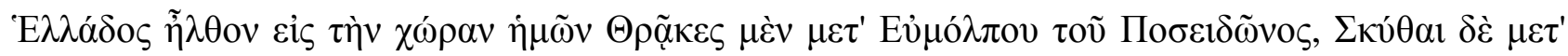

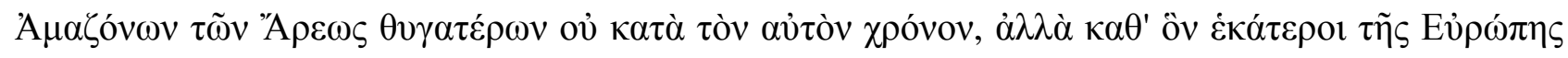

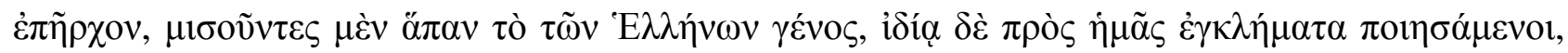

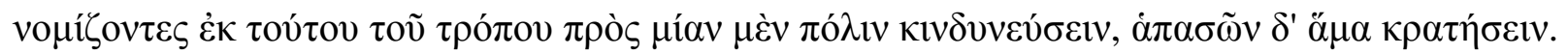

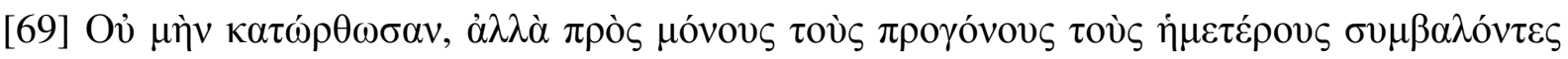

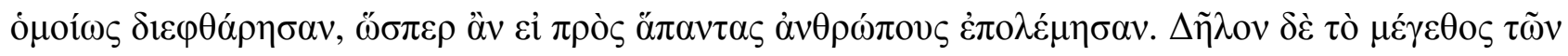

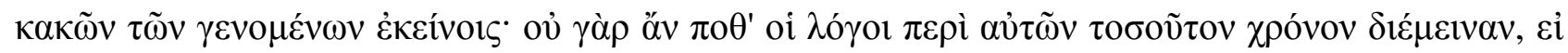

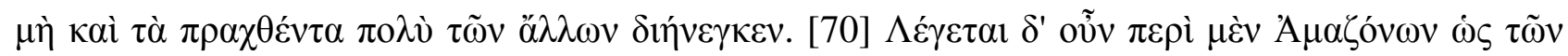

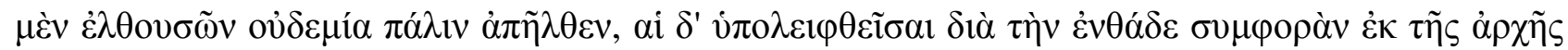

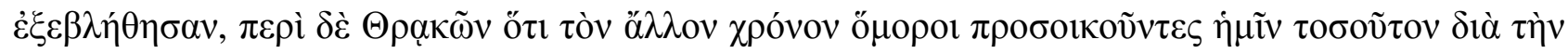

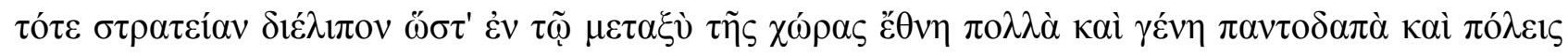

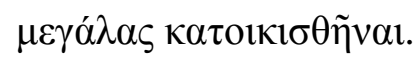

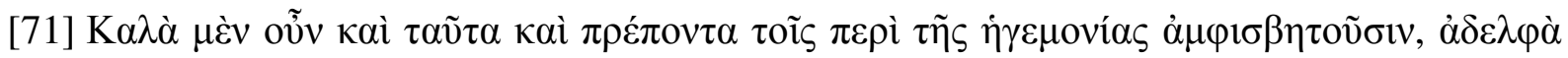

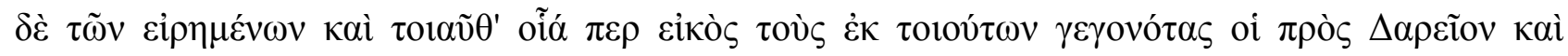

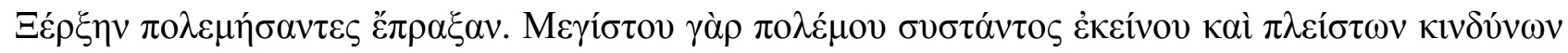

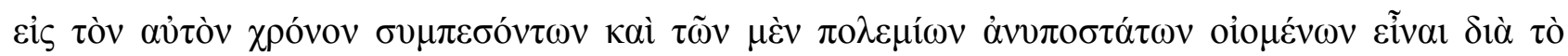

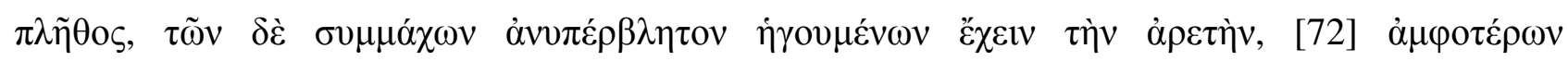

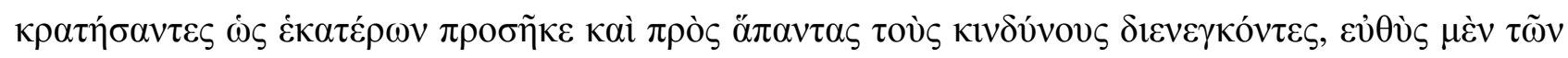

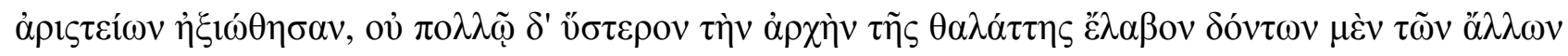

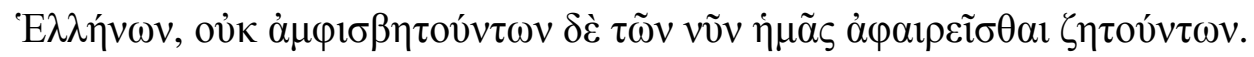

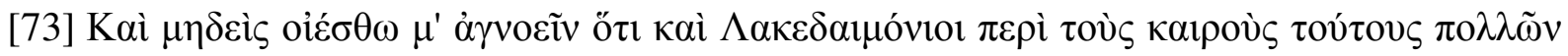

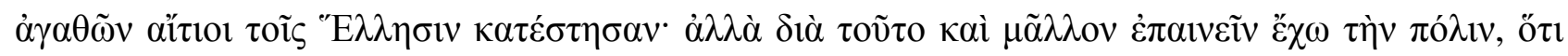

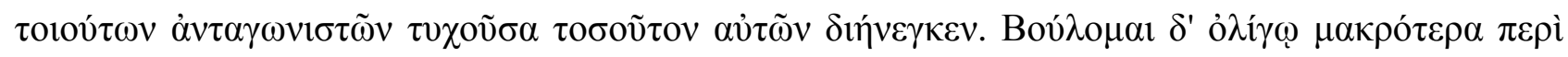




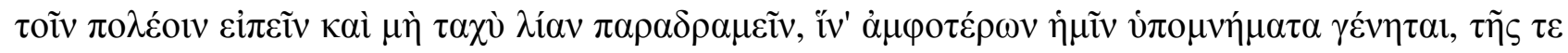

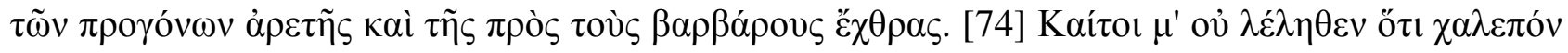

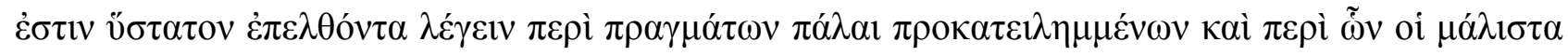

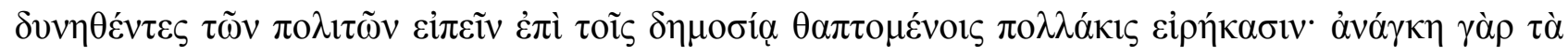

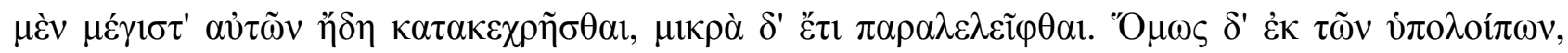

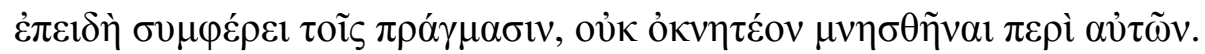

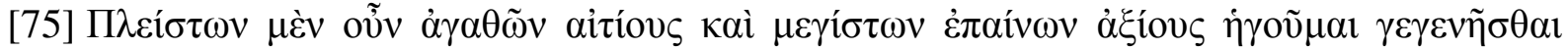

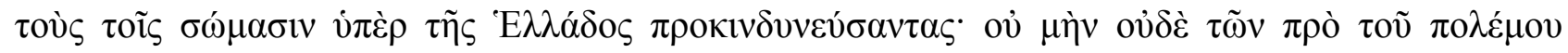

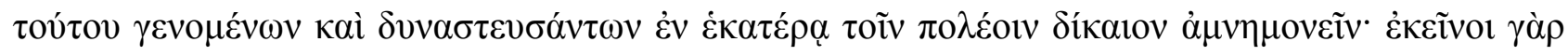

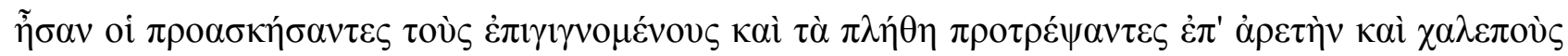

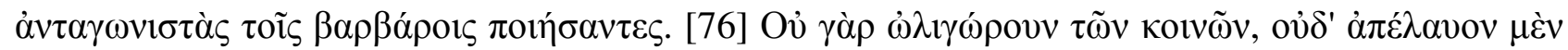

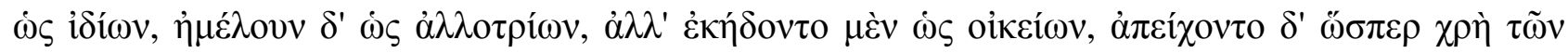

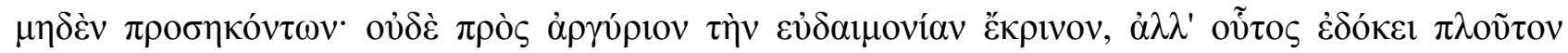

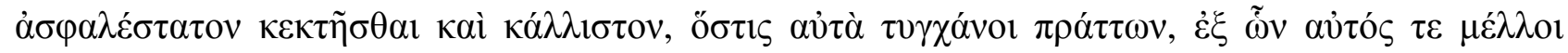

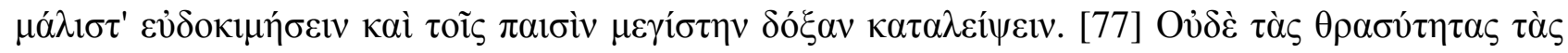

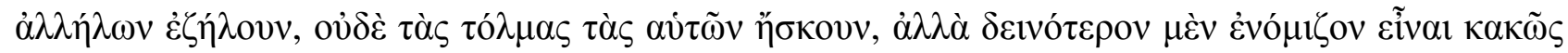

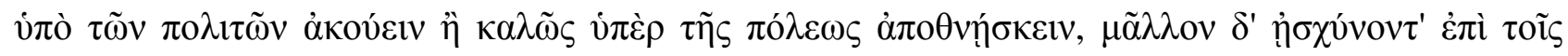

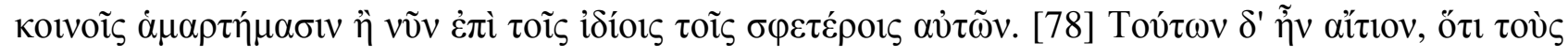

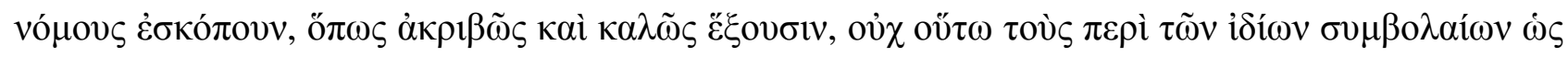

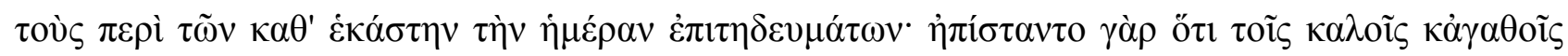

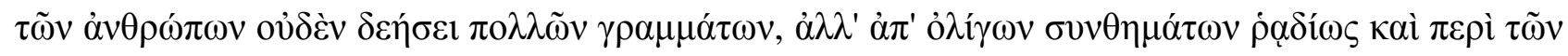

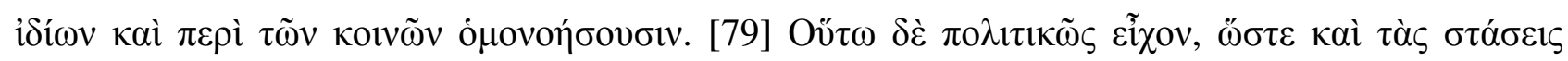

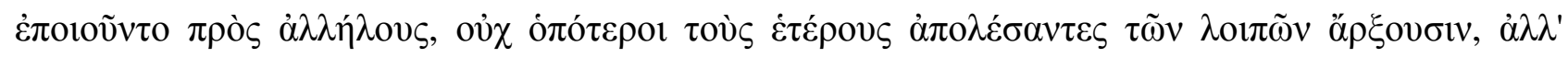

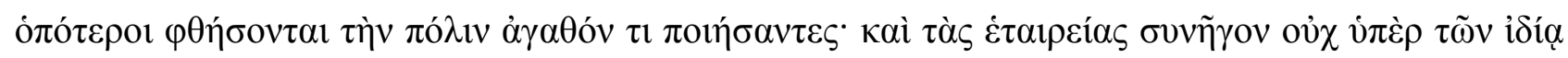

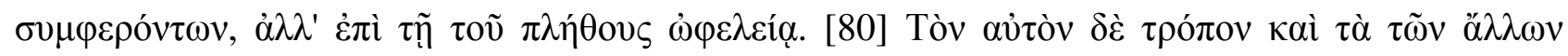




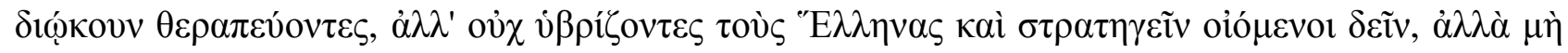

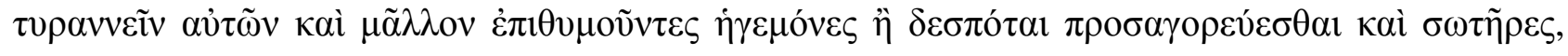

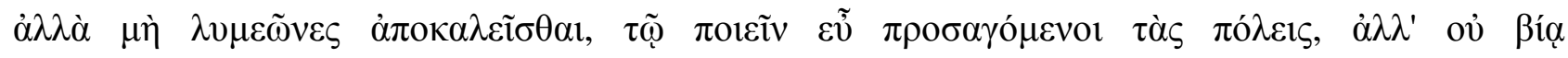

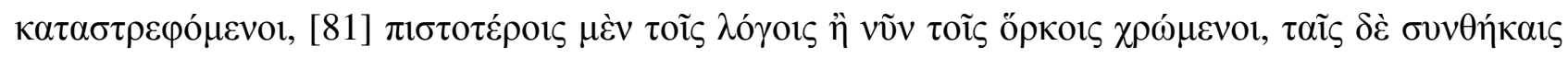

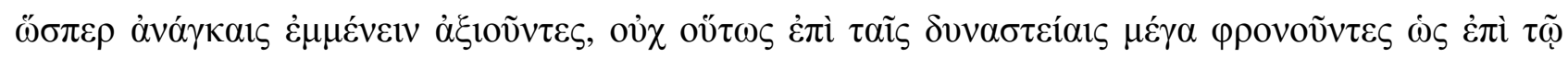

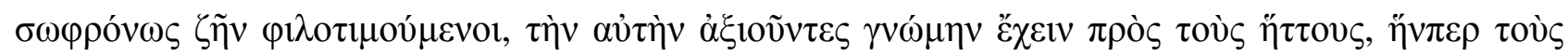

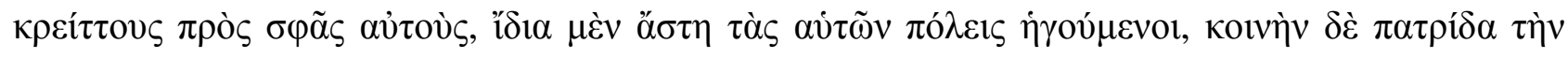

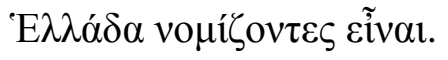

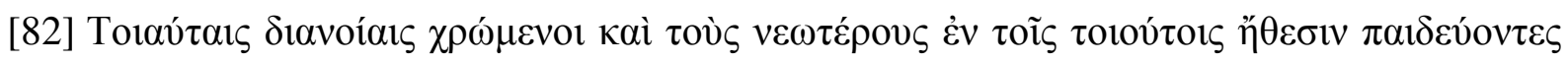

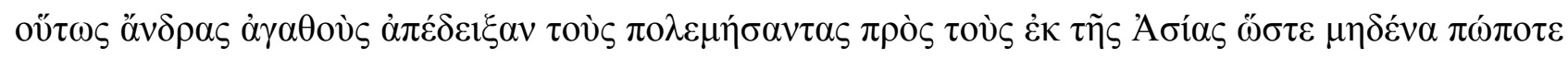

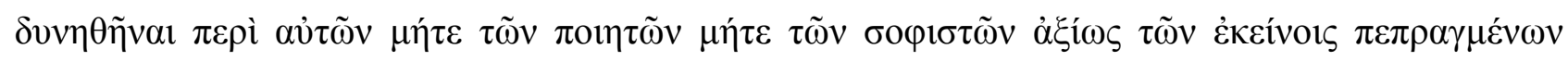

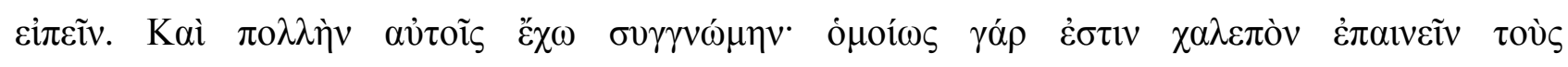

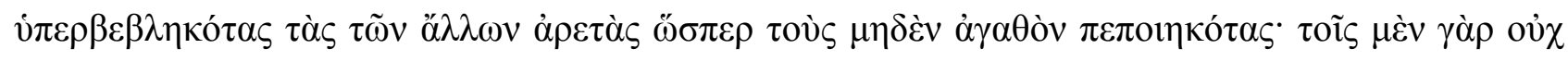

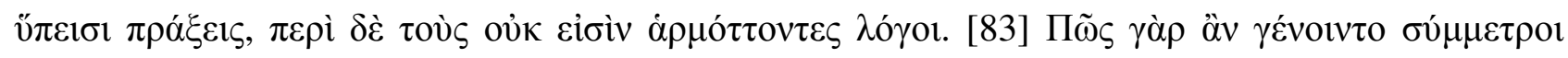

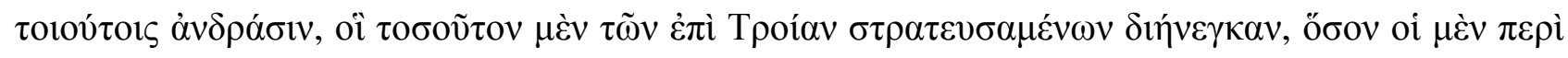

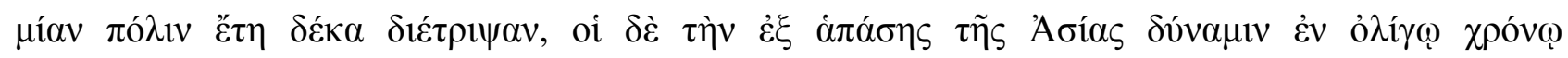

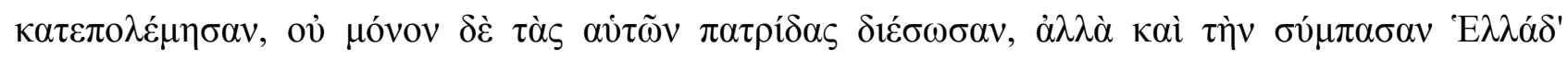

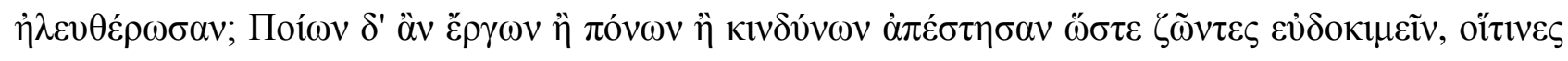

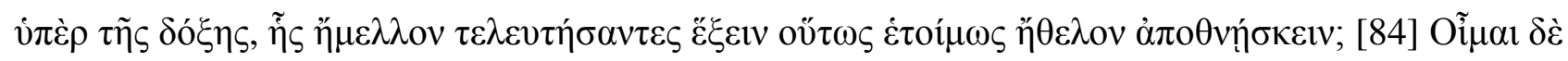

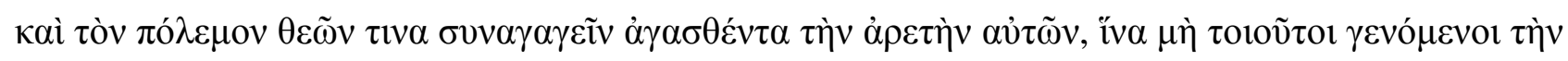

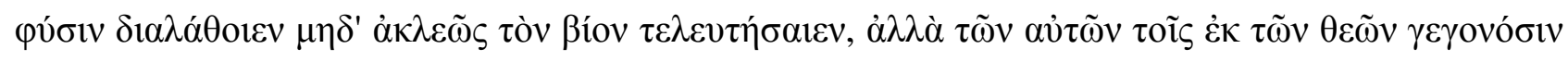

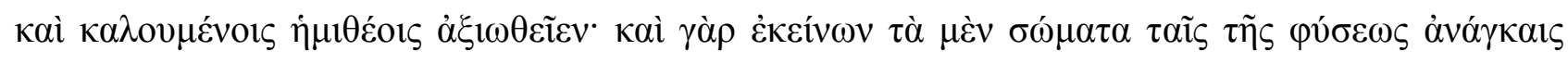

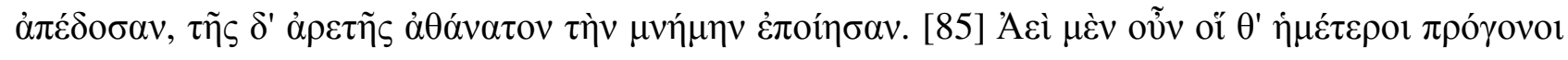

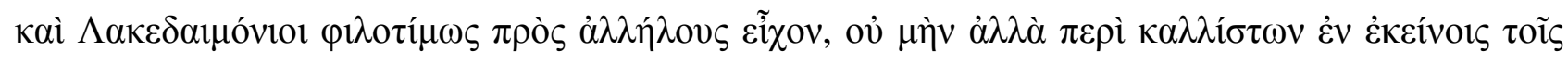

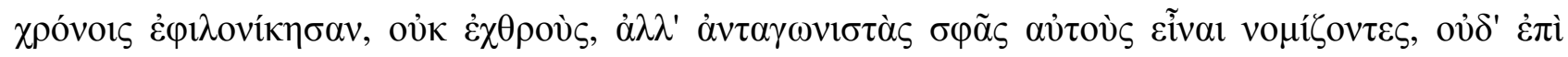




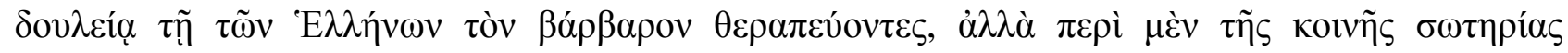

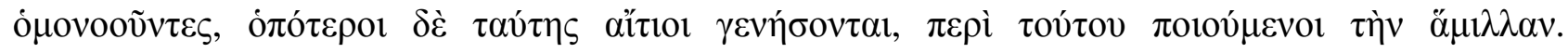

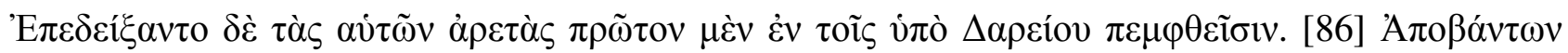

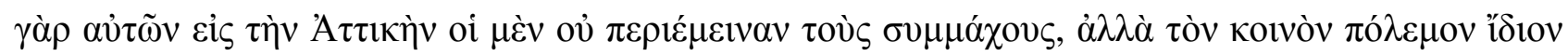

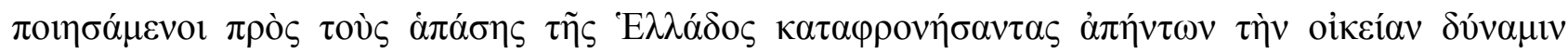

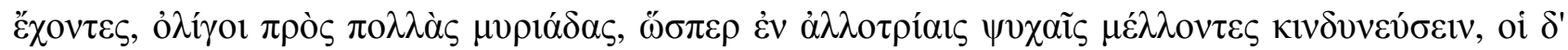

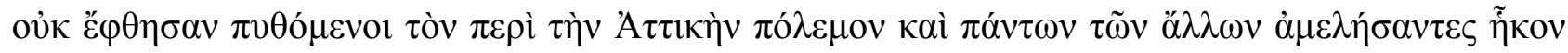

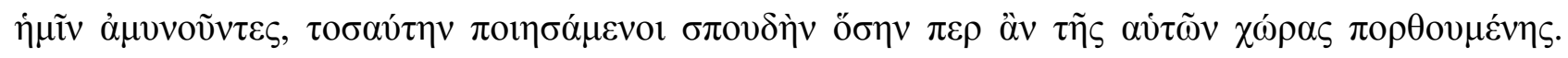

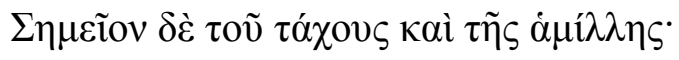

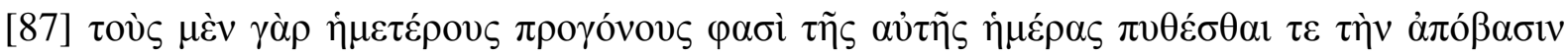

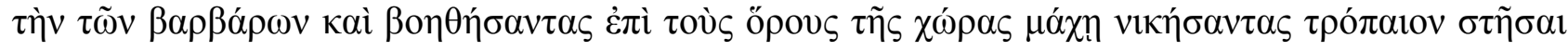

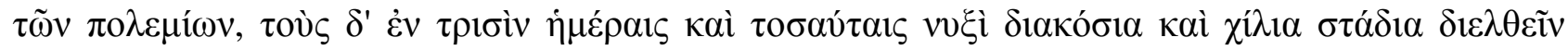

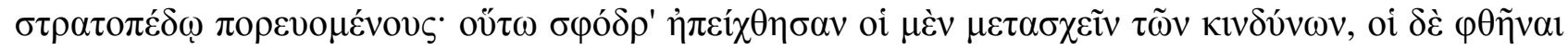

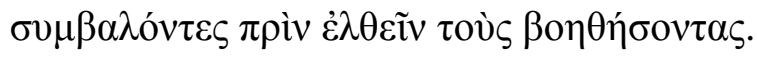

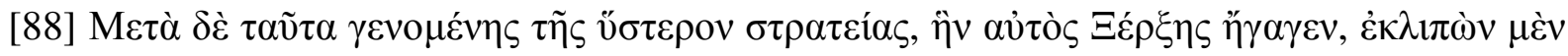

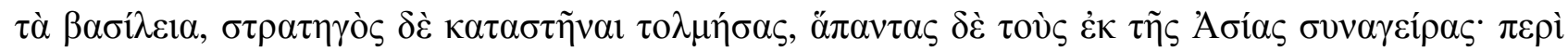

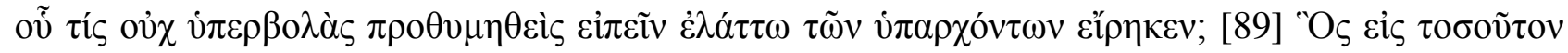

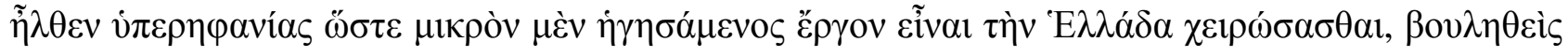

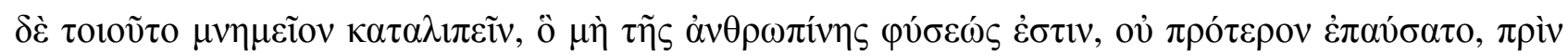

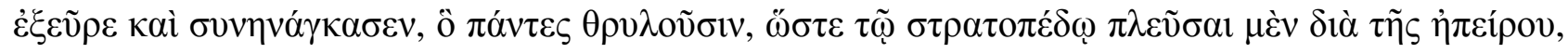

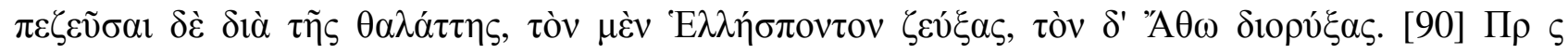

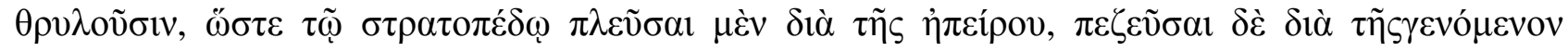

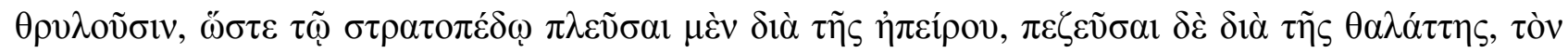

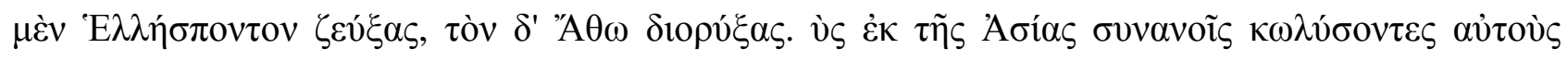

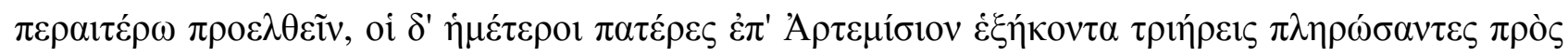




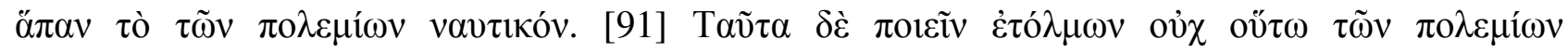

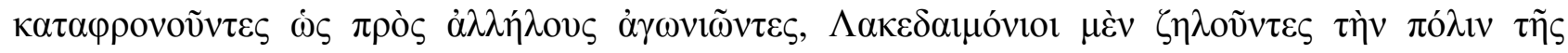

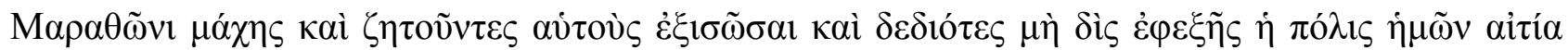

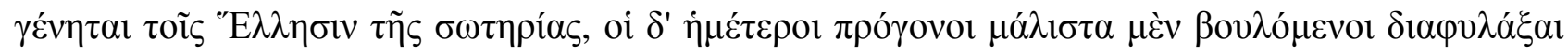

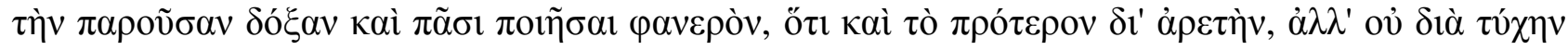

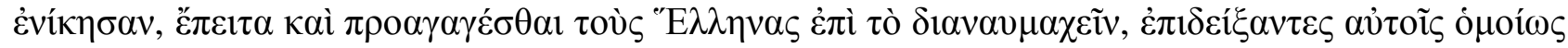

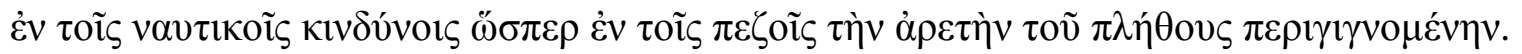

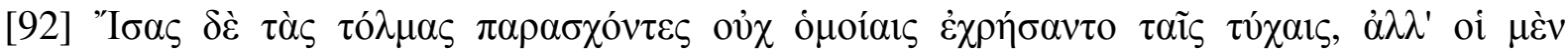

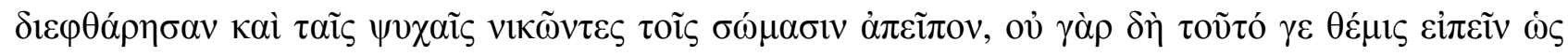

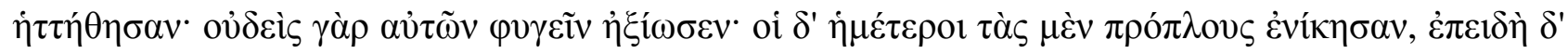

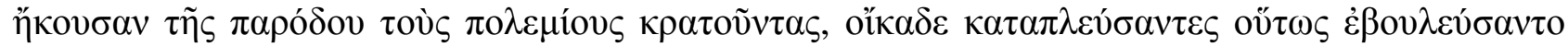

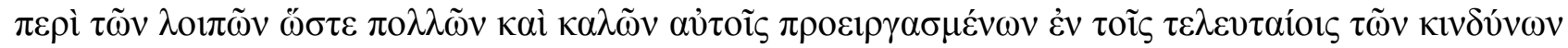

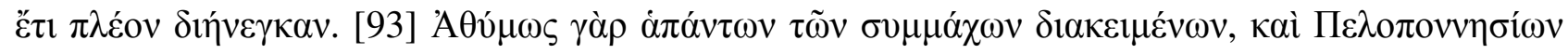

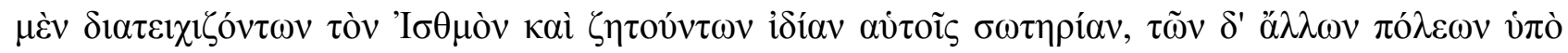

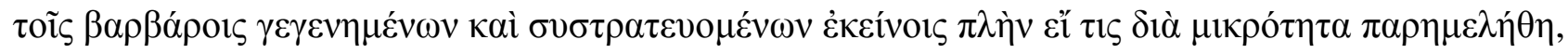

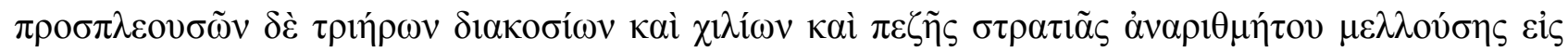

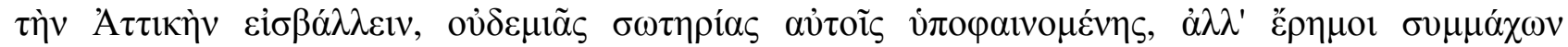

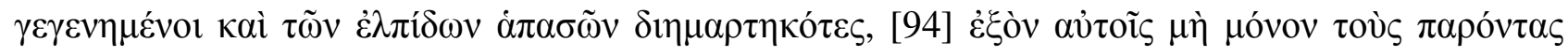

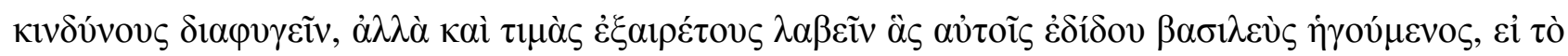

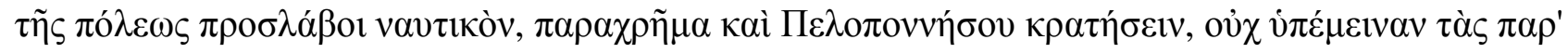

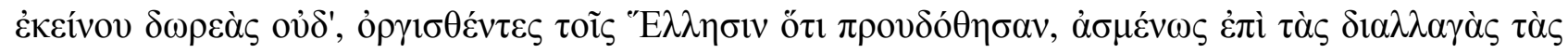

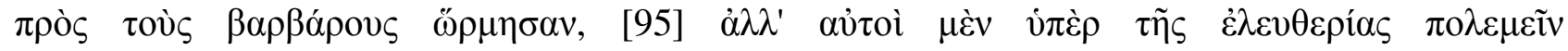

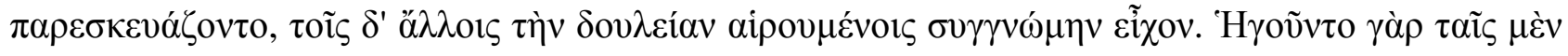

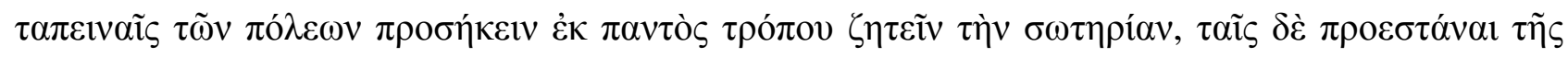

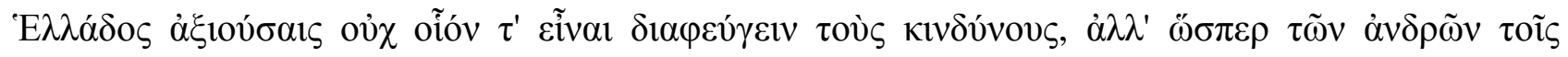




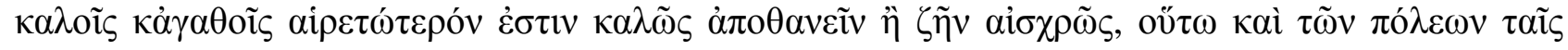

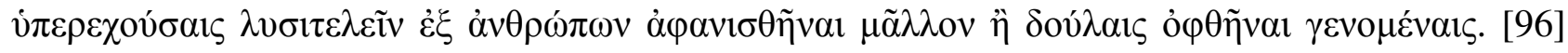

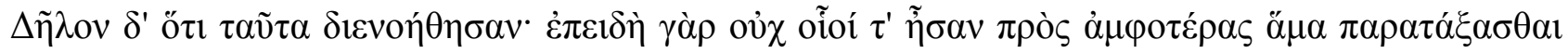

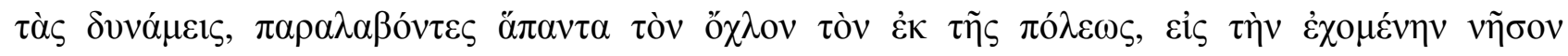

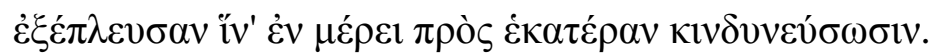

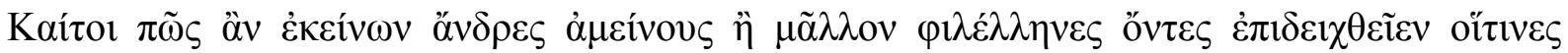

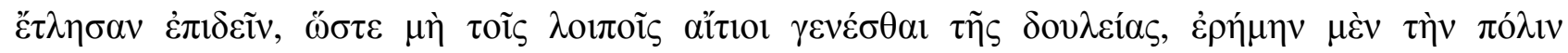

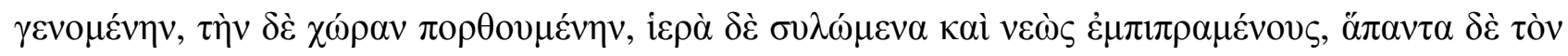

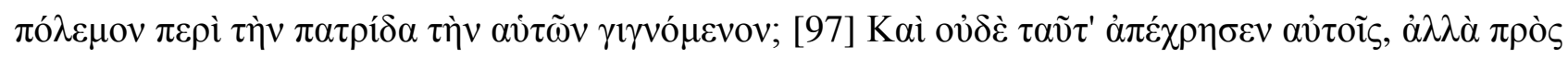

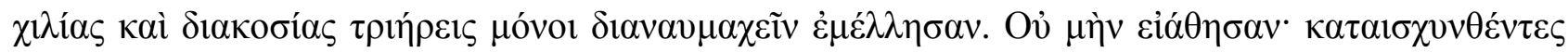

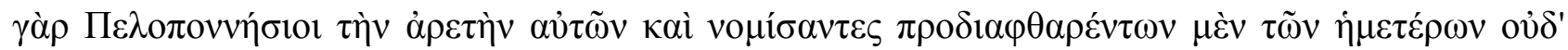

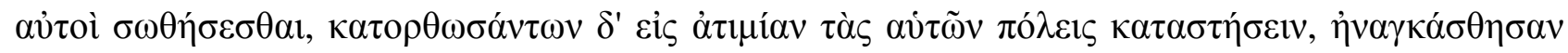

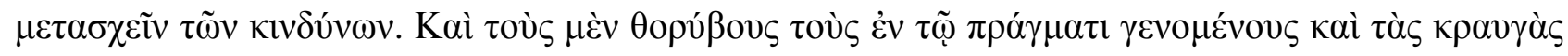

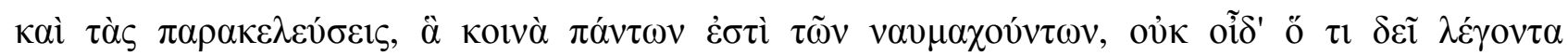

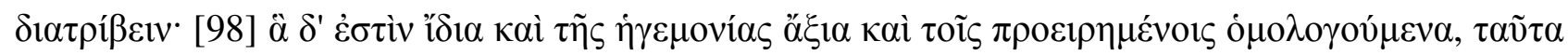

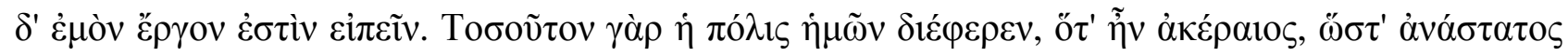

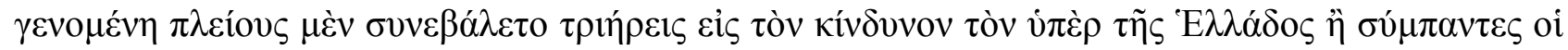

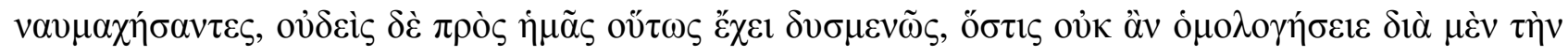

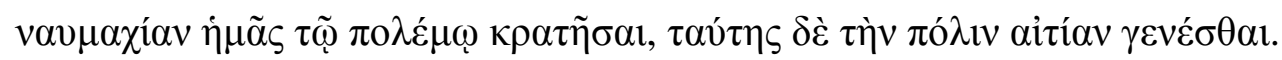

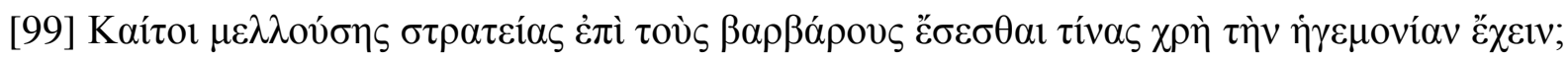

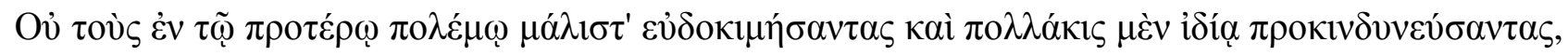

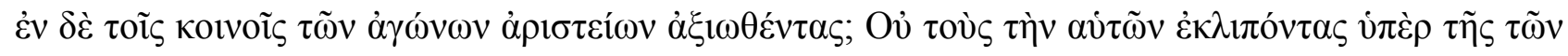

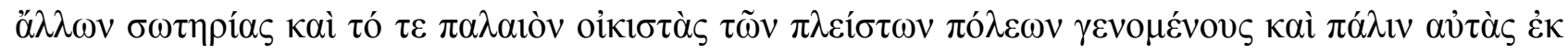

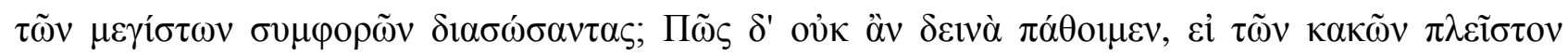




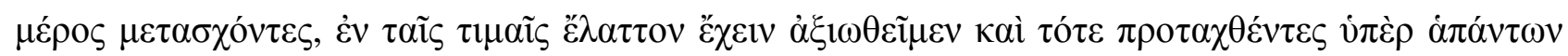

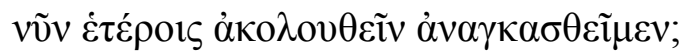

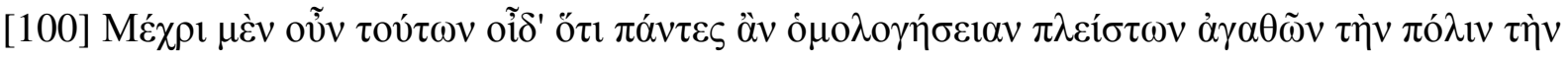

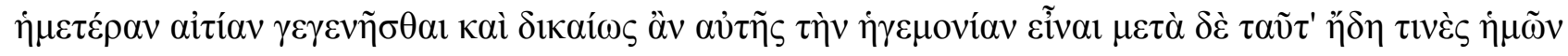

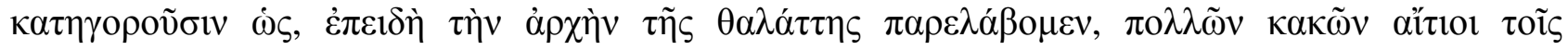
"E

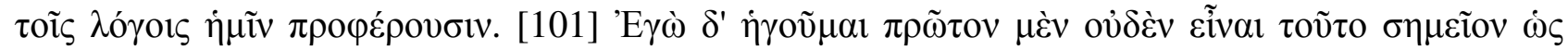

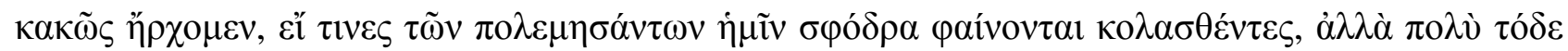

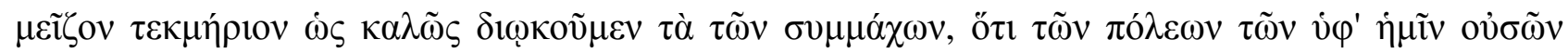

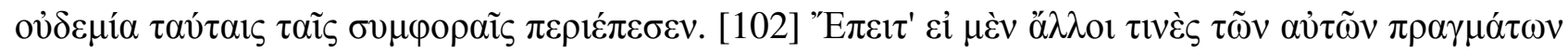

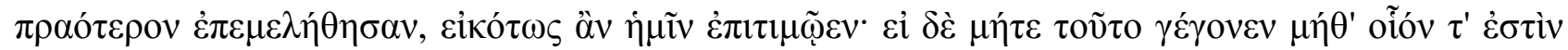

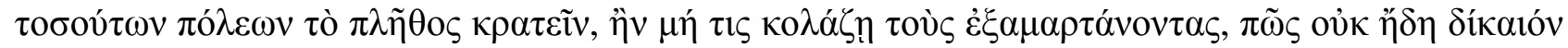

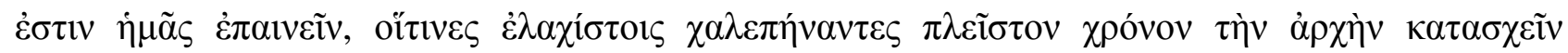

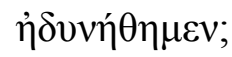

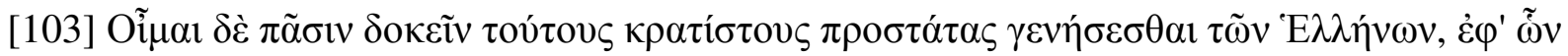

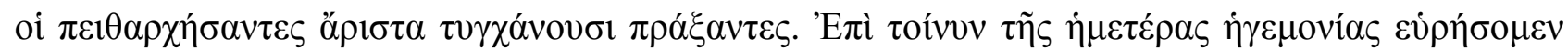

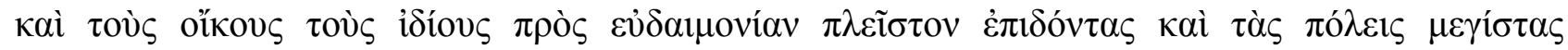

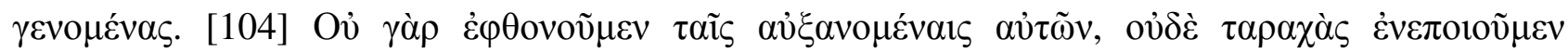

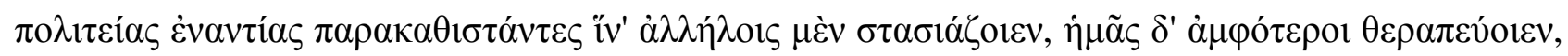

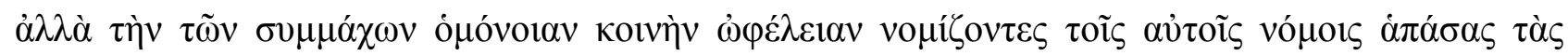

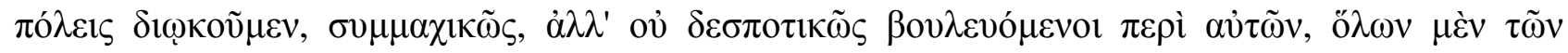

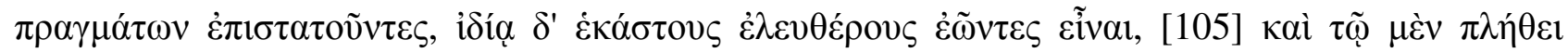

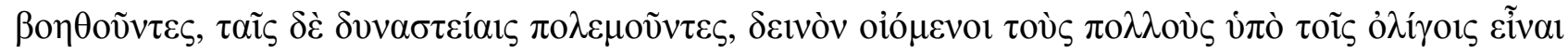

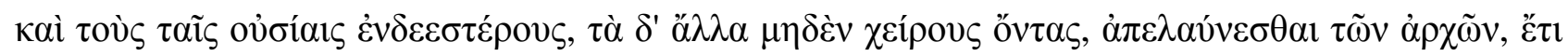

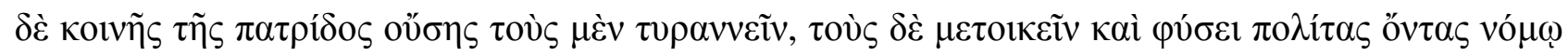




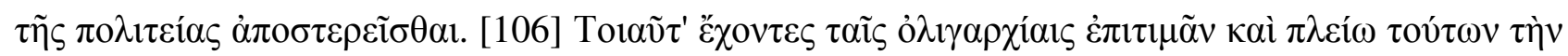

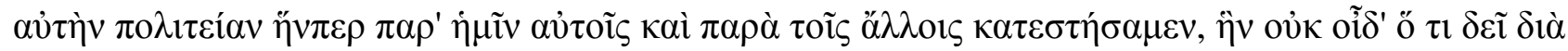

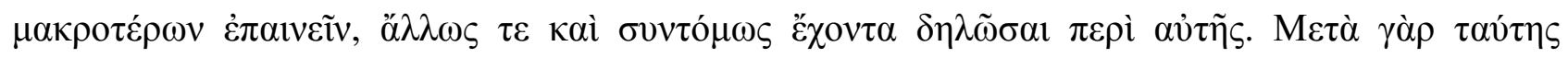

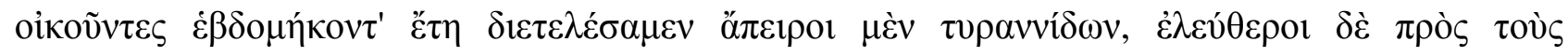

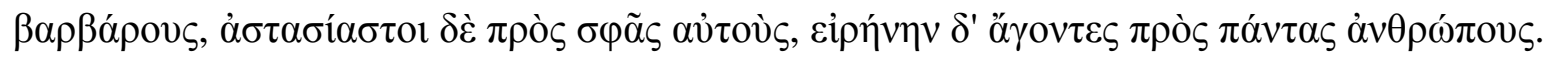

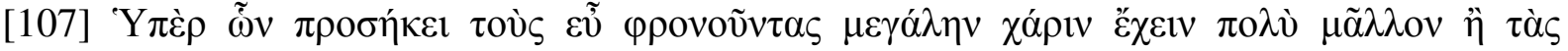

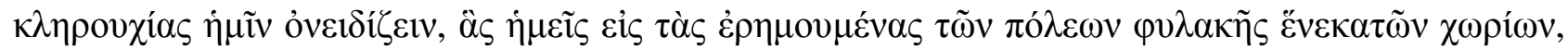

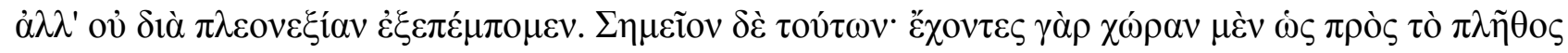

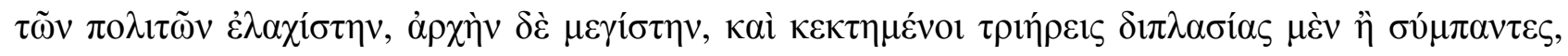

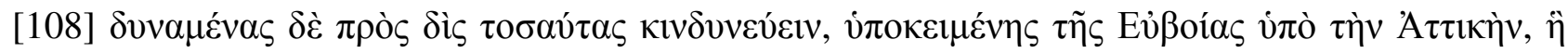

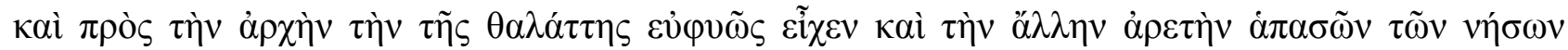

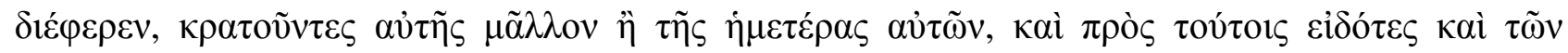

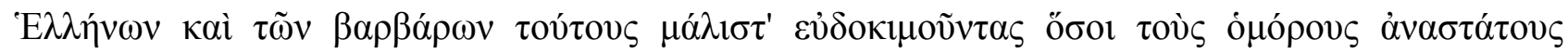

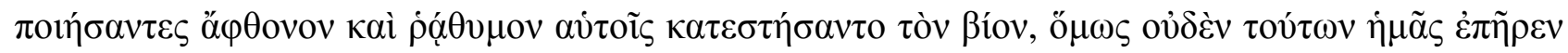

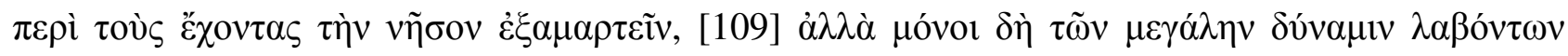

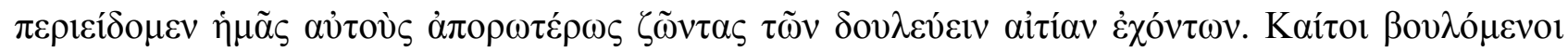

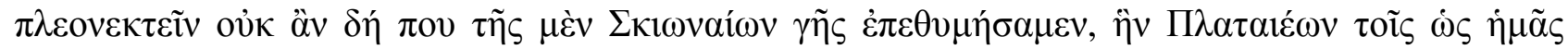

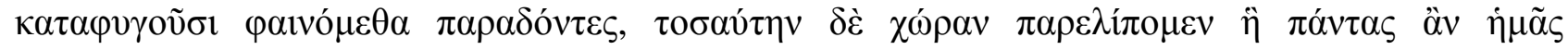

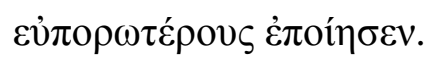

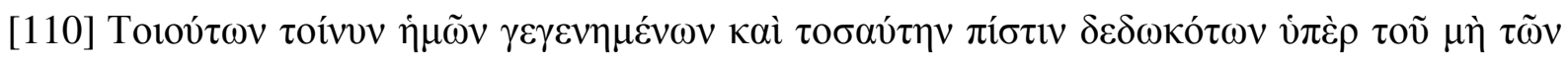

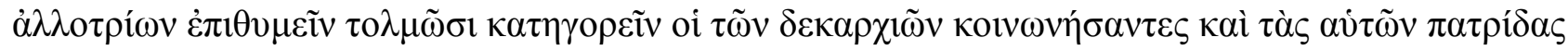

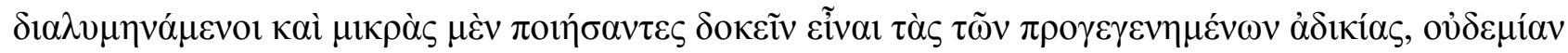

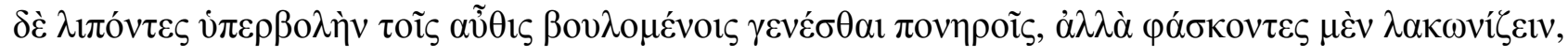

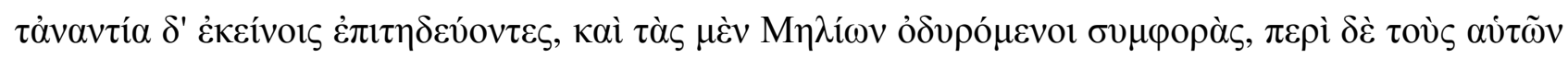

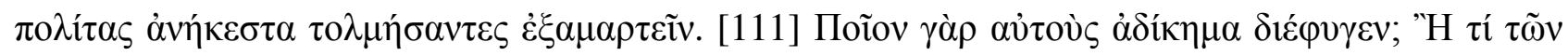




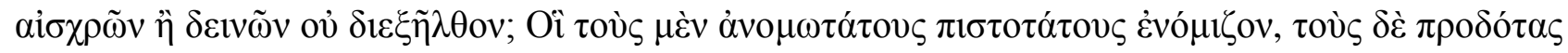


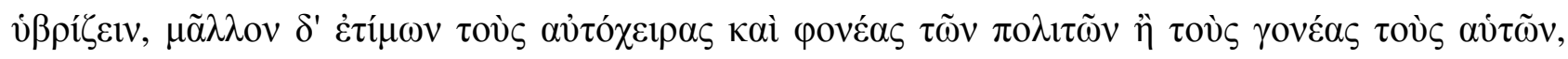

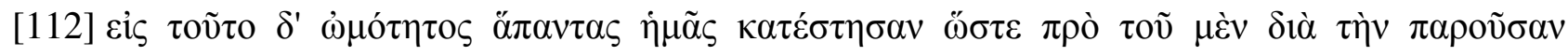

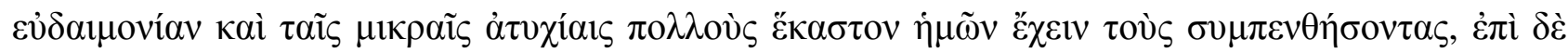

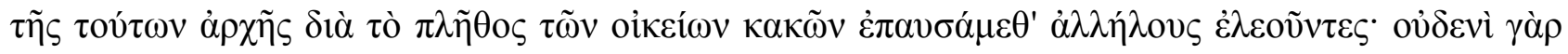

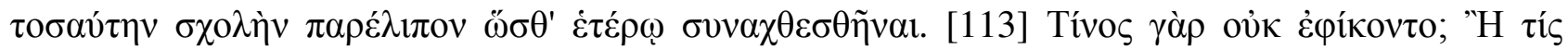

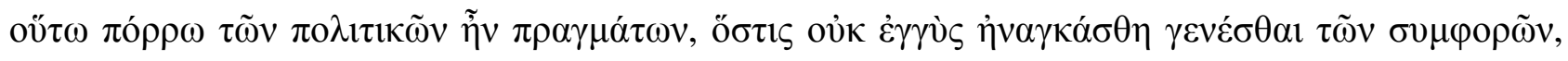

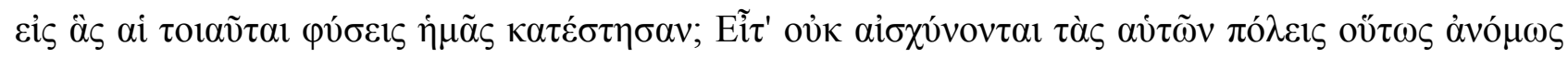

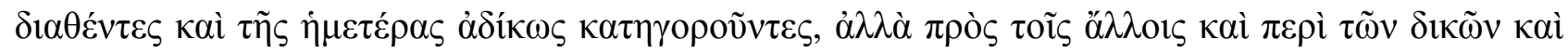

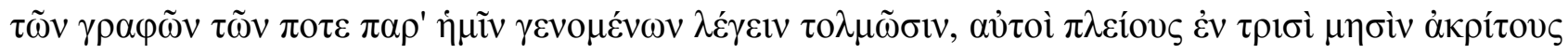

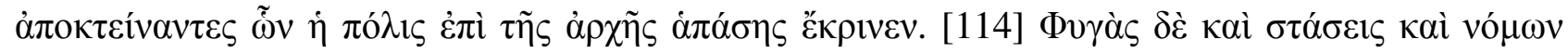

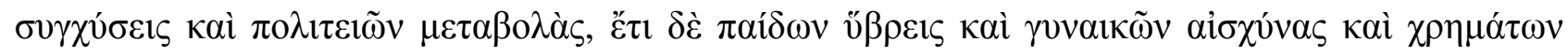

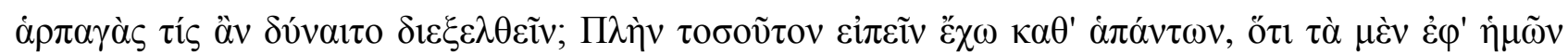

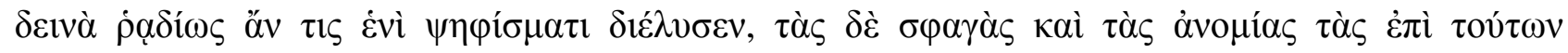

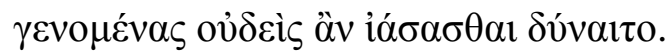

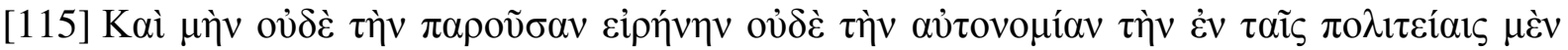

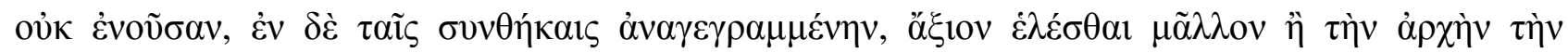

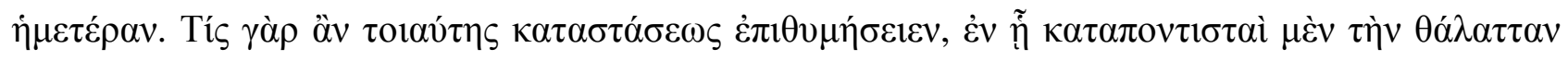

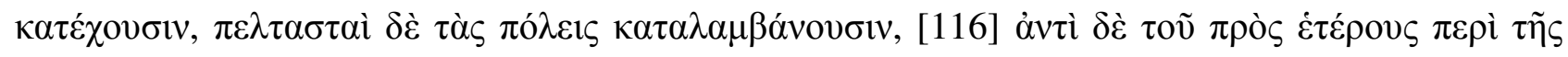

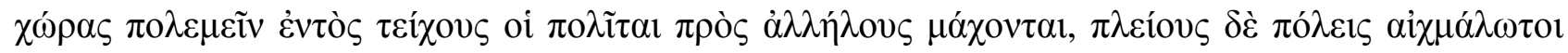

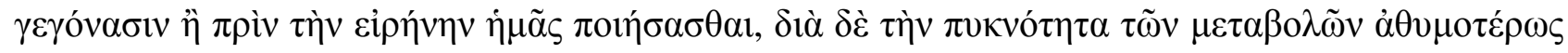

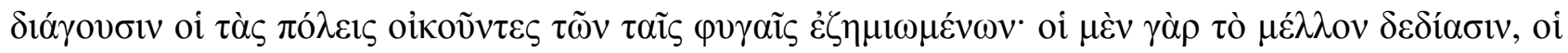

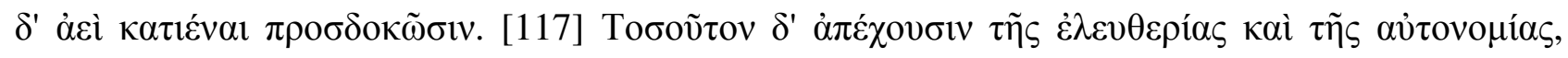

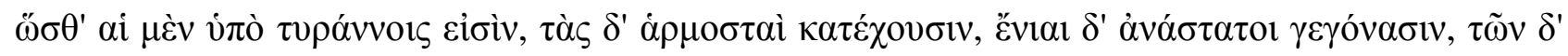




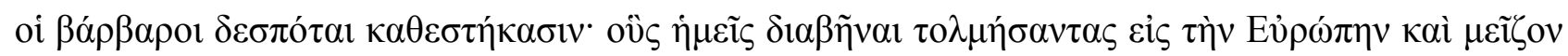

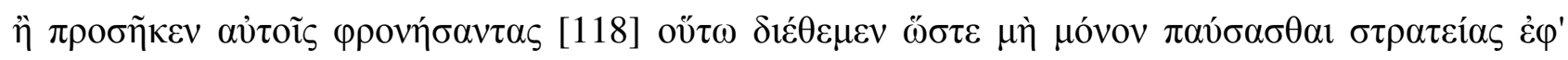

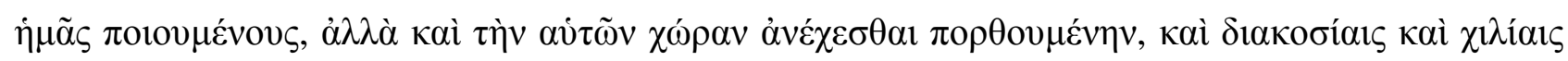

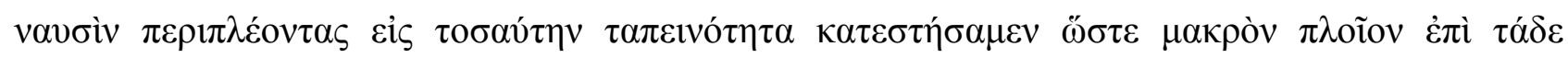

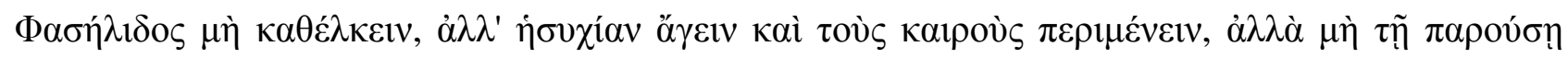

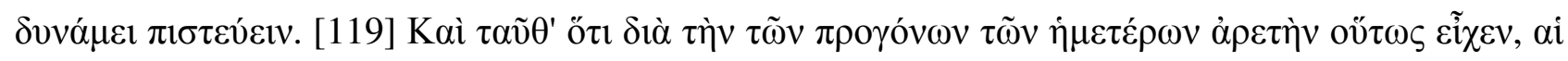

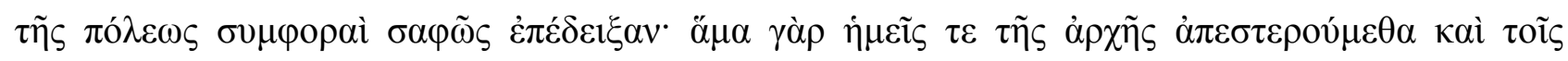

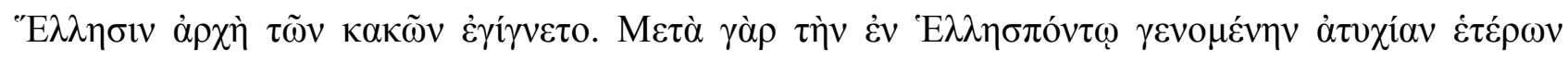

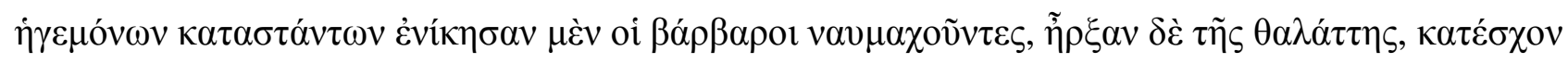

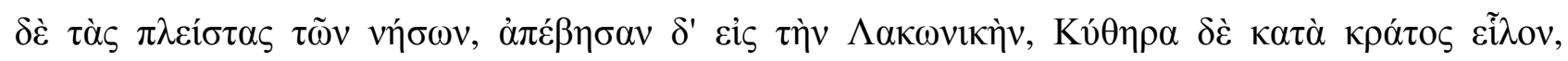

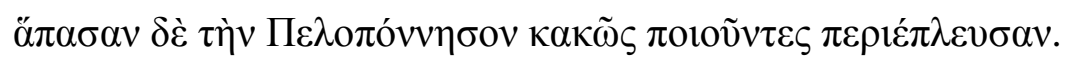

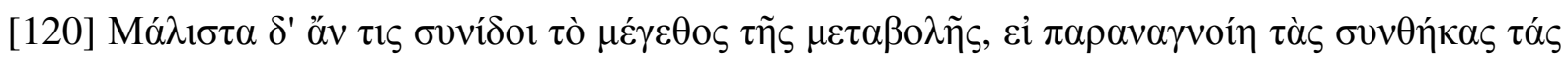

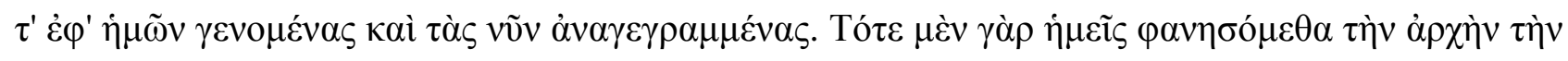

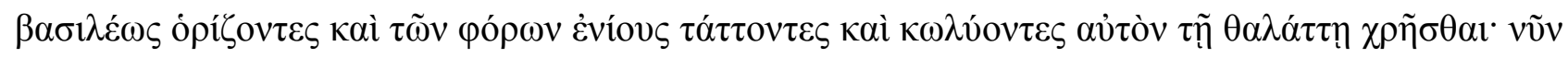

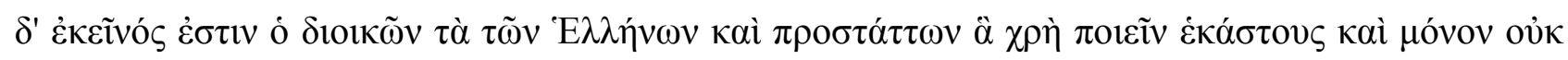

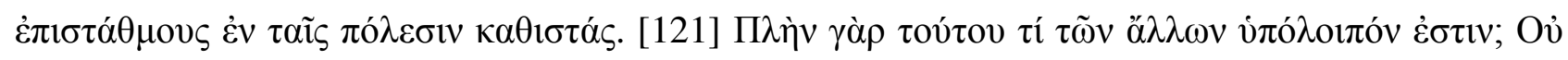

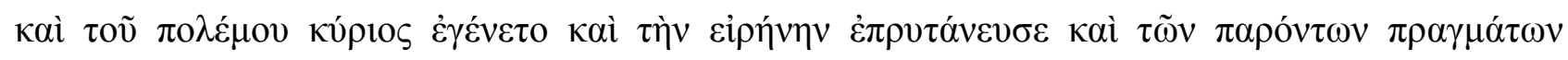

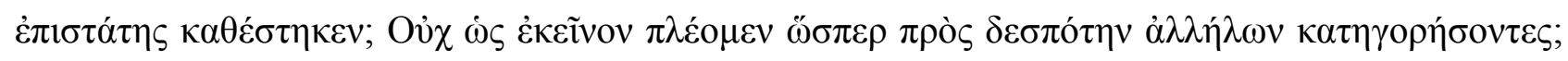

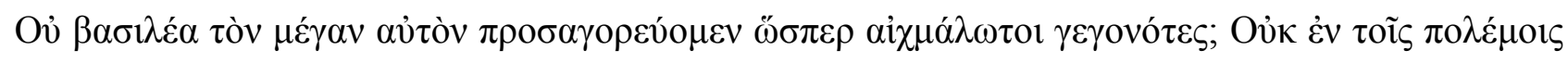

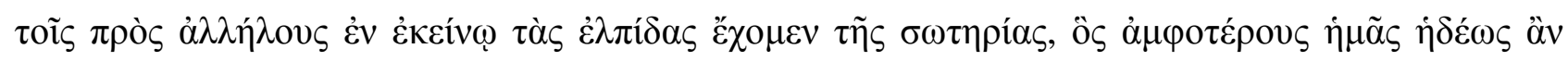

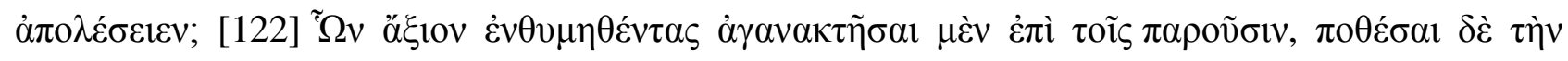

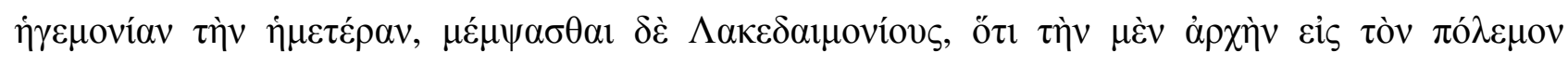

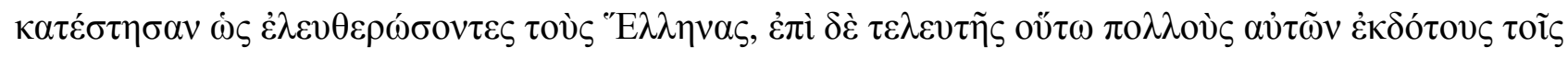

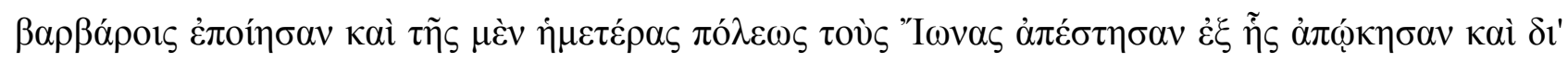

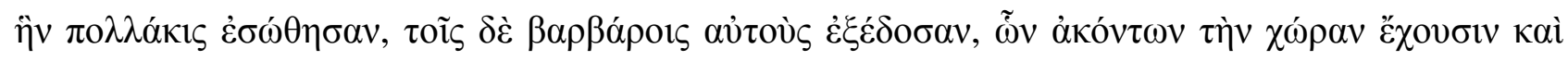




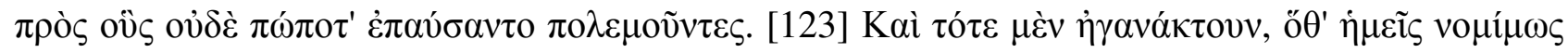

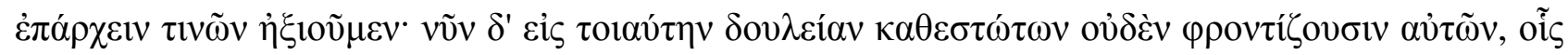

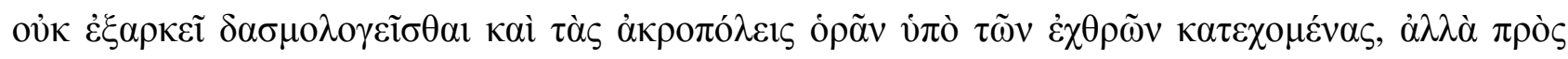

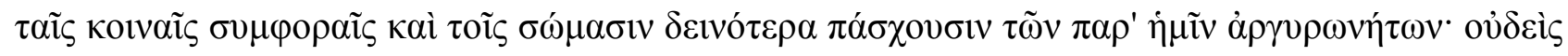

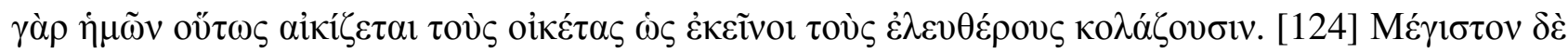

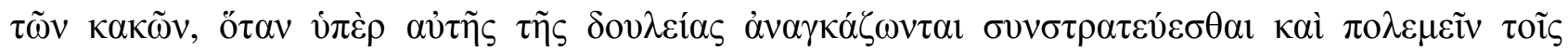

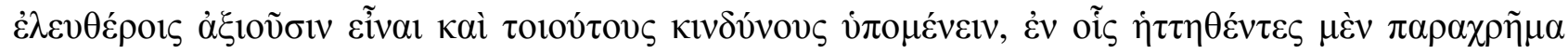

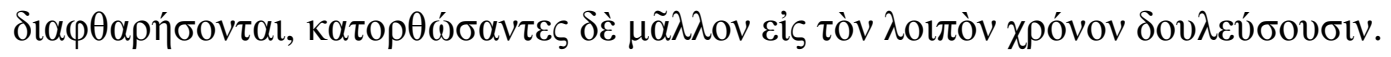

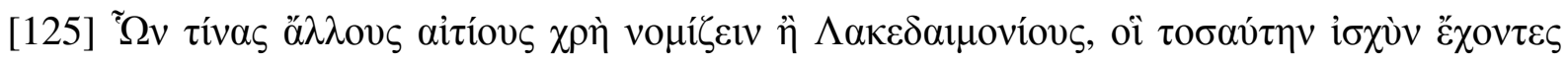

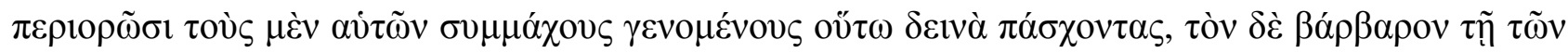

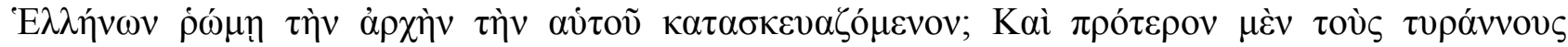

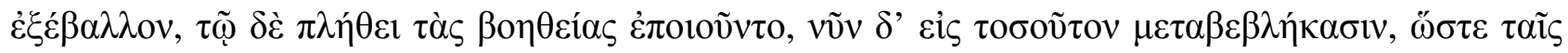

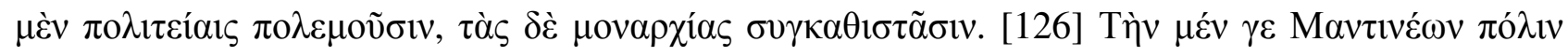

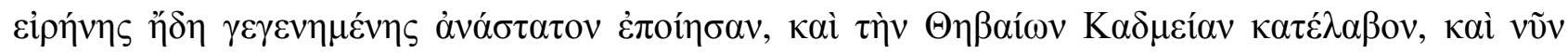

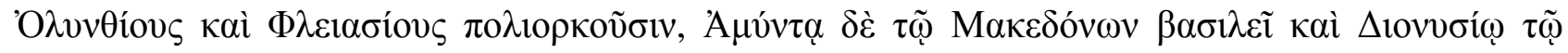

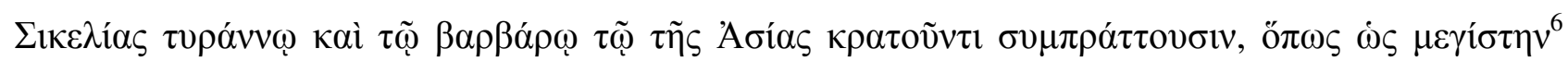

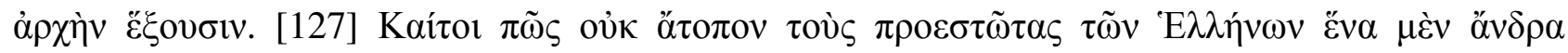

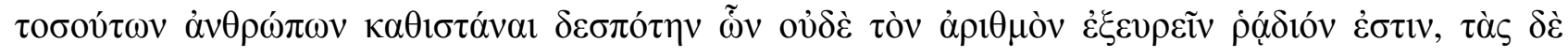

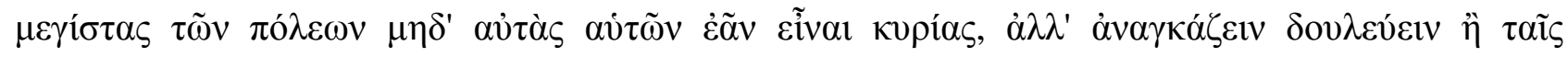

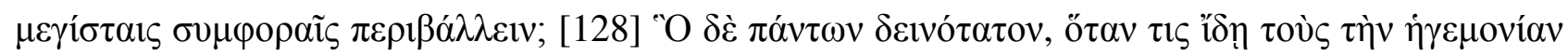

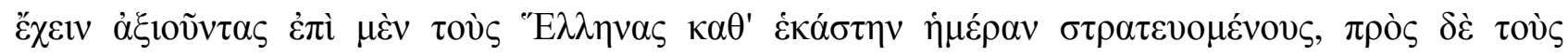

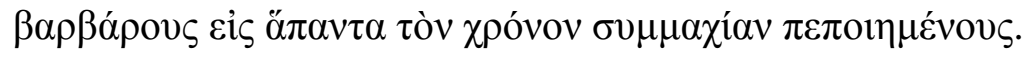

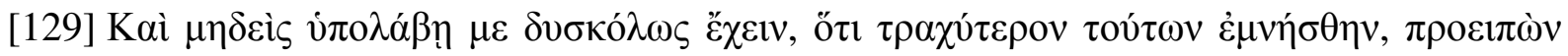

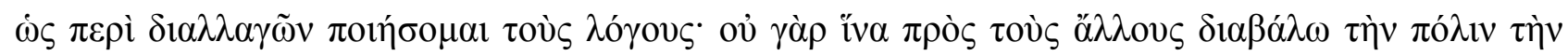

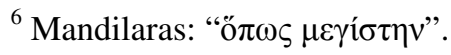




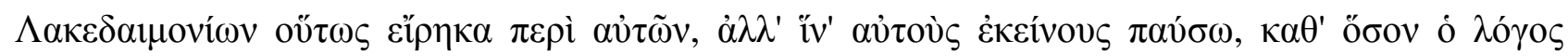

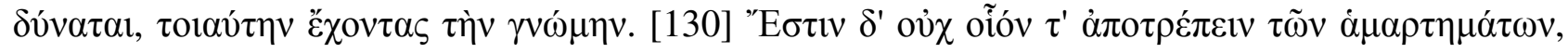

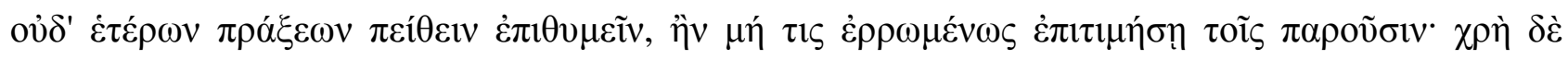

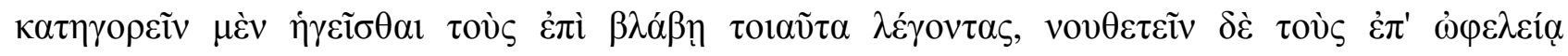

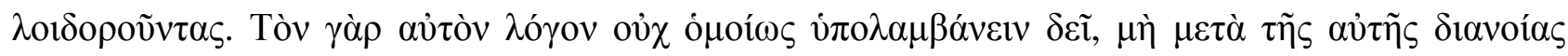

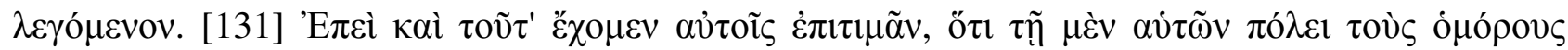

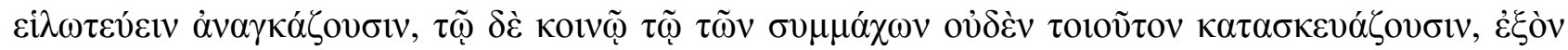

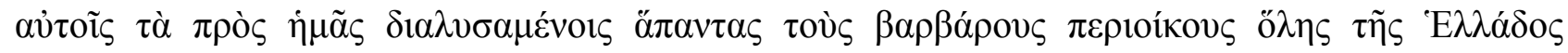

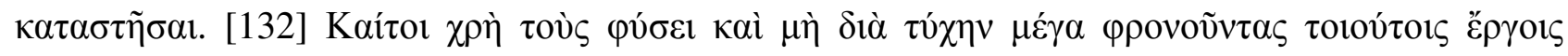

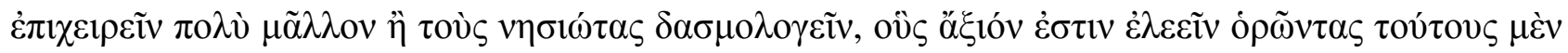

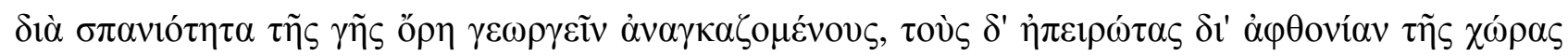

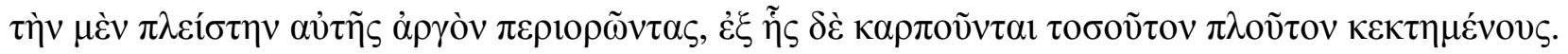

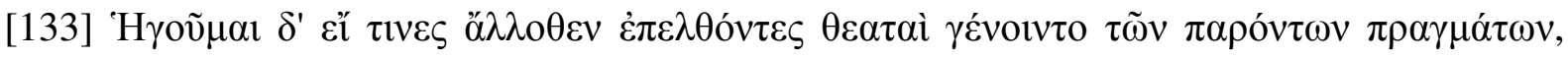

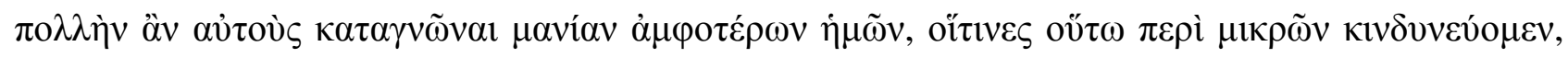

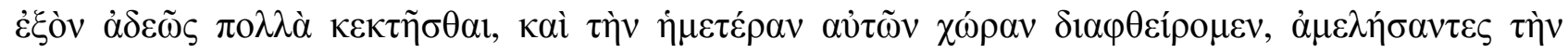

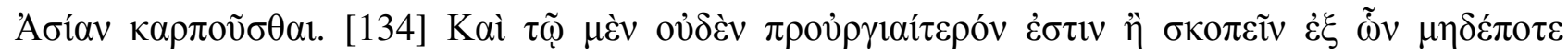

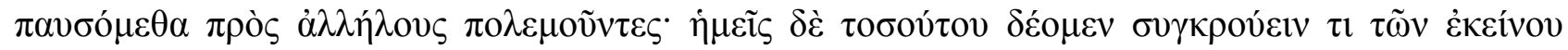

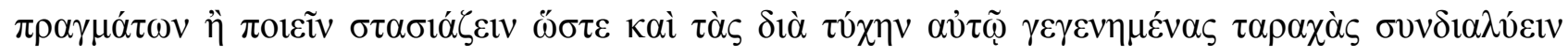

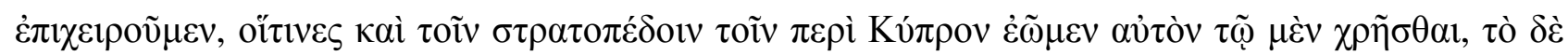

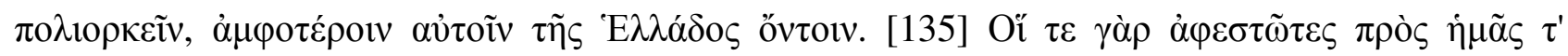

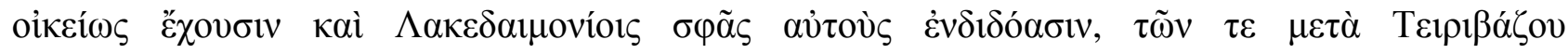

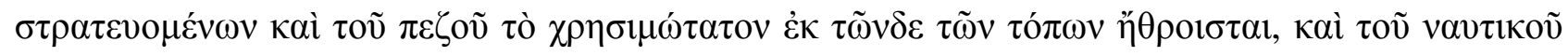

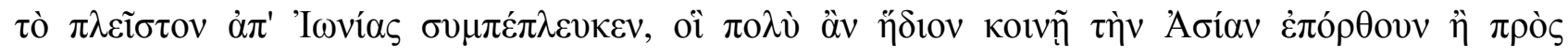

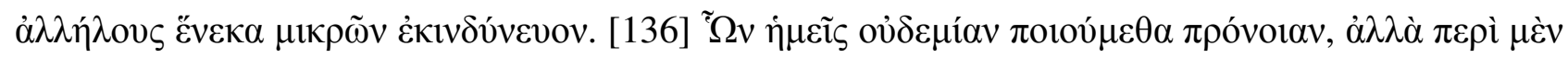

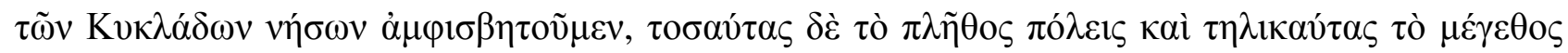




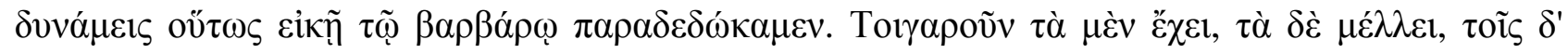

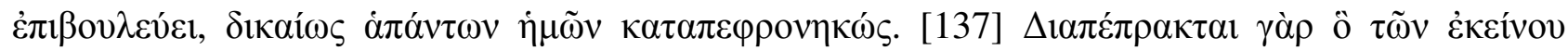

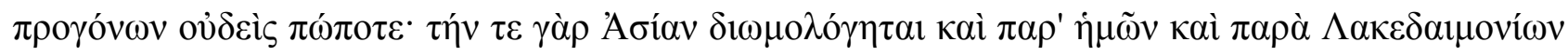

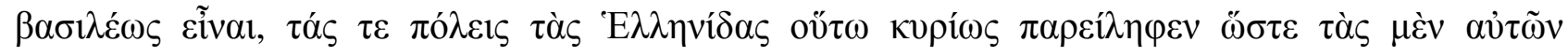

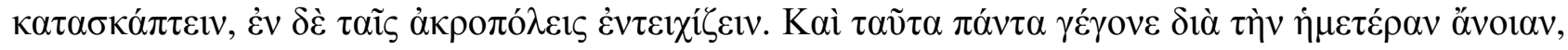

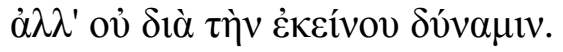

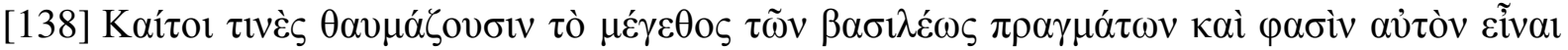

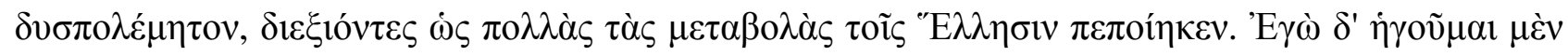

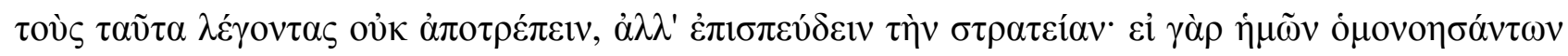

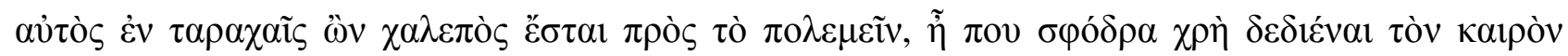

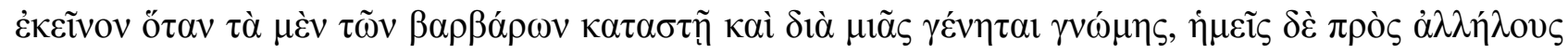

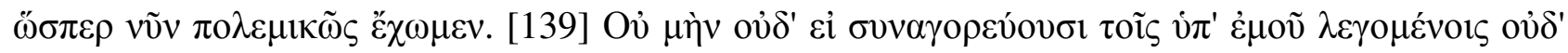

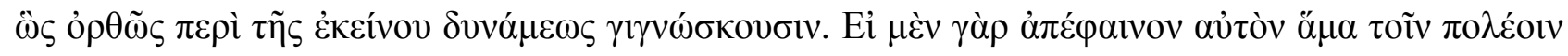

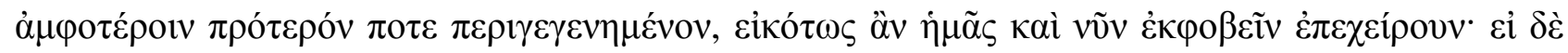

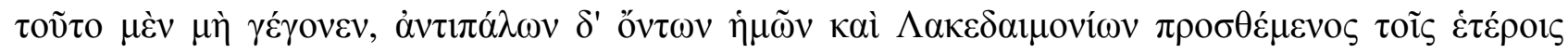

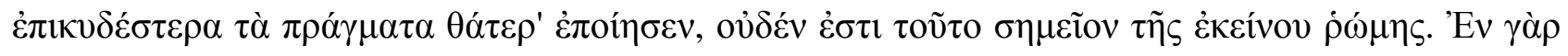

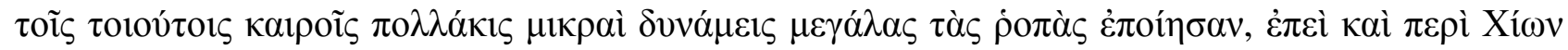

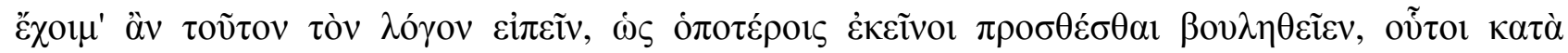
$\theta \alpha \dot{\lambda} \alpha \tau \tau \alpha \nu \kappa \rho \varepsilon i ́ \tau \tau o \cup \varsigma \tilde{\eta} \sigma \alpha \nu$.

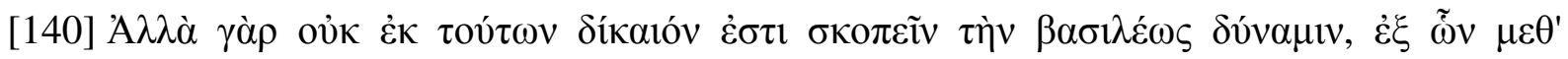

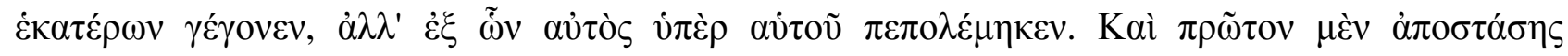

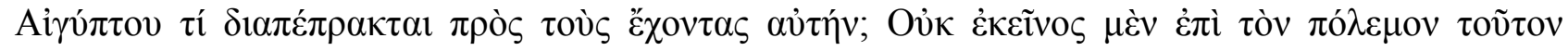

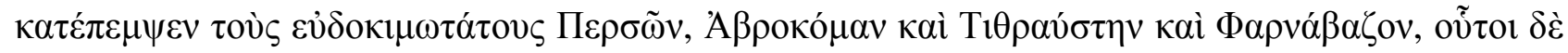

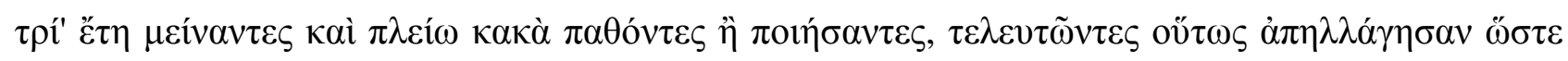

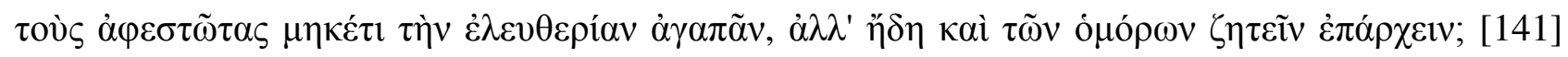




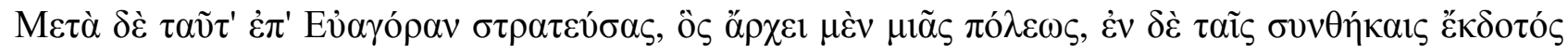

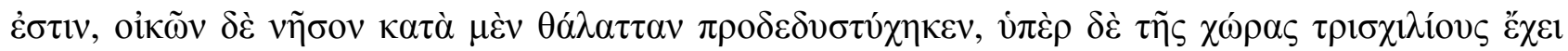

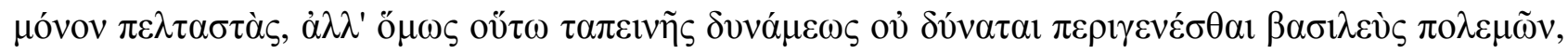

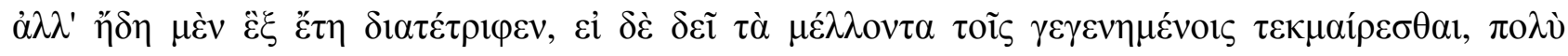

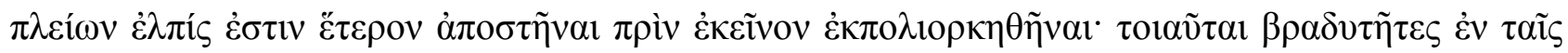

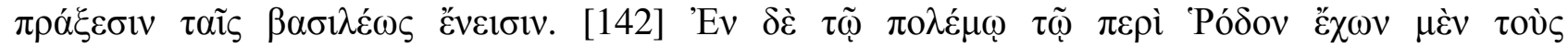

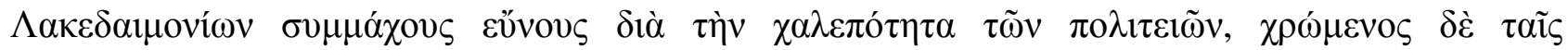

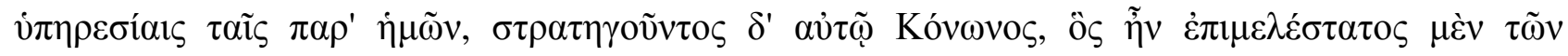

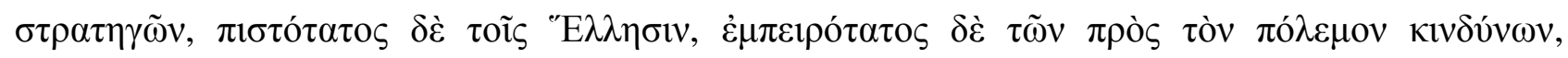

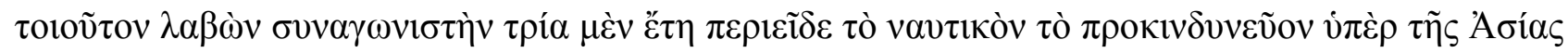

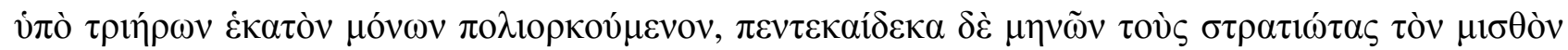

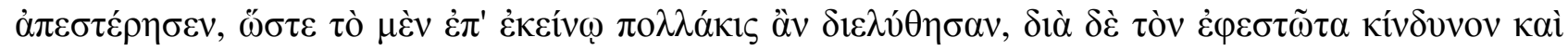

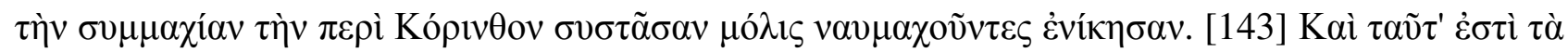

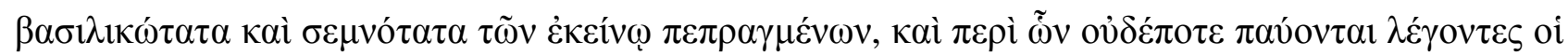

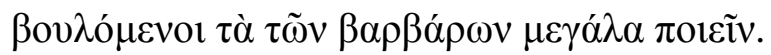

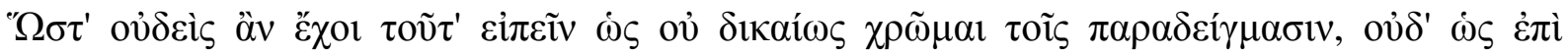

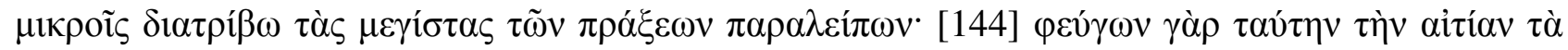

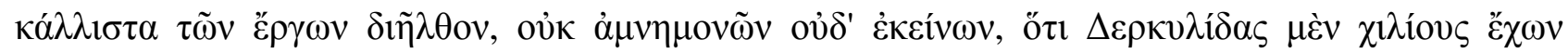

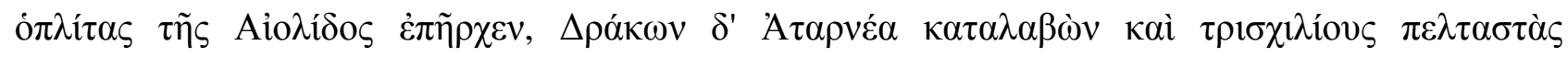

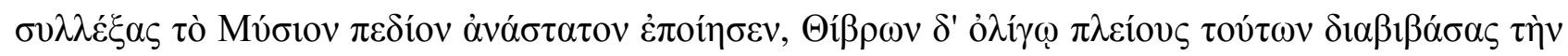

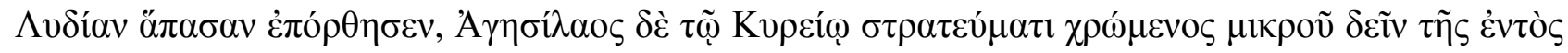

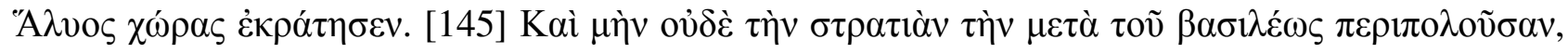

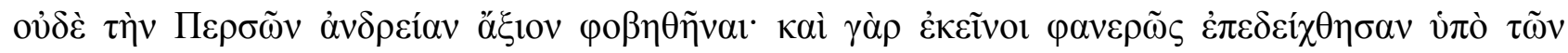

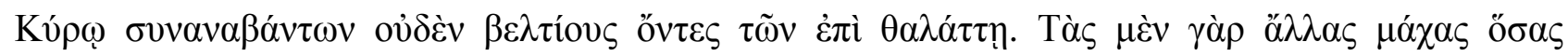

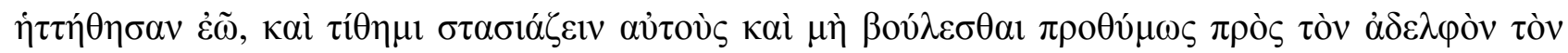




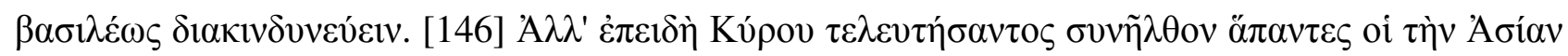

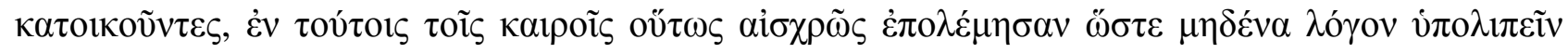

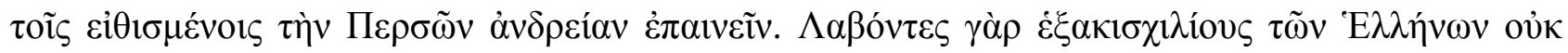

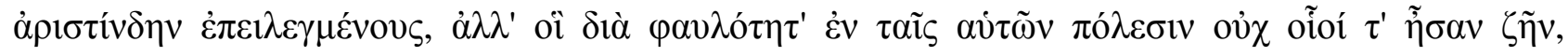

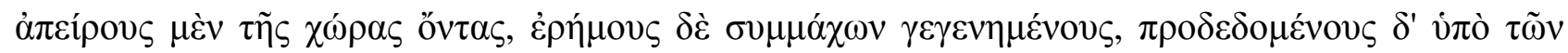

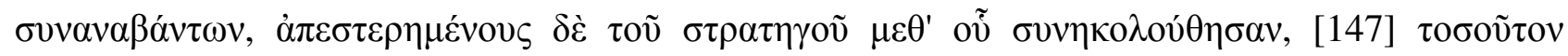

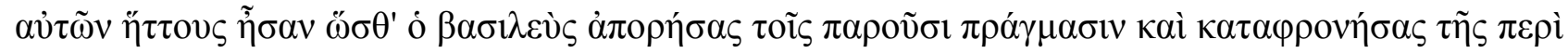

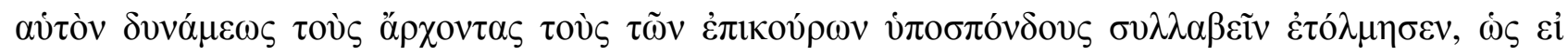

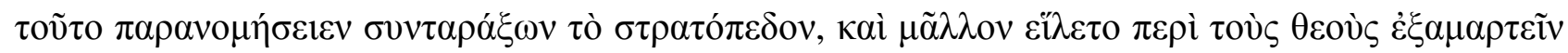

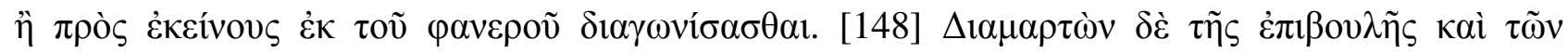

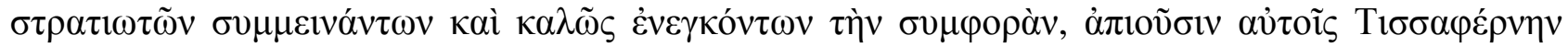

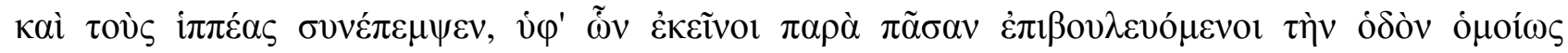

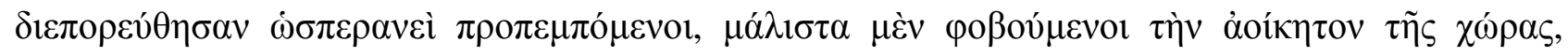

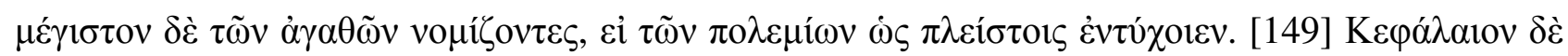

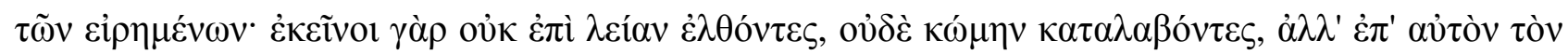

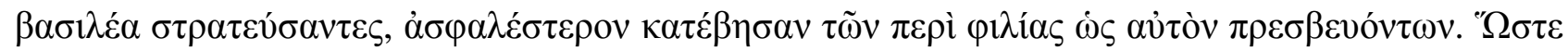

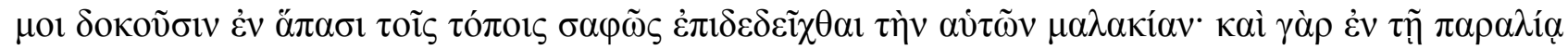

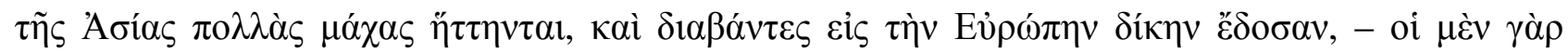

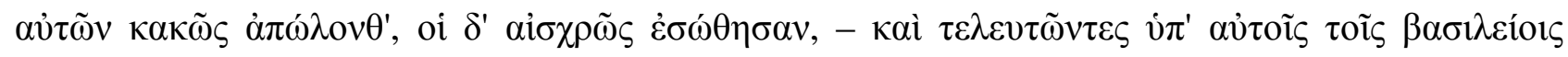

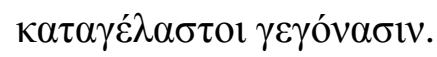

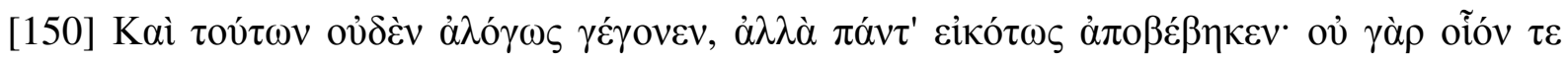

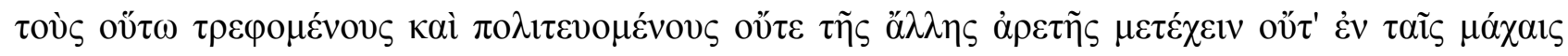

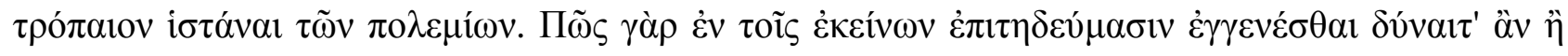

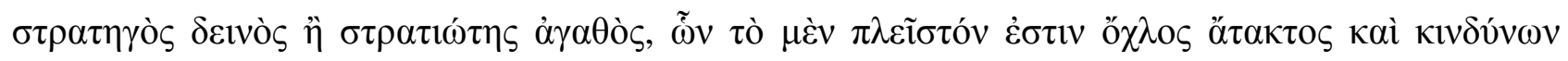

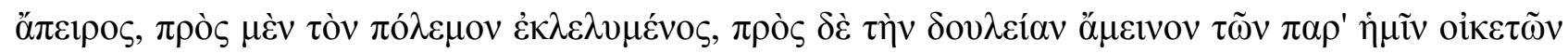




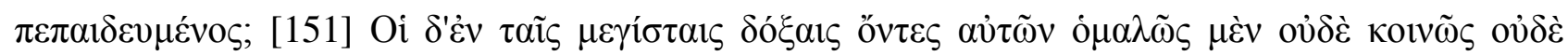

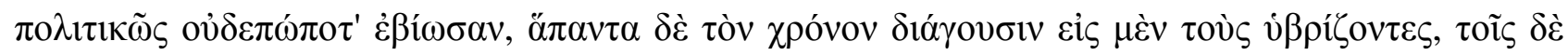

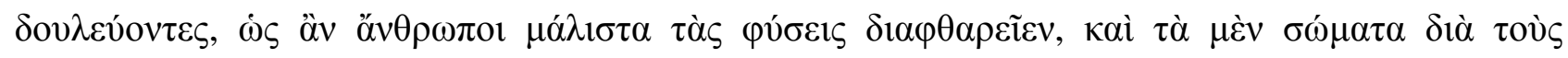

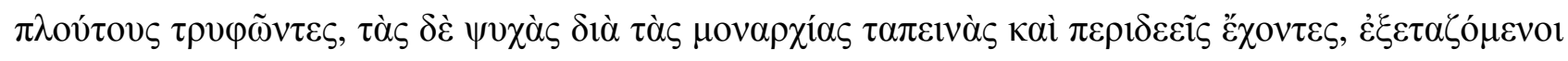

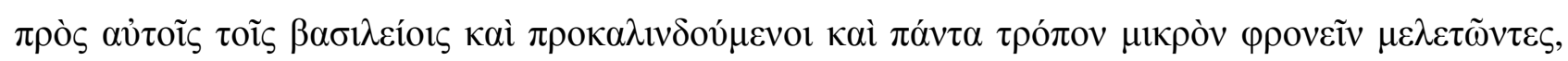

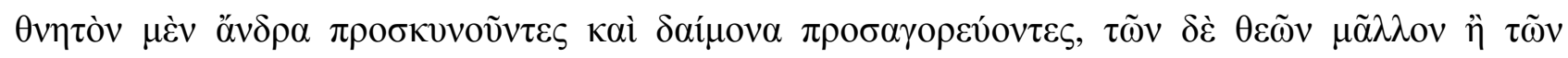

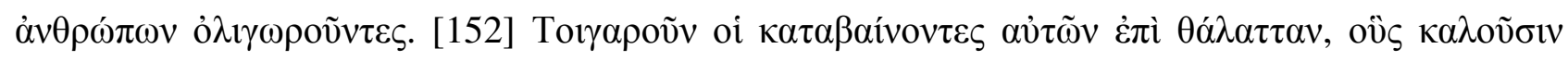

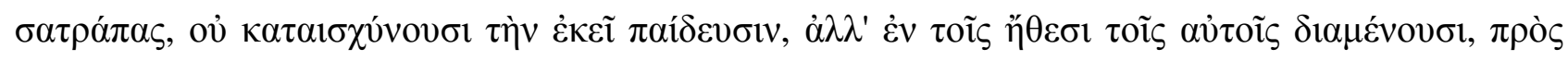

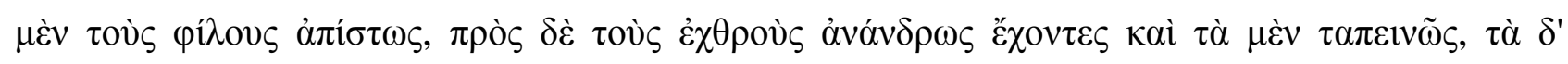

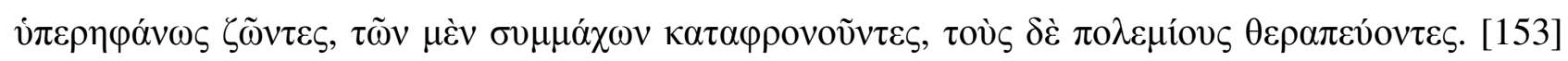

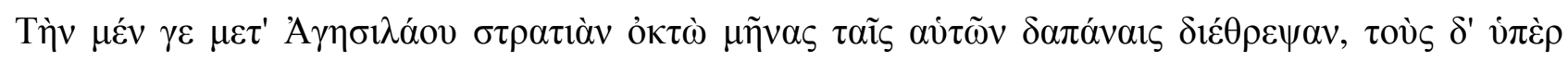

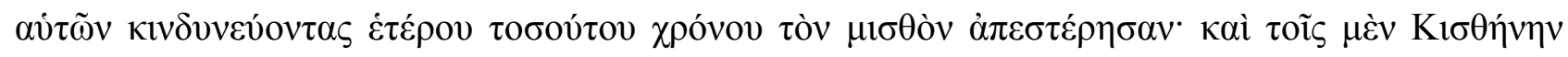

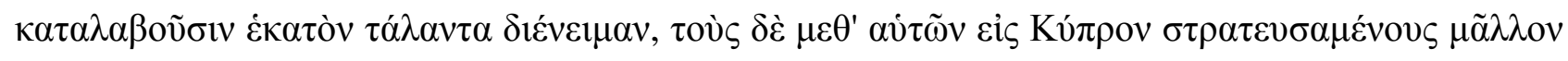

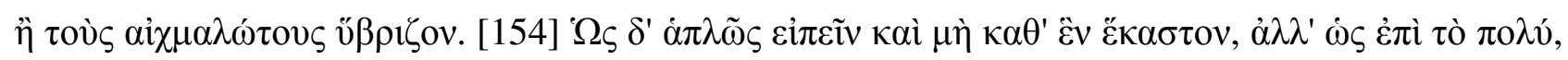

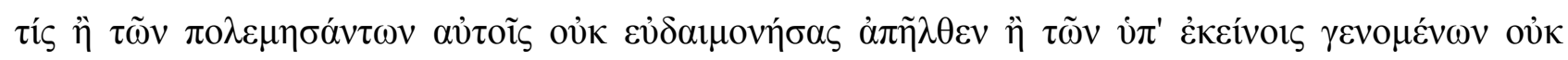

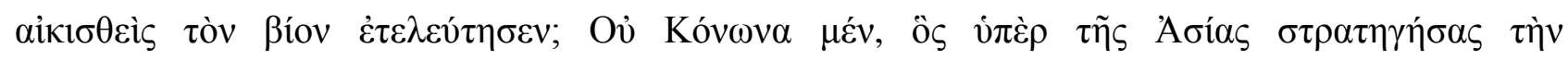

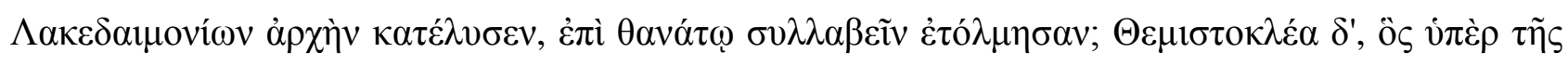

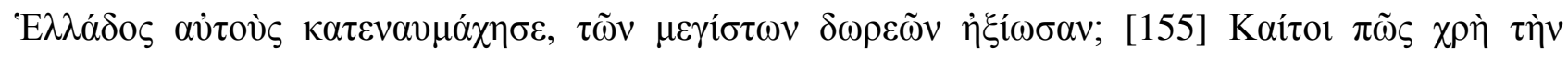

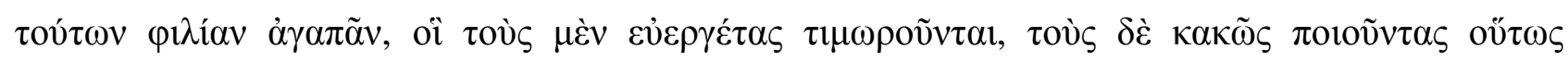

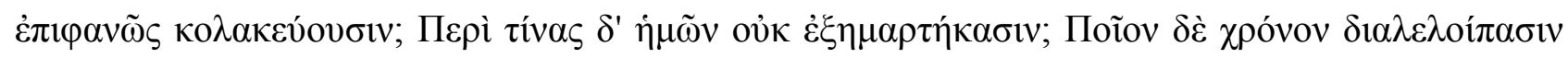

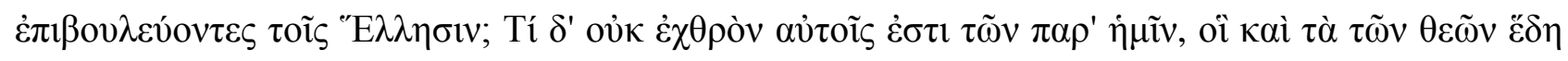

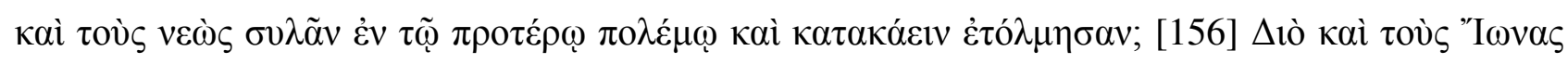

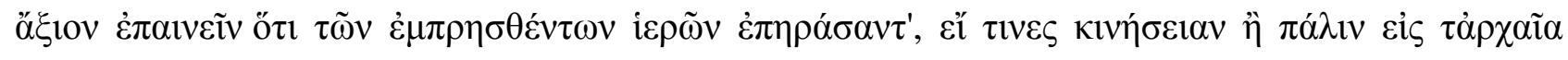

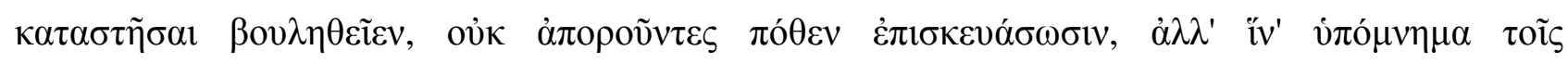

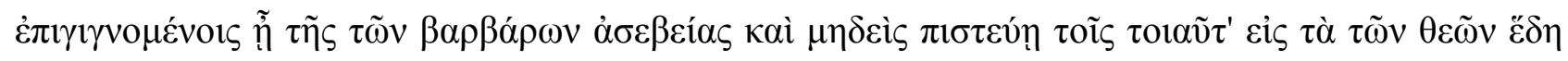




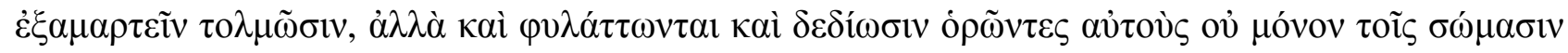

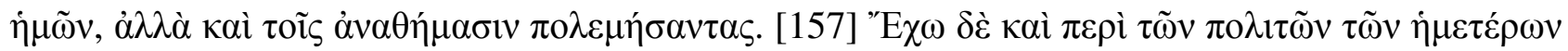

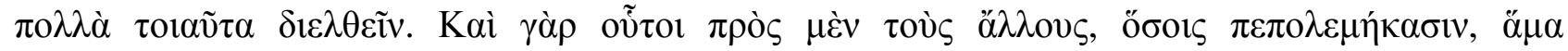

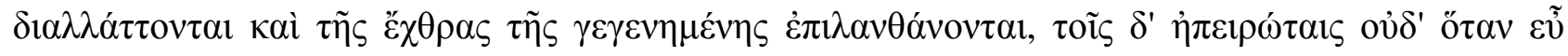

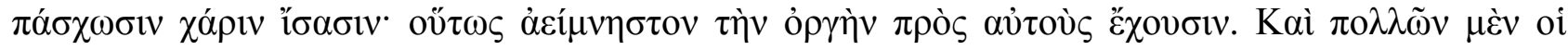

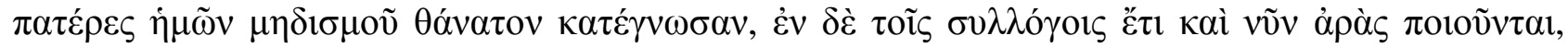

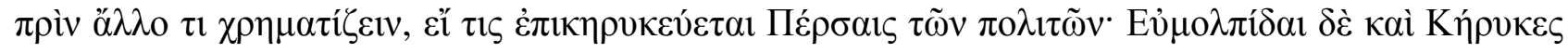

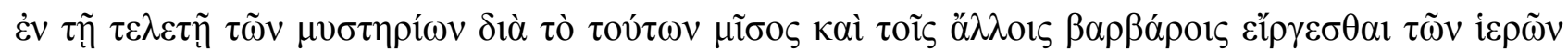

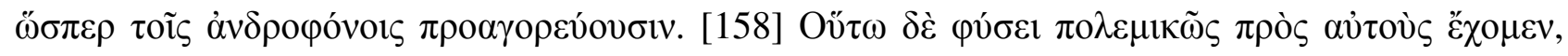

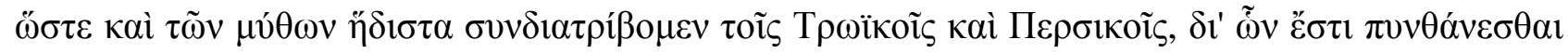

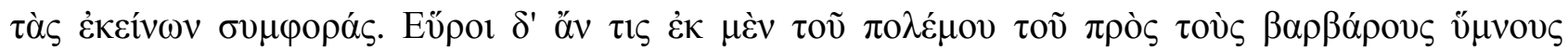

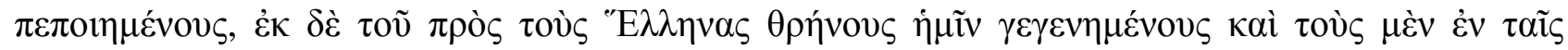

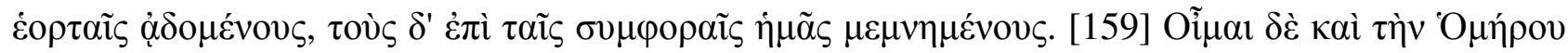

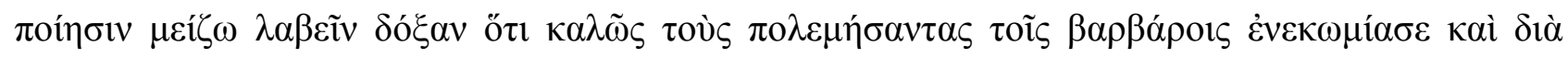

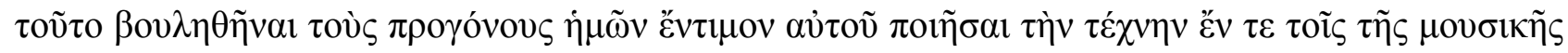

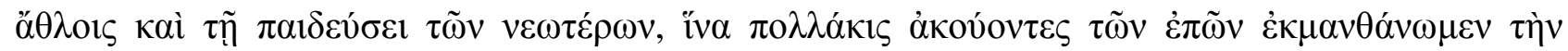

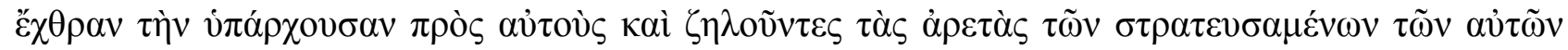

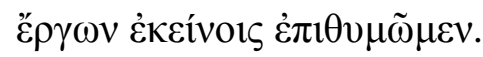

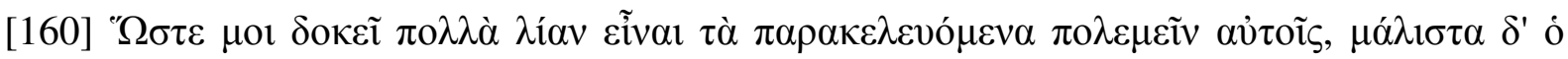

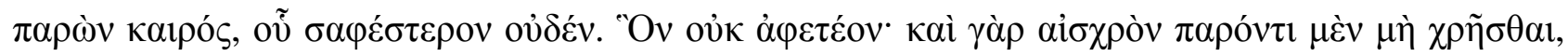

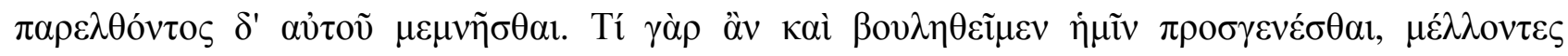

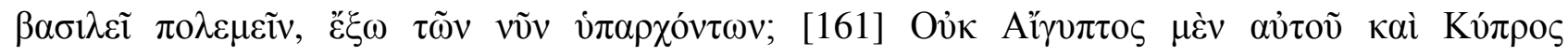

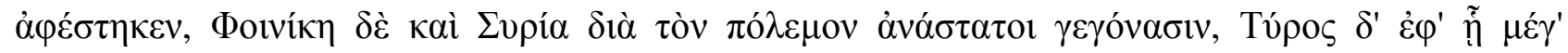

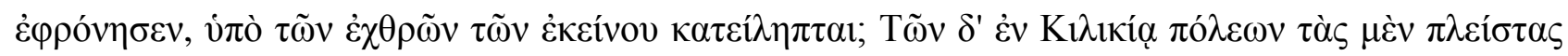

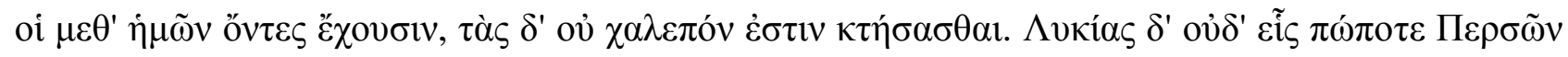




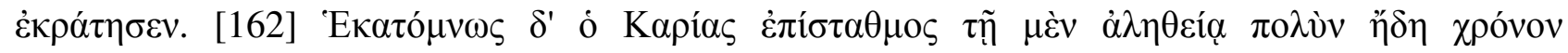

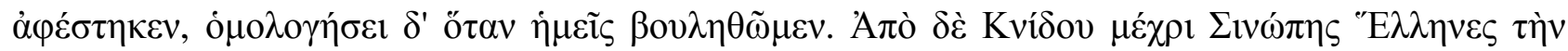

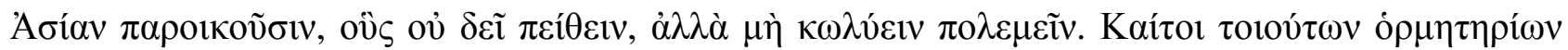

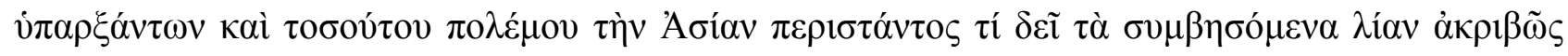

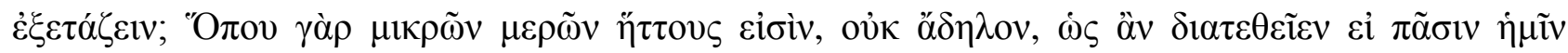

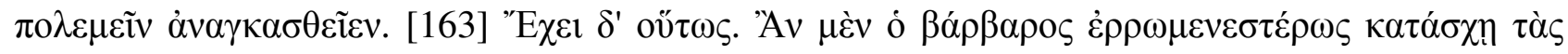

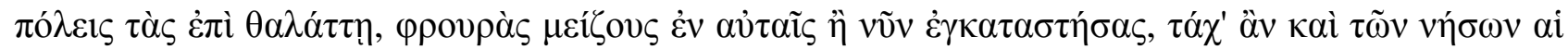

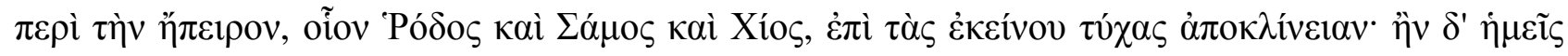

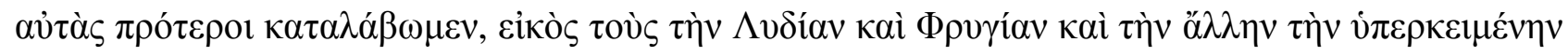

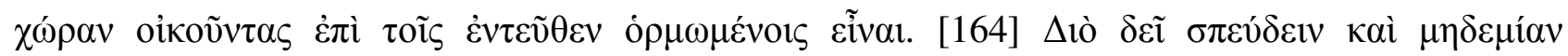

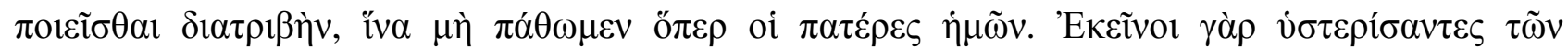

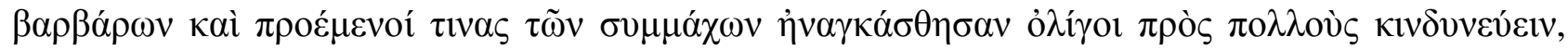

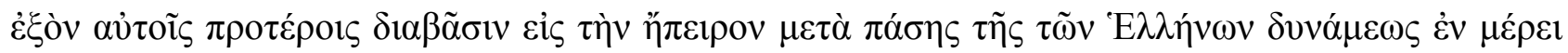

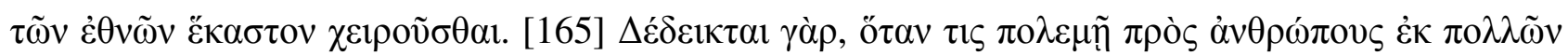

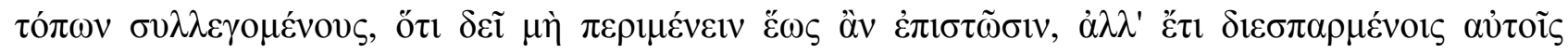

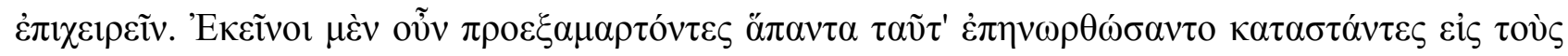

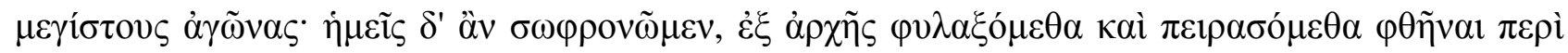

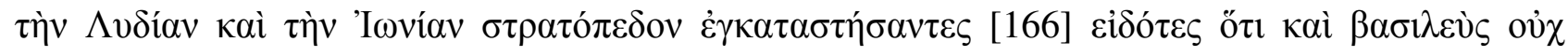

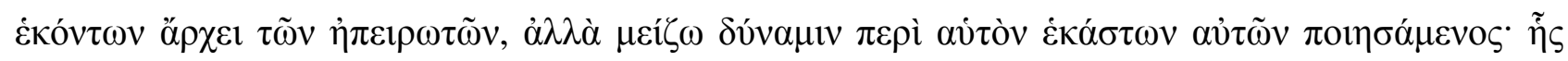

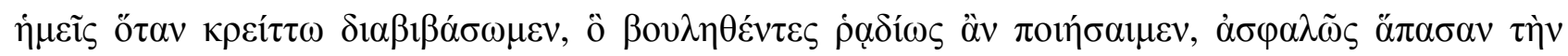

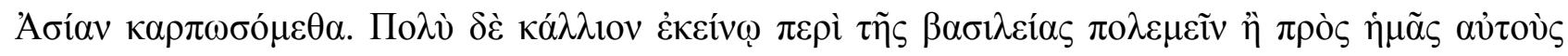

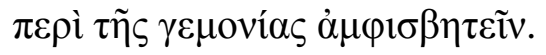

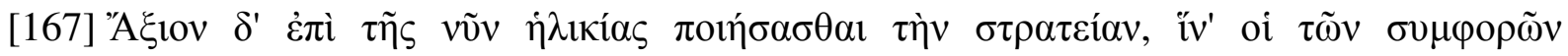

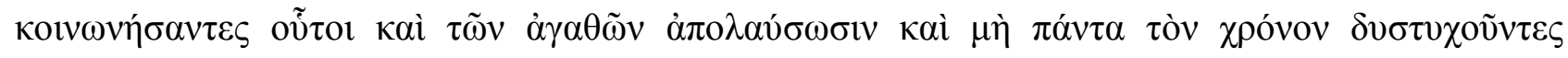

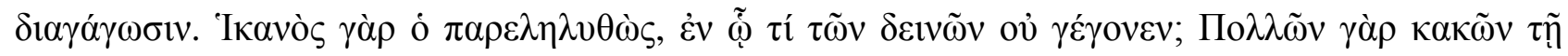




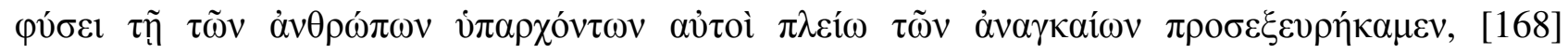

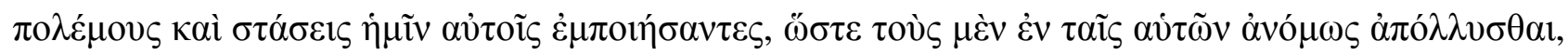

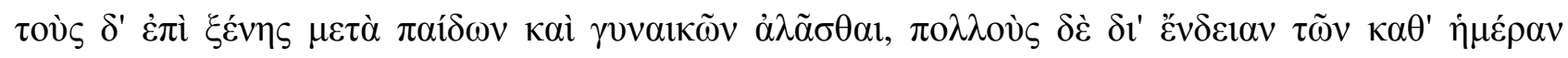

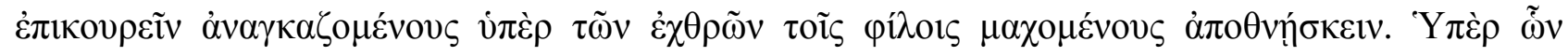

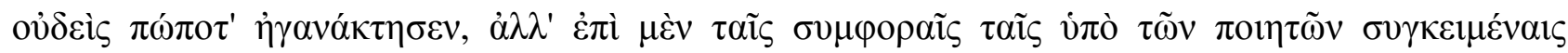

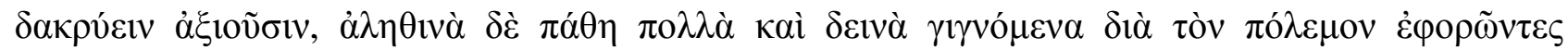

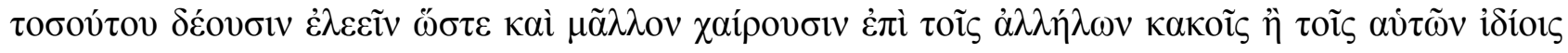

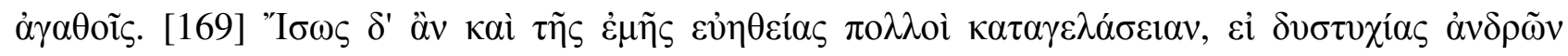

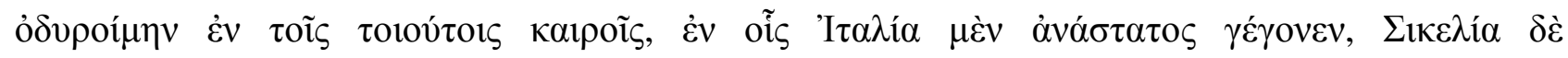

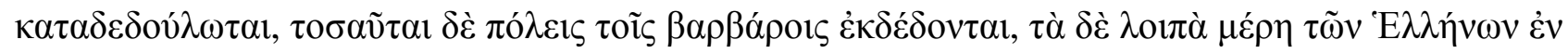

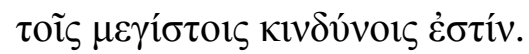

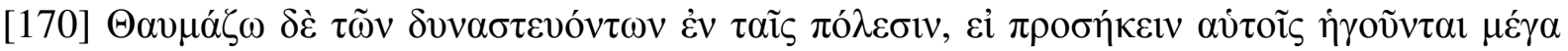

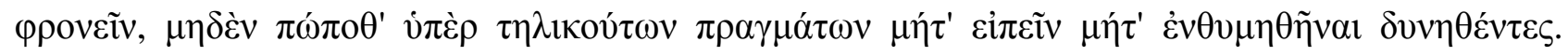

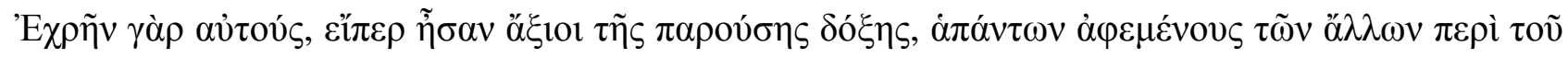

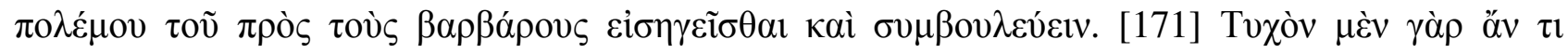

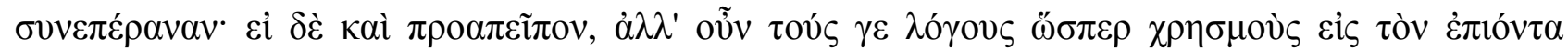

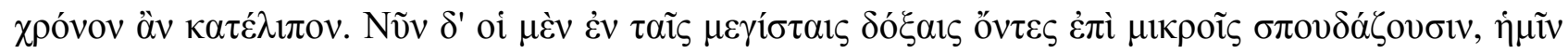

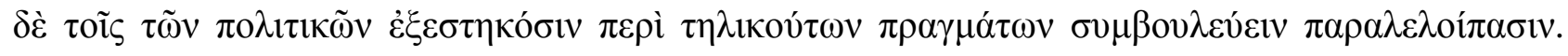

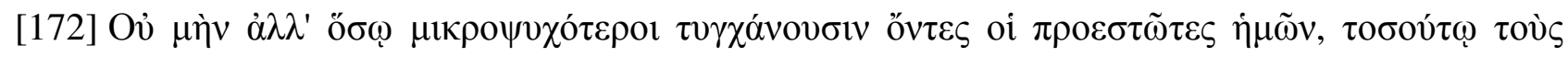

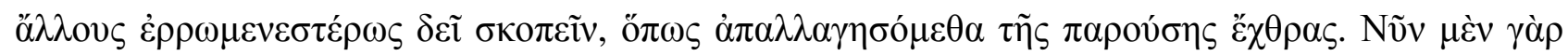

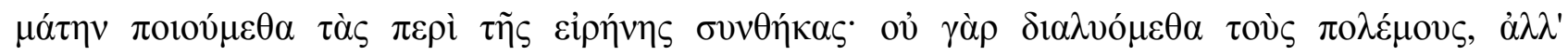

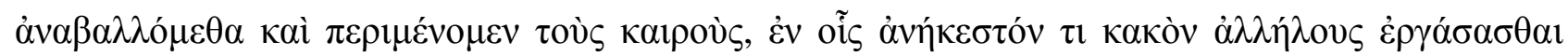
$\delta v \vee \eta \sigma o ́ \mu \varepsilon \theta \alpha$.

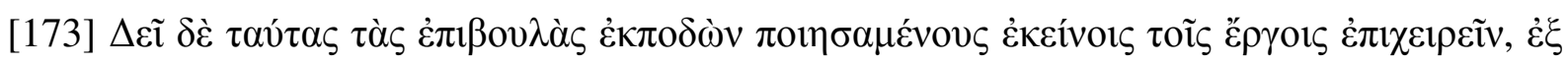

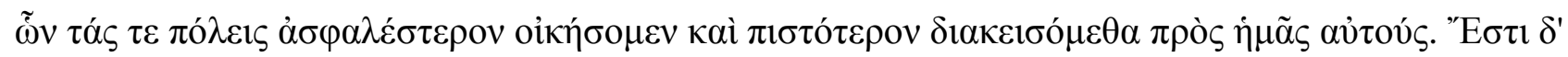




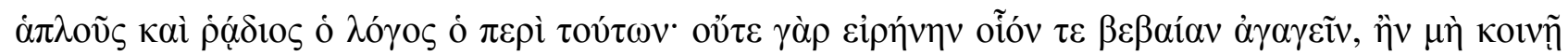

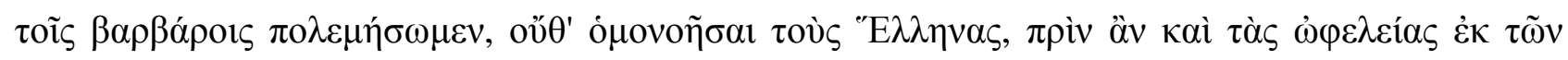

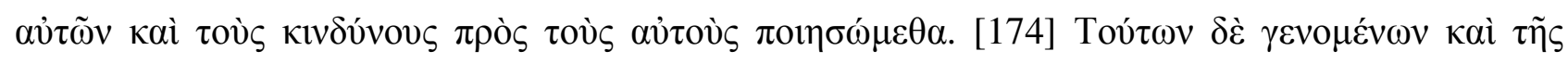

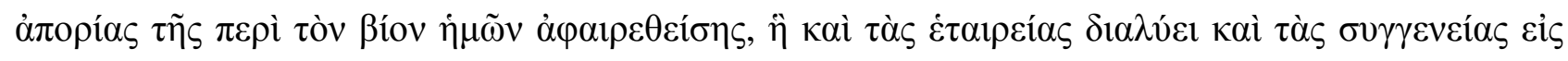

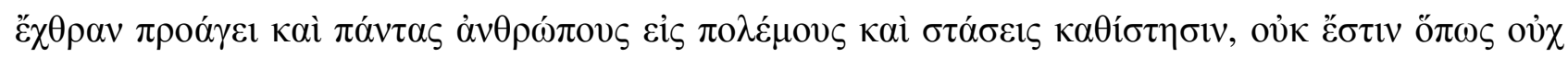

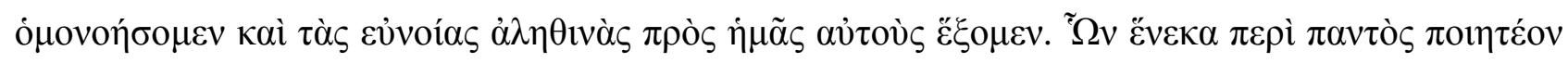

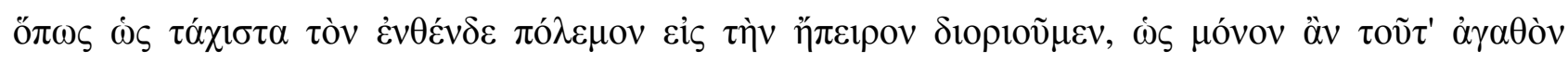

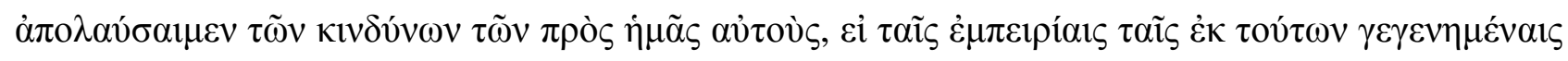

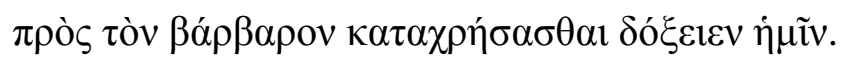

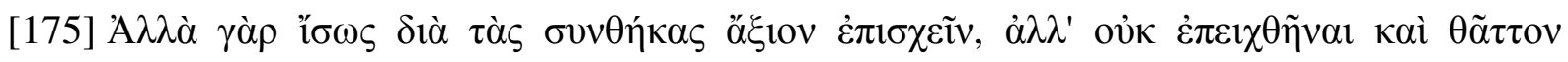

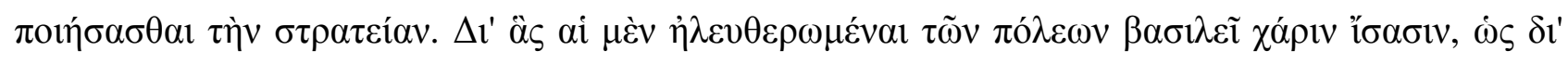

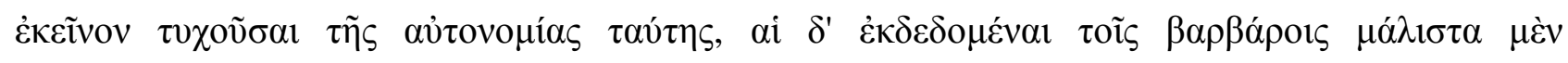

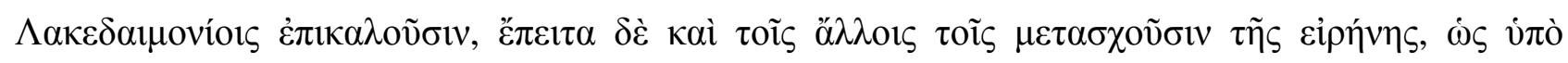

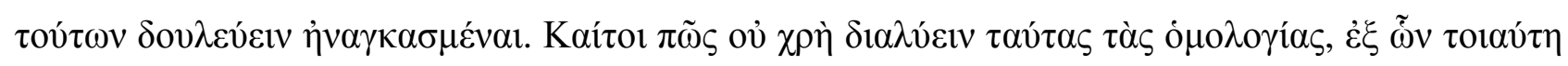

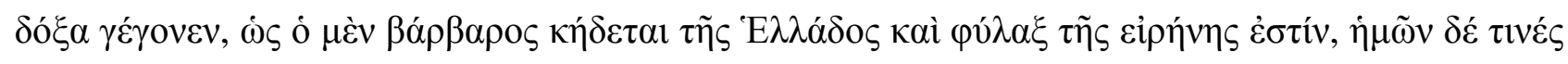

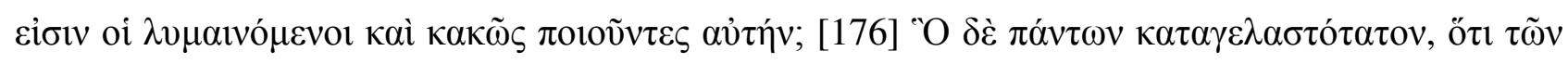

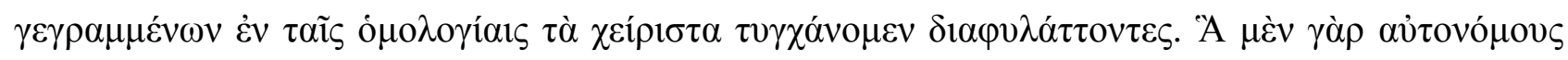

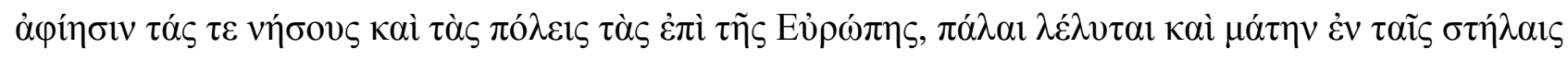

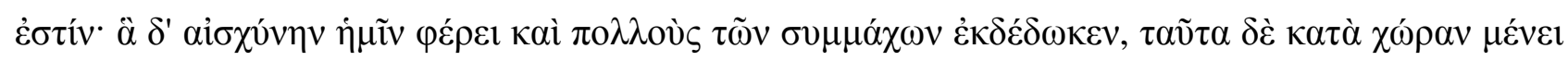

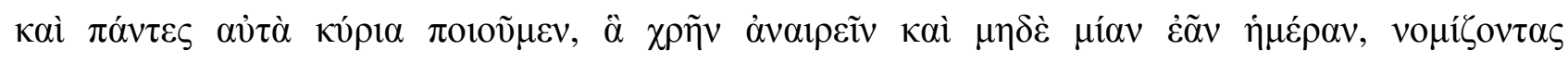

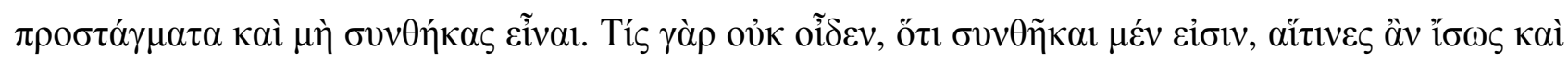

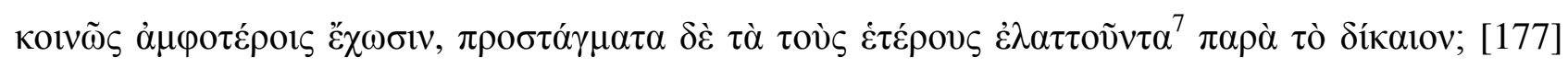

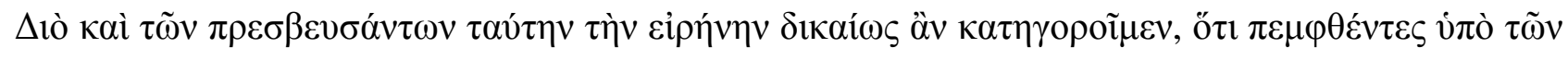

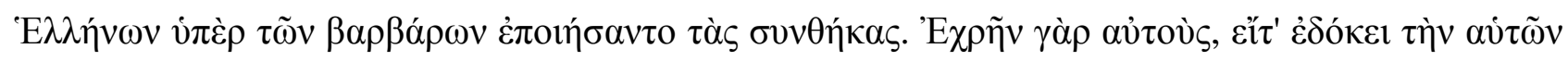

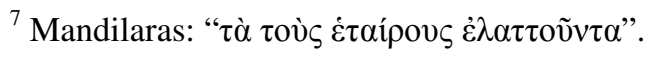




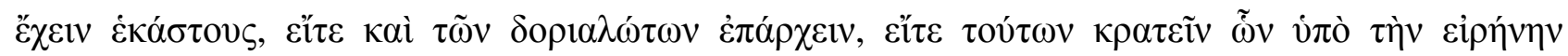

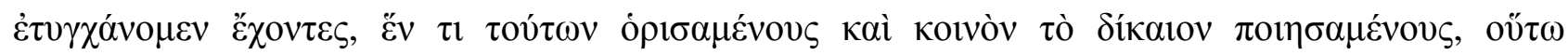

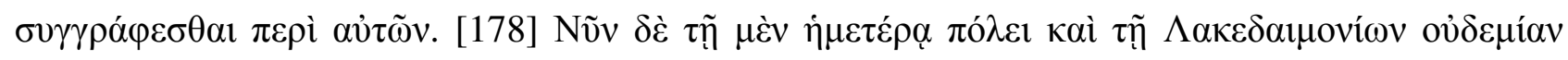

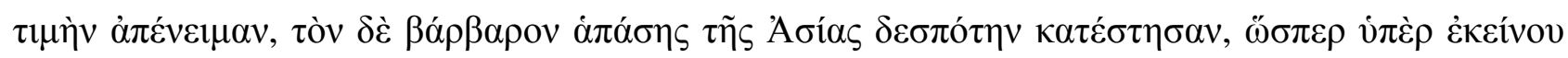

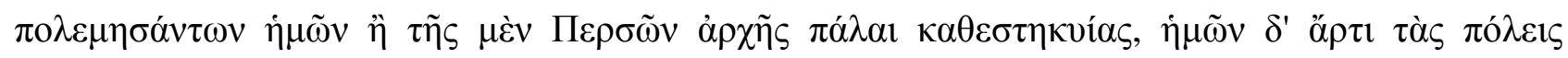

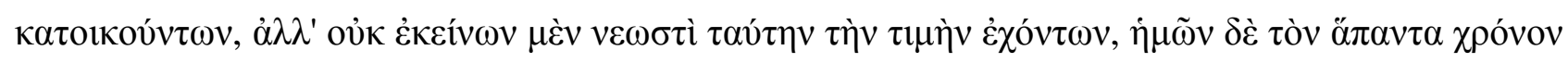

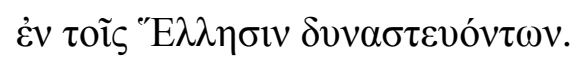

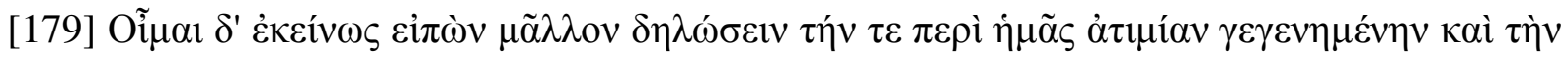

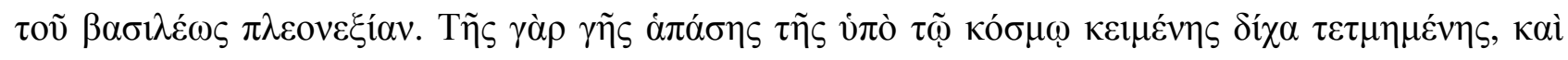

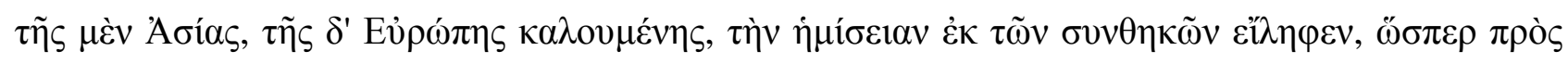

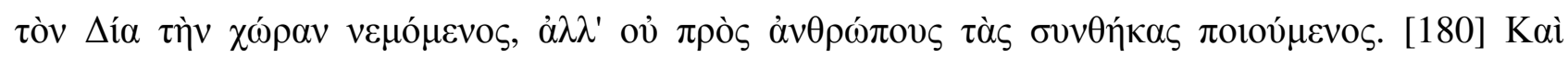

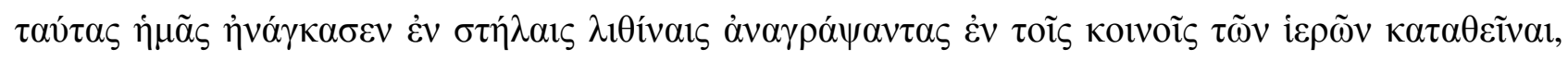

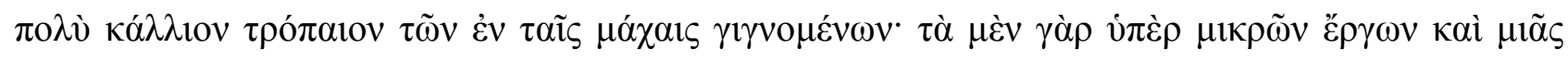

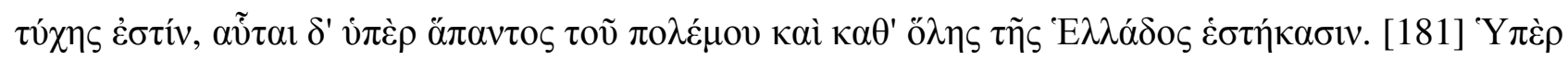

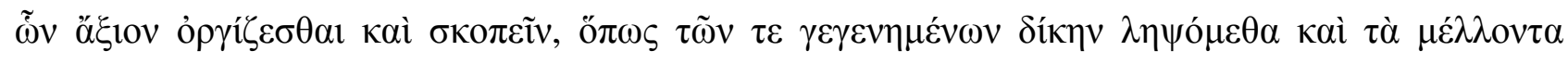

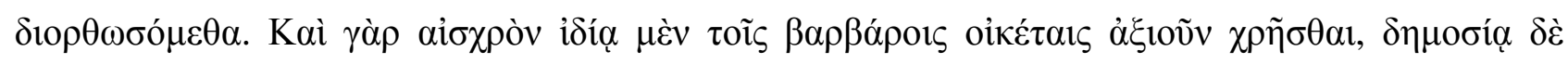

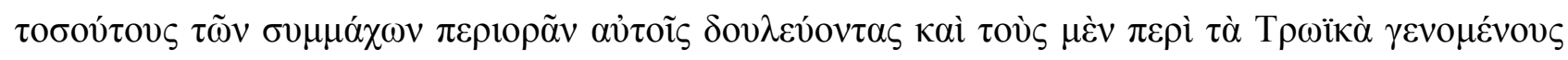

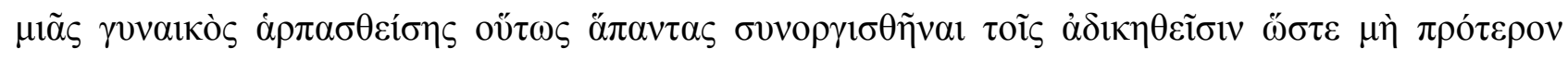

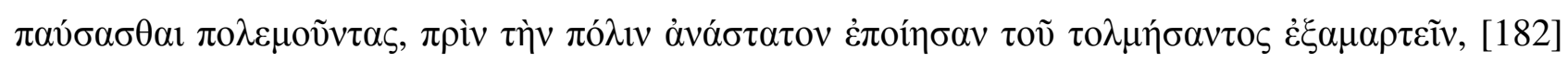

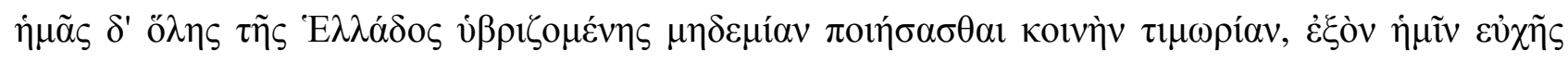

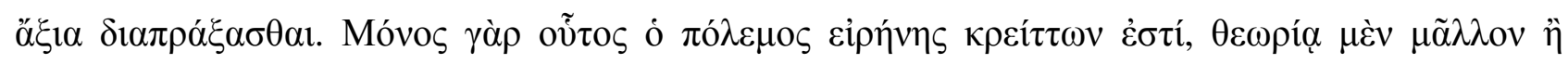

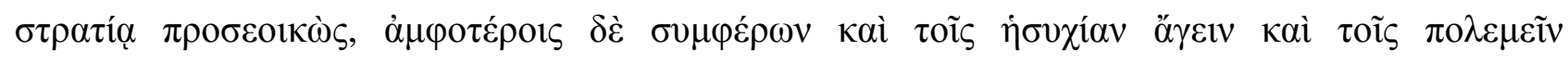

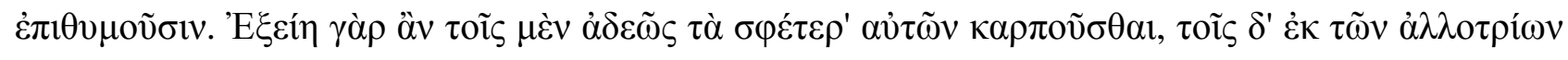

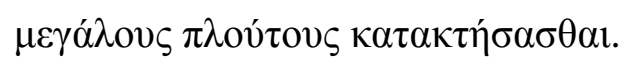




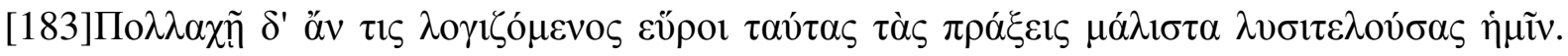

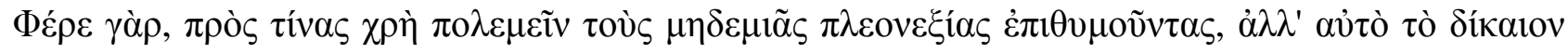

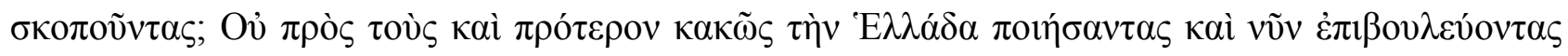

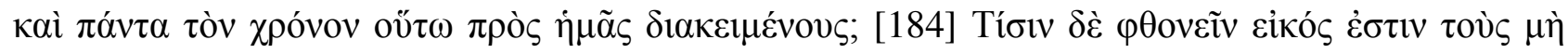

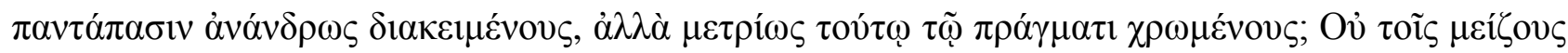

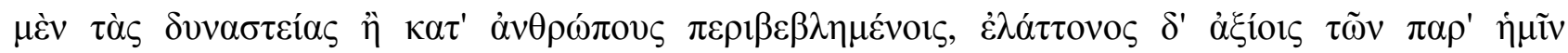

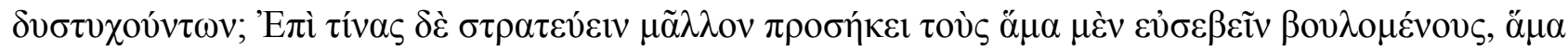

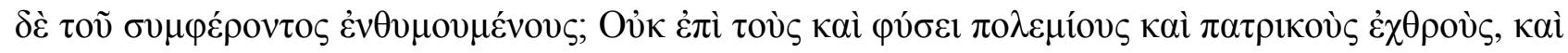

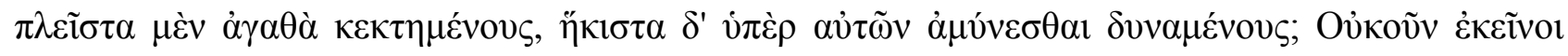

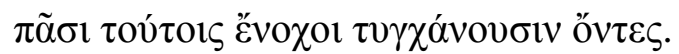

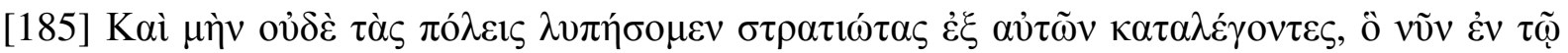

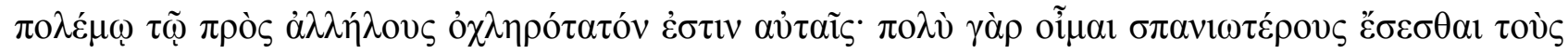

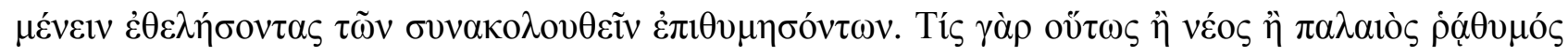

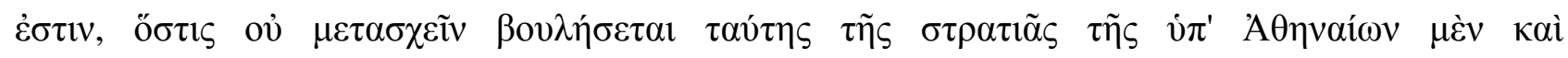

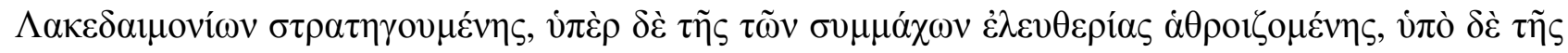

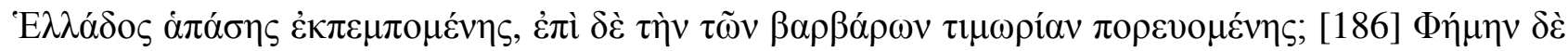

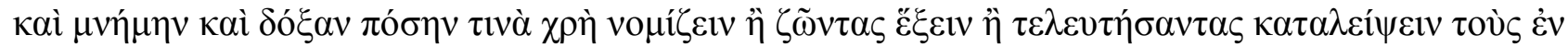

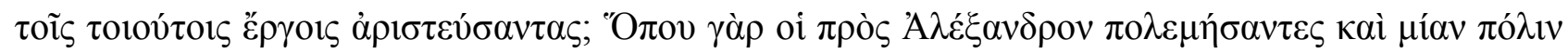

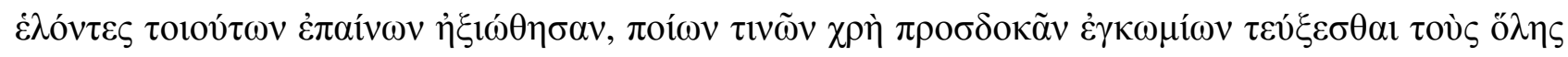

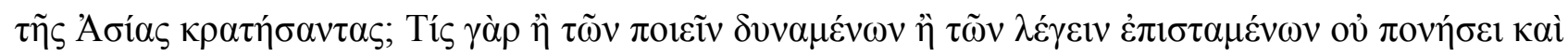


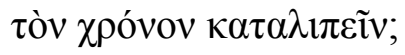

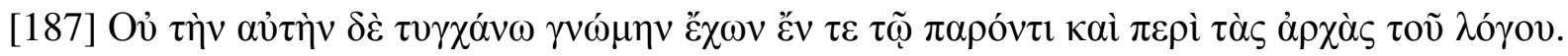

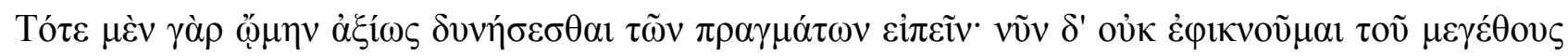

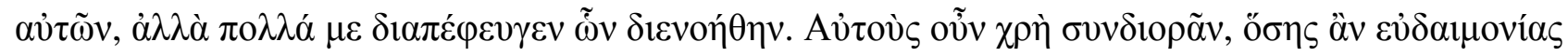




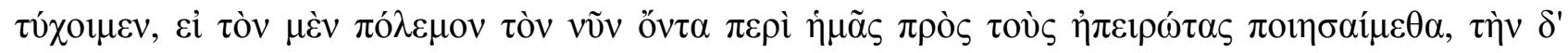

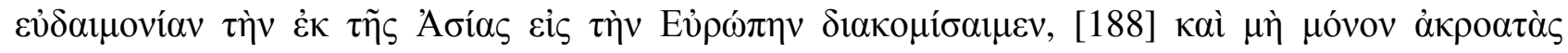

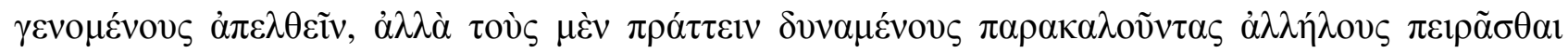

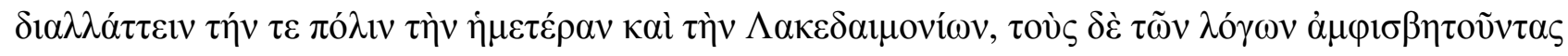

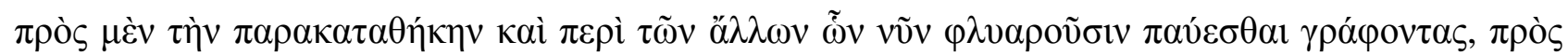

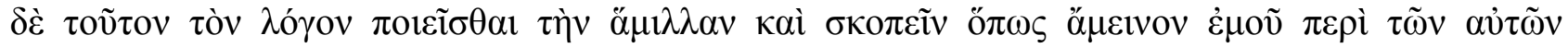

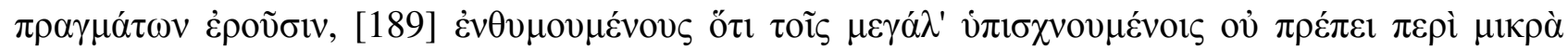

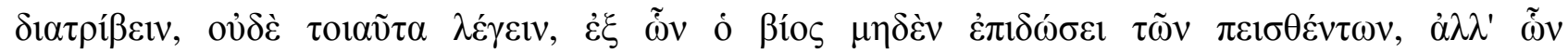

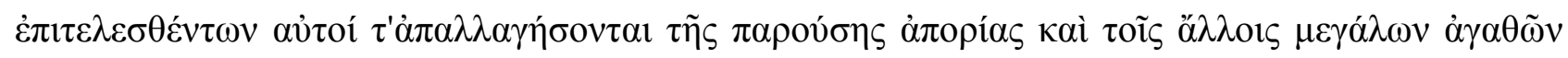

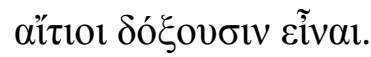


[1] Muitas vezes me admirei que os que convocaram as panegírias $^{1}$ e estabeleceram as competições atléticas tenham estimado os sucessos dos corpos merecedores de tão grandes privilégios, ${ }^{2}$ mas nenhuma honra tenham concedido aos que se esforçaram duramente em sua vida privada em favor do bem público e que prepararam as próprias almas de tal forma que também aos demais pudessem ser úteis [2] - é desses que seria razoável terem tido maior preocupação. Com efeito, mesmo se os atletas dobrassem a sua força, não haveria nenhuma vantagem para os demais; no entanto, se um só homem fosse sensato, beneficiar-se-iam todos os que quisessem partilhar de seu pensamento.

[3] Porém, sem ter sido desencorajado por essas coisas, decidi não permanecer ocioso, mas, considerando que me será prêmio suficiente a reputação que advier do meu próprio discurso, venho para aconselhar acerca da guerra contra os bárbaros e da concórdia entre nós mesmos. Não ignoro que muitos dos que professam ser sofistas ${ }^{3}$ se lançaram sobre este tipo de discurso, ${ }^{4}[4]$ mas espero distinguir-me de tal maneira que nada pareça ter sido dito pelos demais a esse respeito; ao mesmo tempo, julgo que os mais nobres discursos são aqueles que, tratando dos assuntos mais importantes, mais exibem os que falam e são os mais úteis aos que escutam: [5] este discurso é um deles. Ademais, as oportunidades ainda não passaram, de forma a ser doravante inútil lembrar essas coisas. Pois se deve deixar de falar ou quando os problemas tenham um fim e não mais se necessite deliberar a seu respeito, ou quando se perceba que o discurso atingiu o seu limite, de modo que nada mais possa ser acrescentado por outros. [6] Porém, enquanto tudo continuar como antes, mas as coisas que têm sido ditas forem insuficientes, como não seria necessário investigar e filosofar ${ }^{5}$ esse tipo de discurso, o qual, se for corretamente resolvido, nos livrará das guerras mútuas, da presente desordem e dos maiores males?

[7] Além disso, se só fosse possível expor os mesmos acontecimentos de uma única forma, poder-se-ia conceber como supérfluo outra vez aborrecer os ouvintes falando do mesmo modo que os predecessores, [8] mas, já que os discursos têm uma natureza tal que é possível dissertar de 
muitas formas diferentes a respeito das mesmas questões, e tornar humildes as coisas grandiosas e conferir às pequenas grandiosidade, e ainda relatar com novidade o que é antigo e falar de modo tradicional a respeito do que aconteceu recentemente, não mais se deve evitar o que outros falaram antes, mas tentar falar melhor do que eles. [9] Os acontecimentos do passado, com efeito, são um legado comum a todos nós, mas utilizar-se deles no momento oportuno, refletir a conveniência de cada um e bem dispô-los com as palavras é próprio dos que são sensatos. [10] E penso que não só as demais artes, mas especialmente a filosofia ${ }^{6}$ dos discursos alcançaria um enorme avanço se se admirassem e honrassem não os primeiros a iniciar tais atividades, mas aqueles que melhor efetuam cada uma delas; nem os que procuram discorrer a respeito do que ninguém nunca antes tratou, mas aqueles que sabem falar como nenhum outro seria capaz.

[11] Contudo, alguns censuram os discursos que estão além dos homens comuns e que são extremamente elaborados, cometendo o grave erro de julgar os discursos que foram compostos com o máximo de cuidado pelos mesmos critérios das contendas jurídicas sobre contratos privados, como se ambos devessem ser semelhantes, e não uns simples, os outros epidíticos, ${ }^{7}$ ou como se eles distinguissem como falar de modo ponderado, enquanto o que sabe falar com precisão não fosse capaz de fazê-lo com simplicidade. [12] Certamente a ninguém escapa que elogiam os que estão mais próximos a si mesmos; eu, no entanto, não tenho nada em comum com tais homens, e sim com os que não aceitarão o que se falar ao acaso, mas, ao contrário, que não o suportarão, e procurarão achar em meus discursos algo tal qual não encontrarão nos demais. A esses, depois de falar um pouco mais ousadamente a meu próprio respeito, farei o discurso sobre o assunto em questão. [13] Vejo, com efeito, que os demais, nos proêmios, acalmam os ouvintes, apresentam pretextos sobre o que vai ser dito e falam, uns, que sua preparação foi feita de improviso, outros, que é difícil encontrar palavras que se igualem à grandeza das coisas $;^{8}[14]$ quanto a mim, porém, se minha fala não estiver à altura do assunto, da minha própria reputação e do tempo - não só o que gastei com o discurso, mas também de todo o tempo de minha vida ${ }^{9}$-, recomendarei que não haja nenhuma 
desculpa, mas, ao contrário, o riso e o desdém, pois não há nenhuma de tais coisas que eu não mereça sofrer, se, não sendo em nada diferente dos demais, tão grandes promessas faço.

Quanto aos meus interesses particulares, pois, que isso que eu disse seja suficiente; [15] quanto aos interesses comuns, todos os que, logo que vêm falar, ensinam ser necessário colocarmos fim às inimizades entre nós mesmos e voltarmo-nos contra o bárbaro, ${ }^{10}$ descrevendo tanto as desgraças que nos têm sucedido com a guerra mútua quanto as vantagens que advirão da guerra contra aquele homem, eles dizem a verdade; porém, não começam de onde poderiam melhor alcançar essas coisas. [16] Pois, dos gregos, alguns estão sob o nosso domínio, os demais, sob o dos lacedemônios, já que as constituições, ${ }^{11}$ de acordo com as quais administram as cidades, ${ }^{12}$ assim têm separado grande parte deles. Quem, portanto, pensa que os demais farão algo de bom em comum antes que ele reconcilie seus líderes, é demasiado ingênuo e está distante das questões tratadas. [17] Mas quem não apenas faz uma exibição, mas também deseja realizar algo deve procurar os argumentos que persuadirão as duas cidades a partilhar igualmente entre elas, a dividir as hegemonias $^{13}$ e a tomar dos bárbaros as vantagens que, no presente momento, desejam obter para si mesmas às custas dos gregos. [18] É certamente fácil induzir nossa cidade a essas coisas; os lacedemônios, porém, ainda hoje são difíceis de persuadir, pois herdaram um falso relato: que governar lhes é um direito ancestral. Mas, se alguém lhes demonstrar que essa honra é mais nossa que deles, provavelmente deixariam de discutir minúcias a esse respeito e poderiam seguir o que é de seu interesse.

[19] Os demais, portanto, também deveriam começar daí e não dar conselhos acerca do que é de comum acordo antes de nos terem instruído sobre os pontos controversos; a mim, pois, cabe gastar a maior parte de meu tempo nessas questões, tendo em vista dois motivos: sobretudo para que nos ocorra algo de vantajoso e para que, depois de por fim à rivalidade entre nós mesmos, juntos combatamos os bárbaros; [20] mas, se isso é impossível, para que eu revele os que são 
obstáculo à prosperidade dos gregos e para que fique claro a todos que, no passado, a nossa cidade controlou com justiça o mar e que hoje ela não injustamente reclama a hegemonia.

[21] Porque, se, por um lado, devem ser honrados em cada atividade os que são mais experientes e capazes, incontestavelmente cabe a nós recuperar a hegemonia, a qual anteriormente detínhamos, pois ninguém poderia mostrar que outra cidade se sobressai tanto na batalha em terra quanto a nossa se distingue nos perigos do mar; [22] se, por outro, alguns consideram que essa avaliação não é justa, mas que ocorrem muitas vicissitudes, já que o poder nunca permanece por muito tempo nas mesmas mãos, e julgam que devem possuir a hegemonia, como um outro prêmio qualquer, quer os primeiros que obtiveram essa honra, quer os que são os responsáveis pelos maiores benefícios aos gregos, creio que também eles estão do nosso lado, [23] pois, quanto mais para trás no passado se investigar acerca dessas duas questões, mais para trás deixaremos os que nos contestam.

Admite-se, com efeito, que a nossa cidade é a mais antiga, a maior e a mais renomada entre todos os homens; mas, mesmo sendo tão nobre essa premissa, convém que sejamos ainda mais honrados pelo que segue: [24] habitamos essa terra sem ter expulsado outros daqui, nem a ocupamos estando desabitada, nem nos reunimos a partir da mistura de muitos povos, mas tão nobre e legítima é a nossa origem que vivemos durante todo o tempo sem cessar na mesma terra da qual brotamos, sendo autóctones ${ }^{14}$ e podendo chamar a cidade pelos nomes dos que nos são mais próximos, [25] pois, dos gregos, apenas a nós cabe chamá-la de nutriz, pátria e mãe. Ora, os que com razão se vangloriam, que com justiça reclamam a hegemonia e que frequentemente relembram os feitos dos ancestrais devem mostrar que sua linhagem teve uma origem tão nobre como essa.

[26] De tamanha grandeza são as dádivas iniciais que nos foram concedidas pela fortuna; de quantos benefícios aos demais somos os responsáveis, porém, poderíamos melhor examinar, se narrássemos uma a uma desde o princípio as realizações de nossa cidade, pois perceberemos que ela não só assumiu a responsabilidade dos riscos ante a guerra, mas também de quase todas as demais 
instituições, [27] nas quais habitamos, que nos tornam cidadãos e por meio das quais somos capazes de sobreviver. É necessário, porém, eleger, dentre os benefícios, não os que, por sua pequenez, foram completamente ignorados e silenciados, mas aqueles que, por sua grandeza, por todos os homens, os de agora, os de outrora e os de todo lugar, são falados e lembrados.

[28] Primeiramente, então, aquilo de que nossa natureza primeiro necessitou foi fornecido por nossa cidade; pois, mesmo se o relato tornou-se um mito, ainda agora, não obstante, convém contálo. Quando Deméter veio à nossa região, vagando após o rapto da Moça, ${ }^{15}$ ela se dispôs favoravelmente para com os nossos ancestrais em razão dos serviços prestados, os quais não podem ser contados a não ser aos iniciados, e concedeu duas dádivas - as maiores: as sementes, que são as responsáveis por não vivermos como as feras, e os ritos de iniciação, cujos participantes têm mais alegres esperanças acerca do fim da vida e de toda a eternidade. [29] Assim, nossa cidade amou não somente os deuses, mas também os homens, de forma que, tendo se tornado senhora de tantos bens, não desprezou os demais; ao contrário, do que se apossava, com todos compartilhava, e, ainda agora, revelamos, a cada ano, os ritos de iniciação; já quanto às sementes, ensinamos, em uma palavra, os usos, os labores e os benefícios que delas advêm.

E dessas coisas, depois de se ter acrescentado uns poucos detalhes, ninguém poderia pensar em descrer. [30] Porque, em primeiro lugar, as razões pelas quais se poderia desprezar o que eu disse, alegando ser algo antigo, são as mesmas para considerar razoável que tais acontecimentos tenham ocorrido, pois, pelo fato de muitos terem-nas contado e todos terem-nas ouvido, é apropriado julgar não que as coisas que foram ditas sobre isso são novidades, mas que elas são críveis. Em segundo lugar, podemos recorrer não somente ao fato de termos há muito recebido os relatos e a fama de tais acontecimentos, mas também nos valer de evidências ainda maiores que essas: [31] a maioria das cidades, com efeito, anualmente envia para nós, em lembrança do antigo benefício, os primeiros frutos da colheita, enquanto, às que deixaram de fazê-lo, a Pítia ${ }^{16}$ muitas vezes ordenou que enviassem sua parcela de grãos e que cumprissem os deveres ancestrais para 
com a nossa cidade. ${ }^{17}$ Ora, em que se deve ter maior fé, senão naquilo que o deus prescreve oracularmente e muitos dos gregos aprovam, naquilo que os relatos dos antigos confirmam juntamente com as ações do presente, quando os fatos recentes estão de acordo com as palavras dos antigos?

[32] À parte isso, porém, se deixarmos de lado todos esses argumentos e examinarmos a questão desde o princípio, perceberemos que os primeiros a aparecer sobre a terra não encontraram de pronto um modo de vida como o de agora, mas, aos poucos, eles próprios o fizeram tal como ele é hoje. Quais homens, então, devemos considerar que receberam isso como uma dádiva dos deuses ou, procurando, descobriram-no por conta própria? [33] Não são aqueles que todos reconhecem que surgiram primeiro e que são os mais propensos às artes e os mais reverentes aos deuses? E, ademais, quanta honra cabe obter os que foram responsáveis por tamanhos benefícios é desnecessário ensinar, pois ninguém seria capaz de encontrar uma dádiva cuja magnitude fosse igual ao que realizaram.

[34] Acerca do maior dos benefícios, pois, não só o primeiro, mas também o que é compartilhado por todos os homens, podemos dizer essas coisas. Naquele tempo, porém, os bárbaros ocupavam a maior parte da região, enquanto os gregos tinham sido confinados a um território pequeno e, por causa da escassez de terra, conspiravam entre si e enviavam expedições militares uns contra os outros, alguns deles perecendo por falta das provisões diárias, outros, por causa da guerra. [35] Atenas, ao ver tudo isso, não permitiu que a situação continuasse como estava, mas às cidades enviou comandantes, que, reunindo os mais necessitados, designaram a si como seus estrategos e dominaram na guerra os bárbaros. Eles fundaram muitas cidades nos dois continentes, colonizaram todas as ilhas e salvaram ambos - tanto os que os seguiam quanto os que ficavam, [36] pois a estes deixaram, em seu lar, terra suficiente e àqueles forneceram mais do que dispunham no início, tendo tomado posse de todo o território que agora ocupamos. ${ }^{18}$ De forma que os atenienses também tornaram muito mais fácil para os que mais tarde quiseram colonizar e imitar a 
nossa cidade, pois esses não precisavam se arriscar para adquirir terra, mas iam habitar a que por nós fora demarcada. [37] Ora, quem poderia exibir uma hegemonia mais ancestral do que essa, que surgiu antes da fundação da maioria das cidades helênicas, ou mais vantajosa do que a que fez os bárbaros se retirarem e conduziu os gregos à tamanha prosperidade?

[38] Ademais, depois de ter realizado as coisas mais importantes, não negligenciou as demais, mas fez deste o começo dos serviços - encontrar alimento para os necessitados -, precisamente o que deve fazer quem pretende bem também administrar os demais bens. Crendo, porém, que a vida limitada a essas condições ainda não era digna de se desejar vivê-la, preocupou-se tanto com o restante que, de todos os bens disponíveis aos homens que não recebemos dos deuses, mas que tiveram origem em nós mesmos, não houve nenhum sem o auxílio da nossa cidade e ela produziu a maior parte deles. [39] Pois, tendo encontrado os gregos vivendo sem lei e habitando dispersos, uns oprimidos por tiranias, outros perecendo por causa da anarquia, ela os livrou também desses males, passando a ser a senhora de alguns e tornando a si mesma exemplo para as demais, já que foi a primeira a instituir leis e a estabelecer uma constituição. ${ }^{19}$ [40] Isso é evidente pelo seguintes motivos: os que no princípio introduziram o julgamento de crimes de assassinato e quiseram pela razão [logos] e não pela força solucionar os conflitos entre si, pelas nossas leis julgaram sobre tais questões. $^{20}$ Além disso, também as artes, tanto as úteis às necessidades da vida quanto as que foram preparadas para o prazer, Atenas aos demais transmitiu, já que ela descobriu as primeiras e aprovou o uso das outras. [41] O restante da administração, então, ela estabeleceu de forma tão hospitaleira e amigável para com todos que é adequada a ambos, tanto aos despossuídos quanto aos que desejam desfrutar dos seus recursos, e nem aos prósperos nem aos desafortunados deixa que permaneçam ociosos em suas próprias cidades, mas, entre nós, os primeiros encontram as mais deleitosas distrações, os outros, o refúgio mais seguro. [42] E além disso, visto que nenhum deles possuía um território autossuficiente, mas careciam de algumas coisas e produziam outras mais do que era preciso, e como era muito difícil tanto dispor das primeiras nos lugares onde eram necessárias 
quanto levar as outras alhures, também essas dificuldades Atenas remediou, pois estabeleceu o Pireu $^{21}$ como um mercado no centro da Grécia, cuja abundância é tamanha que esses artigos, difíceis de se obter individualmente, são todos encontrados com facilidade nela.

[43] Ademais, com justiça se louvam os que estabeleceram as panegírias, pois eles nos transmitiram um costume tão nobre que, após fazer as libações ${ }^{22}$ e pôr um fim às inimizades vigentes, podemos nos reunir em um mesmo lugar, onde, em seguida, oferecemos juntos preces e sacrifícios, lembramo-nos de nosso comum parentesco e nos dispomos uns com os outros de forma mais benevolente no futuro, não só renovando os antigos, mas também estabelecendo novos laços de hospitalidade. [44] E nem aos homens comuns, nem aos que se distinguem pela forma física o tempo que ali se passa é infrutífero, mas, reunida essa multidão de gregos, podem os atletas exibir as próprias proezas e os espectadores assistir àqueles disputando entre si. E nenhum deles ali passa o tempo sem entusiasmo, mas cada um tem do que se orgulhar: os espectadores, quando veem os competidores se esforçarem duramente por sua causa, e os atletas, quando pensam que todos vieram para admirá-los. Sendo tantos, pois, os benefícios que nos advêm de tais reuniões, também nisso nossa cidade não ficou para trás. [45] Com efeito, ela possui os mais numerosos e os mais belos espetáculos, uns, excedendo todos os gastos, alguns, reputados por causa de sua arte, outros distinguindo-se em ambos os aspectos. E tamanha é a multidão dos que nos visitam que, se há algo de bom em nos reunirmos uns com os outros, isso também foi conquistado por Atenas. Ademais, somente entre nós é possível achar as mais fiéis amizades e encontrar os grupos mais variados, e ainda assistir a competições não apenas de rapidez e força, mas também de discursos $[$ logoi $],{ }^{23}$ de inteligência e de todas as demais atividades. E todas elas têm maiores prêmios em Atenas, [46] porque, além dos que a própria cidade oferece, ela também convence os demais a fazê-lo, pois nossas decisões adquirem tamanho renome que são aceitas por todos os homens. Além disso tudo, as demais panegírias, que levam muito tempo para se reunir, terminam rapidamente, mas a nossa cidade é durante todo o tempo, para os que a visitam, uma panegíria. ${ }^{24}$ 
[47] À filosofia, ${ }^{25}$ ademais, que todas essas coisas ajudou a descobrir e estabelecer, e para a vida pública nos educou e nos tornou gentis uns com os outros, que distinguiu os infortúnios, uns advindos da ignorância, outros, da necessidade, e nos ensinou a nos proteger dos primeiros e a suportar dignamente os últimos, a ela nossa cidade revelou. E dignificou os discursos, ${ }^{26}$ que todos desejam e invejam os homens que a conhecem, [48] porque ela sabe que, de todos os animais, somos por natureza os únicos a possuir essa particularidade e que, superando-os nisso, em tudo mais somos superiores a eles. E ela também percebe que, nas demais atividades, os sucessos são tão incertos que muitas vezes os homens sensatos aí fracassam e os tolos têm êxito; nos discursos [logoi] nobres e artísticos, ${ }^{27}$ porém, não tomam parte os homens comuns, mas isso é obra de uma mente perspicaz. [49] Ela também sabe que é nisso que mais se distinguem uns dos outros os que são julgados sábios ou ignorantes, e ainda que quem foi educado desde o princípio como um homem livre é reconhecido não pela coragem, riqueza ou bens semelhantes, mas sobretudo pelo que diz, e isso tem provado ser o sinal mais seguro da educação de cada um de nós; e ela percebe que os que se utilizam bem da fala [logos] são poderosos não somente em suas cidades, mas também são honrados entre os demais. [50] Nossa cidade está tão à frente do restante dos homens no pensar e no falar que seus alunos se tornam os professores dos demais, e que ela fez com que o nome dos gregos parecesse não mais à raça, mas à inteligência pertencer, e fez com que sejam chamados de gregos mais os que partilham da nossa educação do que da natureza comum.

[51] Mas, a fim de não parecer que eu me alongo sobre as partes, depois de ter me proposto a tratar das questões gerais, nem que a partir dessas coisas faço encômios à cidade por não saber elogiar seus feitos na guerra, o que eu disse seja suficiente em relação aos que são honrados por tais ações; creio, porém, que não se deve honrar menos os nossos ancestrais pelos perigos da guerra do que pelos demais benefícios. [52] Pois não enfrentaram nem pequenos, nem poucos, nem obscuros combates, mas muitos, terríveis e grandiosos, uns por suas próprias terras, outros, pela liberdade dos demais: pois sem cessar ofereceram a cidade como refúgio comum e socorreram sempre aqueles os 
gregos que foram injustiçados. [53] Por isso mesmo alguns nos acusam, alegando que não deliberamos corretamente, porque costumamos atender aos que são mais fracos, como se tais argumentos não fossem daqueles que querem nos elogiar. Pois, de tal modo deliberamos a respeito dessas questões, que não ignoramos o quanto são importantes para a segurança as alianças com os mais poderosos. Mas, embora sabendo com maior precisão que os demais as consequências de tais associações, preferimos, não obstante, mesmo de modo desfavorável, socorrer os que são mais fracos a cometer injustiças aliados aos mais fortes por causa das vantagens.

[54] Mas poder-se-ia reconhecer o modo de ser e a força da cidade a partir das súplicas que alguns já nos rogaram. Deixarei, pois, de lado tanto as que aconteceram recentemente quanto as que pediam coisas de pouca importância, mas muito tempo antes da guerra de Troia - é justo que daí retirem seus argumentos os que disputam sobre os direitos ancestrais - vieram até nós os filhos de Héracles e, um pouco antes deles, Adrasto, filho de Talau, rei de Argos: [55] este fracassara em sua campanha contra Tebas e não fora capaz por si mesmo de recolher os corpos dos que caíram aos pés da cidadela de Cadmo, mas estimava que a nossa cidade vem em socorro nas desgraças comuns e que não permite os mortos em batalha ficarem sem jazigo nem um costume antigo e uma lei ancestral serem abolidos. [56] Os filhos de Héracles, por sua vez, fugiram do ódio de Euristeu e desdenharam as demais cidades, crendo que elas não seriam capazes de socorrê-los, mas consideravam que apenas a nossa seria suficiente para retribuir os serviços prestados por seu pai a todos os homens.

[57] A partir disso é fácil perceber que mesmo naquele tempo nossa cidade era hegemônica: pois quem ousaria fazer súplicas aos que são mais fracos ou que estão sob o domínio de outros, deixando de lado os que detêm maior poder, especialmente acerca de questões não particulares, mas de interesse comum, e acerca das quais seria razoável que nenhum outro cuidasse, senão os que são considerados dignos de liderar todos os gregos? [58] Além disso, ficou evidente que não estavam enganados quanto às esperanças que os fizeram se refugiar entre os nossos ancestrais. Pois, 
encarregando-se de guerrear contra os Tebanos em favor dos que encontraram seu fim na batalha, e contra o poder de Eristeu em favor dos filhos de Héracles, lançando-se em campanha contra os primeiros, obrigaram-nos a devolver os corpos para que os familiares os enterrassem; por sua vez, indo ao encontro dos peloponésios que com Eristeu invadiram nossa região, venceram-nos em batalha e fizeram com que cessasse a insolência daquele. [59] Já admirados pelas outras realizações, graças a essas façanhas adquiriram ainda maior reputação. Pois não fizeram só isso, mas também alteraram tanto a fortuna de cada um que aquele que estimou nos suplicar auxílio contra a força de seus inimigos, depois de obter absolutamente tudo o que demandou, partiu; enquanto Eristeu, julgando que nos subjugaria pela força, ele próprio, depois de ter sido capturado, foi forçado a se apresentar como suplicante. ${ }^{28}$ [60] Sim, Eristeu, que o tempo todo sem cessar ordenou e ultrajou quem superou a natureza humana - o filho de Zeus -, que, embora fosse mortal, possuía a força de um deus. Mas quando ele agiu erroneamente contra nós, sofreu tamanha guinada em sua sorte que terminou a vida de forma desonrosa, ${ }^{29}$ ao se tornar cativo dos filhos de Héracles.

[61] Ainda que tenhamos prestado muitos benefícios à cidade dos lacedemônios, acabei falando apenas desse. Pois, a partir da salvação que nós lhes asseguramos, os ancestrais dos que hoje reinam na Lacedemônia - os filhos de Héracles - retornaram do exílio ao Peloponeso, tomaram o controle de Argos, da Lacedemônia e de Messena, tornaram-se os fundadores de Esparta e tornaram-se como os autores de todos os presentes bens dos espartanos. [62] Tendo isso na memória, os lacedemônios jamais deveriam invadir a região da qual, ao partir, eles obtiveram tamanha prosperidade; nem colocar em risco a cidade que se arriscou pelos filhos de Héracles; nem deveriam conceder a realeza ${ }^{30}$ aos seus descendentes e, depois disso, pensar em escravizar para seu próprio benefício a cidade que é a responsável pela salvação de sua linhagem. [63] Se se deve, porém, renunciando à gratidão e à equidade, retornar novamente à premissa inicial e usar o argumento mais preciso, de modo nenhum faz parte da tradição ancestral os recém chegados aos autóctones comandar, nem os beneficiados aos seus benfeitores, nem os suplicantes aos que lhes 
deram abrigo. [64] Mas posso expor isso com maior concisão: com efeito, as maiores cidades gregas, com exceção da nossa, eram então Argos, Tebas e a Lacedemônia, e ainda hoje continuam a sê-lo. Mas os nossos ancestrais se distinguiram tão claramente de todos que, em defesa dos vencidos argivos, impuseram seu comando sobre os tebanos, quando esses foram extremamente arrogantes; [65] em defesa dos filhos de Héracles, dominaram em combate argivos e os demais peloponésios; dos perigos da luta contra Eristeu, preservaram os fundadores e os comandantes lacedemônios. Assim sendo, acerca do nosso poder entre os gregos, não sei como poderia haver uma demonstração mais clara.

[66] Julgo, porém, que também convém falar das façanhas realizadas pela cidade contra os bárbaros, especialmente porque propus o discurso sobre a hegemonia na luta contra eles. Bem, se eu enumerasse todas as situações de perigo, o discurso seria excessivamente longo; do mesmo modo como fiz agora há pouco, pois, tentarei narrar as mais importantes. [67] Os citas, os trácios e os persas são, com efeito, os povos mais ávidos por mandar e que têm maior poder de dominação. Todos eles conspiraram contra nós e a cidade contra todos correu grande perigo. Ora, o que mais poderão dizer nossos opositores, se se mostrar que, dos gregos, os incapazes de obter as coisas justas julgaram digno ser nossos suplicantes, enquanto, dos bárbaros, os desejosos de escravizar os gregos vieram primeiro contra nós?

[68] Certamente, das guerras, a mais famosa foi a que lutamos contra os persas; aos que contestam nosso legado ancestral, porém, não menor prova são os eventos antigos. Pois, quando a Grécia ainda era fraca, vieram a nossa região os trácios com Eumolpo, filho de Posêidon, e também os citas, com o auxílio das amazonas, filhas de Ares - não ao mesmo tempo, mas no momento em que cada um deles tentava dominar a Europa. Embora odiassem todos os gregos, faziam particularmente acusações contra nós, julgando que, dessa maneira, correriam o risco de guerrear contra uma única cidade, mas dominariam de uma só vez todas elas. [69] Porém, não obtiveram sucesso, mas, em luta apenas contra nossos ancestrais, foram destruídos de forma igual a que se 
tivessem lutado contra absolutamente todos os homens da terra. É evidente a magnitude dos males que os atingiram, pois os relatos a seu respeito nunca perdurariam tanto tempo, se os seus feitos fossem comparáveis aos demais. [70] Conta-se, pois, sobre as amazonas, que, das que partiram, nenhuma retornou, enquanto as que haviam permanecido em sua terra, por causa do infortúnio que aqui ocorreu, foram tiradas do comando. Sobre os trácios, afirma-se que, outrora vizinhos, por causa da campanha militar de então, afastaram-se tanto de nós que, no espaço entre as duas regiões, estabeleceram-se muitos povos, variadas raças e grandes cidades.

[71] São, portanto, não apenas nobres essas ações, mas também apropriadas aos que reclamam a hegemonia; porém, da mesma natureza das que foram mencionadas e do mesmo tipo que é razoável esperar dos descendentes de tais homens, foram as ações que empreenderam aqueles que lutaram contra Dario e Xerxes. Pois, embora aquela guerra fosse a maior de todas, houvesse incontáveis perigos, os inimigos pensassem ser invencíveis por causa de seu grande número e seus aliados acreditassem possuir um virtude ${ }^{31}$ insuperável, [72] porque a ambos nossa cidade derrotou como convinha a cada um e distinguiu-se em todos os perigos, ela imediatamente foi considerada digna de obter as maiores honras. Não muito tempo depois, assumiu o domínio do mar, concedido pelos demais gregos, sem nos contestarem os que dele hoje procuram nos privar.

[73] E que ninguém pense que eu desconheço os muitos benefícios de que, nessas mesmas oportunidades, os lacedemônios também foram responsáveis para os gregos. Mas também por isso posso elogiar ainda mais a cidade, porque, mesmo com tais rivais, ela conseguiu de tantas maneiras superá-los. Desejo falar um pouco mais sobre as duas cidades e não passar demasiado rapidamente para o próximo ponto, a fim de que nos recordemos da virtude de nossos ancestrais e de seu ódio contra os bárbaros. [74] Ora, não me escapa a dificuldade de vir falar por último de ações que já há muito foram tratadas e sobre as quais, dos cidadãos, os mais capacitados no falar têm frequentemente se pronunciado nas cerimônias fúnebres publicamente realizadas; pois necessariamente as mais importantes já foram utilizadas e só foram deixadas as de menor valor. 
Não obstante, iniciando pelas que foram deixadas de lado, já que são apropriadas ao assunto de meu discurso, não hesitarei em lembrá-las. ${ }^{32}$

[75] Creio que os responsáveis pelos mais numerosos benefícios e os merecedores dos maiores elogios foram os que arriscaram suas vidas pela Grécia; não é justo, porém, esquecer dos homens que viveram antes dessa guerra e que comandaram cada uma das duas cidades, pois eles prepararam seus sucessores, direcionaram as multidões à virtude e tornaram-nos implacáveis adversários dos bárbaros. [76] Pois eles não faziam pouco do que era comum a todos, nem se beneficiavam disso como se fosse seu, nem o negligenciavam como algo alheio; ao contrário, cuidavam disso como assuntos familiares, mas mantinham a devida distância do que não lhes concernia. Nem avaliavam a felicidade pelo dinheiro, mas julgavam possuir a riqueza mais segura e nobre o homem que porventura realizasse ações a partir das quais garantiria a si mesmo maior renome e que transmitiria aos filhos a maior reputação. [77] Nem invejavam uns aos outros pelas ações audaciosas, nem cultivavam a própria ousadia, mas consideravam mais terrível ser mal falados pelos cidadãos do que morrer nobremente pela cidade; envergonhavam-se mais dos erros cometidos contra o interesse comum do que os cidadãos de hoje o fazem em relação aos próprios.

[78] Essa era a razão pela qual investigavam como as leis seriam precisas e boas, não se preocupando tanto com as normas dos contratos privados quanto com as que regulam as atividades cotidianas. Pois reconheciam que, para os homens bons e nobres, não seriam necessárias muitas leis escritas, mas, a partir de umas poucas convenções, eles facilmente chegariam a um acordo tanto nas questões públicas quanto nas privadas. [79] Viviam tão intensamente a política que provocavam dissensões internas, ${ }^{33}$ não porque desejassem ambos os lados dominar os demais para aniquilar os outros, mas porque ambos se precipitavam a fazer algum bem à cidade; e formavam facções ${ }^{34}$ não por causa das vantagens próprias, mas em benefício da multidão. [80] Dessa mesma maneira administravam também os interesses dos demais: prestavam serviços aos gregos sem ultrajá-los, pensando que deviam ser seus estrategos, não seus tiranos. E preferiam ser chamados de 
comandantes, não de senhores; ser nomeados de salvadores, não opressores; e conduziam as cidades por sua benevolência, não as subjugavam pela força. [81] Seus discursos eram mais confiáveis do que os juramentos de hoje; consideravam como necessário cumprir os acordos; nem se orgulhavam tanto de seu poder quanto honrosamente procuravam viver com moderação; e estimavam que, quanto aos mais fracos, deviam ter a mesma consideração que os mais fortes têm de si mesmos. Eles viam suas cidades [poleis] como espaços urbanos próprios $[$ astēe $],{ }^{35}$ mas consideravam que a Grécia era sua pátria comum.

[82] Ao utilizar tais noções e educar os mais jovens em tais costumes, revelaram os que guerrearam contra os habitantes da Ásia serem homens tão bons que ninguém sobre isso - nem poeta, nem sofista - jamais foi capaz de dignamente das ações que realizaram. E muito lhes desculpo, pois é igualmente difícil elogiar os que superaram os demais na virtude assim como os que nada de bom fizeram. Com efeito, a uns não se seguem as ações; quanto aos outros, não há discursos adequados a suas façanhas. [83] Pois como poderia haver discursos proporcionais a tais homens, os quais diferiram tanto dos que combateram contra Troia que, enquanto estes levaram dez anos no cerco de uma única cidade, aqueles em pouco tempo subjugaram todo o poder da Ásia, pois não apenas cada um salvou a própria pátria, como também eles libertaram toda a Grécia? De qual façanha, pena ou perigo se esquivaram para serem honrados ainda vivos, eles que, pela reputação que imediatamente obteriam ao atingir o fim da vida, tão prontamente consentiam em morrer? [84] Penso, além disso, que algum deus, admirando-lhes a virtude, provocou a guerra, para que homens de tão nobre natureza não fossem esquecidos nem sem glória alcançassem o fim da vida, mas fossem dignos das mesmas honras que são concedidas aos filhos dos deuses, os chamados semideuses, pois também estes, devolvendo o corpo às necessidades da natureza, tornaram imortal a memória de sua virtude.

[85] Ora, os nossos ancestrais e os lacedemônios sempre emulavam entre si; não obstante, naqueles tempos disputaram pelas coisas mais nobres, considerando a si mesmos não como 
inimigos, mas rivais; já que não prestavam serviço ao bárbaro para escravizar os gregos, mas concordavam acerca salvação comum, disputando qual dos dois seria o responsável por ela, sobre essa questão deflagrando o conflito. Exibiram primeiro a própria virtude no combate contra a expedição enviada por Dario. [86] Pois, quando os persas desembarcaram na Ática, os atenienses não esperaram os aliados, mas, ao tornar a guerra comum sua guerra particular, iam de encontro aos que menosprezavam toda a Grécia apenas com sua própria força: uns poucos homens contra muitas dezenas de milhares, como se fossem arriscar as vidas de outros. Os lacedemônios, por outro lado, tão logo souberam da guerra em torno da Ática, deixaram todo o resto para trás e vieram nos defender com um zelo semelhante àquele que teriam caso sua própria terra estivesse sitiada. Eis a prova da sua rapidez e rivalidade: [87] afirmam que os nossos ancestrais, no mesmo dia em que souberam do desembarque dos bárbaros, correram para defender as fronteiras da Ática, venceram os bárbaros em batalha, e levantaram um troféu sobre os inimigos; quanto aos lacedemônios, afirmam que, em três dias e o mesmo número de noites, o exército atravessou a pé mil e duzentos estádios, tamanho era o ardor: uns, de participar dos perigos; outros, de se lançar ao combate antes que aqueles chegassem para os socorrer.

[88] Depois disso, ocorreu a segunda expedição, liderada pelo próprio Xerxes, que, deixando seu palácio e ousando impor-se como estratego, reuniu todos os homens da Ásia. Sobre ele, quem não disse menos do que a realidade, ainda que desejando exagerar? [89] A arrogância desse homem chegava a tal extremo que, pensando ser uma tarefa pequena subjugar a Grécia, mas desejando deixar um monumento que estivesse além da natureza humana, não parou até descobrir e realizar isso que todos repetem, de forma que fez o exército não só navegar através do continente, mas também marchar pelo mar, unindo as margens do Helesponto e cavando através do monte Atos. ${ }^{36}$ [90] Contra homem tão arrogante, que realizou tão grandes façanhas e fez-se senhor de inúmeros povos, resistiram, dividindo o perigo entre si: os lacedemônios foram para as Termópilas lutar contra a infantaria com mil soldados escolhidos dentre os seus, além de uns poucos aliados que 
levaram consigo, a fim de que, nos desfiladeiros, impedissem os inimigos de avançar mais, enquanto os nossos pais, navegando para Artemísio, equiparam sessenta trirremes para derrotar toda a frota dos inimigos. [91] Ousavam fazer essas coisas não tanto porque menosprezavam os inimigos, mas para emularem entre si: os lacedemônios, invejando nossa cidade pela batalha de Maratona e procurando se igualar a nós, temiam que duas vezes seguidas nossa cidade se tornasse a responsável pela salvação dos gregos; os nossos ancestrais, por sua vez, desejavam mais do que tudo preservar a presente reputação e tornar evidente a todos que também, no passado, venceram pela virtude, não pelo acaso; e, ademais, também desejavam levar os gregos ao combate marítimo, mostrando-lhes que tanto nos perigos do mar quanto nos da terra a virtude supera um grande contingente.

[92] Mesmo tendo demonstrado igual ousadia, não tiveram a mesma sorte. Ao contrário, os lacedemônios foram destruídos e, vitoriosos pelo ânimo, falharam com seus corpos - pois não é justo dizer que foram derrotados, visto que nenhum deles pensou em fugir; quanto aos nossos, venceram a frota avançada e, depois de escutarem que os inimigos dominavam a passagem, navegaram para casa. E tão bem decidiram sobre o resto que, tendo de antemão realizado muitas e nobres ações, nos derradeiros perigos se distinguiram ainda mais. [93] Pois, quando todos os aliados estavam abatidos e os peloponésios bloqueavam o Istmo com uma muralha e buscavam sua própria salvação, e as demais cidades (exceto as que, por sua insignificância, foram ignoradas) haviam caído sob o domínio dos bárbaros e os auxiliavam em suas campanhas; quando iam ao ataque mil e duzentas trirremes, e a infantaria, formada por incontáveis homens, estava a ponto de invadir a Ática, naquele momento, quando os atenienses não entreviam nenhuma salvação, mas não dispunham de aliados e viam serem frustradas todas suas esperanças, [94] foi-lhes possível não somente fugir dos perigos presentes, mas também auferir honras excepcionais, as quais lhes oferecia o rei, na crença de que, se obtivesse o apoio da frota ateniense, imediatamente também dominaria o Peloponeso. Não aceitaram suas ofertas, nem tampouco, irados com os demais gregos 
por terem sido abandonados, alegremente se precipitaram numa reconciliação com os bárbaros, ${ }^{37}$ [95] mas, enquanto se preparavam para lutar sozinhos pela liberdade, perdoavam os demais por preferir a escravidão. Pois consideravam que convinha às pequenas cidades buscar a salvação de todas as maneiras possíveis; que, por sua vez, não era permitido às que se julgavam dignas de comandar a Grécia fugir dos perigos. Ao contrário, consideravam que, tal como aos homens bons e nobres é preferível morrer nobremente a viver em desgraça, assim também, às cidades mais importantes, é preferível desaparecer da face da terra do que ver-se como escravas. [96] Evidentemente os atenienses pensaram tais coisas. Pois, já que não eram capazes de organizar-se ao mesmo tempo contra os ataques terrestre e marítima, recolheram toda a população da cidade e navegaram para a ilha vizinha, a fim de enfrentar separadamente cada um deles. ${ }^{38}$

Ora, como seria possível exibir homens melhores e mais filo-helenos que esses, que, para não se tornar os responsáveis pela escravidão dos demais, suportaram ver sua cidade deserta, sua terra sendo saqueada, os lugares sagrados sendo pilhados e os templos incendiados, e toda a guerra acontecendo em sua própria pátria? [97] E nem isso lhes satisfez, mas, ao contrário, estiveram a ponto de lutar sozinhos contra mil e duzentas trirremes. Não lhes foi permitido, no entanto, fazer isso, pois os peloponésios envergonharam-se ante a grande virtude daqueles homens e consideraram que, se os nossos fossem destruídos, também eles não seriam salvos. E consideraram que, se os atenienses tivessem sucesso, suas próprias cidades seriam desonradas. Assim, foram constrangidos a tomar parte nos perigos. Do tumulto que surge na ação, dos gritos e exortações, que são comuns a todas as batalhas navais, não vejo por que passar o tempo mencionando tais detalhes; [98] mas os eventos singulares, dignos da hegemonia e de acordo com o previamente dito, é minha tarefa expor. Pois nossa cidade era tão superior quando não tinha sido conspurcada que, mesmo depois de destruída, ela contribuía para a guerra em favor da Grécia com mais trirremes do que todos os outros que combateram no mar. Não haveria ninguém tão contrário a nós que não reconheceria que dominamos a guerra por meio dos combates marítimos e que a cidade foi responsável pela vitória. 
[99] Ora, se houver uma campanha contra os bárbaros, a quem caberá a hegemonia? Não será aos homens que, na guerra anterior, mais se distinguiram, muitas vezes, isoladamente, correndo perigo, enquanto, nos combates comuns, foram merecedores das maiores recompensas? Não aos homens que abandonaram sua própria terra para salvar os demais? Aqueles que nos tempos antigos fundaram a maioria das cidades e depois salvaram-nas dos maiores infortúnios? Não receberíamos um tratamento injusto, se, depois de termos participado da maior parte dos males, fôssemos julgados merecedores da menor parte das honras? Se, depois de ficar à frente na defesa de todos, agora fôssemos obrigados a seguir os demais?

[100] Bem, até aqui, sei que todos reconheceriam que a nossa cidade foi a responsável pela maioria dos benefícios e que a hegemonia seria sua por direito; logo após esses acontecimentos, porém, alguns nos acusam de, depois que obtivemos o domínio sobre o mar, nos tornamos, segundo eles, causa de diversos males contra os gregos. E citam, em seus discursos, a escravização dos mélios e a destruição dos cionenses. [101] Eu creio, antes de mais nada, que não é prova alguma de que governamos mal, se alguns dos que guerrearam contra nós parecem ter sido castigados com severidade, mas evidência muito maior de que administrávamos bem os interesses dos aliados é que nenhuma das cidades que estavam sob o nosso comando sofreram infortúnios semelhantes. [102] Além disso, se outros tivessem cuidado das mesmas questões de forma mais complacente, seria razoável que nos censurassem; mas, se nem isso ocorreu, nem é possível comandar uma quantidade tão grande de cidades sem castigar os transgressores, como não seria justo nos elogiar agora, nós que, sendo severos com tão poucos, fomos capazes de manter o nosso domínio por maior tempo possível?

[103] Penso que todos julgam que se tornarão comandantes mais poderosos dos gregos aqueles sob o comando dos quais quem obedeceu realizou o melhor. Durante nossa hegemonia, então, constataremos que não só a organização familiar $^{39}$ muito prosperou, mas também que as cidades engrandeceram. [104] Pois não invejávamos cidades que prosperavam nem semeávamos 
discórdia, implementando constituições contrárias, para que os cidadãos criassem, uns contra os outros, facções, e ambos os lados servissem a nós. Considerávamos, ao contrário, que a concórdia entre os aliados era um benefício comum e pelas mesmas leis administrávamos todas as cidades. Deliberávamos sobre elas como aliados, não como déspotas, estando à frente de todas as questões da aliança, mas deixando cada membro livre para tratar de seus assuntos particulares. [105] Vindo em socorro da multidão, lutávamos contra os poderosos, considerando como terrível que poucos dominassem muitos e que homens desprovidos de recursos, mas que em todo o resto não eram em nada inferiores àqueles, fossem afastados dos cargos públicos. E, além disso, repudiávamos que, mesmo a pátria sendo comum a todos, alguns governassem como tiranos, enquanto os demais eram tratados iguais a metecos; e que, ademais, embora fossem cidadãos por nascimento, por lei estivessem despojados da cidadania. [106] Podendo fazer tais censuras às oligarquias e muitas outras além dessas, estabelecemos exatamente a mesma constituição que vigia entre nós também entre os demais. Não vejo porque eu precisaria elogiá-la mais demoradamente, porque posso esclarecê-la brevemente. Pois por meio dela governamos ininterruptamente por setenta anos, sem ter a experiência de tiranias e livres dos bárbaros. Tampouco houve dissensões internas entre nós mesmos, mas levamos a paz a todos os homens.

[107] Convém, por isso, que os homens sensatos sejam muito mais gratos a nós, do que nos venham a censurar por causa das colônias, ${ }^{40}$ que fomos levados a estabelecer nas cidades abandonadas, pela guarda dessas regiões, não por ganância. Prova disso é que tínhamos um território muito pequeno para tão grande número de cidadãos, mas o maior poderio. E possuíamos o dobro de trirremes de todos os demais juntos, [108] sendo capazes de enfrentar uma frota duas vezes maior. No limite inferior da Ática encontra-se a Eubeia, que possuía uma situação estratégica naturalmente vantajosa e que superava todas as outras ilhas em recursos. Tínhamos maior controle sobre ela que sobre nossa própria terra; além disso, sabíamos que, tanto entre os gregos quanto entre os bárbaros, os homens de maior renome são os que, repelindo seus vizinhos, tornam sua vida mais 
opulenta e confortável. Não obstante, nenhuma dessas razões nos induziu a prejudicar os habitantes da ilha, [109] mas somente nós dentre os que detinham grande poder aceitamos viver em piores condições do que aqueles que são acusados de viver como escravos. Ora, se quiséssemos tirar vantagem em excesso de nossa posição, de forma alguma, creio, não desejaríamos a terra dos cionenses, que manifestamente cedemos aos plateus refugiados entre nós, nem teríamos abandonado essa tão grande região, que tornaria a todos nós muito mais prósperos.

[110] Mesmo que tenhamos realizado tão nobres ações e tanto crédito por não haver desejado os bens alheios, ousam nos acusar, aqueles, que tornaram comum participar das decarquias ${ }^{41}$ e vergonhosamente maltrataram sua própria pátria; que fizeram com que parecessem pequenas as injustiças dos predecessores, não deixando nenhum excesso possível aos que mais tarde desejassem superar sua perversidade. Embora alegassem seguir os costumes lacônios, praticavam o contrário e choravam os infortúnios dos mélios enquanto prejudicavam irremediavelmente seus próprios cidadãos. [111] Pois qual crime evitaram? Que ato desonroso ou cruel não cometeram? Eles tinham a maior confiança nos maiores criminosos, adulavam os traidores como se benfeitores fossem e preferiam ser escravos de qualquer um dos hilotas de modo a ultrajar suas próprias terras paternas. Eles honravam mais os assassinos e matadores dos cidadãos do que os próprios genitores. [112] Eles nos puseram todos em tal estado de selvageria que, no passado, em razão da prosperidade então existente, mesmo nos menores infortúnios cada um encontrava muitos que de nós se compadeciam; sob o domínio desses homens, em razão da multidão de males pessoais, deixamos de nos apiedar uns dos outros, pois a ninguém se permitiu ter tanto tempo para si de modo a poder se condoer do outro. [113] Pois quem eles não atingiram? Quem está tão afastado das questões políticas que não tenha sido forçado a cair em desgraças nas quais tais naturezas nos rebaixaram? E também não enrubescem por dispor tão anarquicamente as próprias cidades e por acusar a nossa injustamente, mas ainda ousam, além disso, mencionar os julgamentos públicos e as acusações pessoais ocorridas outrora entre nós, enquanto que eles próprios, em três meses, mataram sem 
julgamento mais homens do que a cidade julgou durante todo o domínio deles. [114] Todos os exílios, todas as leis violadas e mudanças de constituição, e ainda os ultrajes às crianças, as desonras das mulheres e riquezas espoliadas, quem seria capaz de nos descrever? Com exceção de tanta coisa, posso falar de modo geral que facilmente seriam finalizadas com apenas um decreto todas as nossas arbitrariedades, enquanto que se poderiam remediar os massacres e as ilegalidades ocorridas sob o domínio deles.

[115] Ademais, nem a paz presente, nem a autonomia - ausente nas constituições, mas escrita nos tratados - convém preferir ao nosso poder. Pois quem desejaria uma situação como essa, em que piratas controlam os mares; peltastas ${ }^{42}$ ocupam as cidades; [116] em lugar de guerrear contra estrangeiros em defesa de sua terra, dentro das muralhas os cidadãos lutam uns contra os outros; em que há mais cidades capturadas do que antes de se estabelecer a paz; em que, por causa da rapidez das revoluções os que habitam as cidades vivem mais sem ânimo que os exilados (estes, com efeito, temem o futuro, enquanto aqueles sempre têm a esperança do retorno)? [117] Mantêm-se tão distantes da liberdade e da autonomia que certas cidades estão sob o domínio de tiranos, outras são controladas por harmostas, algumas foram devastadas, enquanto os bárbaros se estabeleceram como os senhores de muitas delas. A estes, quando ousaram marchar para a Europa e ser mais ambiciosos do que lhes convinha, [118] nós os enfrentamos com tal disposição que não apenas desistiram de realizar uma campanha contra nós, mas também tiveram que suportar sua própria terra ser devastada. E mesmo navegando pelos mares com mil e duzentas naus, reduzimo-lhes a tamanha humilhação que não conduziram nenhum navio de guerra além de Fasélis, mas permaneceram quietos e esperaram outras oportunidades para atacar, sem confiar no poderio que então tinham. [119] E que essas coisas fossem assim graças à virtude dos nossos antepassados, as desgraças sofridas pela cidade deixam claro: tão logo fomos alijados do comando [archē], começaram [archē] os males para os gregos. ${ }^{43}$ Pois, depois do infortúnio ocorrido no Helesponto, estando outros no comando, os bárbaros venceram nos combates navais, comandaram o mar e apoderaram-se da 
maioria das ilhas. Eles desembarcaram na Lacônia, tomaram de assalto a Citera e navegaram em torno de todo o Peloponeso, causando grandes estragos à região.

[120] Mas, sobretudo, compreender-se-ia a magnitude da mudança se comparássemos os acordos inscritos publicamente ${ }^{44}$ naquela época aos recentemente assinados: ficará evidente, com efeito, que naquele tempo nós limitamos o domínio do rei, ordenamos a alguns de seus súditos o pagamento de taxas e lhe impedimos o acesso ao mar; agora, contudo, é ele quem administra os interesses dos gregos e ordena a cada um deles o que deve fazer, furtando-se apenas de estabelecer sátrapas nas cidades. [121] Pois, exceto isso, o que ainda lhe resta fazer? Não só se tornou senhor da guerra, como também prítane da paz e presidente de todas as questões atuais $?^{45}$ Não navegamos até ele, como se fosse nosso senhorio, para acusarmos uns aos outros? Não o chamamos de "O Grande Rei”, como se tivéssemos nos tornado seus cativos? Nas guerras de uns contra os outros, não colocamos nossas esperanças de salvação nesse homem, o qual teria prazer em destruir a ambos? [122] Tendo tais coisas em mente, é apropriado indignar-se da presente situação, lamentar a perda da nossa hegemonia e censurar os lacedemônios, porque no princípio entraram em guerra para libertar os gregos, mas por fim não só entregaram muitos deles aos bárbaros como escravos, mas também fizeram com que os jônios se afastassem de nossa cidade - da qual saíram para fundar suas colônias e pela qual tantas vezes tinham sido salvos -, apenas para entregá-los aos bárbaros, que têm deles a terra e contra os quais jamais deixaram de guerrear. [123] Outrora os lacedemônios se indignavam quando nós julgávamos apropriado governar alguns dentro dos limites da lei. Mas agora, quando tais populações estão em tal estado de servidão, em nada se preocupam com elas, para as quais não basta recolher impostos e ver suas cidadelas ocupadas pelos inimigos. Mas, além dessas desgraças comuns, em seus corpos sofrem abusos mais terríveis que os nossos servos, pois nenhum de nós maltrata tanto os escravos como os lacedemônios castigam os homens livres. ${ }^{46}$ [124] Mas o maior dos males, sempre que são forçados combater ao lado deles em defesa da própria escravidão, é não só guerrear contra os que estimam ser justa sua liberdade, mas também enfrentar 
perigos tais que, sendo derrotados, serão imediatamente mortos, mas, se vitoriosos, no futuro aumentarão ainda mais sua escravidão.

[125] Quem, além dos lacedemônios, devemos considerar responsáveis por isso, os quais, mesmo com tamanha força, fingem não ver seus próprios aliados sofrer tantos arbitrariedades e o bárbaro construir seu próprio poder com o auxílio do poderio da Grécia? Anteriormente, eles depuseram os tiranos e socorreram a multidão, mas agora estão tão mudados que guerreiam contra as constituições ${ }^{47}$ enquanto estabelecem as monarquias. [126] À cidade dos mantineus, mesmo depois de firmada a paz, eles a arrasaram, ocuparam a Cadmeia dos tebanos e agora sitiam olíntios e fliásios. Mas cooperam com Amintas, rei dos macedônios, com Dionísio, tirano da Sicília, e com o bárbaro, que governa a Ásia, para manter o maior poder possível. [127] Ora, não é absurdo os líderes dos gregos estabelecerem um único homem como senhor de tão grande quantidade de homens - dos quais não é nem um pouco fácil descobrir o número? E eles não permitem que as maiores cidades sejam responsáveis por si mesmas, mas as obrigam a lhes servir ou as envolvem com as maiores calamidades? [128] O mais terrível de tudo, porém, é constantemente ver os que se julgam merecedores de possuir a hegemonia guerrearem diariamente contra os gregos, enquanto mantêm uma eterna aliança com os bárbaros.

[129] E que ninguém suponha que estou de má vontade porque mencionei essas coisas duramente, embora eu tenha anteriormente dito que faria um discurso de conciliação. Pois não foi para caluniar os lacedemônios diante dos demais gregos que desse modo falei a respeito deles, mas para impedir, o quanto o meu discurso for capaz, que eles mantenham tal resolução. [130] E não é possível afastar dos erros nem persuadir a desejar outras atividades, se não se censurar com veemência as presentes ações: deve-se considerar que faz acusações quem fala para prejudicar, mas admoesta quem repreende para beneficiar, já que não se deve supor ser semelhante o discurso, se não for pronunciado com a mesma resolução. 
[131] Pois podemos fazer-lhes também esta censura: que, para o benefício de sua própria cidade, forçaram os povos vizinhos a serem seus hilotas, ${ }^{48}$ mas não providenciam nada semelhante para a união dos aliados, embora lhes fosse possível, se se reconciliassem conosco, tornar todos os bárbaros periecos ${ }^{49}$ de toda a Grécia. [132] Ora, os que pensam alto por natureza, e não pelo acaso, devem empreender ações desse tipo, em lugar de cobrar impostos dos habitantes das ilhas. ${ }^{50}$ Eles são dignos de nossa compaixão, já que os vemos serem forçados, por causa da escassez de terra, a cultivar áreas montanhosas, enquanto os que vivem no continente deixam a maior parte de seu território abandonada, pois têm terra em abundância, obtendo, no entanto, das que cultivam, enorme riqueza. [133] Creio que, se homens vindo de outros lugares se tornassem espectadores dos fatos presentes, eles declarariam como culpados de grande loucura tanto um como outro, que nos arriscamos por pequenas coisas, sendo possível sem medo conquistar muitas outras, e que destruímos nossa própria região, negligenciando colher os frutos da Ásia. [134] Enquanto não há nada mais vantajoso ao grande rei do que investigar meios para nunca cessarmos nossas guerras mútuas, nós estamos tão longe de frustrarmos uma de suas ações ou de causar revoltas que tentamos auxiliá-lo a pôr fim até mesmo nos tumultos proporcionados pelo acaso, que permitimos que, dos dois exércitos que estão no Chipre, ele utilize um enquanto sitia o outro, ainda que ambos pertençam à Grécia. [135] Pois os que se insurgiram em Chipre não só mantêm boas relações conosco e se colocam sob a proteção dos lacedemônios, como também o melhor contingente das tropas que fazem campanha com Tiribazo e da infantaria também têm vindo desses lugares e a maior parte da frota tem navegado da Jônia. Eles, que prefeririam saquear juntos a Ásia a se arriscar uns contra os outros por questões de pouco valor. [136] A isso nós não damos nenhuma atenção, mas disputamos as Cíclades, enquanto tão numerosas cidades e tão grandiosas forças temos despreocupadamente entregue ao bárbaro. Assim, a umas ele possui, algumas está prestes a tomar e a outras ele cobiça. Enfim, com razão ele despreza todos nós, [137] pois ele tem realizado o que nenhum dos seus ancestrais foi capaz, porque tanto nós quanto os lacedemônios reconhecemos que 
a Ásia pertence ao rei, e, quanto às cidades gregas, de forma tão decisiva delas se apoderou que destruiu umas enquanto em outras construiu fortalezas. E tudo isso é resultado da nossa estupidez, não do poder desse homem.

[138] Contudo, alguns admiram a grandeza das façanhas do rei e dizem que ele é difícil de ser vencido, contando como provocou muitas vicissitudes para os gregos; em minha opinião, porém, quem fala essas coisas não inibe, mas acelera a campanha contra o bárbaro. Pois, se é verdade que ele será um oponente difícil mesmo quando nós estivermos unidos e ele próprio enfrentar tumultos, sem dúvida deve-se muito mais temer o momento em que os interesses dos bárbaros se acertarem e eles tiverem um só objetivo, mas nós, como agora, formos inimigos uns dos outros. [139] Mas, ainda que esses homens corroborem o que eu disse, nem assim eles discernem com exatidão o poder do rei. Se, com efeito, tivessem demonstrado que, alguma vez no passado, ele superou simultaneamente as duas cidades, seria razoável que também agora tentassem nos amedrontar; se tal fato, porém, não aconteceu, mas que ele tenha realizado façanhas mais gloriosas porque aliou-se a um dos lados quando nós e os lacedemônios tínhamos igual poder, isso não prova em nada sua força. Pois amiúde nessas oportunidades constantemente pequenos poderes exercem grande e determinante peso. Assim, poderíamos citar o caso de Quios, já que a qualquer um dos dois com os quais eles quisessem se aliar, seriam estes os mais poderossos no mar. ${ }^{51}$

[140] Mas, entretanto, não é correto examinar o poder do rei a partir que obteve ao se aliar com uma ou outra cidade, mas das batalhas ele travou com suas próprias forças. Em primeiro lugar, quando o Egito se rebelou, o que conseguiu fazer contra seus habitantes? Não enviou para essa guerra os mais renomados entre os persas, Abrocoma, Titrauste e Fanarbazo? Esses, depois de resistirem três anos e sofrerem mais males do que causavam aos inimigos, não acabaram por se retirar de uma forma tão vergonhosa que os insurgentes de modo algum se contentaram com a liberdade, mas imediatamente procuraram conquistar os vizinhos? [141] Em seguida, combateu contra Evágoras, ${ }^{52}$ que governa uma única cidade e que, de acordo com os tratados, a ele se rendeu. 
Esse, mesmo habitando em uma ilha, fora derrotado no mar; ele tem apenas três mil peltastas para proteger seu território. Não obstante, o rei não conseguiu superar em batalha tão diminuto poder, mas já perdeu seis anos tentando vencê-lo. E, se devemos tomar como testemunha as ações futuras a a partir das passadas, é de se esperar que outro se insurja antes que Evágoras seja forçado pelo cerco a se render: tal é a lentidão inerente às ações do rei. [142] E na guerra em torno de Rodes, não apenas contou com a benevolência dos aliados dos lacedemônios, descontentes com a severidade da constituição, mas também recebeu de nós a tripulação para suas naus, tendo como general Cônon, que era o mais cuidadoso dos estrategos, o de maior confiança para os gregos e o mais experiente nos perigos da guerra. Mas, mesmo tendo encontrado tal homem como companheiro de batalha, ele permitiu que por três anos a frota, posta frente ao perigo para defender toda a Ásia, fosse cercada por apenas cem trirremes; e durante quinze meses privou os soldados de seu pagamento, de forma que, se dependesse dele, a frota teria debandado muitas vezes. Por causa do perigo iminente e graças à aliança firmada com Corinto, porém, saíram-se vitoriosos em um difícil combate no mar.

[143] Eis as ações mais esplêndidas e dignas de um rei que esse homem realizou, das quais não param nunca de falar os que desejam engrandecer os feitos dos bárbaros. De modo que ninguém poderia dizer que, a seu ver, eu não me sirvo de exemplos injustamente, nem que eu perco tempo com seus pequenos sucessos, deixando de lado suas mais importantes conquistas. [144] Pois, para escapar a essa acusação, narrei os mais nobres dos seus feitos, sem esquecer que Dercílidas, com mil hoplitas, conquistou Eólis; que Drácon, após ter se apoderado de Atarneu e ter reunido três mil peltastas, devastou a planície Mísia; que Tíbron, tendo transportado um pouco mais do que esses, arrasou toda a Lídia; e que Agesilau, usando o exército de Ciro, ${ }^{53}$ esteve perto de conquistar o território além do Hális. ${ }^{54}$ [145] Ademais, nem a tropa que circunda o rei, nem a coragem dos persas merece ser temida: com efeito, foi claramente demonstrado pelos que marcharam com Ciro que eles não são melhores que os que vivem junto ao mar. A todas as outras batalhas, com efeito, em que 
foram derrotados, eu deixo de lado e admito que eles estavam em dissensão interna e que não desejavam ardorosamente se arriscar contra o irmão do rei.

[146] Mas, depois que Ciro morreu, reuniram-se todos os que governavam a Ásia e nessas circunstâncias favoráveis guerrearam de forma tão vergonhosa que não restou nenhum argumento aos que costumam elogiar a coragem dos persas. Pois enfrentaram seis mil gregos, ${ }^{55}$ escolhidos não por sua distinção, mas que, por causa da pobreza, não tinham condições de viver nas próprias cidades. Ademais, desconheciam o território, não dispunham de aliados, haviam sido traídos pelos que com eles marchavam e perderam o estratego ao qual seguiam. [147] Os persas foram tão inferiores a eles que o rei, embaraçado pelas presentes circunstâncias e desprezando seu próprio poder, ousou prender os comandantes dos mercenários, mesmo estando eles sob a proteção de um pacto. Ele pensava que, realizando um ultraje, ${ }^{56}$ colocaria o exército em desordem, e preferiu cometer uma falta contra os deuses a lutar às claras contra aqueles homens. [148] Falhando em sua trama, já que os soldados permaneceram juntos e suportaram nobremente o infortúnio. O rei então enviou Tissaferne e os cavaleiros ao mesmo tempo em que aqueles homens partiam, mas, a despeito das tramoias dos persas, seguiram como se tivessem sido escoltados, temendo sobretudo as regiões desabitadas, mas considerando o maior dos bens se encontravam o maior número possível de inimigos. [149] Em resumo: aqueles homens, que não vieram para saquear nem para tomar um vilarejo, mas para guerrear contra o próprio rei, voltaram em maior segurança do que os embaixadores enviados amigavelmente até ele.

Julgo, assim, que em absolutamente todos os lugares a moleza dos persas tem se mostrado; na costa da Ásia, com efeito, têm se revelado inferiores em toda batalha e, por terem adentrado na Europa, foram punidos, - uns foram miseravelmente destruídos; os outros, salvaram-se de uma maneira desonrosa -, e, por fim, tornaram-se motivo de riso às portas do próprio palácio real.

[150] E nenhuma dessas coisas aconteceu sem razão, mas tudo terminou como esperado, pois é impossível que homens assim criados e governados partilhem de alguma virtude nem ergam um 
troféu sobre seus inimigos. Pois como se poderia produzir um estratego habilidoso ou um bom soldado em suas instituições, cuja maior parte é uma multidão desordenada e inexperiente dos perigos, imprestáveis para o combate e melhor educada para a escravidão do que os nossos escravos domésticos?

[151] Os de maior reputação entre eles, sem exceção, nunca viveram em igualdade nem como cidadãos, mas passaram todo o tempo sendo arrogantes com uns, mas escravos de outros, de modo que a natureza humana pode ser completamente corrompida, aos corpos por meio da riqueza tornando efeminados; tendo as almas, por meio do governo monárquico, submissas e amedrontadas. Perfilados em frente aos próprios palácios, prostram-se aos pés do rei e praticam todo tipo de humilhações. E obedecem-se a um simples mortal, dirigindo-se a ele como a uma divindade, mostrando maior desprezo pelos deuses que pelos homens. [152] Consequentemente, deles os que descem ao mar, que eles chamam de sátrapas, ${ }^{57}$ não desonram a educação de lá, mas permanecem nesses mesmos hábitos, não sendo confiáveis para os amigos e agindo de forma covarde para com os inimigos. Vivem de forma ora humilde, ora soberba, desprezando os aliados enquanto servem aos inimigos. [153] Ao exército de Agesilau, de fato, mantiveram às próprias custas durante oito meses, mas pelo dobro desse período privaram de pagamento os que se arriscavam por eles. Distribuíram cem talentos aos que tomaram Cístene, mas oprimiram mais aos seus aliados na campanha contra Chipre do que os prisioneiros. [154] Brevemente, não entrando em detalhes, mas de modo geral, quem que contra eles lutou não partiu após ter sucesso? Quem sob seu comando não terminou a vida ultrajado? A Cônon, ${ }^{58}$ que guerreou em defesa da Ásia e pôs fim ao domínio dos lacedemônios, não ousaram prender e condenar à morte? A Temístocles, porém, que pela Grécia os derrotou no mar, não julgaram digno das maiores recompensas $?^{59}$

[155] Ora, como se deve desejar a amizade de tais homens, que castigam os benfeitores e tão abertamente adulam os que lhes prejudicam? Contra qual de nós eles não têm praticado o mal? Alguma vez deixaram de conspirar contra os gregos? Qual de nossas coisas não lhes é odiosa, a 
eles, que, na guerra precedente, ousaram saquear e incendiar os santuários e os templos dos deuses? [156] Por isto os jônios também merecem ser louvados: depois que seus templos foram incendiados, lançaram imprecações a quem quisesse transportá-los a outro lugar ou reconstruí-los tal como eram. ${ }^{60}$ Fizeram isso não por carecerem de meios para restaurá-los, mas para deixar uma lembrança aos descendentes da impiedade dos bárbaros e para que ninguém confiasse nos que ousam cometer tanta insolência contra os santuários dos deuses, ${ }^{61}$ mas também a fim de que seus filhos se protegessem e os temessem, ao perceber que os persas guerrearam não somente contra os nossos corpos, mas também contra as oferendas votivas dos templos. [157] E posso também relatar muitas coisas semelhantes a respeito de nossos cidadãos. Com efeito, tão logo se reconciliam com todos os outros contra quem guerrearam, eles esquecem as inimizades do passado; aos asiáticos, por outro lado, não são gratos nem mesmo quando recebem um favor, tão inesquecível é sua ira contra eles. E não somente os nossos pais condenaram muitos à morte por medismo, mas, mesmo agora, nas assembleias, os cidadãos fazem imprecações antes de ocupar-se de qualquer outro assunto, se algum deles pretende negociar a paz com os persas. E na iniciação aos mistérios, os Eumolpidas e os Cérices, por causa de seu ódio por eles, prescrevem que mesmo os demais bárbaros sejam afastados das cerimônias sagradas, como fazem com os assassinos. ${ }^{62}$

[158] Temos uma natureza tão hostil a esses homens que nosso maior prazer é passar o tempo ouvindo os mitos de Troia e da Pérsia, que nos permitem conhecer as desgraças por eles sofridas. Qualquer um notaria que, enquanto se compuseram hinos sobre a guerra contra os bárbaros, cantos fúnebres $^{63}$ nos foram feitos sobre a guerra contra os gregos, os primeiros sendo cantados nas celebrações, os demais lembrados por nós nos infortúnios. [159] Penso que mesmo a poesia de Homero ganhou maior reputação porque elogiou dignamente os que guerrearam contra os bárbaros. Por isto, os nossos ancestrais quiseram honrar a sua arte nas competições musicais e na educação dos mais jovens, para que, ao escutarmos muitas vezes seus versos, aprendamos bem a longa 
inimizade que temos contra aqueles homens, e, emulando a virtude dos que fizeram campanha contra Troia, desejemos realizar as mesmas façanhas que aqueles homens.

[160] Assim, julgo haver muitas coisas que nos exortam levam a combater contra os bárbaros, mas acima de tudo a presente oportunidade, de que não há nada mais evidente: não podemos deixála escapar. Com efeito, é vergonhoso não aproveitar-se dela quando se apresenta, mas lembrá-la depois, quando já passou. Pois o que mais desejaríamos que acontecesse em nosso favor, que pretendemos guerrear contra o rei, além das vantagens de que ora dispomos? [161] Não se revoltaram contra ele o Egito e o Chipre? Não foram a Fenícia e a Síria arrasadas pela guerra? Tiro, de que ele tanto se orgulhava, não foi capturada por seus inimigos? Das cidades da Cilícia, nossos aliados comandam a maioria. E jamais os persas conquistaram a Lícia. [162] Hecatomno, sátrapa da Cária, já há muito tempo, em verdade, rebelou-se, e admitirá isso quando nós quisermos; de Cnido até Cinope, gregos habitam a costa da Ásia, e a eles não é necessário persuadir, apenas não impedilos de guerrear. Dispondo de tais fortificações e havendo tantas guerras pela Ásia, há ainda necessidade de examinar em muitos detalhes o que há de acontecer? Pois, tendo já sido derrotados por pequenos grupos, está claro o que lhes aconteceria se fossem forçados a guerrear contra todos nós.

[163] Essa é a situação atual. Se o bárbaro controlasse com maior firmeza as cidades próximas ao mar, se nelas estabelecesse maiores guarnições do que agora, provavelmente as ilhas próximas ao continente, como Rodes, Samos e Quios, prostrar-se-iam ante os sucessos daquele homem; mas, se nós nos apoderarmos delas primeiro, é razoável que os que habitam a Lídia, a Frígia e o resto do interior da Ásia fiquem sob o controle dos que lá fizessem sua base de operações. [164] Por isso precisamos nos apressar e não perder tempo, para que não soframos o mesmo que os nossos pais. Pois eles foram forçados a se arriscar em pequeno número contra uma grande multidão, porque foram mais lentos que os bárbaros e abandonaram alguns de seus aliados, sendo que poderiam, caso tivessem atravessado antes para o continente, ter submetido um a um cada povo da 
Ásia. [165] Pois está provado que, sempre que se combate contra homens reunidos de muitos lugares diferentes, não se deve esperar que eles avancem para perto de nós, mas investir contra eles enquanto ainda se encontram dispersos. Aqueles homens, pois, corrigiram todos seus erros anteriores lançando-se nas maiores batalhas; nós, por outro lado, se formos prudentes, desde o início tomaremos precauções e tentaremos ser os primeiros a estabelecer um exército na Lídia e na Jônia, [166] sabendo que também o rei governa os habitantes do continente não por que estes queiram, mas por ele ter em torno de si um poder maior que cada um deles separadamente detém. Nós, quando trouxermos uma força maior do que essa - o que faríamos com facilidade, se quiséssemos -, em segurança desfrutaremos de toda a Ásia. E é muito mais nobre guerrear contra aquele homem por seu reino do que nos confrontarmos pela hegemonia.

[167] Deve-se realizar a campanha contra a Ásia na presente geração, para que estes que receberam sua parte nas desgraças também desfrutem dos benefícios e não passem toda sua vida no infortúnio. Pois lhes basta o tempo que passou, no qual muitas coisas terríveis aconteceram. A natureza do homem originalmente está sujeita a muitos males, mas só nós temos encontrado mais do que o necessário, [168] já que fizemos guerras e dissensões contra nós mesmos, de modo que uns perdem a vida de forma ilegal em suas próprias cidades, enquanto outros vagam com a mulher e os filhos por terra estrangeira e muitos, sendo forçados pela falta das necessidades diárias a servirem como mercenários, morrem ao lutar contra os amigos em favor dos inimigos. Dessas coisas ninguém nunca se indignou, mas consideram apropriado chorar pelas desgraças compostas pelos poetas. Presenciando, porém, os verdadeiros sofrimentos, as muitas e terríveis calamidades produzidas pela guerra, estão tão longe de sentir piedade que tiram maior prazer dos males dos outros do que de seus bens particulares. [169] Mas talvez muitos rissem também da minha simplicidade, se eu lamentasse os infortúnios dos homens nessa ocasião em que a Itália foi devastada; a Sicília, escravizada; tantas cidades foram entregues aos bárbaros; e a restante parte dos gregos se encontra em grande perigo. 
[170] Eu me admiro com os que detêm o poder nas cidades, se creem lhes convir ser orgulhosos, quando nunca foram capazes nem de falar nem de refletir nada sobre assuntos tão importantes. Pois eles deveriam, se realmente fossem dignos de sua presente reputação, propor e aconselhar sobre a guerra contra os bárbaros, ignorando todo o resto. [171] Com efeito, talvez conseguissem realizar algo, e, mesmo se eles desistissem antes de alcançar algum resultado, ao menos deixar-nos-iam seus discursos como espécie de oráculos para o futuro. ${ }^{64}$ Mas os de maior reputação ocupam-se de coisas pequenas, enquanto têm deixado a nós, que renunciamos à vida pública, aconselhar sobre tão grandes assuntos. [172] Não obstante, quanto mais pusilânimes forem os nossos líderes, tanto mais veementemente o resto de nós deve investigar como nos livraremos do presente ódio. Agora, de fato, em vão firmamos acordos de paz, pois não pomos um fim às nossas guerras, mas as retardamos e aguardamos a ocasião na qual poderemos causar um mal irreparável aos outros.

[173] Depois de termos renunciado a essas conspirações, devemos empreender aquelas ações que nos darão maior segurança para habitar as cidades e teremos maior confiança em nós mesmos. É simples e fácil a explicação disso: nem é possível manter uma paz definitiva sem que guerreemos em comum contra os bárbaros, nem os gregos entrarem em acordo antes de nos beneficiarmos dos mesmos homens contra quem guerreamos. [174] Depois que tais coisas tenham se produzido e que tenha chegado ao fim a dificuldade de nossas vidas, a qual destrói as amizades, leva as famílias ao ódio e põe todos os homens em guerra e em dissensões internas, é impossível que não entremos em acordo e não sejamos verdadeiramente benevolentes com nós mesmos. Por isso é imperativo transpor o quanto antes a guerra daqui para o continente, pois assim poderíamos desfrutar da única vantagem das nossas guerras mútuas, se decidíssemos usar experiência nelas adquirida para lutar contra os bárbaros.

[175] Mas, com efeito, talvez devamos nos restringir por causa do tratado, e não nos precipitar e fazer a campanha demasiado rápido. Por causa desses acordos, as cidades que foram 
libertadas são gratas ao rei, como se graças a ele tivessem obtido essa autonomia, enquanto as que foram entregues aos bárbaros acusam em primeiro lugar os lacedemônios, e, depois desses, também todos os demais que partilham da paz, como se por eles tivessem sido forçadas à escravidão.

Ora, há alguma razão para não rejeitar esse acordo, que gerou a opinião de que o bárbaro se preocupa com a Grécia e é o guardião da paz, e que alguns de nós a maltratam e fazem-lhe mal? [176] E o mais ridículo de tudo é que respeitamos precisamente as piores condições estipuladas no acordo. Pois as que concedem autonomia às ilhas e às cidades na Europa há muito tempo têm sido violadas e em vão estão escritas em pilares; mas vigoram e todos nós damos autoridade às que nos trazem vergonha e que entregaram muitos dos aliados ao bárbaro, as quais deveríamos anular e não aceitá-las nem mesmo por um único dia, considerando-as como ordens, e não tratados. Pois quem não sabe que os tratados dispõem de forma comum e igual para ambas as partes, enquanto ordens tratam contra a justiça uma delas com inferioridade. [177] Por isso mesmo seria justo acusar os embaixadores que negociaram essa paz, porque, tendo sido enviados pelos gregos, firmaram o tratado no interesse dos bárbaros. Pois, se pensavam que cada um deveria manter seu próprio território, ou estender seu controle para os que foram capturados na guerra, ou dominar os que porventura controlasse à ocasião da paz, deveriam eles ter definido um desses pontos e aplicá-lo igualmente a todos, e assim estabelecer por escrito a respeito dessas questões. [178] A nossa cidade e à dos lacedemônios, porém, não concederam nenhuma honra, mas estabeleceram o bárbaro como o senhor de toda a Ásia, como se tivéssemos guerreado em favor daquele homem ou como se o domínio dos persas se tivesse há muito tempo estabelecido, enquanto fazia pouco que nós fundamos nossas cidade, sendo que apenas recentemente aqueles homens obtiveram essa honra, enquanto nós durante todo o tempo exercermos o poder entre os gregos.

[179] Mas creio que, falando do seguinte modo eu exporei com maior clareza a nossa desonra e a vantagem do bárbaro: toda a terra sob o firmamento foi dividida em duas partes, e uma foi chamada Ásia, a outra, Europa; pelos tratados, o rei tomou a metade dela, como se tivesse 
partilhado a terra com Zeus, e não feito um tratado com homens. [180] E nos obrigou a gravar esse tratado em pilares de pedra e as colocar nos santuários públicos, sendo um troféu muito mais nobre do que os obtidos nas batalhas, pois estes celebram ações pequenas e um único sucesso, enquanto aquelas foram erigidas por causa de toda a guerra e da derrota da Grécia inteira. [181] Por isso devemos nos encolerizar e investigar como nos vingaremos pelo passado e como corrigiremos o futuro. Com efeito, é vergonhoso que, em nossa vida privada, consideremos justo que os bárbaros sejam nossos servos, mas, como um povo, permitamos que tantos aliados sejam seus escravos. Também é vergonhoso que os contemporâneos à guerra de Troia, por causa do rapto de uma única mulher, tenham sido todos tão solidários à ira dos homens lesados que não cessaram de guerrear antes de arrasar a cidade daquele que ousou cometer esse crime, [182] mas nós, quando a Grécia inteira é ultrajada, não nos juntamos para nos vingar, quando nos é possível realizar todas as nossas preces. Pois esta é a única guerra melhor que a paz, pois ela mais se assemelha a um espetáculo que a uma campanha, sendo vantajosa a ambos: tanto aos que desejam viver com tranquilidade quanto aos que querem guerrear, pois uns poderiam desfrutar seus próprios bens em segurança e os outros, tirar grandes riquezas dos estrangeiros.

[183] Pode-se refletir de muitas maneiras diferentes, e chegar-se-ia igualmente à conclusão de que essas ações nos são as mais proveitosas. Pois, vejamos: contra quem devem guerrear os que não cobiçam nenhum ganho, mas aspiram à própria justiça? Não é contra os que no passado fizeram mal à Grécia e hoje conspiram contra ela e durante todo o tempo nos foram assim hostis? [184] A quem é razoável que invejem os que de forma alguma agem como covardes, mas exercem sua coragem com moderação? Não é aos que detêm um poderio maior que os homens devem ter, mas são menos merecedores que os desafortunados entre nós? Contra quem é mais conveniente que se lancem em campanha os que desejam respeitar os deuses ao mesmo tempo em que pensam na própria conveniência? Não é contra os que são nossos adversários por natureza e nossos inimigos ancestrais; que possuem os mais numerosos bens, mas são completamente incapazes de defendê- 
los? Certamente aqueles homens estão sujeitos a essas acusações. [185] E, ademais, tampouco prejudicaremos as cidades reunindo soldados de sua população, o que mais lhes transtornava nas recentes guerras mútuas (creio que serão muito mais raros os que querem ficar do que os que se juntam a essa expedição). Pois quem é tão indolente, ou jovem ou velho, que não desejará participar dessa campanha, comandada pelos atenienses e lacedemônios, reunida em defesa da liberdade dos aliados, enviada por toda a Grécia para vingar-se dos bárbaros?

[186] Quão grande fama, memória e renome devem-se considerar que terão, enquanto viverem, e que deixarão depois de mortos os homens que se distinguem em façanhas como essas? Pois, se os que guerrearam contra Alexandre ${ }^{65}$ e tomaram uma única cidade merecem elogios tão grandes, que tipo de encômios devem-se esperar que obterão os que tiverem conquistado toda a Ásia? Pois qual dos capazes de compor versos ou dos que sabem falar não se esforçará nem filosofará, querendo deixar para todo o sempre uma lembrança tanto de sua própria inteligência quanto da virtude daqueles homens?

[187] Não tenho no presente momento a mesma opinião que no início do discurso. Então, eu pensava que seria capaz de falar à altura dos assuntos; agora, contudo, estou aquém de sua grandiosidade, e me escaparam muitas coisas que pretendi. Sois vós, pois, que deveis me auxiliar a ver quão grande prosperidade poderíamos alcançar, se dirigíssemos a guerra que agora lutamos entre nós contra os povos do continente e se transportássemos a prosperidade da Ásia para a Europa. [188] E vós não deveis ir embora como se fossem simples ouvintes, mas aqueles capazes de agir devem mutuamente exortar-se a tentar reconciliar a nossa cidade e a dos lacedemônios, e os que discutem os discursos devem parar de escrever a respeito da fiança ${ }^{66}$ e acerca das outras futilidades de que agora se ocupam, e tentar competir com este discurso e investigar como falarão melhor do que eu a respeito dos mesmos assuntos, [189] pensando que não convém a homens que fazem grandes promessas perder tempo com coisas pequenas nem falar o que não melhorará a vida 
dos que quer persuadir, mas aquilo cuja realização livrará eles mesmos da presente dificuldade e fará os demais julgarem-nos responsáveis pelos maiores bens.

${ }^{1}$ As Panegírias eram os mais importantes festivais da Grécia antiga. Eram quatro em número (segundo a ordem de importância, respectivamente: Olímpicos, Píticos, Ístmicos e Nemeus), e sua realização se dava de acordo com um intervalo regular de tempo, os jogos em Olímpia e Delfos sendo quadrienais e os demais, bianuais. Esses eventos proporcionavam um ponto de encontro comum a todos que se identificavam como gregos (lembremos que, já naquele tempo, as migrações haviam dispersado os gregos por todo o Mediterrâneo e que a independência política das poleis não os obrigava a ter contato com outros gregos), fornecendo assim uma ocasião para renovar os laços que faziam com considerassem ter uma identidade comum. A importância da Panegírias para o mundo helênico poderia também ser reconhecida pela trégua decretada no momento de sua realização, determinando que não poderia haver nenhum conflito entre gregos durante a realização das festividades. Para maiores detalhes, vd. o segundo capítulo de nosso estudo, p. 40-43. Cabe ainda lembrar que, nos Jogos Olímpicos, as competições estavam reservadas apenas aos atletas, mas, como o próprio Isócrates mais adiante indica (45), nas outras Panegírias - nos Píticos e Nemeus, por exemplo - as competições musicais eram parte essencial da celebração.

${ }^{2}$ Embora as premiações dos festivais fossem apenas simbólicas (como a coroa de louros, concedida aos vencedores dos Jogos Olímpicos), aos atletas vencedores geralmente estavam reservadas grandes honras em suas poleis natais: em Atenas, por exemplo, os vitoriosos nos Jogos Olímpicos podiam fazer refeições no Pritaneu, junto aos membros do conselho (vd. Plat. Apol. 36 d-e). Isócrates, ao decidir iniciar seu discurso com uma crítica aos organizadores das Panegírias e aos atletas, portanto, coloca-se em clara oposição ao esperado, em razão da boa reputação que os atletas gozavam para a maioria das pessoas. Exaltar a superioridade da mente comparando-a com as proezas dos corpos, por outro lado, não era algo original, pois Xenófanes, já no século VI a.C., depois de listar inúmeras atividades presentes nos jogos, declara: 
...melhor que a força

de homens ou cavalos é nossa sabedoria.

Ora, muito sem seriedade se reflete sobre isso, tampouco é justo

preferir a força à boa sabedoria.

Pois, mesmo que houvesse, em meio ao povo, um bom pugilista,

ou se fosse bom no pentatlo ou na luta,

nem mesmo se tivesse pés velozes - que é a coisa que se mais preza -,

nem todos os esforços dos homens de vigor nas competições;

em razão deles, uma polis não seria mais bem regrada.

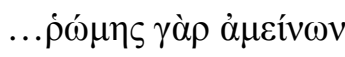

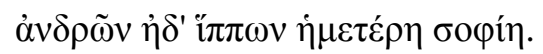

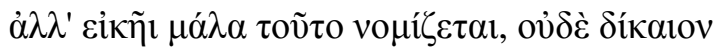

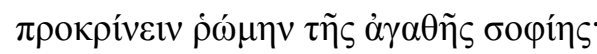

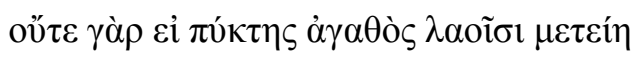

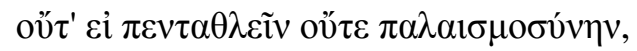

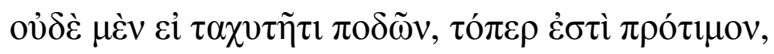

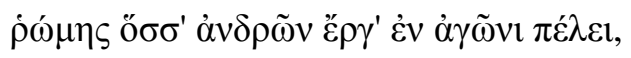

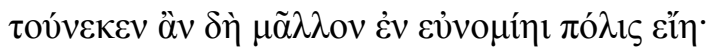

(fr. 2. Diels; Kranz. Die Fragmente der Vorsokratiker, v. 11-19)

Tal como no segundo parágrafo do Panegírico, a força física do corpo é comparada a propriedade exclusiva da alma - a sabedoria (sophiē, em Xenófanes) tendo como critério a utilidade dessas duas para as outras pessoas. Nesse sentido, o fragmento de Xenófanes é ainda mais claro que Isócrates, ao estabelecer o benefício político da sabedoria, que, diferente da força física, pode ser aproveitada por toda a polis. Sendo assim, o Sócrates platônico, em sua defesa diante do tribunal, defende que a pena que deveria ser-lhe imputada era jantar no Pritaneu: “O que então é apropriado a um benfeitor pobre e necessitado de ócio ao exortá-los? Não há nada mais apropriado, cidadãos atenienses, a tal homem que cear no pritaneu, muito mais do que se alguém dentre vós tivesse vencido em Olímpia 
com um cavalo, com a parelha ou com a quadriga: pois este vos faz parecer serdes felizes, enquanto

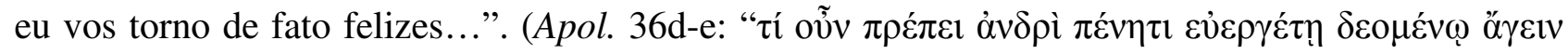

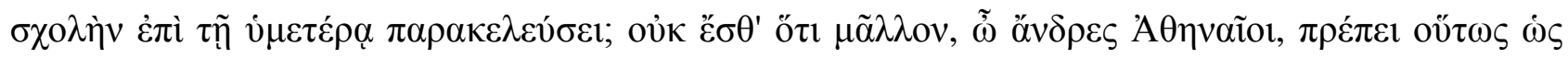

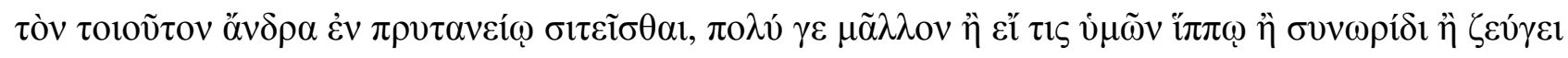

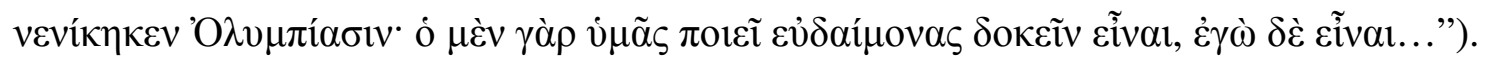

${ }^{3}$ Entre os antecessores referidos por Isócrates, certamente podem-se incluir Górgias e Lísias, ambos autores de discursos tratando das mesmas questões que o Panegírico (discurso n. 33 do corpus lysiacum e fragmentos 7, 8, 8a em DK), embora o emprego de um termo genérico dê maior amplitude às críticas do discurso, relacionando-as a um número maior de opositores. Essa não era, no entanto, uma estratégia original de Isócrates, pois já no Olímpico de Lísias (3) aparece o desafio aos rivais, também denominados como sofistas, evidenciando o caráter tópico desse recurso.

Definir "sofista", por outro lado, é uma tarefa difícil, devido à grande abrangência que o termo adquiria na língua grega antiga: o uso mais antigo de uma palavra desse mesmo grupo semântico acontece em Homero (Il. XV, 412), onde sophia se refere à carpintaria. Especificamente quanto a sophos, Chantraine, em seu dicionário etimológico da língua grega, estabelece a seguinte definição: "qui sait, qui maîtrise un art ou une technique" (1977, p. 1030). Ademais, o dicionário Lidell \& Scott, no respectivo verbete, lista como primeira acepção para o termo "skilled in any handicraft or art, clever", e dá como exemplos o condutor de carruagens (Pínd. Pít. V, 115) e o piloto de uma nau (Ésq. Supl. 770), embora assinale que, nesse sentido, o termo sophos é principalmente usado pelos poetas para designarem sua própria atividade. A adição do sufixo de agente - $(i)$ stês reforçava a noção de um exercício profissional especializado, e, embora o termo sophistēs pudesse abranger uma grande variedade de profissionais (adivinhos [Heród. II, 49], mas também músicos [Aristóf. Rãs 314] e poetas [Pínd. Ístm. V, 28]), no final do séc. V a.C., ele é utilizado sobretudo para qualificar um certo tipo de professor. 
Esse uso é mais claro, no séc. IV a.C., nos diálogos de Platão, em que o termo "sofista" é geralmente empregado para identificar os praticantes de uma forma de educação antagônica à “filosofia", atribuída ao usual protagonista platônico Sócrates. O diálogo Protágoras, por exemplo, ao retratar aquele que é considerado um dos maiores expoentes da sofística, nos auxilia a entender que tipo de profissional era aquele classificado por Platão como "sofista": após retratar a educação ateniense desse período (325c5-326c6), o texto situa os sofistas como uma etapa adicional à trajetória tradicionalmente seguida pelos jovens atenienses. O sofista então visaria, segundo nos informa Protágoras, à preparação para a vida pública (o personagem diz ensinar uma politike technē), a qual os jovens que o frequentavam estariam em idade de iniciar. É importante salientar que esse tipo de educação política a cargo dos sofistas pretendia ser um complemento ao ensino consagrado em Atenas, cuja principal finalidade era não o conhecimento especializado, mas a formação moral do menino: o gramatista ensina a escrita e a leitura para que seus alunos possam ler e decorar os poemas de Homero e Hesíodo, narrando os feitos dos grandes heróis do passado, os quais eles devem imitar; da mesma forma, a preocupação do citaredo não é formar instrumentistas, mas inscrever-lhes a harmonia na alma, para que seus pensamentos possam ser tão ordeiros quanto as melodias que eles aprendem; o pedotriba, por fim, deveria fornecer-lhes corpos fortes o bastante para obedecer os comandos da alma.

A educação oferecida pelos sofistas, pois, seria, a seguir o que dela diz Platão, o último passo necessário para o ingresso na vida pública. Por essa razão os sofistas estavam sujeitos à desconfiança dos cidadãos atenienses, pois, mesmo oferecendo um tipo de ensino que seria um complemento ao modelo tradicional de educação da polis, pretendiam formar seus cidadãos.

A despeito dessas generalizações, no entanto, a classificação de "sofista" poderia ser atribuída a muitos homens. Sócrates, defensor da filosofia nos diálogos de Platão, é chamado de sofista por Aristófanes na comédia As Nuvens. 
Devemos, por último, notar que Isócrates, embora designasse seus rivais como "sofistas", não imprimia no termo um significado completamente negativo (como no Contra os Sofistas), uma vez que, em outras ocasiões, ele referia a si mesmo como sofista (na Antídose 155-58, por exemplo).

${ }^{4}$ No texto grego, aqui e no parágrafo 6, a palavra "discurso" (“logos”) é uma referência de Isócrates aos discursos anteriores que também trataram da concórdia entre os gregos e da guerra contra os bárbaros nas Panegírias, como os Olímpicos de Górgias e Lísias.

${ }^{5}$ Sobre os usos de "filosofia" e seus derivados, vd. a nota abaixo.

${ }^{6}$ A palavra "filosofia” não designava, no início do séc. IV a.C., uma disciplina estabelecida, sendo usada indiferentemente para nomear variadas práticas pedagógicas. A partir desse uso mais geral, Isócrates tentou se apropriar do termo para designar o ensino por ele desenvolvido em sua escola, embora Platão, que se utilizou do mesmo expediente, tenha tido maior sucesso e, a partir daí, “filosofia" esteja invariavelmente ligada à concepção platônica de filosofia.

${ }^{7} \mathrm{O}$ termo aqui utilizado por Isócrates, epideiktikōs, é um hapax legomenon, isto é, termo de ocorrência única na literatura grega. O termo "epidítico" (que pode ser traduzido como “demonstrativo") será utilizado por Aristóteles para designar um dos gêneros discursivos em sua sistematização da retórica (1358a36-b7), o dos discursos de elogio ou vitupério. Para Isócrates, porém, "epidítico" estava relacionado às qualidades da elocução, as quais o autor considera necessárias para tratar de assuntos importantes, como aqueles de relevância para a Grécia.

${ }^{8} \mathrm{Na}$ Atenas do período clássico, os oradores se apresentavam para grandes audiências, não somente nas assembleias (que reuniam milhares de pessoas), mas também nos tribunais, pois os júris (que acumulavam a função de juiz e a de jurado) eram então compostos por mais de quinhentos membros. Para alcançar sucesso em tais ocasiões, era necessário, pois, controlar grandes multidões, e para isso foram desenvolvidas técnicas especiais, como acalmar uma audiência inquieta no início de sua fala (Plat. Eutid. 290 a; Arist. Ret. III 14, 7), e torná-la favorável ao orador, mostrando sua 
humildade ao pedir desculpas e dizer que não houve tempo de preparar o discurso (vd. Lísias Epit. 1-2, discurso certamente visado pelas críticas que Isócrates aqui faz).

${ }^{9}$ Segundo comentadores antigos, a redação do Panegírico prolongou-se por dez anos (Timeu, citado no Subl. 4, 2; Subl. 4, 2; Dion. Hal. Comp. 25; Quint. X, 4, 4; Vida 837f - neste último testemunho, embora o autor anônimo aceite a opinião geral, ele menciona que alguns comentadores consideram que o discurso levou quinze anos para ficar pronto; há ainda Plutarco, que, na Glória dos atenienses 350e 9-10, fala, sem precisar um número exato, de um período de quase três olimpíadas). É bastante provável, porém, que essas datas sejam apenas tentativas tardias de explicar a menção de Isócrates ao período de composição do discurso, sem se fundarem, porém, em qualquer evidência que as confirme (Masaracchia: 1995, p. 50: "Si tratta certamente di dati chi non hanno fundamento fuori il desiderio di fornire un numero iperbolicamente indicativo”).

${ }^{10}$ Isócrates usa o termo "bárbaro" para se referir pejorativamente ao rei persa.

${ }^{11} \mathrm{O}$ termo politeia, aparecendo aqui em sua usual tradução - “constituição" -, designava a forma de governo pelas quais as poleis eram administradas. Aristóteles entende a politeia como "a organização da polis e de suas diferentes posições públicas e, sobretudo, da autoridade total. Pois os

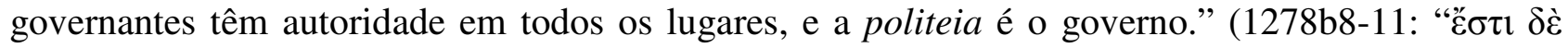

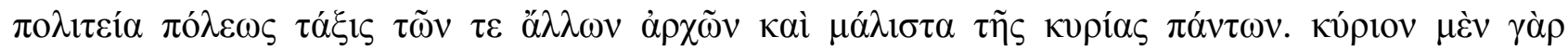

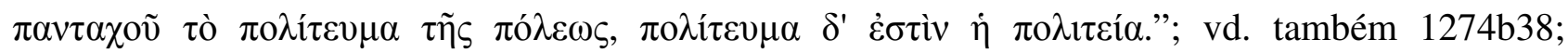
1289b15-18). Em muitos Estados modernos, essa organização política da politeia está representada por uma lei específica, denominada "constituição", que define os princípios de governo e as tarefas dos participantes na administração pública, mas, na antiguidade, as funções da politeia não estavam determinadas por um único dispositivo legal. Além desse sentido mais amplo, a palavra politeia também era utilizada para nomear formas de governo particulares, como acontece no Panegírico, quando Isócrates chamada a democracia como politeia (vd. o parágrafo 125 e a respectiva nota). 
$\overline{{ }^{12} \text { No original, "polis" (plural: poleis). Do século VIII a.C. até a conquista da Grécia por Alexandre }}$ em 323 a.C., os gregos não estavam submetidos à autoridade de um estado soberano, mas dividiamse em unidades políticas autônomas, as poleis. Polis, portanto, indicava uma unidade política determinada no mundo grego, cuja administração estava algumas vezes centrada em um espaço urbano (astu: para detalhes sobre a diferença entre polis e astu, vd. o parágrafo 81 do Panegírico e a respectiva nota), mas que ultrapassava seus limites geográficos e englobava a região a seu redor e mesmo pequenas vilas e outras cidades (o caso ateniense é exemplar nesse ponto, uma vez que a polis recobria não somente Atenas, mas as áreas adjacentes e pequenas cidades, como Falero e Eleûsis, além do Pireu, região portuária da Ática).

Por conveniência, vertemos esse termo por sua usual tradução nas línguas modernas, "cidade" (preferível, tendo em vista as demais possibilidades, "Estado", "Cidade-Estado"), embora essa palavra não cubra todos os significados do original grego.

${ }^{13}$ No Panegírico, esta é a única ocorrência de "hegemonia" no plural, a indicar o comando conjunto de Atenas e Esparta, sendo que a primeira dominaria o mar, enquanto a segunda lideraria as tropas gregas em terra. Deve-se notar que, logo em seguida (21), o termo é usado no singular, índice da mudança de significado, que passa a designar não mais a liderança compartilhada entre as duas poleis, mas o direito ateniense de comandar a ofensiva marítima na campanha grega contra a Ásia. ${ }^{14}$ Os mitos atribuem a fundação de Atenas a heróis que teriam nascido da própria terra ática. $\mathrm{O}$ mais importante deles, Erecteu, ao qual estava dedicado um templo na acrópole ateniense, é citado na Ilíada: (“...o magnânimo Erecteu, ao qual outrora alimentou Atena, filha de Zeus, quando o

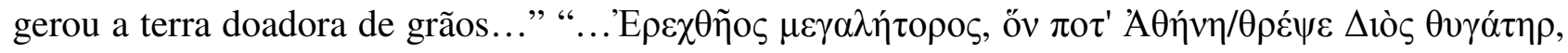

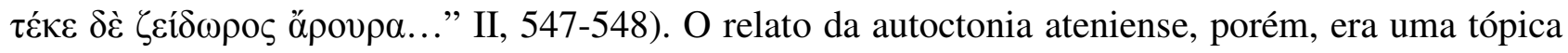
do epitáfio ateniense, um gênero de discursos estritamente relacionado com a democracia. Por isso, a autoctonia, nesses discursos, aparece relacionado não a uma figura fundadora (o que estabeleceria uma ordem hierárquica dentro da polis, típica das oligarquias, onde os cargos de comando estão 
reservados aos descendentes dos fundadores), mas com o povo ateniense, que partilha todo ele da honra de nascer da própria terra da polis em que habitam e não terem se misturado a outros povos. A respeito dos discursos fúnebres, vd. a nota 33 a esta tradução (p. 104).

${ }^{15}$ Korē, "Moça", era o modo usual pelo qual os gregos se referiam à deusa Perséfone, pois contavase que, quando jovem, ela fora raptada por Hades, divindade que governa o mundo dos mortos, para ser sua esposa. Então sua mãe, Deméter, vagou pela Grécia à sua procura, e, na passagem pela Ática, em retribuição pela piedade dos atenienses, ensinou-lhes o cultivo da terra - Deméter é a deusa grega da agricultura - e os ritos iniciáticos, fundando assim os mistérios de Elêusis. A história das errâncias da deusa é narrada em detalhes no Hino Homérico a Deméter.

${ }^{16}$ A Pítia era a sacerdotisa de Apolo em Delfos. A partir da interpretação de suas falas, quando ela estava em transe, eram pronunciados os oráculos (vd., por exemplo, Heród. Hist. VII 140).

$17 \mathrm{Na}$ Grécia antiga, havia o costume de se oferecerem os primeiros frutos da colheita como sacrifício aos deuses (Sóf. Traq. 183; Tuc. Hist. III 58, 4). Ao reservar as primícias, estabelecidas em 1/1200 da colheita do trigo e 1/600 da colheita da cevada, para o festival em Elêusis, os aliados não somente testemunhavam sua devoção à deusa, mas reconheciam o poder de Atenas, que controlava o culto a Deméter. Dessa forma, como o próprio Panegírico dá a entender, após a derrota na guerra do Peloponeso, as contribuições se tornaram mais escassas, consequência da perda da preeminência política de Atenas.

${ }^{18}$ Os atenienses afirmavam que a expansão grega para a costa da Ásia partiu da Ática (Tuc. Hist. I, 2, 12). Assim, os atenienses consideram que os gregos jônios, nome dado aos habitantes dessa região, têm como fundador um ateniense - Íon -, neto de um dos fundadores míticos de Atenas, Erecteu.

19 Possível referência aos sistemas legais estabelecidos por Drácon e Sólon (c. 620 e 590, respectivamente). 
$\overline{{ }^{20} \text { Referência ao mito do julgamento de Orestes, o qual nos é relatado por Ésquilo na tragédia }}$ Eumênides. Aí, o filho de Agamêmnon, após matar sua mãe para puni-la pelo assassinato do pai, é perseguido pelas Erínias, deusas da vingança. Com auxílio de Apolo, que o havia impelido ao matricídio, o herói ganha o direito de ser julgado no Areópago, em Atenas, pela deusa protetora da cidade. A história, portanto, contrapõe duas formas distintas de se punir um crime: uma mais antiga, que, consistindo na retribuição direta pela parte afetada por um agravo, não se distingue da vingança; outra, mediada pela lei e confirmada por um corpo de cidadãos que ouve cada um dos envolvidos e dá chance ao acusado de se defender, fundaria a noção de justiça. Dessa forma, os atenienses justificavam a afirmação de que Atenas havia sido o lugar de nascimento das leis, sendo a primeira polis a estabelecer um código legal e não regrar suas punições de acordo com o sentimento de vingança.

${ }^{21} \mathrm{O}$ Pireu era uma localidade, distante cerca de $8 \mathrm{~km}$ de Atenas, onde se encontrava um grande porto e por onde se realizava o comércio de Atenas com as outras partes da Grécia e com os bárbaros.

${ }^{22}$ As libações aos deuses selavam a trégua temporária entre os estados gregos durante as Panegírias. ${ }^{23}$ É improvável que logoi aqui se refira a "discursos", significado usual do termo no Panegírico, uma vez que não temos notícia da competição de oradores nas Panegírias. Assim, a palavra teria seu sentido mais geral de "fala", designando as competições poéticas, essas sim, atestadas nas Panegírias e demais festivais. Ao incluir logoi em meio a essas competições, porém, Isócrates certamente queria estender a abrangência das Panegírias a sua própria atividade de compositor de discursos, de forma que mantivemos a tradução usual da palavra.

${ }^{24}$ Nos parágrafos 45-46, Isócrates refere-se aos festivais que organizados pelos atenienses, que, por sua grandiosidade, tentavam adquirir o mesmo estatuto entre os gregos que as quatro Panegírias. Entre esses festivais, os mais importantes eram as Grandes Panatenaias, realizadas, como os Jogos Olímpicos e Píticos, quadrienalmente, e as Dionísias Urbanas, que eram anuais. Existiam ainda as 
versões menores desses eventos, as Pequenas Panatenaias e as Dionísias Rurais, que se contavam entre os festivais regionais de Atenas (como as Leneias, por exemplo), voltados para os cidadãos da polis.

25 "Filosofia", como vimos acima (vd. nota 6 a esta tradução, p. 133), ainda não era, no século IV a.C., uma disciplina definida, podendo esse termo ser utilizado em relação a diversos saberes.

${ }^{26} \mathrm{Em}$ toda essa passagem (47-50), Isócrates se vale da ambiguidade da palavra grega logos - que se relacionava tanto com a fala como com o pensamento (o dicionário Lidell \& Scott registra, entre as acepções para o termo, os seguintes significados: "thinking, reasoning"; "reason, as a faculty", mas também "verbal expression or utterance"; vd. a referência, no parágrafo 50, ao "falar e pensar"). Essa ambiguidade revela a concepção que Isócrates tinha de sua atividade ao compor discursos (logos), pois o correto exercício do logos pressupunha não somente o domínio da elocução, mas também do refletir sobre os problemas tratados. Assim, ao estabelecer o logos como próprio aos homens e causa de sua superioridade sobre os outros animais, o autor se utiliza de uma estratégia para valorizar sua atividade (no Nícocles, o autor se serve do mesmo expediente, em uma passagem que ficou conhecida como Hino ao Logos, entre os parágrafos 6-9).

27 A palavra grega technē, da qual deriva technikōs, "artístico", tem conotações diversas que a sua usual tradução moderna "arte" dificilmente deixam perceber: tratava-se de um saber produtivo, voltado a uma área em particular, os discursos, no caso, mas podendo se referir também a diversas outras disciplinas, como a pintura, a escultura, ou ainda a arquitetura e a medicina. Ao mencionar "discursos artísticos", pois, Isócrates refere-se a discursos compostos por homens que adquiriram um domínio dos discursos por meio da educação ("paideia"), ao contrário de um leigo ("idiōtēs"), que o faz apenas segundo sua natureza ("physis"); para maiores detalhes, vd. Contra Sof. 14-15.

${ }^{28}$ A súplica (hiketeia) tinha um estatuto especial na Grécia antiga, estabelecendo uma relação não apenas social, mas também religiosa, pois os pedidos eram mediados pelos deuses, selando um pacto sagrado entre quem faz a súplica e quem a atende. Em razão desse caráter religioso que a 
súplica possuía na antiguidade, estabelece-se um compromisso de gratidão do suplicante para o suplicado que atravessa as gerações, como fica claro nos parágrafos subsequentes do Panegírico, nos quais Isócrates censura os espartanos por não se portarem de maneira adequada com os atenienses, descendentes de seus salvadores.

Além de sua importância do ponto de vista religioso, tal expediente assumia um caráter político, pois, ainda no tempo de Isócrates, uma assembleia era anualmente realizada em Atenas para que se pudessem fazer súplicas à polis (Aristóteles. Constituição dos Atenienses, XLIII, 6).

29 eponeidistōs é um advérbio de modo cuja raiz é encontrada em oneidos - "censura", "reprovação". O uso do termo para designar um fim indesejado para a vida de Eristeu evidencia, portanto, a dimensão social do homem grego, para o qual a posição dentro da polis era um fator determinante para a felicidade.

${ }^{30}$ Esparta contava não com um, mas com dois reis, em razão de ter ela sido fundada pelos dois filhos de Héracles, e, embora os heraclidas tenham deixado uma numerosa descendência, a sucessão real estava restrita a apenas duas famílias: os Euripontidas e os Agiadas (Plut. Lis. 24, 3).

31 "Virtude" geralmente é usada para traduzir a palavra grega aretē, indicando a excelência em qualquer tipo de atividade, como fica claro com Homero, que utiliza o termo para designar, "a

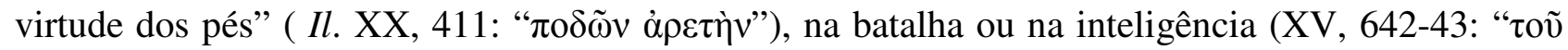

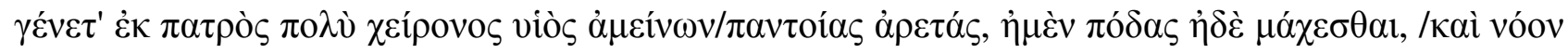

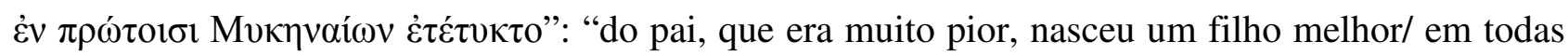
as virtudes, nos pés, no combater e na inteligência estava entre os primeiros dos micênicos"). Segundo Chantraine, somente mais tarde, com Platão, que o termo seria aplicado quase que exclusivamente no âmbito moral (1959, vol. I, 107), tornando-se em seguida um dos termos chaves do campo filosófico da ética. No Panegírico, embora ainda não houvesse tal especificidade em seu uso, aretē retinha esse sentido moral, designando não a virtude como uma qualidade moral genérica, mas apenas uma das virtudes, a coragem, virtude dos campos de batalha. Para preservar 
essa metonímia, optamos, em nossa versão do discurso, pela tradução mais usual do termo como virtude.

${ }^{32} \mathrm{Na}$ primeira parte do Panegírico, em que Isócrates propõe o domínio de Atenas, são utilizados diversos tópicos característicos dos epitaphioi, os discursos recitados no sepultamento público dos heróis de guerra em Atenas. Assim, a menção à autoctonia ateniense (23-25); as batalhas contra os trácios e amazonas (68-70) e o auxílio a Adrasto e aos heraclidas (54-56). O epitaphios era um gênero de discursos tipicamente ateniense, pois era parte de uma das ocasiões oficiais da polis (a cerimônia de sepultamento público). Uma prova adicional da importância desse discurso era a escolha do orador, feita pelo conselho, uma das instâncias de decisão política em Atenas (Plat. Men. 234b 4-10; Tuc. Hist. II, 34). Certamente, não é desprezível que o autor se utilize, em seu discurso, de tópicos tão marcadamente atenienses, relevando o caráter pró-ateniense de Isócrates no Panegírico.

33 A expressão "Dissensões internas" traduz staseis, o conflito entre cidadãos de uma mesma polis para tomar o poder.

34 No original grego, hetareiai. Desse modo se designavam grupos fechados de cidadãos, geralmente dos estratos mais ricos das poleis, que se organizavam em segredo e geralmente conspiravam para tomar o poder. Em Atenas, uma democracia, esses grupos eram identificados com um governo aristocrático ou oligárquico.

35 astu (plural: astē) designava o espaço urbano, sendo um conceito geográfico, enquanto polis era um termo de significado primordialmente político, designando determinada organização político. Para Maiores detalhes, vd. nota 13 a esta tradução (p. 99).

${ }^{36}$ Decidido a conquistar a Grécia, Xerxes ordena que se construam duas pontes no Bósforo, através das quais, por um sistema de cordas e polias, passavam-se as naus (Heród. Hist. VII, 22-24). Já na Europa, o rei ordenou que se construísse um canal pelo Monte Atos, que obstruía a passagem de seus exércitos (Heród. Hist. VII, 33-37). 
${ }^{37}$ De acordo com Heródoto, porém, a tentativa de aliciar os atenienses ocorreu após, e não antes da batalha de Salamina (VIII, 136).

${ }^{38}$ Salamina, uma ilha localizada cerca de $2 \mathrm{~km}$ a oeste do Pireu, foi o palco de uma das principais batalhas da Guerras Médicas, fundamental para a futura vitória dos gregos. Em 480 a.C., quando o rei persa Xerxes, que havia invadido a Grécia com suas tropas, estava prestes a atacar Atenas, os cidadãos decidem abandonar a polis, enviando as crianças, mulheres e velhos para Salamina, mas tripulando as naus com os homens para resistir aos persas. Todos os detalhes dessa batalha nos são relatados por Heródoto no Livro VIII (83-96) de suas Histórias.

${ }^{39}$ A casa ("oikos") era vista, pelos antigos gregos, como uma forma de organização social particular, sendo composta por diversos membros (os escravos, os filhos, a mulher...) em uma relação hierárquica cujo grau superior pertencia ao homem mais velho (“despotēs"). A casa, portanto, como forma de exercício do poder, constituía, para os cidadãos, uma educação política, pois aquele que organizava bem seus interesses domésticos, teria maior chance de ser um bom administrador dos bens públicos. Esse era um dos motivos por que, em Atenas, os sorteados para alguma função pública, tinham sua conduta como cidadãos avaliada, em um exame denominado dokimasia, o qual também considerava a gestão das questões domésticas como um dos critérios a permitir o acesso a um cargo público.

${ }^{40}$ A fundação de colônias, com efeito, era visto como um meio eficaz de diminuir as tensões internas da Grécia, enviando parte da população para terras distantes; ao mesmo tempo, a Ásia, possuindo terras férteis e sendo rica em recursos naturais, era cobiçada pelos gregos, que desejavam estender seu domínio a esse continente.

41 Decarquias eram juntas de dez homens, estabelecidas pelo estratego espartano Lisandro para controlar as poleis inimigas, após a vitória de Esparta na Guerra do Peloponeso. O governo das decarquias, no entanto, durou pouco, pois, devido a seus abusos contra os cidadãos (vd. nota abaixo), elas foram rechaçadas e Lisandro decidiu revogar seu poder. 
$\overline{42}$ Peltastas eram soldados de infantaria levemente armados, em oposição aos hoplitas, que portavam armaduras pesadas. Os primeiros peltastas eram de origem trácia, de forma que, ao utilizar essa palavra no parágrafo 115 para designar saqueadores das poleis, Isócrates pode estar se referindo a bárbaros. Para maiores detalhes, vd. Sage: 1996, p. 42.

${ }^{43}$ Jogo de palavras com archē, que designa tanto "início" quanto "comando".

${ }^{44}$ Os tratados e leis, na antiguidade, eram geralmente inscritos em pilares depositados em lugares com grande afluência de pessoas, como forma de tornar públicas suas decisões (cf. os parágrafos 176 e 180 deste discurso).

45 Referência ao conselho, ou boulē, que, na democracia ateniense, estava encarregado de estabelecer as questões que seriam votadas pelos cidadãos na assembleia. O conselho era composto por quinhentos membros, os prítanes (cinquenta membros para cada uma das dez tribos), dentre os quais se elegia um presidente (para maiores detalhes, vd. Aristót. Const. Aten. XLIII, 2-6). É evidente que, aqui, Isócrates deseja mostrar a inversão de valores que diz resultar do domínio dos espartanos, quando os cargos próprios da democracia ateniense são exercidos, todos ao mesmo tempo e sem a mediação de pares, pelo rei da Pérsia.

${ }^{46}$ Os espartanos estavam acostumados a governar entre servos, os chamados hilotas, originários da vizinha Messênia, e o fato de esses últimos também serem gregos naturalmente provocava acusações quanto à forma muito dura com que, em Esparta, eles eram tratados, suscitando assim o temor de um domínio espartano sobre a Grécia e de sua escravização pela Lacedemônia. Símbolo maior da violência dos espartanos para com os hilotas era o báculo ("baktēria"), insígnia carregada pelos oficiais e pelos reis. Como observou Hornblower, "a stick is not a proper weapon, but appropriate as a repressive device for coercing" (2011, p. 124-25), causando uma grande humilhação àquele que sofria seus golpes, e, portanto, sendo utilizado para inspirar medo nos servos. Por ser um instrumento de afirmação do poder senhorial sobre um escravo, daí decorre que brandir o báculo contra um homem livre era uma grande ofensa. Dessa forma, por duas ocasiões, 
oligarcas empossados pelos espartanos foram expulsos das poleis que governavam, pelos ultrajes contra seus cidadãos: Tucídides conta como o comandante espartano Astíoco quase foi linchado pela multidão de marinheiros siracusanos e túrios - homens livres, destacava o historiador -, após erguer o báculo contra um deles, Dorieu, em resposta às demandas por melhor pagamento (VIII, 84). Caso semelhante nos relata Plutarco, em sua Vida de Lisandro: após derrotar Atenas, o estratego espartano instalou, como comandante militar da acrópole, certo Calíbio; esse, porém, tendo brandido seu báculo contra Autólico, lutador ateniense, foi jogado ao chão por conta de seu desrespeito. Ao saber disso, Lisandro repreendeu Calíbio, dizendo-lhe que ele não sabia governar homens livres (Lis. 15, 7).

${ }^{47}$ Isócrates apresenta em seus textos sempre uma posição contrária à forma de governo de sua polis natal, embora, para não incorrer no ódio de seus cidadãos, o faça de forma velada; no Areopagítico, em que trata das questões internas de Atenas, o autor defende um maior poder ao Areópago, ou conselho (vd. nota acima), composto por uma pequena quantidade de representantes, em oposição à assembleia, instância máxima de decisão na polis, e que estava aberta a todos os cidadãos. Naturalmente, ao propor à restrição do número de participantes nas decisões públicas, Isócrates advogava uma política de contornos oligárquicos; o autor, porém, para não ser acusado por seus concidadãos, tem o cuidado de atacar a democracia de forma velada. Dessa forma, no Areopagítico, Isócrates diz não defender um governo oligárquico, mas a boa democracia, isto é, a democracia dos tempos de Sólon, mesmo se no tempo do antigo político Atenas não fosse uma democracia (20). Já no Panegírico, cujo elogio de Atenas é um dos eixos principais em que se estrutura o discurso, o autor não utiliza "democracia" para designar o governo de sua polis natal, preferindo usar o termo neutro politeia, que designa genericamente qualquer forma de governo.

${ }^{48}$ Hilota era o nome dado aos servos em Esparta. Eles não provinham, como geralmente acontecia nas demais poleis, de outras regiões da Grécia nem eram bárbaros, mas faziam parte de populações vivendo próximas à Esparta e que foram escravizadas pelos espartanos, sobretudo da Messênia, 
polis vizinha à Lacedemônia. Por esse motivo, a severidade com os espartanos costumavam tratar seus servos era notória entre os demais gregos.

49 Assim como "hilota", o termo "perieco" designava, na sociedade espartana, uma classe de cidadãos. Diferente dos hilotas, os periecos eram homens livres, embora não tivessem direitos políticos.

${ }^{50}$ A pobreza das Cíclades era bastante conhecida entre os gregos (vd. Heród. Hist. VIII, 111, sobre Andros, uma das ilhas do arquipélago), daí ser considerada cruel a política espartana de cobrar impostos de todos os territórios sobre seu comando.

${ }^{51}$ Quios era uma antiga aliada de Atenas, mas, após os atenienses empreenderem a campanha contra Sicília, Quios decidiu aliar-se a Esparta, que, com seu auxílio, pela primeira vez conseguiu derrotar a frota ateniense, tomando a supremacia marítima (vd. Tuc. Hist. VIII, 7).

${ }^{52}$ Evágoras, soberano de Salamina (a polis referida no parágrafo), havia conquistado quase toda a ilha de Chipre, antes de os vizinhos apelarem proteção ao rei da Pérsia, 390 a.C. Embora o Panegírico reserve ao monarca cipriota apenas essa breve referência, houve uma estreita relação entre esse personagem histórico e Isócrates (provavelmente agenciada pelo estratego Cônon, quando do seu exílio em Chipre; vd. nota 58 abaixo, p. 145). Assim, o autor dedicou um de seus discursos a Evágoras e outros dois a seu filho Nícocles, que foi um de seus alunos.

${ }^{53}$ Trata-se de Ciro, filho de Dario II, que, com a morte de seu pai, contestou a ascensão de seu irmão ao comando do império.

54 Parágrafo detalhando os sucessos das campanhas asiáticas dos espartanos, após seu desentendimento com o rei Artaxerxes II. Dercílidas era um almirante espartano, responsável pela conquista de Eólis, no noroeste da Ásia Menor, em 399 a.C., o qual encarregou seu subordinado, Drácon, da região vizinha, Atarneu (Xenof. Hel. III, 2, 1). Tíbron, por outro lado, teve menos sucesso e, após sua tentativa fracassada de tomar Larissa, os éforos de Esparta decidiram entregar sua posição a Dercílidas (Xenof. Hel. III, 1, 7). Agesilau II, por fim, um dos reis espartanos, foi um 
dos grandes defensores de uma política expansionista de Esparta no final do séc. V e início do séc. IV a.C.

55 Em 401 a.C., na batalha de Cunaxa, que opôs Artaxerxes a seu irmão Ciro, o Jovem. Este, reclamando o direito de governar, reuniu uma tropa de mercenários gregos, que, embora vitoriosa, viu-se obrigada a abandonar a luta, já que seu comandante fora morto em combate. Entre os membros da expedição grega estava Xenofonte, que relata a volta da tropa à Grécia na Anábase. É importante notar uma discordância entre os dois testemunhos: Xenofonte diz que seis mil foi o número de homens que chegaram à cidade grega de Lampsáco (Anáb. VII, 7, 33), mas que o contingente inicial que combateu o exército persa contava com 12.900 soldados (Anáb. I, 7, 10). Para maiores detalhes, vd. p. 29-30 do estudo introdutório.

${ }^{56} \mathrm{O}$ verbo aqui utilizado por Isócrates é paranomeō, significando, literalmente, "agir contra a lei" ou "agir contra o costume".

57 Sátrapas eram os governantes das províncias do império, e, embora estivessem submetidos à autoridade do rei, eles detinham grande poder dentro das regiões que controlavam.

${ }^{58}$ Cônon foi um estratego ateniense. Tendo participado da batalha nas Arginusas, em 406 a.C., ele foi o único dos comandantes a ser absolvido no processo subsequente (mesmo tendo conseguido a vitória para os atenienses, os comandantes foram levados ao tribunal por terem se recusado a recolher os corpos dos mortos). Após o fim da Guerra do Peloponeso, Cônon serviu aos persas, liderando sua frota contra a dos espartanos na batalha de Cnido, em 394 a.C., cuja derrota pôs um fim às pretensões de Esparta de controlar o mar. No fim de sua vida, o ateniense refugia-se em Chipre, sendo abrigado pelo rei Evágoras (que então se insurgia contra o rei Artaxerxes II da Pérsia; vd. o parágrafo 141 do Panegírico e a respectiva nota). A menção a Cônon no Panegírico é significativa, em virtude da sua proximidade com Isócrates: foi provavelmente por meio do estratego que Isócrates entrou em contato com a família real cipriota; ademais, o filho de Cônon não somente foi aluno de Isócrates, mas o autor a ele dedica uma extensa passagem da Antídose (101- 
39), por considerá-lo a maior prova do sucesso da educação por ele promovida, um general que, mesmo com poucos recursos, foi capaz de conseguir grandes vitórias para Atenas.

${ }^{59} \mathrm{O}$ general ateniense Temístocles foi um dos protagonistas nas Guerras Médicas. Tendo lutado em Maratona, ele convenceu os atenienses a reforçar sua frota, construindo 200 trirremes (Heród. Hist. VII, 140-5), fato decisivo para a vitória grega nas batalhas de Artemísio e Salamina. Após o fim da guerra, porém, Temístocles não conseguiu manter sua posição de preeminência em Atenas, vindo a ser exilado em 472 ou 471 a.C. Não conseguindo se estabelecer na Grécia, o general enfim vai à Ásia Menor, onde é acolhido pelo monarca Artaxerxes I, por ter aconselhado os comandantes gregos a não perseguir a frota persa além do Helesponto (Tuc. Hist. I, 137, 4), sendo-lhe atribuído o controle da Magnésia, província da Pérsia onde o grego termina seus dias, aproximadamente em 459 a.C. Para maiores detalhes sobre os dons ofertados pelos persas a Temístocles, vd. a Vida de Temístocles, de Plutarco (29).

${ }^{60}$ Isócrates omite que a destruição dos templos gregos pelos persas foi uma represália pelo incêndio do templo de Cibele, quando os jônios invadiram Sárdis.

${ }^{61}$ Este trecho do Panegírico remete ao "juramento de Plateia", feito pelos gregos antes da batalha contra os persas em 479 a.C. Conhecemos o texto desse juramento por meio de sua citação por Licurgo no Contra Leócrates (81) e por Diodóro Sículo (XI, 29, 3-4; Heródoto menciona o juramento em termos similares, embora não chegue a citar especificamente o que tenha sido dito naquela ocasião: VII, 132, 2).

${ }^{62}$ Eumolpidas e Cérices eram duas famílias, fundadas respectivamente pelas figuras mitológicas Eumolpo e Cérix, às quais estavam reservados os cargos de sacerdote nos mistérios eleusinos e nos cultos públicos. A primeira fornecia os líderes do culto - o hiērophantēs, ou alto sacerdote, enquanto à outra pertenciam o daduchos, que conduzia os iniciados carregando uma tocha - e o hierokēryx, ou núncio sagrado. É importante destacar que o sacerdócio era o único cargo hereditário 
em Atenas, não sendo concedido em sorteio, como a maioria das posições na polis, nem mediante voto, excepcionalmente usado na escolha dos estrategos.

${ }^{63}$ Os threnoi ("cantos fúnebres", como os traduzimos) eram composições cantadas em funerais. Alguns poucos fragmentos nos chegaram dessas canções, sob o nome de Simônides e Píndaro, mas a evidência é muito escassa para seja possível fazer qualquer generalização a seu respeito.

${ }^{64}$ Essa mesma expressão é retomada pelo orador Licurgo para se referir à poesia (Contra Leócrates 92).

${ }^{65}$ Outro nome para o príncipe troiano Páris, que, ao raptar Helena, provocou a guerra de Troia.

${ }^{66}$ Os discursos sobre fiança (parakatathēkē) visavam a recuperação da herança que fora confiada por um parente a um banqueiro. Esse tipo de discurso, de fato, é um exemplo perfeito para contrapor com os discursos de interesse público que Isócrates exalta seus leitores a praticar, pois as fianças eram questões privadas, de pouca importância para a polis ou para a Grécia em geral, o que era agravado pelo fato desse tipo de discurso centrar-se em assuntos financeiros. 


\section{Bibliografia}

1. Autores antigos (traduções, edições e comentários, organizados segundo o nome do editor)

\section{Alcidamante}

MuIR, J. V. (2001) Alcidamas: The Works and Fragments. Bristol: Bristol Classical Press.

\section{Aristóteles}

FreESE, John Henry. (1926) Art of Rhetoric. Cambridge, Massachusetts: Harvard University Press. (Loeb Classical Library)

IRWIN, Terence. (1999) Nichomachean Ethics. $2^{\text {nd }}$ ed. Indianapolis/Cambridge, Massachusetts: Hackett.

\section{Heródoto}

HudE, Carolus. (1908) Herodoti Historiae. Tomus prior (continens libros I-IV). Editio tertia. (Oxford Classical Texts)

\section{Homero}

THIEL, Helmut van. (2010) Homeri Ilias. Hildesheim/Zürich/New York: Georg Olms/Weidmann.

\section{Isócrates}

LACERDA, Ticiano Curvelo Estrela de. (2011) Contra os Sofistas $e$ Elogio de Helena de Isócrates: tradução, Estudo Introdutório e Notas. dissertação de mestrado. São Paulo: Universidade de São Paulo.

Mandilaras, Basilius G. Opera omnia. Vol. I-III. Monachii/Lipsiae: Saur 2003. (Bibliotheca scriptorum Graecorum et Romanorum Teubneriana.).

MATHIEU, G.; BRÉMOND, E. (trad. e ed.). Isocrate. 4 vol. Paris: Les Belles Lettres, 2003. (CUF)

NorLIN, George (trad. e org. vol. 1 \& 2); HooK, La Rue Van (trad. e org. vol. 3). Isocrates. Cambridge, Massachusetts: Harvard University Press, 1928 (vol. 1 \& 2), 1945 (vol. 3). (Loeb Classical Library)

PrIeto, Maria Helena de T. C. U. (1989) Politica e Ética: Textos de Isócrates. Lisboa: Presença. 
Rego, Júlio de Figueiredo Lopes. (2011) Os Discursos Cipriotas. Para Demônico, Para Nícocles, Nícocles e Evágoras, tradução, introdução e notas. dissertação de mestrado. São Paulo: Universidade de São Paulo.

SCHNEIDER, Otto. (1886) Isokrates ausgewählte Reden für den Schulgebraucht erklärt. Zweites Bändschen: Panegyrikos und Phillipos. Leipzig: Teubner.

UsHER, Stephen. (1990) Greek Orators III: Isocrates' Panegyricus and Ad Nicoclem. London: Aris \& Phillips.

\section{Lísias}

GeRnET, Louis; BIzos, Marcel. (1955). Lysias: Discours, Tome I. Paris: Belles Lettres. (2003) Lysias: Discours, Tome II. 5. ed. Paris: Belles Lettres.

ToDD, S. C. (2000) Lysias. Austin: University of Texas Press.

\section{Platão}

PlATo. (1995) Phaedrus. translated, with introduction and notes, by Alexander Nehamas and Paul Woodruff. Indianapolis/Cambridge, Massachusetts: Hackett.

BuRnetT, Ioannes. (1903) Opera Platonis Vol. III. Oxford: Clarendon. (Oxford Classical Library)

\section{Comentadores modernos}

Bandinelli, Ranuccio Bianchi. (1970) Rome: The Center of Power. 500 BC to AD 200. transl. by Peter Green. New York: George Braziller.

BLASS, Friedrich. (1874) Die attische Beredsamkeit. Zweiter Abtheilung: Isokrates und Isaios. Leipzig: Teubner.

. (1887) Die attische Beredsamkeit. Erste Abtheilung: von Gorgias bis zu Lysias. Zweite Auflage. Leipzig: Teubner.

BowIE, E. W. (1986) Early Greek Elegy, Symposium and Public Festival. Journal of Hellenic Studies, vol. 106, p. 13-35. 
BUCHNER, Edmund. (1958) Der Panegyrikos des Isokrates: Eine historisch-philologische Untersuchung. Wiesbaden: Franz Steiner.

BURKERT, Walter. (1984) Die orientalisierende Epoche in der grieschichen Religion und Literatur. Heidelberg: Carl Winter.

Colvin, Stephen. (2010) Greek Dialects in the Archaic and Classical Ages. In: BAKKer, Egbert J. $A$ Companion to the Ancient Greek Language. Oxford: Blackwell.

Chantraine, Pierre. (1977) Dictionnaire Étymologique de la Langue Grecque: Histoire des Mots. Quatre tomes. Paris: Klincksieck.

DAVIES, John. (2007) The Origins of the Festivals, especially Delphi and the Pythia. In: Hornblower, Simon; Morgan, Catherine. Pindar's Poetry, Patrons, and Festivals: From Archaic Greece to Roman Empire. Oxford: Oxford University Press, p. 47-69.

HeAth, Malcolm. (2003) Pseudo-Dionysius Art of Rhetoric 8-11: Figured Speech, Declamation, and Criticism. The American Journal of Philology, v. 124, n. 1, p. 81-105.

HeILBRUnN, Gunther. (1975) Isocrates on Rhetoric and Power. Hermes, n. 103, p. 154-78.

HoRnblower, Simon. (2011) The Greek World 479-323 B.C. 4. ed. Oxford/New York: Routledge. Instone, Stephen. (2007) Origins of the Olympics. In: Hornblower, Simon; Morgan, Catherine. Pindar's Poetry, Patrons, and Festivals: From Archaic Greece to Roman Empire. Oxford: Oxford University Press, p. 71-82.

JAEger, Werner. (2003) Paidéia: A Formação do Homem Grego. 4. ed. Trad. de Artur M. Parreira. São Paulo: Martins Fontes.

Kennedy, George. (1963) The Art of Persuasion in Greece. Princeton: Princeton University Press.

LATEINER, Donald. (1982) "The Man Who Does not Meddle in Politics": A Topos in Lysias. The Classical World, vol. 76, n. 1, p. 1-12.

MCKeChnIE, Paul; KeRn, S. J. (1988) Hellenika Oxyrhynchia. Warsminster: Aris \& Phillips. MASARACCHIA, Agostino. (1995) Isocrate: Retorica e Politica. Roma: GEI. 
ReEs, Roger. (2007) Panegyric. In: DominiK, William; Hall, Jon. A Companion to the Roman Rhetoric. Oxford: Blackwell.

SAGE, Michael M. (1996) Warfare in Ancient Greece: A Sourcebook. London/New York: Routledge.

SCHIAPPA, Edward. (1990) Did Plato Coin Rhetorike? The American Journal of Philology, vol. 111, n. 4 , p. 457-70.

. (1999) The Beginnings of Rhetorical Theory in Classical Greece. New Haven: Yale University Press.

USHER, Stephen. (1973) The Style of Isocrates. Bulletin of the Institute of Classical Studies, vol. 20, n. 1 , p. 39-67.

Wilamowitz-MoellendorfF, Ulrich von. (1985) Aristoteles und Athen. 3. unverändert Ausgabe. Zwei Bände. Zürich/Hildesheim: Weidmann. 